\author{
UNIVERSIDADE DE SÃO PAULO \\ FACULDADE DE FILOSOFIA, LETRAS E CIÊNCIAS HUMANAS \\ DEPTO DE FILOSOFIA - PROGRAMA DE PÓS-GRADUAÇÃO
}

\title{
A TRAMA E A URDIDURA \\ um ensaio sobre educação \\ a partir do Encantamento
}

\author{
Beatriz Machado
}

Versão corrigida da tese apresentada ao programa de Pós-Graduação em Filosofia do Departamento de Filosofia da Faculdade de Filosofia, Letras e Ciências Humanas da Universidade de São Paulo, para obtenção do título de Doutor em Filosofia sob a orientação da Profa. Dra. Marilena Chauí. 
RESUMO

Este trabalho recupera elementos do Sufismo - via mística originalmente islâmica -, notadamente da obra de Ibn 'Arabî, e busca inseri-los no contexto da sociedade e do pensamento atuais a fim de pensar as primeiras linhas de um modelo pedagógico voltado para a singularidade e a cidadania.

PALAVRAS-CHAVE

sufismo, Ibn 'Arabî, educação, pensamento analógico, encantamento.

\section{ABSTRACT}

The present paper brings back subjects found in Sufism, especially the works of Ibn 'Arabî, and tries to integrate them into the context of present society and contemporary thought, in order to sketch the first lines of a pedagogical model directed towards singularity and citizenship.

KEY WORDS

Sufism, Ibn 'Arabî, education, analogical thinking, Enchantment. 
para Cássia 


\section{Agradecimentos}

Este trabalho é resultado de pesquisas e experiências realizadas por Olga Elisa Castillo Modesto, querida amiga e parceira, e por mim a partir de 1986. O modelo pedagógico aqui utilizado é uma construção a 4 mãos e é, portanto, a ela, em primeiro lugar, que vai o meu mais profundo agradecimento.

Agradeço aos, simultaneamente, amigos, colegas e mestres, Alexandra Rodrigues Pinto, Cristina Ricardo, Judith Zuquim, Leda Torres, Fábio Ramazzina, Maria Cristina Kupfer, Sérgio Rizek, Rafael Haddock-Lobo, Ana Maria Continentino, Pablo Beneito, Olgária Matos, pelas conversas.

À turma da halka, pelo 'adab, ma'duba.

A Ana Lucia Moraes, que me fez ver a relação entre rives (margens) e rivalité.

Às minhas famílias, por sua misericordiosa paciência ao me liberar de meus deveres como filha, irmã, sobrinha, tia, esposa, madrasta, cuidadora da casa, dos cachorros, etc.

À Marilena, primeira intérprete da filosofia para mim, intérprete de minha linguagem indireta e minhas vozes em silêncio.

A Omar Ali Shah e Arif Ali Shah, shuyûh 


\section{ÍNDICE}

$\begin{array}{ll}\text { CODIFICAÇÕES E ABREVIAÇÕES } & 13\end{array}$

$\begin{array}{ll}\text { INTRODUÇÃO } & 17\end{array}$

$\begin{array}{ll}\text { PARTE 1: } & \text { O MUNDO ENCANTADO } \\ \end{array}$

$\begin{array}{ll}1.1 & \text { PRIMEIRA APROXIMAÇÃO - O CENÁRIO }\end{array}$

$\begin{array}{lll}1.2 & \text { SEGUNDA APROXIMAÇÃO - A HISTÓRIA } & 29\end{array}$

1.3 TERCEIRA APROXIMAÇÃO - OS CONCEITOS FILOSÓFICOS (UNIVERSALIDADE, SINGULARIDADE, TRANSCENDÊNCIA, IMANÊNCIA, UNIDADE, MULTIPLICIDADE, LEI SIMBÓLICA E LEI IMAGINÁRIA) 37

1.4 QUARTA APROXIMAÇÃO - O MUNDO DAS ANALOGIAS (AL-ALÂM AL-MIÎÂL) 47

1.5 QUINTA APROXIMAÇÃO - UMA NOÇÃO DE SUJEITO

$\begin{array}{ll}\text { PARTE 2: } & \text { PROBLEMAS DA SINGULARIDADE }\end{array}$

$\begin{array}{lll}2.1 & \text { ESPAÇO PÚBLICO E REVELAÇÃO } & 71\end{array}$

$\begin{array}{lll}2.2 & \text { ESPAÇO PÚBLICO COMO O ESPAÇO DA ESCRITA } & 77\end{array}$

$\begin{array}{lll}2.3 & \text { ESPAÇO PÚBLICO E IDENTIDADE } & 83\end{array}$

2.4 DUALIDADE COMO ESTRUTURA SIMBÓLICA NO MUNDO ENCANTADO 97

$\begin{array}{lll}2.5 & \text { UMA IDÉIA DE LUGAR } & 109\end{array}$

2.6 UMA CERTA CONCEPÇÃO DE POSIÇÃO IMAGINÁRIA 115

2.7 YOU AND THE LAND ARE ONE - ACERCA DAS HISTÓRIAS DE ENSINAMENTO 123

$\begin{array}{lll}2.8 & \text { A REALIDADE COMO LINGUAGEM } & 143\end{array}$

2.9 AUTONOMIA COMO ACOPLAMENTO COM A LEI 153

$\begin{array}{lll}2.10 & \text { RAZÃo ANALÓGICA, INTUIÇÃo ANALÓGICA } & 157\end{array}$

2.11 O SIMBÓLICO COMO ESTRUTURALIDADE

2.12 A CIÊNCIA DA CORTESIA ('ADAB) 185

2.12.1 AS ATRIBUIÇÕES DE SIGNIFICADO 192

2.13 O ESPAÇO PÚBLICO SIMBÓLICO

2.13.1 ESPAÇO PÚBLICO E MITO FUNDADOR 204 
3.1 "NÃO CRIAMOS EM VÃO O CÉU, A TERRA E O QUE EXISTE ENTRE ELES." (COR. 38:27) 213

3.1.1 O PENSAMENTO ANALÓGICO COMO ESTRUTURALIDADE

3.2 UMA TIPOLOGIA ENCANTADA: A ASTROLOGIA

3.2.1 O ZODÍACO COMO MODELO MENTAL

3.2.2 O ZODÍACO COMO FERRAMENTA ANALÍTICA 221

3.2.3 O ZODÍACO COMO FERRAMENTA IMAGINATIVA 222

3.3 ESTRUTURALIDADES DESENCANTADAS: META-PROGRAMAS E 6 CHAPÉUS 225

3.3.1 EXEMPLOS DE META-PROGRAMAS

3.3.2 OS 6 CHAPÉUS 227

3.4 O MODELO CALEIDOSCÓPIO - PRIMEIRA APROXIMAÇÃO 231

3.4.1 O TERMO DE REFERÊNCIA DA PESQUISA E INVESTIGAÇÃO

$\begin{array}{lll}\text { PARTE 4: } & \text { ANEXOS } & 235\end{array}$

$\begin{array}{lll}4.1 & \text { ANEXO 1 - SOBRE IBN 'ARABî } & 237\end{array}$

$\begin{array}{lll}4.2 & \text { ANEXO 2-HISTÓRIAS } & 241\end{array}$

$\begin{array}{lll}4.3 & \text { ANEXO 3-BIBLIOGRAFIA } & 257\end{array}$ 


\section{CODIFICAÇÕES}

\section{tabela de transliteração das letras árabes}

\begin{tabular}{|c|c|c|c|c|c|}
\hline 1 & $\hat{A}$ & $j$ & z & ق & $Q$ \\
\hline ب & $\mathrm{B}$ & س & $\mathrm{S}$ & ك & $\mathrm{K}$ \\
\hline ت & $\mathrm{T}$ & ش ش & $\mathrm{SH}$ & 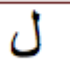 & L \\
\hline 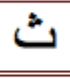 & $\underline{I}$ & ص & $\underline{\mathrm{S}}$ & r & $M$ \\
\hline ج & $\mathrm{J}$ & ضن & $\underline{\underline{D}}$ & $\dot{ن}$ & $\mathrm{~N}$ \\
\hline$\tau$ & $\underline{\mathrm{H}}$ & ط & $\underline{\underline{T}}$ & 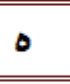 & $\mathrm{H}$ \\
\hline$\dot{c}$ & $\underline{\underline{\mathrm{H}}}$ & ظ & $\underline{z}$ & 9 & $0 / W$ \\
\hline د & $\mathrm{D}$ & $\varepsilon$ & ' & ي & $\hat{\imath} / \mathrm{Y}$ \\
\hline$j$ & $\underline{D}$ & $\dot{\varepsilon}$ & $\underline{\mathrm{G}}$ & 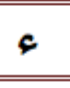 & " \\
\hline$\jmath$ & $\mathrm{R}$ & ف & $\mathrm{F}$ & & \\
\hline
\end{tabular}

\section{observações}

I- como think, no inglês.

$\underline{\mathrm{H}}$ - aspirado com o fundo da garganta, sem arranhar.

$\underline{\underline{\mathrm{H}}}$ - na garganta, como o "j" no espanhol.

$\underline{\underline{D}}$ - como no inglês "this".

$\underline{\mathrm{S}}$ - um "s" palatal.

$\underline{\underline{D}}$ - som enfático ("explosivo").

$\underline{\underline{T}}$-idem.

$\underline{Z}$-idem.

$\underline{\mathrm{G}}$ - na garganta, com um som próximo a um "r" gutural.

$\mathrm{Q}$ - som de $\underline{k}$ mas pronunciado com o fundo da garganta.

" - parada glotal (interrompe, faz um corte e volta).

$\mathrm{S}-\mathrm{um}$ "s" só tem som de "ss".

$\mathrm{R}$ - quando está duplicado tem som não como "carro", por exemplo, mas sim como se fôssemos ler a palavra "corte" se ela tivesse 2 "r": "corrte".

* - vogais em minúsculo: som muito breve, quase imperceptível.

* - os acentos circunflexos não indicam sílaba tônica, indicam a presença de alif ou das consoantes "u" e "i", o que alonga a pronúncia das letras. 


\section{ABREVIAÇÕES}

\begin{tabular}{|c|c|}
\hline Écrits & $\begin{array}{l}\text { Abd el-Kader, Écrits spirituels (trechos Kitâb al-Mawâqif), trad. Michel Chodkiewicz, } \\
\text { Éditions du Seuil, } 1982 .\end{array}$ \\
\hline Cor & Corão (Al-Qur'ân al-Karîm). Livro utilizado: tradução oficial da Meca para o francês. \\
\hline Secreto & $\begin{array}{l}\text { Ibn 'Arabî, El secreto de los nombres de Dios (Kashf al-ma'nà 'an sirr asmâ' Allâh al- } \\
\text { husnà), trad. Pablo Beneito, Ed. Regional de Murcia, España, } 1996 .\end{array}$ \\
\hline Parure & $\begin{array}{l}\text { Ibn 'Arabî, La Parure des Abdal (Hilyat Abdâl), trad. Michel Valsân, Les Éditions de l'O- } \\
\text { euvre, Paris, } 1992 .\end{array}$ \\
\hline Cercles & $\begin{array}{l}\text { Ibn 'Arabî, La Production des Cercles (Kitâb inshâ' al-dawâ'ir al-ihâtiyya), trad. Paul } \\
\text { Fenton e Maurice Gloton, Éditions de l'Éclat, Paris, } 1996 .\end{array}$ \\
\hline Sagesse & $\begin{array}{l}\text { Ibn 'Arabî, La Sagesse des Prophètes (trechos Fusus Hikam), trad. Titus Burckhardt, } \\
\text { Albin Michel, } 1974 .\end{array}$ \\
\hline Contemplaciones & $\begin{array}{l}\text { Ibn 'Arabî, Las Contemplaciones de los Misterios (Mashâhid al-Asrâr), trad. Suad } \\
\text { Hakim e Pablo Beneito, Editora Regional de Murcia, España, } 1994 .\end{array}$ \\
\hline Dévoilement & $\begin{array}{l}\text { Ibn 'Arabî, Le Dévoilement des Effets du Voyage (Kitâb al-isfâr 'an natâ'ij al-asfâr), } \\
\text { trad. Denis Gril, Éditions de l'Éclat, France, } 1994 .\end{array}$ \\
\hline Extinction & $\begin{array}{l}\text { Ibn 'Arabî, Le Livre de l'Extinction dans la Contemplation (Kitâb al-Fanâ'i fî-l- } \\
\text { Mushâhada), trad. Michel Vâlsan, Les Éditions de l'Oeuvre, Paris, } 1984 .\end{array}$ \\
\hline Chatons & $\begin{array}{l}\text { Ibn 'Arabî, Le Livre des Chatons des Sagesses (Kitâb Fusûs al-Hikam), trad. Charles- } \\
\text { André Gilis, } 2 \text { vols., Les Éditions Al-Bouraq, Beirute, Líbano, } 1998 .\end{array}$ \\
\hline Illuminations & $\begin{array}{l}\text { Ibn 'Arabî, Les Illuminations de la Mecque (trechos do Futûhât Makkiyya), trad. Chod- } \\
\text { kiewicz e outros, Albin Michel, Paris, } 1997 .\end{array}$ \\
\hline L'Interprète & $\begin{array}{l}\text { Ibn 'Arabî, L'Interprète des Désirs (Turjumân al-Ashwâq), trad. M. Gloton, Albin } \\
\text { Michel, } 1996 .\end{array}$ \\
\hline Le Sceau & Michel Chodkiewicz, Le Sceau des Saints, Gallimard, 1986. \\
\hline Océan & Michel Chodkiewicz, Un Océan sans rivage, Éditions du Seuil, 1992. \\
\hline Sentidos & Beatriz Machado, Sentidos do Caleidoscópio, Humanitas, 2004. \\
\hline
\end{tabular}




\section{INTRODUÇÃO}

Esta tese pretende ser a justificativa teórica da proposta de pesquisa e desenvolvimento de um modelo pedagógico batizado de Modelo Caleidoscópio.

A Partes 1 e 2 compõem uma primeira urdidura teórica do Modelo Caleidoscópio. A Parte 3 é constituída dos elementos que deverão compor a sua urdidura técnica.

O último capítulo consiste numa descrição sumária da idéia do Modelo.

Porque a tese trata, antes de tudo, de uma urdidura teórica, a Parte 3 encontra-se apenas esboçada. Seu maior desenvolvimento está, a princípio, condicionado à pesquisa que será proposta futuramente.

Com relação aos conceitos e termos de referência aqui trabalhados, o leitor deverá ter em mente que a maioria deles teve seus significados habituais transformados de modo a permitir a aproximação com o Mundo Encantado. Notadamente, o RSI, conceito psicanalítico lacaniano, foi inteiramente redesenhado, o que exigirá um esforço particular de atenção para as novas implicações que daí decorrem.

O contexto em que tal necessidade se apresenta é equivalente ao de um indío Tupinambá que, com a missão de explicar ao intrigado português a razão do canibalismo por ele professado, lhe assinalasse o costume "branco" de herdar os bens após a morte de um parente. Não há dúvida de que há certas semelhanças entre um costume e outro, contudo, torna-se crucial lembrar que as consequências de um e outro são, naturalmente, muito diferentes. 
Um dos aspectos de que mais gosto em Derrida é sua exigência de uma constante tomada de posição acerca de qualquer questão ${ }^{1}$. Lembro-me de uma conferência dada por Contardo Calligaris nos anos 90 em que ele mencionava algumas vicissitudes de sua adaptação ao Brasil: nosso hábito cultural, hoje ultrapassado entre jovens, de perguntar ao telefone "de onde fala?" fazia com ele se sacudisse cada vez que atendia uma ligação pois, ao encontrar-se naquele momento mergulhado em questões sobre o lugar de onde fala o sujeito do inconsciente, era como se a desconhecida pessoa do outro lado do fone o estivesse interpelando em sua mais profunda intimidade. Risos à parte, considero bastante ambiciosa a proposta sincera de ir em busca, o quanto possível, desse lugar particular de onde se fala de modo a falar em nome de um "eu" que não se dá a conhecer por suas boas notas na escola, seus insucessos amorosos ou suas preferências culinárias.

Tomar para si a responsabilidade não de dizer o que se pensa - bem republicano, virtude moderna - mas de pensar o que se diz, exercício reflexivo de espanto e submissão ao falante que nos silencia.

A aceitação do fato de que sou eu quem digo - e ninguém mais - exclui a possibilidade de uma neutralidade ou de uma distância seguras, assegura-nos Derrida. Ao mesmo tempo, encontro-me numa condição particular ao escolher trabalhar com a obra do Shay $\underline{\underline{h}}^{2} \mathrm{Ibn}$ 'Arabî, que nos diz que tudo o que encontramos em seus escritos provém de uma "insuflação divina", de um "ditado senhorial".

Alguns modernos tendem a significar tais afirmações como o sinal evidente de uma recusa da responsabilidade de homem atravessado pela castração, de homem não-todo, sujeito aos soluços do dizer. Um pouco de imaginação, porém, pode levar-nos na direção oposta: é brutal a responsabilidade de quem fala em Nome de Deus (bismillah).

Digo "imaginação" porque não há de ser improvável que as primeiras imagens que nos venham à mente ao ouvir esse bismillah é a de um homem-bomba, seguida daquelas hostes brancas da ku klux klan, ou de cardeais inquisidores, todos afirmando, de forma igualmente categórica, que falam em Nome de Deus. Mas é preciso ir além disso.

A frase que abre o livro do Corão, chamada de basmalah, pode traduzir-se do seguinte modo: "Em nome de Deus, o Misericordioso, o Misericordiador" ${ }^{3}$ (bismillah ar-rahman arrahim). No Islam, todo muçulmano repete a basmalah antes de começar qualquer ação.

\footnotetext{
${ }^{1}$ Digo isso em perfeita consciência de que muitos de seus críticos o acusam justamente do contrário.

${ }^{2}$ Em português, Sheik, lit = velho, título atribuído aos mestres espirituais do Sufismo. Pronuncia-se "chaih", sendo que este último "h" é aproximadamente como o som da letra "j" no espanhol.

${ }^{3}$ Utilizo a tradução do Prof. Helmi Nasr, tradutor do Corão para a língua portuguesa na tradução oficial da Meca.
} 
Qualquer muçulmano, de qualquer origem, em qualquer situação, fala e atua, segundo a Tradição, em Nome de Deus.

Claro está que não há de ser tampouco improvável que uma parte significativa dos muçulmanos da época atual pronuncie esta frase do modo mais automático e robótico possível. Ibn 'Arabî, porém, afirma que a realiza em sua plenitude.

A expressão em português "da boca para fora", designando aqueles que falam sem que seu corpo esteja implicado na fala, pode, inversamente, dar uma idéia da perspectiva do Shayh al-akbar (Ibn 'Arabî) ao dizer-se pertencente ao ahl al-dawq, o "povo dos que provam" (dos que sentem o gosto), a imaginação sendo o veículo por excelência da realização no corpo, a cada momento, desta nomeação (tasmiyya).

De minha parte, será convidando Merleau-Ponty a visitar o Profeta José, na esfera celeste de Vênus, que falarei desta encarnação do Nome de Deus pela via do Shay $\underline{\underline{h}}$.

A responsabilidade em questão, portanto, não pode ser jurídica, não quereria dizer responder pelas "consequências dos próprios atos", assim como não poderia ser defender uma posição contra outras. Ao contrário, falar em nome de Deus a partir do próprio corpo, vivo, há de ser falar hoje e desfalar amanhã, ou falar o "oposto" sem que isso signifique "irresponsabilidade". Perguntaram a Nasrudin: "Que idade você tem?", ele respondeu: "40". E eles disseram espantados: "Mas isso você disse dois anos atrás!" Ele respondeu: "Eu sou um homem de princípios".

Falar em Nome de Deus quer dizer permitir que a Palavra se diga, que a Escrita se pronuncie. Mas ela fala no corpo presente, no texto bruto daquele que necessita do oculto para mostrar-se. E reciprocamente. 


\title{
PARTE 1: O MUNDO ENCANTADO
}

\author{
Se queres iluminação especial, \\ olha o rosto humano: \\ vê, luminosa, em seu sorriso, \\ a essência da verdade suprema. \\ (Jallaluddin Rumi - séc. XIII)
}

Não te dei, ó Adão, nem rosto, nem um lugar que te seja próprio, nem qualquer dom particular, para que teu rosto, teu lugar e teus dons, os desejes, os conquistes e sejas tu mesmo a obtê-los. Existem na natureza outras espécies que obedecem a leis por mim estabelecidas. Mas tu, que não conheces qualquer limite, só mercê do teu arbítrio, em cujas mãos te coloquei, te defines a ti próprio... Ó suma liberdade de Deus Pai, ó suma e admirável felicidade do homem, ao qual é concedido obter o que deseja, ser aquilo que quer... Quem não admirará este camaleão?

(Pico della Mirandola - séc. XV) 


\subsection{PRIMEIRA APROXIMAÇÃO - O CENÁRIO}

Possivelmente, Max Weber, ao cunhar a expressão "desencantamento do mundo" para designar, em seu clássico "A ética protestante e o espírito do capitalismo", a especificidade e o ineditismo do racionalismo moderno frente ao "pensamento mágico" medieval, não supôs a amplitude que a idéia poderia alcançar.

Se podemos, hoje, utilizar a expressão "Mundo Encantado" para designar tudo o que foi antes do Desencantamento, isso não pode querer dizer que imaginamos ser possível identificar uma unidade - histórica, cultural, psicológica, etc. - nos homens que povoaram a Terra desde Adão até Descartes. No entanto, há, de fato, todo "um mundo" que o Período Moderno deixou para trás, não de forma abrupta, é óbvio, nem de forma absoluta, porém, de modo a encerrar no passado e eliminar da vida comum uma série de "realidades" humanas que, talvez, sob diversos aspectos, seria útil "recuperar".

Inicialmente, o que me proponho aqui é estudar um aspecto muito nítido e bem delineado do Encantamento: o Sufismo, uma via mística do Islam. E, especificamente, dentro do Sufismo, pretendo examinar elementos da obra de um mestre sufi, Ibn 'Arabî (séc. XIII, ver Anexo 1), que possam ser úteis para um pensamento sobre Educação nos tempos atuais.

Ao mesmo tempo, quero também reunir outros elementos, além do Sufismo, a fim de pensar um modelo pedagógico, objetivo último do presente trabalho. Dentre esses elementos, a crítica ideológica ocupa um lugar de destaque.

Para simplificar ao máximo a questão - e esta simplificação cumpre um objetivo filosófico e não didático -, quero estabelecer uma visão geral e bastante aberta do cenário em que pretendo me movimentar, e fazer ver os vastos campos que o compõem.

O Sufismo, a ideologia, o pensamento contemporâneo serão inicialmente tratados como, 
digamos, macro-realidades. O conceito marxista de ideologia, por exemplo, será alargado ao extremo a fim de servir a esta visão preliminar: pensarei a ideologia como o tecido que se interpõe entre o sujeito e a Lei simbólica, isto é, o conjunto dos processos conscientes e inconscientes de dominação, presentes na cultura - portanto, nos discursos em geral, seja do sujeito com ele mesmo, com os outros e com o mundo -, que obstaculizam a busca incessante de autonomia por parte do sujeito. Pela mesma via, a autonomia será aqui pensada como identificação integral com a Lei simbólica a partir da mística em geral e do Sufismo em particular. Finalmente, o pensamento contemporâneo cumprirá o papel de recortar o Sufismo, isto é, de torná-lo, por assim dizer, transmissível, na medida do possível, segundo os termos do modelo que pretendo construir.

De fato, se pensarmos o Sufismo como um "fenômeno datado", como uma prática possível exclusivamente dentro dos quadros da religião islâmica, enfim, como um saber isolado, não posso ver razão justificável para pensá-lo como referência para um modelo pedagógico. No entanto, como via mística, o Sufismo comporta essencialmente a crítica constante e perene aos procedimentos que levam os homens a criar limites ilusórios para si próprios e se eximir de suas responsabilidades perante os outros e o mundo. Nessa perspectiva, ele contém uma via de diálogo com a crítica ideológica que a potencializa e permite, como veremos, que ela também se transforme numa ferramenta pedagógica.

Ao mesmo tempo, o Sufismo - ou outras místicas como, por exempo, a Cabala -, como prática efetiva, e o Encantamento, como perspectiva, compreendem uma potencialização radical de todas as dimensões do homem e da cultura, o que envolve inúmeros problemas. Vejamos alguns.

Em primeiro lugar, o "conhecimento encantado" vê o homem inserido no Cosmos, não na Cultura nem na História, sendo que estas últimas também estariam inseridas no Cosmos, ou seja, é conhecimento de Deus e do Universo, portanto, de totalidades, o que, para o pensamento contemporâneo, é problemático. Vou trabalhar esta questão no decorrer desta tese.

Em segundo, o homem é análogo ao Cosmos e, portanto, todas as realidades interiores possuem as mesmas estruturas que qualquer realidade que se dê aos sentidos - nessa perspectiva, há uma possível aproximação entre o Mundo Encantado e o Pensamento Contemporâneo na medida em que este último, tendo superado dicotomias como sujeito e objeto, pode compreender o trânsito entre "realidades" pela via das teorias do discurso e da estruturalidade -, no entanto, enquanto a Filosofia "ocidental" oferece quase que exclusivamente à Psicanálise o estatuto de ciência da história individual do homem contemporâneo, o Mundo Encantado considera que todas as ciências encantadas são, igualmente, ciências da história individual porque são, em seu objetivo último, autoconhecimento e isso é precisamente o que poderia caracterizar - não sem que isso também acarrete inúmeros problemas - o Encantamento. Sem esquecer, naturalmente, que "ciência", "história individual" e "autoconhecimento" possuem no Mundo Encantado significação diversa da que hoje concebemos. Estas questões também serão discutidas ao longo do 
presente trabalho.

Em terceiro, as "práticas encantadas" - de operação simbólica - são incompreensíveis para nós, sobretudo os rituais que nos aparecem como "religiosos" (dentre os quais encontram-se, por exemplo, a repetição interior de palavras específicas, a leitura do Corão e, conforme o estágio de desenvolvimento do "estudante", a leitura de obras de mestres sufis) cujo objetivo é desenvolver no homem capacidades suprarracionais, isto é, no dizer de alguns místicos persas, torná-lo "capaz de Deus".

É verdade que grandes antropólogos esforçaram-se por interpretar gestos e palavras dos membros das mais variadas culturas indígenas ou africanas - e aqui refiro-me a estudiosos da estatura de um Lévi-Strauss, de um Pierre Clastres ou de um Leroi-Gourhand -, o que resultou em reflexão fundamental para o "nosso" tempo e a "nossa" cultura mas, somos forçados a admitir, que não substitui, muito menos abarca, o conhecimento que estes homens possuíam (e, em alguns casos, possuem) deles próprios.

Também é verdade que, de modo menos rigoroso, alguns cientistas esmeraram-se em colocar eletrodos no cérebro de "monges", "guias espirituais", etc., a fim de medir sua atividade cerebral durante uma meditação e disso tirar pífias conclusões, para dizer o mínimo. Certa vez, um psicanalista lacaniano comentou comigo que gostaria de me apresentar "um colega", pelo quê ele entendia alguém que tinha o mesmo "objeto de estudo" que eu e acrescentou: "seu último livro é sobre histeria e mística". Tratava-se da análise da biografia de uma "santa" francesa cujo nome já não tenho registrado. Li o livro conforme me foi solicitado, porém, não encontrei, em seguida, receptividade à crítica que me havia sido pedida. É evidente que o Desencantamento viu nascer "santas" e "santos" cujo comportamento buscava assemelhar-se ao máximo àquilo que supunham ser a Santidade, como um movimento próprio do Imaginário desencantado e que, nesse caso, é perfeitamente cabível buscar atravessar suas questões com o ferramental da estrutura da neurose. No entanto, a idéia de que a Psicanálise possa dar conta sozinha da Santidade de homens e mulheres que viveram no Encantamento corresponde a uma crença de universalidade que, ainda que compreensível, porquanto generalizada em tantas outras áreas do conhecimento moderno, é não menos insustentável. Para não falar das clássicas descrições da "hipocondria" de Teresa D'ávila e do sugestivo "ato falho" daqueles que, aludindo à famosa escultura de Bernini em que este descreve seu "êxtase", referem-se ao "orgasmo" de Santa Teresa; ou ainda do "caráter violento" de Muhammad, conforme as doutas assertivas do Imperador bizantino Manuel 2으, citado em recente conferência pelo Papa Bento 16, ou das associações novelescas dos relatos de encontros de lbn 'Arabî e seus mestres que viveram em outras épocas com a reencarnação de Alain Kardec. Os equívocos aqui são infindáveis.

Freud pôde construir uma teoria magnífica ilustrada por uma leitura de um mito grego, assim como Adorno pôde descrever o olhar burguês a partir da esperteza de Ulisses em amarrar-se no mastro do navio e tapar os ouvidos da tripulação. Do mesmo modo, Kierkegaard pôde pensar Abrahão como um "cavaleiro da fé diante do absurdo". Trata-se de lei- 
turas feitas sobre uma Escrita que possui muitas dimensões, sendo algumas delas, justamente, as que a tornam uma Escrita "encantada". Portanto, ainda que tais leituras tenham se mostrado bastante úteis para dar suporte às visões de cada autor, devemos ter em mente que elas podem não ter nada em comum com tais dimensões encantadas.

De qualquer modo, não temos, hoje, mais qualquer base epistemológica para considerar que as visões de Freud, Adorno, Kierkegaard ou qualquer um "de nós" sejam "mais verdadeiras" - menos ingênuas, mais racionais, mais científicas, etc. - que "as antigas". Ao contrário, já somos capazes de suspeitar que há algo no Mundo Encantado que nos escapa inteiramente. Deixo que Borges o diga a seu modo:

"O caso referiram-me no Texas, mas aconteceu noutro Estado. Conta com um só protagonista, salvo que em toda história os protagonistas sejam milhares, visíveis e invisíveis, vivos e mortos. Chamava-se, creio, Fred Murdock. Era alto à maneira americana, nem louro nem moreno, de perfil de machado, de não muitas palavras. Nada singular havia nele, nem sequer essa fingida singularidade que é própria dos jovens. Naturalmente respeitoso, não descria dos livros nem dos que escrevem os livros. Sua era essa idade em que o homem não sabe ainda quem é e está disposto a se entregar ao que lhe propõe a sorte: a mística do persa ou a desconhecida origem do húngaro, as aventuras da guerra ou da álgebra, o puritanismo ou a orgia. Na universidade aconselharam-lhe o estudo das línguas indígenas. Há ritos esotéricos que perduram em certas tribos do oeste; seu professor, um homem idoso, propôs-lhe que fizesse sua morada num acampamento, que observasse os ritos e que descobrisse o segredo que os feiticeiros revelam ao iniciado. Na volta, redigiria uma tese que as autoridades do instituto dariam a lume. Murdock aceitou com alacridade. Um de seus antecepassados morrera nas guerras da fronteira; essa antiga discórdia de suas estirpes era agora um vínculo. Previu, sem dúvida, as dificuldades que o aguardavam; tinha que conseguir que os homens vermelhos o acolhessem como um dos seus. Empreendeu a longa aventura. Mais de dois anos viveu na pradaria, sob toldos de couro ou à intempérie. Levantava-se antes da aurora, deitava-se ao anoitecer, chegou a sonhar num idioma que não era o de seus pais. Habituou seu paladar a sabores ásperos, cobriu-se com roupas estranhas, esqueceu os amigos e a cidade, chegou a pensar de uma maneira que sua lógica refutava. Durante os primeiros meses de aprendizagem, tomava notas sigilosas, que rasgaria depois, talvez para não despertar a suspicácia dos outros, talvez porque já não precisasse delas. Ao término de um prazo prefixado por certos exercícios, de índole moral e de índole física, o sacerdote ordenou-lhe que fosse recordando seus sonhos e que Ihos confiasse ao clarear o dia. Comprovou que nas noites de lua cheia sonhava com bisontes. Confiou estes sonhos repetidos a seu mestre; este acabou por revelar-Ihe sua doutrina secreta. Uma manhã, sem despedir-se de ninguém, Murdock se foi.

$\mathrm{Na}$ cidade, sentiu saudades daquelas tardes iniciais da planície em que sentira, fazia tempo, saudades da cidade. Encaminhou-se ao gabinete do professor e lhe disse que sabia o segredo e que resolvera não publicá-lo. 
- Seu juramento o impede? - perguntou o outro.

- Essa não é minha razão - falou Murdock. - Naquelas lonjuras aprendi algo que não posso dizer.

- Talvez o idioma inglês seja insuficiente? - observou o outro.

- Nada disso, senhor. Agora que possuo o segredo, poderia enunciá-lo de cem modos distintos e ainda contraditórios. Não sei muito bem como dizer-lhe que o segredo é precioso e que agora a ciência, nossa ciência, parece-me uma simples frivolidade.

Acrescentou ao fim de uma pausa:

- O segredo, ademais, não vale o que valem os caminhos que a ele me conduziram. Esses caminhos há que andá-los.

O professor falou-lhe com frieza:

- Comunicarei sua decisão ao Conselho. O senhor pensa viver entre os índios?

Murdock respondeu-lhe:

- Não. talvez não volte à pradaria. O que me ensinaram seus homens vale para qualquer lugar e para qualquer circunstância.

Tal foi, em essência, o diálogo.

Fred casou-se, divorciou-se e é agora um dos bibliotecários de Yale." ${ }^{4}$

\footnotetext{
4 Jorge Luis Borges, "O Etnógrafo", in Elogio da Sombra, Editora Globo, 1977.
} 


\subsection{SEGUNDA APROXIMAÇÃO - A HISTÓRIA}

O Sufismo não é uma escola, nem uma filosofia, nem uma doutrina, nem uma religião. A lista dos mestres sufis que citarei ao longo deste trabalho cobre todo o período que vai do Profeta Muhammad até os autores sufis contemporâneos. Difícil, portanto, encerrá-lo dentro dos limites do Mundo Encantado: o mais apropriado seria, talvez, dizer que $o$ Sufismo é justamente o que, hoje, tendo atravessado incólume as barreiras impostas pelo Desencantamento, possui os operadores de leitura que nos facultariam o acesso ao Encantamento de um modo que o renovasse e o traduzisse para este momento. Também seria importante assinalar que o Sufismo e a Mística em geral correspondem à dimensão mais radical e mais sofisticada do Encantamento, o que é o mesmo que dizer que este, no que se refere ao "comum dos homens", é claramente mais limitado que aquele.

Tais afirmações, no entanto, são problemáticas e exigem uma longa discussão. Não a farei, porém, num tópico específico, pois ela se encontra entremeada aos materiais básicos da construção a que me proponho.

Se considerarmos, por exemplo, a obra de um sufi contemporâneo como Idries Shah (m. 1995), vemos que ela tanto nos remete à ambiance espiritual de mestres sufis que viveram dentro do Dar al-Islam, isto é, a algo pertencente a "outra" época e a "outra" cultura, quanto nos coloca diante de um Sufismo inteiramente atual e "ocidental", no sentido de que discute temas da ciência e da filosofia a partir, digamos, de uma perspectiva sufi.

Idries Shah não apenas apresenta o Sufismo e prepara o leitor para seguir a via sufi mas também desenvolve um trabalho para além do círculo prático e técnico do "Povo do Segredo". Ou seja, o ensinamento sufi possui inúmeras formas e seria ignorância pura e simples procurar encerrá-lo no âmbito exclusivo da confraria. Não obstante, esse ensinamento, mesmo em sua forma mais acessível, tampouco pode ser considerado como uma transmissão de idéias, no sentido que essa expressão teria para "nós, ocidentais contemporâneos". O Sufismo não trabalha com conceitos e não há como reproduzir aqui o 
pensamento, ou "as idéias", ou "as crenças" de Shah ou de qualquer sufi. Não se trata propriamente de algo que se deva estranhar, já que, por exemplo, um filósofo contemporâneo como Derrida, tampouco pretende trabalhar com conceitos, no entanto, há aspectos desse ensinamento que diferem do trabalho racional de qualquer pensador ocidental atual.

Não pretendo discutir a fundo tais aspectos pois meu objetivo reside em trabalhar justamente com a dimensão racional e, por assim dizer, racionalmente transmissível das obras dos mestres sufis aqui citados. O motivo disso deveria ser óbvio: somente um mestre sufi tem acesso a essa outra dimensão.

Não obstante, a vasta obra de Ibn 'Arabî, por exemplo, exige um mergulho no "oceano sem margem" do Mundo Encantado, o que, por si só, já constitui tarefa de grande porte. Termos como "amor", "interioridade", "Deus", "revelação", entre tantos outros, antes símbolos, hoje são palavras-clichê, impermeáveis a qualquer aproximação por parte de um sujeito em sua singularidade. O enfrentamento desta questão compreende boa parte do presente trabalho.

Diferentemente de muitas outras formas do "Mundo encantado", o Sufismo também possui, além de interlocutores vivos, uma documentação extensa e confiável. Assim, em linhas gerais, utilizo o termo "mística" para designar uma espécie de "encantamento lato sensu", no qual incluem-se povos e épocas diversos, para afirmar que não se trata "apenas" de uma perspectiva sufi. Mais especificamente, a "Mística" por excelência refere-se aos místicos da Tradição Abrahâmica - Judaísmo, Cristianismo e Islam. Não obstante, mestres do Taoísmo, do Budismo ou do Hinduísmo também podem ser chamados de místicos. Por outro lado, é a perspectiva sufi, com toda a sua especificidade, que me fornece os materiais e a condição de um trabalho rigoroso e documentado.

Um dos problemas a serem resolvidos reside no fato de que todos esses termos - mística, esoterismo, espiritualidade, etc. - ganharam significados muito diferentes, e por vezes opostos, daqueles intencionados pelos sufis. Nesse sentido, "mundo encantado" e "encantamento", mesmo com todas as dificuldades que apresentam, constituem uma vantagem por estarem desprovidos dessas distorções.

Por outro lado, a idéia atual de "encantamento" possui, de sua parte, uma aura de romantismo e de idealização que nos coloca o risco do preconceito inverso: o de aceitarmos a perspectiva sufi como uma alternativa bela, mágica e salvadora oposta às frustrações do racionalismo. Frustração bem maior é a que espera aquele que se ponha neste lugar. Pelo menos dois tipos de advertência são importantes aqui.

Em primeiro lugar, o Mundo Encantado em geral e o Sufismo em particular constituem não apenas um vasto campo de estudo e de investigação mas também, no aspecto que agora passo a focalizar, uma perspectiva radicalmente diferente da que estamos habituados. 
Por um lado, desde as nossas idéias a respeito do que é conhecimento e para quê ele serve, até os meios que utilizamos para obtê-lo e para transmiti-lo, tudo isso difere nos mundos encantado e desencantado. Apenas para dar um exemplo muito suscinto, no Mundo Encantado há duas vidas: a presente e a futura. A futura consiste na vida após a morte.

No Mundo Desencantado, seja ele moderno ou contemporâneo, seja na filosofia ou na ciência, a possibilidade de se falar em vida após a morte encontra-se rigorosamente circunscrita às religiões (onde se inclui, obviamente, o Espiritismo, inventado por Alain Kardec no século XIX, e suas formas correlatas subsequentes).

No Mundo Encantado, todas as formas de conhecimento - das artes aos rituais, da vida cotidiana à contemplação, da sexualidade à medicina, das ciências à jurisprudência, etc. não apenas trabalham nestes dois campos como operam a partir da perspectiva de que se trata, na realidade, de um único campo real, cuja divisão é, antes de tudo, um modo de olhar. E a maneira técnica com que esta questão é tratada, sendo rigorosamente diferente tanto da religiosa quanto da do Espiritismo em todas as suas formas, nos coloca diante da magnitude da distância que separa os nossos hábitos mentais contemporâneos das formas do conhecimento encantado. Não há como tratar esta questão como um detalhe. Tampouco como uma incômoda fantasia "primitiva", posta como um "mecanismo de defesa" contra o que nos parece algo como uma "angústia do desconhecido" e um "medo natural da morte". Com respeito a este tema, bem como a muitos outros do Mundo Encantado, o desconhecimento é exclusivamente nosso e fazer o mínimo é adentrar este Mundo como um respeitoso cidadão estrangeiro, não como um vulgar conquistador.

Em segundo lugar, com o Sufismo, como se não bastassem as referências constantes a Deus, seremos colocados diante do Corão, do profeta Muhammad, dos outros profetas tas como Jesus, Moisés, Abrahão. Ouviremos falar de Maria, mãe de Jesus, da esposa do Faraó, que acolheu Moisés, de Fátima, filha do Profeta do Islam. Igualmente, mencionaremos o Islam, o Cristianismo, Judaísmo, por exemplo, num esforço incrível para resgatar a dimensão simbólica - e, portanto, técnica - destes termos. E, para que tenham a sua possível, digamos, eficácia simbólica ${ }^{5}$, é preciso que haja, de nossa parte, um mergulho na ambiance histórica em que eles foram alçados à condição de símbolos e, em seguida, um abandono dessa identificação a um período histórico e sua devida "tradução" para o tempo, o lugar e as pessoas de hoje.

Não há como negar a estranheza de todo esse universo. Aos poucos, porém, o que se espera é que o Encantamento comece a dizer-se de modo genuíno e a mostrar suas razões. Nem magia, nem preenchimento, mas, ao contrário, de grande capacidade de esvaziamento é feita esta travessia.

Como realidade histórica, o Mundo Encantado é uma realidade perdida ${ }^{6}$. Como História,

\footnotetext{
${ }^{5}$ Não apenas no sentido de Lévi-Strauss.

${ }^{6}$ Pode-se objetar que o Encantamento continua vivo em muitas formas de cultura popular, sobretudo no
} 
no entanto, ele é outra coisa. E é desse modo que pretendo abordá-lo.

Nesse caso, seria forçoso admitir que, se, por exemplo, um homem medieval alega acreditar em elfos, não podemos simplesmente considerar que ele possua o mesmo grau de ingenuidade que um cidadão de hoje que dissesse a mesma coisa, pois, no Mundo Encantado, os elfos correspondem a um tipo de simbolismo, isto é, a um tipo de sabedoria. No entanto, no mesmo período medieval, podemos encontrar um outro homem, talvez um vizinho, um irmão ou um colega de ofício do primeiro, que, ao fazer a mesma alegação, seja igualmente um ingênuo supersticioso pois, com toda a evidência, nem todos os homens possuem o mesmo grau de conhecimento. Desse modo, há aspectos desta sabedoria que se encontram restritos a certos grupos e outros que se encontram, por assim dizer, disseminados.

Seria um equívoco, no entanto, tratar o Encantamento como uma ciência oculta ou esotérica - no sentido moderno do termo - e supor que um comerciante do mercado de Istambul, ao ouvir um contador de histórias na praça contando uma história de Nasrudin, não seja capaz de captar sutilezas que os doutos do nosso tempo sequer compreenderiam. Ao contrário, houve épocas em que um mendigo teria mais conhecimento de ciência do Mundo Encantado que o ganhador de um Nobel teria de ciência desencantada ${ }^{7}$.

Assim, no campo de reflexão que estou agora construindo, o Encantamento não se refere a uma época ou a um lugar ou a um povo presente homogeneamente na História. Ele é uma perspectiva.

Claro está que podemos dizer que o Encantamento é um acontecimento comum a certos grupos humanos, em certos momentos e lugares da História. Desse modo, haveria algo em comum entre um certo pajé e um certo mestre taoísta, ou hassídico ${ }^{8}$, ou budista, ou sufi ou iorubá.

Schuon cunhou a expressão "unidade transcendente das religiões" ${ }^{9}$ para referir-se a esse algo em comum. Michel Valsân fez ver o perigo de que esta idéia se torne, pelo uso descuidado, uma abstração na qual sejam perdidas as especifidades fundamentais de cada "religião", isto é, de cada grupo humano em que essa unidade possa ser visível ${ }^{10}$.

Em busca de precisão, considero que a expressão de Schuon, fundamental para abrir, nos

\footnotetext{
chamado Terceiro Mundo. A meu ver, é verdade que, para citar um único exemplo, em muitas danças folclóricas em diversas partes do mundo, podemos encontrar elementos ritualísticos - portanto, que envolvem técnicas de concentração, relaxamento, autoobservação, meditação, reequilíbrio, cura ou abertura para um contato profundo de cada um consigo mesmo - no entanto, o quanto desses elementos cumpre integralmente ou apenas de modo fragmentado a sua função original é algo a ser discutido caso a caso.

${ }^{7}$ Esta afirmação deverá esperar o necessário desenvolvimento das idéias que aqui apenas se esboçam para ser melhor explicada e explicitada.

${ }^{8}$ Tradição judaica.

${ }^{9}$ citar o livro.

${ }^{10}$ citar o artigo.
} 
anos 60, um caminho na direção de um resgate do Encantamento, torna-se, hoje, problemática. Em primeiro lugar, porque não se trata exclusivamente de transcendência. Em segundo, porque não se trata exclusivamente de religiões. E é nesse contexto que podemos vislumbrar a importância da observação de Valsân.

Ao experimentar o Encantamento, cada grupo humano, a cada momento, o faz de um modo único e singular porque o Encantamento consiste fundamentalmente no exercício da Singularidade. Em outras palavras, cada grupo de homens e cada homem em particular tem a possibilidade de tomar para si o patrimônio de conhecimento herdado de outros tempos e fazer algo de inteiramente novo e único. Se assim é, como falar em algo comum que permita abrigar todas essas singularidades sob o mesmo guarda-chuva e chamá-lo de Encantamento, como se houvesse um fenômeno, ou um conhecimento ou uma mesma idéia ou, em termos hegelianos, um Espírito acima delas?

"O sufismo (tasawwuf) é hoje um nome sem realidade enquanto que, antes, era uma realidade sem nome", anunciava admoestativamente, já no século XI, Hujwîrî, um importante mestre sufi do Afganistão ${ }^{11}$. Não obstante, a "realidade sem nome" continua sendo praticada e, mesmo depois de tanto tempo transcorrido entre a primeira revelação corânica e os dias de hoje, os sufis - não por acaso este é o título de um dos livros de Idries Shah - continuam reconhecendo-se entre si, independentemente do nome que sua atividade possua. É exatamente desse mesmo modo que, aqui, o termo "Encantamento" deveria ser utilizado: para referir-se, antes de tudo, a uma realidade sem nome.

Se podemos admitir a comunhão entre Teresa d'Avila, Bernardo de Claraval, Ibn 'Arabî, Dante Alighieri, Miguel de Cervantes, Rumi, Baal Shem Tov ${ }^{12}$, Nachman de Bratslav ${ }^{13}$, Jesus, Buda, um padre do deserto, um pajé americano, um índio brasileiro (ambos, evidentemente, antes do contato com "o homem branco"), Moisés e Muhammad, não podemos admitir, sob pena de perder completamente de vista essa comunhão, que se possa encontrar nela uma doutrina única, uma verdade a-histórica, um objetivo comum, uma definição particular. Por outro lado, dizer que cada "atividade encantada" seria histórica a partir de uma visão linear da História - em que esta é definida como um progresso positivo e gradativo do conhecimento - o que nos constrangeria a ler uma fala do Rabi Zus$\mathrm{sia}^{14}$ ou de Dul Nun Misri ${ }^{15}$ como circunscrita "à sua própria época", seria, à luz da vasta documentação de que dispomos hoje e das inúmeras críticas, por exemplo, ao etnocentrismo moderno, uma prova de ignorância ou de má fé. Tampouco uma História pensada como sucessivas manifestações do Espírito a cada época poderia nos salvar: a sentença "Deus é Um" (Allahu Ahad), proferida por Abrahão, por Muhammad ou por Ibn 'Arabî não

\footnotetext{
${ }^{11}$ Se, naquele momento, tratava-se de alertar os iniciantes quanto ao perigo de uma prática superficial, hoje o "nome sem realidade" pode igualmente designar os "sufis da moda", espalhados entre a Índia e a Califórnia, gozando de crescente apreço na "classe média globalizada", segundo a feliz expressão cunhada, até onde sei, por Gregório, personagem do filme "Conversando com Mamãe", de Ulises Dumont.

12 "Fundador" do Hassidismo, via mística judaica.

${ }^{13}$ Mestre hassídico.

${ }^{14}$ Mestre hassídico.

${ }^{15}$ Mestre sufi.
} 
configura uma época - ela é a mesma através das épocas, a sentença, não o seu espírito e, para anunciar uma formulação com ares de encantamento, ela só possui "sentido verdadeiro" se for ouvida não como exclusivamente "de Abrahão" mas, sim, igualmente como daquele que acaba de escutá-la.

Nesse sentido, há um aspecto do Encantamento perante o qual qualquer consideração de ordem histórica representa uma mutilação. Isso não quer dizer que devamos postular um antagonismo entre Encantamento e História, ou que seja necessário supor uma ordem acima da História. Ao contrário, entre ambos há harmonia, portanto, proximidade e distância.

De certo modo, o que espero que possa ser sustentado ao final do presente trabalho é que, se e a História não é o bastante para definir diferenças entre os diversos tipos de "Encantamento" e, com esse procedimento, estabelecer um denominador comum que nos permita unificá-los sob a égide de um "Mundo Encantado", tampouco outras Ciências Humanas podem resolver nosso problema. Qualquer meio que utilizemos para definir o que há de comum entre uma santa sufi como Rabia al-Adawwiya e um velho índio amazonense, digamos, do século $X$ nos levará ou a um reducionismo ou à constatação de uma impossibilidade.

Dito de outro modo, podemos dizer que o Conhecimento, no Mundo Encantado, é o que se obtém por meio do desenvolvimento de faculdades especiais que ultrapassam ou se distinguem do domínio da razão. Com certeza, não se trata de uma negação da razão mas, sim, de um tratamento sobre ela que a torna diferente da "nossa razão". No entanto, se buscarmos definir quais são essas faculdades especiais e que Conhecimento é esse, mais uma vez seremos colocados diante de uma tamanha diversidade que nosso esforço resultará apenas em mais perplexidade. É como se um biólogo chegasse num outro planeta e descobrisse uma natureza inclassificável.

De um outro ponto de vista, a pluralidade do mundo encantado não o torna inapreensível:

Alguém reclamou com um sábio sufi que as histórias que ele contava eram interpretadas de uma maneira por uns e de outra por outros.

- É precisamente o que faz o seu valor, disse o sábio. Que caso faria você de um copo no qual se pudesse beber leite mas não água, de um prato no qual se pudesse comer carne mas não frutas? Copo e prato são recipientes limitados. A linguagem, não deveria ela ser infinitamente mais capaz de fornecer alimento? A questão não é: "de quantas maneiras posso compreender isto e por que é que eu não posso vê-lo de uma única maneira?" A questão é antes: "tal indivíduo, poderia ele tirar proveito daquilo que encontra nas histórias?"16

Do mesmo modo, no pensamento contemporâneo, a diversidade das interpretações e das

\footnotetext{
${ }^{16}$ Idries Shah, Sages d'Orient, Ed. du Rocher, 1988, p. 48.
} 
visões não só não é um problema, como é uma abertura:

Esperamos também que a multiplicidade de filosofias e interpretações deixe de ser encarada como limitação e dispersão e como impossibilidade do verdadeiro para ser concebida como riqueza inesgotável do pensamento para pensar o que não foi pensado e para dar a pensar, generosidade e relação com o verdadeiro como horizonte. ${ }^{17}$

Na perspectiva que busco construir, se a História não for considerada como uma ciência positivista moderna e sim como um modo de transmissão simbólica, a "diversidade encantada" não será unificada nem homogeneizada sob um conceito mas será experimentada como uma rede de conexões neurais, isto é, que se fazem e se desfazem a cada momento. E essa é uma aproximação de uma visão encantada da História.

Uma história encantada é a que toma o passado como uma silsillah, nome técnico utilizado nas confrarias sufis para designar a cadeia de transmissão entre os mestres que "abrem a porta" aos discípulos. Nesse sentido, há história mas não há passado: o mestre está sempre vivo já que ele morreu antes de morrer $^{18}$.

Portanto, no contexto presente, o Mundo Encantado é igualmente uma realidade sem nome, uma realidade inomeável e uma realidade a ser permanentemente renomeada por todo aquele que se dê ao paciente trabalho de fazê-lo e refazê-lo a cada instante.

\footnotetext{
${ }^{17}$ Marilena Chauí, É possível uma história da filosofia?, curso de pós-graduação na USP, 2010.

${ }^{18}$ Alusão a uma fala do Profeta: "Morram antes de morrer e prestem a vocês mesmos contas antes que elas Ihes sejam pedidas".
} 


\subsection{TERCEIRA APROXIMAÇÃO - OS CONCEITOS FILOSÓFICOS (UNIVERSALIDADE, SINGULARIDADE, TRANSCENDÊNCIA, IMANÊNCIA, UNIDADE, MULTIPLICIDADE, LEI SIM- BÓLICA E LEI IMAGINÁRIA)}

Não se pode, a rigor, falar em conceitos no Sufismo. Instrumentos da Filosofia e não da Mística, eles aqui são apenas uma tradução filosófica do universo sufi.

Muhammad foi enviado "a todos" (Corão, 7:158). Para Ibn 'Arabî, este verso implica que a mensagem corânica dirige-se não somente aos que professam afirmativamente a religião muçulmana, mas a todos os homens, inclusive os que viveram antes do nascimento do Enviado de Allah.

Seria, no entanto, inadequado, ver nesta consideração a idéia de uma universalidade do Livro, no sentido que o termo adquiriu na Modernidade. Não se trata aqui do pressuposto de que a Revelação islâmica seria igualmente válida - ou obrigatória - para qualquer um, a ser imposta sobre "os infiéis" pela violência do discurso ou da força.

Ao contrário, mesmo um exame superficial da obra de Ibn 'Arabî pode facilmente revelar que o que está em jogo aqui não é o universal e sim o singular - que, vale estabelecer, é diferente do particular ou do individual. Há uma característica fundamental nesta Escrita que faz com que ela esteja endereçada a cada homem em sua unicidade. E, precisão necessária, não exatamente a cada homem em sua identidade, ou em sua essência: para cada homem, a cada momento, o verso corânico possui um significado diferente.

Nenhuma criatura, homem, planta ou animal, possui o que hoje entenderíamos por identidade ou essência. A criação não está "fixada" em definições, não há nada "em si" ou "por si". O homem não é um conjunto de características imutáveis, ele não possui um ponto de partida único, "pessoal e instranferível", tampouco possui um ponto de chegada. O termo "unicidade" aponta para uma distinção entre os homens, há uma diferença entre cada homem e os outros, cada um encontra-se num lugar e num tempo específicos, ninguém é, todos estão. 
Fora de seu contexto, seria difícil dizer se o parágrafo acima é contemporâneo ou encantado. A rigor, ele cabe perfeitamente na perspectiva de ambos, o que, a meu ver, pode servir como justificativa para as relações que pretendo estabelecer.

Dizer que a Escrita é universal-singular é dizer que ela toma, historicamente, formas e formatos diferentes ao mesmo tempo em que se relaciona com cada um - homem, sujeito, pessoa, alguém - de um modo único.

As galáxias, os anjos, os perfumes, as formigas, as noites, as abstrações, as tristezas e as modificações, não sendo, de modo algum, coisas em si, são inscrições em movimento. Para "nós, ocidentais modernos", há sociedades ágrafas. Para estes homens, não. Nunca houve gente sem escrita. Pinturas rupestres, vasos, escrita no corpo, roupas, canto, dança, êxtase, medo e escuta, tudo isso é escrita porque é exercício de singularidade. Um homem medieval, como o jovem Percival, poderia acreditar que o mundo não era maior que a distância percorrida em 20 dias, mas havia homens medievais para quem o mundo era do tamanho do seu próprio corpo, ou seja, infinito. Quando Ibn 'Arabî nos diz que o universo, o Corão e o homem perfeito (al-insân al-kamil) são "irmãos", "nós" o entendemos como uma metáfora, no sentido mais desencantado do termo. No entanto, esta afirmação pertence ao seguinte contexto.

Pensemos na discussão (e eu vou formulá-la, propositalmente, do jeito mais simples possível): a realidade é uma só ou muitas? Pensemos agora num caleidoscópio. Ele é um ou muitos?

Historicamente, a Mística parece conceber, em conformidade com a Religião, a relação entre "o um" e o "múltiplo" como uma dualidade na qual, evidentemente, a unidade - ou o monoteísmo - seria superior. No entanto, o estudo aprofundado mostra que, trilhando fora da estrada da Religião, o olhar místico é uma combinação de ambas as "visões" no sentido de que a ênfase na unidade, muito longe de ser uma idealização, uma crença ou uma construção (no sentido técnico desses termos), possibilita um trânsito incessante entre as realidades. Dito de outro modo, ao nos perguntarmos se há uma ou muitas realidades, o que é crucial não é a questão quantitativa mas, sim, se essas muitas realidades se comunicam, se interpenetram ou se entrechocam, enfim, se há alguma possibilidade de deslocamento entre realidades - e não apenas intra - de modo que não haja nunca nenhum "fora", como poderia dizer Derrida.

Desse modo, pensar a multiplicidade dentro da unidade implica em unificá-la pela possibilidade de relação entre realidades, a unidade, sendo, a rigor, a relação: tudo se relaciona. Este modo de ver encontra, como veremos, incontáveis referências na obra de Ibn 'Arabî.

Ao mesmo tempo, se nos perguntarmos se, para este mestre andaluz, a única realidade, isto é, Deus, equivale à relação, seremos obrigados a constatar que a resposta será sempre uma espécie de "sim, mas não só". Visto nesta montagem, Deus é relação. Mas a 
imaginação mística é prodigiosa, e veremos ainda muitas outras montagens.

O encantamento quer dizer não que o homem seja capaz de conceber - como Derrida essa profusão de realidades e possíveis trânsitos entre elas mas, sim, que ele é capaz de realizar essa profusão e de transitar intencionalmente dentro dela ou, para usar de maior precisão, de sê-la intencionalmente. Coisa impensável para "nós, ocidentais contemporâneos". Dito de outro modo, o Encantamento seria uma espécie de ciência prática. Todo um portal de novas questões abre-se com esta distinção.

"O verdadeiro sábio é aquele que põe em prática o que sabe", disse Dul Nun Misri" ${ }^{19}$ e "Se você quer ver aquele a quem Deus destinou o inferno, olhe aquele que não pratica o que professa", assegura-nos Abu Yazid ${ }^{20}$. Um modelo mental como, por exemplo, o do pragmatismo neoliberal, dificulta a elucidação deste ponto. O praticar, isto é, colocar o conhecimento em ação, pode ser tomado em diversos níveis. Num nível, por assim dizer, macrocósmico, agir significa sintonizar-se e harmonizar-se com o fato de que tudo está em movimento, de que não há um saber fixo, genérico, ideal pois tudo é atual. Em níveis mais microcósmicos, os sufis afirmam que o trabalho espiritual consiste no desenvolvimento de órgãos sutis (lataif), por meio dos quais o conhecimento "adquire forma" no corpo e na vida. É nesse sentido que muitos textos falam em "virtudes técnicas" e não morais: a humildade, por exemplo, é uma posição técnica de "esvaziamento" interno que possibilita o aprendizado e só pode ser alcançada com a prática dos exercícios espirituais. Para efeito do presente trabalho, esta dimensão prática do Sufismo deve ser deixada de lado, posto que não se trata de propor um método espiritual mas, sim, um modelo pedagógico. Considero, no entanto, importante mencioná-la reiteradamente, como uma forma de evitar a violência - no sentido derridiano do termo - de supor que, mesmo sem ter desenvolvido estes misteriosos órgãos de percepção sutil, seríamos capazes de compreendê-la. Ao propor, portanto, um diálogo entre o Sufismo e o pensamento contemporâneo, sei, de antemão, dos limites deste em relação àquele, portanto, dos meus limites. Não obstante, há uma dimensão prática, isto é, de conhecimento não apenas mental, que se encontra na base do Encantamento e que, nesse sentido, não está restrita à elite espiritual ${ }^{21}$.

Se, como termo técnico, a ação, no Sufismo, refere-se ao fato de que tudo está em movimento, quer dizer que não é possível falar num saber que compreende formulações genéricas, abstratas e "fixas" que sejam independentes dos acontecimentos.

\footnotetext{
${ }^{19}$ Mestre sufi do séc. IX. Ver biografia.

${ }^{20}$ Outro mestre. Idem.

${ }^{21}$ A expressão "elite espiritual", utilizada por Ibn 'Arabî e presente no vocabulário técnico do Sufismo é possivelmente uma das principais razões do apreço dedicado a este ultimo pela Nouvelle Droite e outros partidos de direita na Europa. Evidentemente, a expressão designa aqueles que, por razões técnicas, se encontram preparados para realizar os sofisticados e exigentes trabalhos da Via e é inequivocamente difente da idéia de uma elite soi disant, autodestinada ao poder pela "superioridade de seu saber". Cf Stéphane François, Etudes et Analyses no. 21, Religioscope, 2009. A esse respeito, a obra de René Guénon foi utilizada ad nauseam por "guenonianos" que promoveram toda sorte de confusões entre a dimensão simbólica do poder numa sociedade tradicional (no sentido guenoniano do termo) e o poder moderno, tal como concebido pelas organizações de direita ao longo do séc. XX.
} 
Para um professor "moderno", é natural ensinar aos seus alunos que as leis pertencem ao domínio do que não varia e circunscrevem os dramas morais que se lhes apresentam nas mais variadas esferas da "globalização" dentro de uma casuística estritamente moral e esvaziada de qualquer conteúdo político.

Tanto para o pensamento contemporâneo quanto para o Encantamento, a idéia de um saber constituído e "pronto" ou, para lembrar a expressão de Merleau-Ponty, de um pensamento de sobrevôo é inaceitável. O saber é aquilo que se dá na ação porque ele é relação e relação sempre atual.

Retomo aqui a crítica feita por Merleau-Ponty às abstrações para distinguir a idéia de lei científica, jurídica, moral -, na Modernidade, da Lei simbólica no Mundo Encantado. Cito minha dissertação de mestrado ${ }^{22}$ :

A crítica de Merleau-Ponty ao "saber que sobrepaira" contém uma imagem de especial utilidade para nossa leitura. Trata-se de uma crítica à idéia de transcendência, vista como um saber genérico e autoritário pairando imutável sobre nossas cabeças (...) no caso do conhecimento místico, ainda que este, em algumas imagens, figure como sendo o conhecimento do que é "superior", não poderíamos traduzi-lo como o "saber que sobrepaira", pois, o que "sobrepaira" é crucialmente diferente do que é "celeste" - termo perfeitamente análogo a "superior". Em termos simbólicos, o que está no céu só pode ser visto por meio de medidas angulares enquanto o que é terrestre, "pairando" acima ou abaixo de nossas cabeças, nos aparece por medidas lineares.

O simbolismo geométrico da imagética celeste é uma demonstração de que a "superioridade" do que está acima não traduz uma hierarquia ideológica para justificar a cristalização de um saber ou de um poder mas, muito longe disso, descreve uma diferença de planos entre o simbólico (angular) e o imaginário (linear), diferença-chave em nossa perspectiva.

O "transcendente", o "celeste", jamais pode ser o que paira acima de todos, mas, conforme o simbolismo angular, é único para cada um, o que pode, facilmente, ser observado, por exemplo, num lugar qualquer a céu aberto: o zênite - ponto "mais alto" da cúpula celeste - é um ponto relativo que ocupa sempre o lugar exatamente acima da cabeça do sujeito que o observa. Para um suposto sujeito $A$, sua própria posição " $A$ " é central em relação à cúpula como um todo, já que o zênite é percebido como imediatamente acima. Para um sujeito $B$, no entanto, é sua posição "B" que constitui o lugar central, pelo mesmo motivo.

\footnotetext{
${ }^{22}$ Embora, seguindo o exemplo daqueles que admiro, eu considere que seja pouco elegante citar a si mesmo, passarei a me referir reiteradamente ao livro que resultou de minha tese de mestrado devido ao fato de que o presente trabalho consiste num desenvolvimento das idéias ali presentes. Cf. Sentidos do caleidoscópio, op. cit., p. 102-4.
} 
No livro "Clé spirituelle de l'Astrologie Musulmane d'après Muhyiddîn Ibn Arabî", Titus Burckhardt expõe a questão do seguinte modo:

"Esta coincidência das perspectivas não ocorre apenas quando focalizamos um ponto limite do céu, mas já quando olhamos um planeta. Ela se expressa na experiência corrente segundo a qual cada espectador que olha o sol nascer ou se pôr além de uma superfície de água vê a "via" dos raios refletidos na água virem diretamente em sua direção; quando o espectador se desloca, esta via luminosa o segue. Observemos, de passagem, que os índios da América do Norte consideram esse caminho luminoso projetado sobre a água pelo sol poente como o caminho das almas para o mundo dos ancestrais; de fato, pode-se ver nisso uma projeção "horizontal" do "raio solar" que, segundo o simbolismo hindu, representa o laço pelo qual cada ser particular liga-se diretamente a seu princípio. Sabe-se que os textos sagrados do Hinduismo descrevem este raio como o que vai da "coroa" da cabeça até o sol. O mesmo simbolismo - implicando simultaneamente as idéias de um laço direto e da "Via Divina" - encontra-se nesta passagem da Sura Hûd: Não há nenhum ser vivo que Ele não sustente por seu topete; em verdade meu Senhor está numa via reta (Cor, 11:56). Como a "Via Divina", a direção que vai de um ser terrestre qualquer a um ponto determinado da abóboda celeste é ao mesmo tempo única para cada um e uma para todos." ${ }^{23}$

Assim sendo, crer-se de posse de um saber adquirido, colocar a própria confiança no "saber" e não na Verdade (al- $\underline{H} a q q)$, gozar de tal estabilidade, é deixar-se enganar pelo "ardil divino" (makr). Mas encontrar na Lei, que é uma e uma para cada um, a Verdade que Ihe corresponde a cada momento, pois, "Aquele que conhece sua parte de Minha Lei, conhece a parte de Mim que lhe cabe"24 é, para o homem, a verdadeira submissão (al-Islam), na qual ele se torna o servidor (alabd) puro e, segundo uma fórmula de Ansâri ${ }^{25}$, frequentemente citada por Ibn 'Arabî, "então desaparece o que nunca foi e subsiste o que nunca deixou de $\operatorname{ser}^{1126}$.

O "homem perfeito" a que se refere Ibn 'Arabî é este homem "desperto", cujos lataif (órgãos de percepção sutil) encontram-se "acordados". Ele é irmão do universo e do Corão porque ele é capaz dessa relação que implica a unidade, ele a contém e entre eles não há "fora". E o Corão é irmão do universo porque ele é escrita, isto é, realidade enquanto multiplicidade e enquanto inscrição. E o universo é realidade enquanto perspectiva de unidade.

A existência é "uma escrita inscrita, testemunhada por aqueles que foram tornados próximos" (Corão, 83:20-1) mas ignorada por aqueles que não são próxi-

\footnotetext{
${ }^{23}$ Burckhardt, Clé Spirituelle de L'Astrologie Musulmane, d'après Mohyiddîn Ibn 'Arabî, op. cit., p. 20 , nota 2.

${ }^{24}$ Ibn 'Arabî, cit. e trad. por Chodkiewicz, in Océan, op. cit., p. 129.

${ }^{25}$ Al-Ansâri, sufi persa do séc. XI.

${ }^{26}$ Ansâri, cit. e trad. por Chodkiewicz, in Océan, op. cit., p. 158.
} 
mos. $^{27}$

Na Parte 2, veremos mais consequências da noção de Lei aqui esboçada.

A idéia de transcendência devendo passar pela mesma travessia: na tradição teológica, ela é o que está "fora"; no sufismo - para quem o teólogo pertence aos ulama al-zahir, os sábios do exterior - ela é salvaguarda contra um enclausuramento: é o que escapa, la chose même se dérobe toujours, disse Derrida. Em termos sufis, tudo o que é da ordem do divino ( $h a q q)$ é, por um lado, oposto, diferente ou superior a tudo o que é da ordem das coisas existentes (halq) e, por outro, é tudo o que é a própria ordem das coisas. Portanto, transcendência quer dizer aquilo que escapa da coisa mesma ${ }^{28}$.

Por essa via, a unidade, por dentro do encantamento, não é um conceito, nem uma positividade. Ela não "pertence" a um Deus transcendente e fixo em sua transcendência. Ela não constitui uma alteridade, tampouco uma identidade. Ela não se opõe à dualidade. Não é um elemento de lógica. Não é exclusivamente racional. E não é exclusivamente uma via negativa.

Ela pode ser contemplada como se fosse um conceito. De um lugar de transcendência ou de imanência, como alteridade ou como identidade, como oposta à dualidade ou não, como lógica ou supra-lógica ou ilógica. Como racional ou supra-racional ou irracional.

No Corão (versos 48, 115 da sura 4), o único pecado que Deus "proibiu-se de perdoar" é o politeísmo, isto é, numa tradução literal, o "associacionismo"29 (al-shirk), o fato de associar algo a Deus, pois la ilaha ila Allah (não há divindade senão Deus).

Para um sufi como Ibn 'Arabî, a unidade implica em que "o universo inteiro é uma teofania" e que aquele que não percebe isso é o pecador:

"A ascensão do walî (lit.: amigo, designa o sufi) é uma apoteose do olhar pela qual descobre-se a ele uma realidade que nunca deixou de estar presente a todos os seres mas que a maioria não verá neste mundo por falta de ter sabido "morrer antes de morrer" ${ }^{\prime \prime 3}$. O que é dito do Inferno numa outra passagem dos Futûhât confirma que a diferença entre o walî e o homem ordinário encontra-se inteiramente no olhar que põem nas coisas: a geena [inferno], para Ibn 'Arabî, foi criada

\footnotetext{
${ }^{27}$ Ibn 'Arabî, Meccan Revelations, op. cit., p. 43.

${ }^{28}$ Tratei da questão da transcendência de modo mais extenso em meu livro Sentidos do caleidoscópio.

${ }^{29}$ Esse termo quer dizer outra coisa em português, mas eu o utilizo aqui, por um lado, porque já propus anteriormente que ele tenha também esta nova acepção, e, por outro, para realizar a passagem da formulação corânica para o nosso entendimento atual.

${ }^{30}$ Alusão a uma fala do Profeta: "Morram antes de morrer e prestem a vocês mesmos contas antes que elas Ihes sejam pedidas".
} 
a partir da realidade essencial ( $\underline{h} a q i ̂ q a)$ que exprime o $\underline{\text { hadît }}$ qudsî $\hat{i}^{31}$ em que Deus, dirigindo-se ao pecador, declara: "Estive doente e não Me visitaste. Tive fome e não Me alimentaste... Tive sede e não Me saciaste..." Ao pecador que se espanta ("Como Te teria eu visitado, Tu que és o Senhor dos mundos?..."), Deus explica: "Meu servidor Tal esteve doente e se o tivesses visitado, ter-Me-ias encontrado junto a ele...": o Inferno não é, portanto, nada mais que a cegueira que impediu o homem de reconhecer Deus sob todas as Suas formas, de perceber Sua presença em cada coisa, em cada ser, em cada lugar, a cada momento. Esta cegueira daquele que olha as teofanias sem vê-las é a raiz do pecado e a substância mesma de seu castigo. Somente escapa aquele que conhece "sua própria realidade", (...) quer dizer, que se conhece a si mesmo como teofania de um Nome divino do qual ele é o lugar de manifestação (mažar). À sua transparência responde a transparência das coisas." 32

O pecado seria, então, tomar cada coisa como uma essência "por si", "independente de Deus" - o que equivale a lhe dar um estatuto que só Deus possui porque só Deus é - sem perceber que cada "coisa" é um "conjunto de relações" pois,

"... quando se fala das "essências das criaturas", é apenas uma maneira de exprimir a manifestação do Ser verdadeiro, quando este se reveste dos estatutos que implicam as predisposições das criaturas, isto é, seus protótipos imutáveis como o são na Ciência divina, não-existentes, desde sempre e eternamente: não sendo nada mais do que puros aspectos ou relações no seio da Realidade divina e não havendo aí nenhum ser próprio." ${ }^{33}$

Portanto, o pecado seria ver uma simples cadeira como cadeira, sem ver que ela é um Nome de Deus, isto é, um conjunto de relações possíveis ${ }^{34}$.

Assim, o único pecado que, dada a sua gravidade, é aquele que Deus proibiu-se de perdoar, é justamente aquele que nenhum ser humano é capaz de não cometer pois é perfeitamente evidente que ninguém - com a possível exceção de um místico - pode "ver" teofanias. Assim sendo, desde que o mundo é mundo, em todos os momentos e lugares, o homem pratica este que é o pior de todos os pecados e isso nunca poderá ser diferente.

Dito de outro modo, o pecado imperdoável é a idolatria. Na perspectiva mística, qualquer outro, se tomado à exclusão de Deus, isto é, como uma "identidade", como uma "essência", como um "ente", como "indivíduo", como uma "coisa", como uma "presença", enfim,

\footnotetext{
${ }^{31}$ Hadit (lit.) = novo, novidade, nova (profética). Este é o termo que designa as falas do Profeta Muhammad, compiladas em coletâneas. Qudsi = sagrado, a expressão Hadit Qudsi designa as falas transmitidas pelo Profeta em que Deus expressa-se na $1^{\text {a }}$. pessoa.

${ }^{32}$ Chodkiewicz, Le Sceau, p. 212-13.

${ }^{33}$ Abd el-Kader, Écrits, p. 89-90.

${ }^{34}$ A expressão "conjunto de relações" ainda é altamente insatisfatória para tudo o que está em jogo. Porém, ela serve a uma primeira aproximação.
} 
como qualquer coisa que possua uma definição ou uma fixidez de qualquer tipo, é um ídolo. Inversamente, qualquer outro que seja "sinal" (dalil) de Deus, portanto, sem identidade própria, é um outro possível, isto é, é uma teofania.

"Ele (Allâh) tem em cada coisa um Sinal, apontando para o fato de que Ele é Um Único Existente. ${ }^{135}$

A questão não está, portanto, no outro ou na identidade e sim no caráter plástico da realidade que está em constante movimento; e esta, como veremos, é a gênese do que chamarei adiante de simbólico.

Tradicionalmente, o que uma certa perspectiva teológica, por um lado, e certos formatos do pensamento moderno, por outro, asseguram, a partir do que foi dito acima, é que Deus, sendo a única realidade, é o que importa de fato, portanto, dar importância às coisas - aos prazeres, à política, ao estudo, por exemplo - é imiscuir-se ao mundano, ao menor. A mística, ao contrário, irá avançar neste caminho em todas as suas vertentes, entre elas, a que toma como evidente o fato de que Deus, sendo a única realidade, é a realidade de todas as coisas, portanto, tudo é importante: os prazeres, a política, o estudo. Evidentemente, não se trata dos prazeres circunscritos e codificados pela moral burguesa, não se trata da política entendida como pragmatismo neoliberal e nem do estudo genérico, racionalista e exclusivamente mental da Academia orientada para a ordem e o progresso.

Um exercício meditativo bastante recorrente na Mística consiste em fazer travessias da mutiplicidade, ou da dualidade - que é, habitualmente, uma síntese da multiplicidade até a unidade e vice-versa. Desse modo, a distinção (al-furqân), que é uma dualidade, não é vista como uma descrição da realidade, mas, sim, como uma manifestação de possibilidades, o que, a meu ver, pode ser igualmente ser chamado de "construção". Nos termos da Mística, a construção visa recortar um espaço e prepará-lo para ser habitado por algo. Podemos dizer que esse algo aceita ser chamado de "verdade", desde que se compreenda que quando, em ambiente místico, se fala em verdade no singular, nunca se está querendo dizer que a "verdade única" exclui "outras verdades". A unidade, tomada no sentido quantitativo, é comparável a quaisquer outras quantidades: há muitas verdades e escoIher uma delas significa excluir as outras. No entanto, no sentido qualitativo, a unidade é o que engloba e contém a multiplicidade. Assim, "a verdade" quer dizer "todas as verdades". Nesse contexto, o que os sufis dizem expressamente é que suas obras não falam a verdade, o que elas fazem é promover construções-distinções a fim de que a verdade "desça no coração" do leitor de suas obras. E dizem que fazem isso como uma imitação do Corão. Portanto, a respeito do Livro de Allâh:

"Incumbe-te distinguir entre compreender a Palavra e compreender Aquele que

\footnotetext{
${ }^{35}$ Ibn 'Arabî, "Sunday Morning Prayer", in The Seven Days of the Heart..., op. cit., p. 39.
} 
fala. É esta segunda forma de compreensão que deve ser buscada. Ora, esta só é obtida quando o Corão desce no coração, enquanto que a primeira pertence ao comum dos féis. Os gnósticos que recebem sua compreensão d'Aquele que fala compreendem a Palavra. Os que compreeendem somente a Palavra, não compreendem de maneira distinta, em totalidade ou em parte, o que quis dizer Aquele que fala." ${ }^{36}$

Aqui, a questão da ausência do falante - no texto escrito aquele que fala está ausente observada por Derrida, não se coloca. Allâh está sempre presente, e não se trata da presença da "coisa", ou da "identidade", ou da "essência", como vimos. Mais adiante, outras implicações desta questão deverão ser discutidas.

Assim, há, de diversos modos, uma distinção entre saber e verdade, ou entre construção e verdade: Aquele que fala é, na verdade, um Singular, pois dirige-se a um ouvinte singular.

"Entre as significações possíveis de uma palavra, de um verso, não há que escoIher por meio de um processo mental: o "verdadeiro" sentido - o que é verdade neste instante preciso, para este ser preciso - é o que surge, na nudeza do espírito, da letra mesma do discurso divino. É a esta letra, e a ela somente, que prestará atenção aquele cujo coração está pronto a acolher esta "chuva de estrelas" que cessará apenas no dia em que o Corão não for mais recitado "em voz alta ou em segredo"." 37

Desse modo, toda distinção é um trabalho de construção. Ao mesmo tempo, é também um trabalho de desmontagem ${ }^{38}$ pois, cada nova construção implica, sob certos aspectos, o abandono da anterior e os homens, como os tempos, variam. A referência corânica que abre o espaço simbólico e, portanto, a amplitude, dessa perspectiva é: "...a cada dia, Ele se ocupa de uma [nova] obra." (Cor, 55:29). Novamente, o abandono em questão não consiste sumariamente numa mudança de opinião, numa operação mental. Como veremos, há muito em jogo e cada abandono, numa certa perspectiva, consiste num sacrifí$\mathrm{cio}^{39}$.

As travessias que partem da multiplicidade em direção à unidade e vice-versa, são, então, as obras cuja intenção é, a cada momento, encontrar-se com o destino singular e atual de cada viajante, ou de cada grupo de viajantes, ou povo, ou época, etc.

\footnotetext{
${ }^{36}$ Ibn 'Arabî, cit. e trad. por Chodkiewicz, Océan, p. 47.

${ }^{37}$ Chodkiewicz, Océan, p. 54.

${ }^{38}$ Não uso, obviamente, o termo "descontrução" porque o sentido preciso que ele adquire a partir de Derrida não se aplica inteiramente ao contexto. Não obstante, a aproximação da desconstrução com diversos temas do Shayh (Ibn 'Arabî) pode ser proposta de vários modos. Cf. "Sufism and deconstruction", op. cit.

${ }^{39}$ Não é preciso dizer o quanto esta idéia, mal compreendida ou distorcida por má fé, foi utilizada para fins totalmente diversos dos que aqui se apresentam.
} 
Com essa colocação absolutamente sintética, estou começando a construir um recorte que vai necessariamente ter que nutrir-se em parte do pensamento de Derrida quanto ao descentramento da estrutura e o pensamento da diferença. No entanto, não me interessa, nesse momento, abordar a complexidade das discussões que "opuseram" este filósofo ao Estruturalismo, sobretudo à Lévi-Strauss na famosa conferência em $1966^{40}$. É como se eu partisse já do princípio de que a estrutura é descentrada, de que a desconstrução, como respiração da própria cultura, já está assumida no cenário que quero propor e, ao mesmo tempo, este cenário já está dialogando com o Sufismo atual e com os sufis dos séculos anteriores e sua própria maneira de tratar o descentramento.

It is here were parallels with deconstruction become most interesting; just as Derrida sees all metaphysical thinkers as basing their thought-systems upon illusory moments of "self-presence" - a "centre" which is never really the centre, a signifier which can only ever lead to other signifiers - Ibn 'Arabî sees all reflective thinkers as building their ideas about God on something which is not really God. In both cases, the philosopher falls victim to a certain illusion - the unquestioning conviction that the semantic foundation of the thinker's thought-system ('God', 'experience', 'reality', 'innocence') is somehow sufficient in itself, and requires no further justification. ${ }^{41}$

Com toda a evidência, no Encantamento, se o centro de qualquer estrutura é Deus e Deus é o que está em toda parte pois "para onde quer que vos volteis, lá estará a Face de Allâh" (Cor, 2:116), quer dizer que a estrutura é descentrada.

\footnotetext{
${ }^{40}$ Colóquio As Linguagens Críticas e as ciências do homem na Universidade de Johns Hopkins (Baltimore).
}

${ }^{41}$ Ian Almond, Sufism and Deconstruction - a comparative study of Derrida and Ibn 'Arabî, op. cit., p 15. 


\subsection{QUARTA APROXIMAÇÃO - O MUNDO DAS ANALOGIAS $\left(A L-A L \hat{A} M A L-M I T \hat{A} L^{42}\right)$}

O pensamento analógico cumpre papel fundamental na organização do presente trabalho.

Ibn 'Arabî utiliza a expressão alâm al-mițâl, mundo das analogias, para nos fazer ver a realidade - isto é, tudo o que pode ser conhecido - como sendo integralmente tecida de analogias. As implicações desta perspectiva são infindáveis e aqui pretendo trabalhar apenas com algumas delas.

Pelo pensamento analógico, qualquer relação pode traduzir-se em outra. Se dissermos que o sol é o centro do sistema solar, o coração é o centro do corpo humano, o rei é o centro do reino e o leão é o centro da floresta, temos que os termos "sol", "coração", "rei" e "leão" são intercambiáveis entre si.

$\begin{array}{ccccc}\text { sol } & \text { coração } & & \text { rei } & \text { leão } \\ \text { s solar } & = & \text {---------- } & = & \text {------------ }\end{array}$

Além disso, utilizando a mesma estrutura, podemos dizer que, considerando o par "unidade - multiplicidade", o centro é a unidade e a circunferência é a multiplicidade. Assim, se quisermos considerar o par "sol - lua", diremos que a lua é a multiplicidade, e do mesmo modo, o faremos para "reino", "corpo" e "floresta".

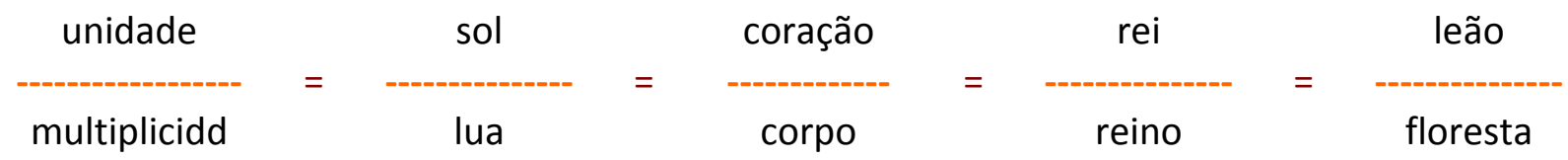

\footnotetext{
${ }^{42}$ A letra "t" deve ser lida como o "th" da palavra think em inglês.
} 
Assim, teremos idéias como: "a lua multiplica a luz do sol em 4 partes", "o rei é o sol do reino", "o reino é a manifestação (multiplicidade) do rei", "o leão é o rei da floresta", "o coração reina sobre o corpo", "o corpo é a forma (manifesta) do coração", etc.

Pela mesma via, se, em vez de considerar o par "coração - corpo", considerarmos o par "coração - cérebro", teremos uma analogia com o par "sol - lua" na qual o coração será o sol e o cérebro a lua.

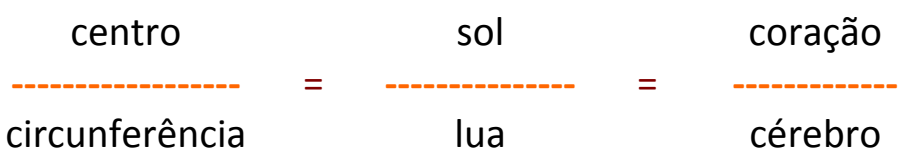

Diremos, nesse caso, que o cérebro desdobra (multiplica) a "energia" do coração e a transforma em atividade mental reflexa, assim como a luz da lua é o reflexo desdobrado da luz do sol. Por outro lado, se o nosso primeiro par for, agora, "cérebro - mão", o cérebro será o sol e a mão, a lua. Diremos, então, que o movimento nasce no cérebro, que dele é portanto o centro, e vai manifestar-se na mão, que é a sua expressão última, assim como a circunferência é a expressão do centro.

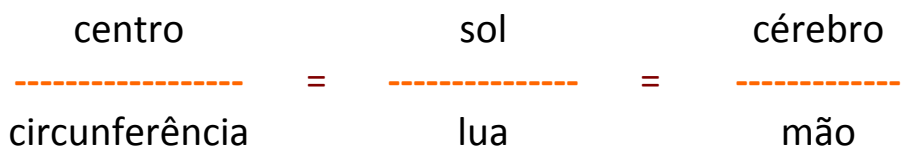

Num momento, o cérebro é a lua, noutro, o sol.

Todas essas combinações são montagens possíveis, porém, obedecem a regras, são arranjos combinatórios segundo leis da analogia. Geometricamente falando, são como um caleidoscópio, no qual as formas podem mudar indefinidamente, porém, sempre mantendo uma organização "de fundo".

Desse modo, tudo está em relação: "o que está em cima é igual ao que está embaixo", "o que está dentro é igual ao que está fora", "o um é igual ao outro". Sendo que a igualdade aqui não é lógica, é analógica.

A idéia de que tudo se relaciona, sem o dado fundamental da relação analógica, tem produzido uma série considerável de distorções, vulgarizações, contrafações e perversões ao longo do Desencantamento, sobretudo nas chamadas "Ciências Esotéricas". Como o estudo e a crítica do "esoterismo desencantado" não faz parte do escopo do presente trabalho, contento-me em registrar aqui um texto de raro poder de síntese, com o objetivo de, pelo brilhantismo e pela irreverência de seu autor, livrar-me, de um só golpe, de um 
universo de besteiras que, todas as noites, rondam invejosamente as alegres danças e as meditações rituais dos disciplinados moradores do mundo analógico encantado.

"Tudo se relaciona. É só descobrir as conexões certas que você decifra o mundo. Mas atenção: as conexões certas. O "blue denim", tecido com o qual são feitos os "jeans", sem os quais você não compreende o tempo em que vive, tem esse nome porque era produzido originalmente em Nimes, na França. Era o tecido "de Nimes". "Jeans" também vem da França. Tem alguma coisa a ver com o nome francês para Gênova, Itália, de onde saiu Cristovão Colombo para descobrir a América.

No relato bíblico do Dilúvio, Noé solta uma pomba para descobrir terra seca. A pomba voa para o Oeste, descobre o novo mundo, onde Noé e seus bichos recomeçarão a vida, e volta com um ramo no bico. Ramo tome nota. Pomba, em latim, ou coisa parecida, é "colomba". Colomba - Colombo. Hein? Hein?

O inventor do "jean" foi o famoso antropólogo Lévi-Strauss, francês, possivelmente de Nimes. Foi quando esteve no Brasil pesquisando o seu livro Tristes Trópicos - obviamente, não veio na época do carnaval - que Lévi Strauss se convenceu da necessidade de calças fortes para andar na floresta, resistir aos ramos (!) e espinhos e às mordidas de índio. Lévi Strauss, junto com o "jean", desenvolveu uma teoria sobre carne crua e cozida e sobre o que isso significa na cultura dos povos. Segundo Lévi Strauss, havia um ponto exato entre o mal e o bem passado que determinava quando uma civilização, já livre do primitivismo, ainda não começara a decadência. Hoje, quando pedimos uma carne "au point", é ao ponto de Lévi Strauss. Que é do ramo francês da família que, na Áustria, inventou a valsa e nos deu o compositor de, entre outras, o Danúbio Azul. Azul em inglês é "blue", como o denin. "Blues", ou azuis, é o nome da canção dos negros escravos do Sul dos Estados Unidos. Foi no Sul dos Estados Unidos que nasceu o maior concorrente de Lévi-Strauss no ramo - de novo a palavra ramo - dos "jeans". 0 general Robert $\mathrm{E}$. Lee, que patenteou as calças Lee. $\mathrm{E}$ tudo isso aconteceu onde? Na América descoberta por Colombo, o pombo genovês, e onde anos depois nasceria Calvin Klein, que não tem nada a ver com a história. Azul também é a cor da camiseta a seleção da Itália, país onde este ano se realizará o campeonato do quê? Do mundo! Tudo se relaciona. A última cultura indígena organizada no Brasil é a da tribo carnavalesca Cacique de Ramos (Ramos!). "Indigo", outro nome para o azul dos "jeans", vem da Índia. E onde é que Colombo, a rola "azzurra", pensava que estava quando chegou à América? Onde? Tudo se esclarece, como se vê." (Luis Fernando Veríssimo)

Assim como, num dado momento, a partir do par "unidade e multiplicidade", o cérebro é a lua e, noutro, o sol, a partir, por exemplo, da "unidade - multiplicidade", ou da "imanência - transcendência", Deus, num dado momento, pode ser visto como homem, noutro, 
como mundo. E vice-versa para cada termo.

Simplificadamente, Deus pode ser o mundo, o homem pode ser Deus, e o homem pode ser o mundo. Assim como uma borboleta pode ser Deus, ou o homem ou o mundo. Ou um clips, ou uma coca-cola. Não é difícil ver porque idéias deste tipo suscitaram tantas reações violentas por parte dos juristas islâmicos (fuqahâ) contra os sufis.

Tecnicamente falando, esta é uma propriedade do pensamento analógico que, por sua vez, é um dos modos da razão. Como estamos no Mundo Encantado, não se trata de crer que a realidade seja analógica, trata-se de trabalhar com ela por meio da analogia.

Daí a construção de Ibn 'Arabî, lendo um verso do Corão, em que ele integra duas perspectivas tradicionalmente antagônicas: a imanência e a transcendência.

A transcendência divina expressa-se na impossibilidade de que Deus encontre qualquer semelhança com o mundo. A imanência, ao contrário, traduz-se pela similitude, isto é, pela possibilidade de analogia entre Deus e a Criação.

"... a leitura que faz Ibn 'Arabî do célebre versículo (Cor. 42:11), Laysa ka-mitlihi shay'un, que pode ser compreendido como significando: "Não há nada que Lhe seja semelhante" ${ }^{43}$. Muitas páginas seriam necessárias para analisar em detalhe os numerosos textos em que Ibn 'Arabî evoca este verso. Resumindo, o problema colocado por este versículo gira em torno da partícula $k a$, "como". Seria ela supérflua, destinada simplesmente a reforçar a palavra mitll, "semelhante"? Esta é, entre muitas outras, a opinião de Qushayri (ob. 1072), a quem se deve o primeiro tafsîr [comentário] sufi completo que chegou até nós, e para quem esse $k a$ é apenas uma partícula desprovida de sentido próprio (...). Sem recusar esta maneira de compreender o versículo, que ele mesmo adota várias vezes em sua obra, já que ela é linguisticamente admissível, Ibn 'Arabî a complementa por uma outra que é exatamente seu oposto. Deus não fala para nada dizer: a partícula $k a$ pode portanto conservar toda a força de seu sentido normal. E o versículo significa então: "Não há nada como Seu semelhante" - interpretação que, para os fuqahâ (juristas), é supremamente blasfematória.

Quem é este mitll, este "semelhante" de Deus? É o homem - mas, bem entendido, o "homem perfeito", al insân al-kâmil, enquanto Halîfat Allâh, "lugartenente" de Deus sobre a terra (Cor 2:30; 7:79; 35:39)." ${ }^{44}$

Assim, na perspectiva do mundo das analogias, um mesmo verso do Corão pode ser lido em dois sentidos opostos, de modo que a oposição, por esta via, torna-se uma aparência.

Uma questão importante surge aqui: se tudo pode "ser qualquer coisa", se a realidade é inteiramente plástica e mutável, como distinguir entre o falso e o verdadeiro?

\footnotetext{
${ }^{43}$ Literalmente: não há coisa semelhante a Ele. (N.T.)

${ }^{44}$ Chodkiewicz, Océan, p. 57.
} 
De fato, quando vemos a facilidade com que campanhas políticas fazem uso de analogias para "defender" uma idéia, como, por exemplo, a analogia entre Hitler e Sadam Hussein feita pelos Estados Unidos a fim de "justificar" a guerra, ou a utilização de versos do Corão por parte do Taleban para dinamitar estátuas budistas no Afganistão, fica evidente que o procedimento analógico não pode ser usado argumentativamente.

Como uma aproximação inicial, podemos dizer que, na perspectiva encantada, o pensamento analógico não objetiva uma distinção de ordem ética ou filosófica. Ele se presta a estabelecer condições de aprendizado, a desenvolver faculdades cognitivas, a "preparar" a intuição. Sua função, nesse caso, é pedagógica.

Assim, um primeiro "critério de verdade" para uma relação analógica é se ela é realmente experimentada internamente.

A expressão acima também pode ser problemática para nós. A idéia de uma experiência interior não deve ser confundida com uma experiência subjetiva, tal como a definiríamos na Modernidade.

Ibn 'Arabî utiliza o termo dawq (gosto, experiência gustativa) para designar o conhecimento obtido por experiência. As traduções comuns ao termo são: "experiência pessoal direta", "experiência espiritual", "conhecimento gustativo"45.

Quando, despertada no meio da noite, uma criança está com medo de ser atacada por vampiros, esta é uma experiência subjetiva ou um sintoma. Se a criança, porém, "entra em contato" com os vampiros e distingue neles alguma singularidade, para efeito do presente trabalho, podemos dizer que este é o início de uma experiência interior.

Na obra de Ibn 'Arabî, o alâm al-mitâal possui graus de analogia com o alâm al-hayâl, o mundo da imaginação. Ao longo do presente trabalho, voltaremos inúmeras vezes a estas questões. Numa primeira aproximação, podemos dizer que a imaginação é o aspecto "denso" do alâm al-mitâl. Por meio dela, desfaz-se o aparente antinomismo dessa profusão de possibilidades em que tudo parece poder ser qualquer coisa, como numa sucessão "pós-moderna" de narrativas, sem expiração nem inspiração. No alâm al-hayâal, o entendimento ganha forma, peso, consistência e, sobretudo, gosto ( $\underline{d} a w q)$.

Uma idéia presente em boa parte das reflexões sobre Educação é que os ensinamentos devem buscar uma conexão concreta com "a realidade dos alunos". A partir de Paulo Freire, essa idéia ganhou matizes variados. Aqui, espero contribuir para esta discussão com uma distinção. A "realidade" de boa parte dos alunos globalizados inclui, de modo assustadoramente amplo, a presença perene em suas vidas do mercado de consumo e da "ética" mercadológica. Paradoxalmente, seria agora desejável que a Educação fosse, antes de tudo, contraditória com esta "realidade". A distinção com a qual passarei a trabalhar é

\footnotetext{
${ }^{45}$ Cf. Meccan Revelations, op. cit.
} 
então a seguinte: na perspectiva encantada, a realidade é ilusória, mas a realidade atual, não. Nesta, há "prova", travessia singular, dawq.

Uma criança chora. O que fazemos normalmente é pedir-lhe que pare de chorar e nos explique o que está acontecendo. Para corresponder ao nosso pedido, ela pode buscar alguma palavra de seu pequeno repertório e nos dizer, talvez, que está triste. No entanto, esta palavra torna presente muito pouco ou quase nada da experiência em si. Como resultado, perguntamos - como se isso pudesse trazer algum conhecimento - por que ela está triste, inserindo-a, assim, na cadeia causal da qual ela provavelmente jamais sairá. Ela nos dará alguma resposta que lhe pareça satisfatória. E nós tentaremos convencê-la a alegrarse, dizendo outras palavras do nosso repertório que lhe indiquem, talvez, que não há motivo real para tristeza, que faremos algo para eliminar a causa da tristeza ou que lhe daremos algo em compensação. Em todos os casos, estaremos implicitamente dizendo-lhe que não é bom que ela fique triste, que é bom fazer o possível para eliminar a tristeza.

Na semana seguinte, se ela chorar novamente, o processo se repetirá e todos acreditarão que há uma tristeza recorrente. Porque o nome é o mesmo, diremos que a experiência é a mesma.

Por outro lado, se lhe pedirmos que, em vez de dar um nome genérico para o seu sentimento, nos dê uma analogia dele, como por exemplo, "que bicho seria isso que está acontecendo aí dentro de você?" Ela diria, é uma minhoca de gravata que está muito brava e fala alemão enquanto come um bolo quentinho. E nós deixaremos que ela siga contando uma história do que está sentindo e pensando e a incentivaremos com perguntas. $\mathrm{O}$ que ela sente não ganha um nome, um rótulo vazio. Ganha uma história, uma travessia, uma situação analogicamente transmissível na linguagem verbal. Ganha, portanto, forma, realidade para o outro. Aquele sentimento que, muito provavelmente, pertencia à ordem da angústia, do indizível, do Mistério - e, por isso, não encontrava pouso na pobre, indigente realidade egóica - disfarça-se de fábula e penetra, com o seu manto de amplitudes, no ainda insípido mundo do imaginário infantil. O que, implicitamente, estamos lhe dizendo é que a angústia tem pouso, não precisa ser afastada, anestesiada, alijada.

E o que tecnicamente estamos lhe dizendo é que ela pode, pouco a pouco, com a utilização de um método analógico, ir construindo dentro de si os meios de escuta disso que está querendo ser dito e que se origina do seu lugar de ser singular.

Na semana seguinte, a criança chora. Mas, dessa vez, o sentimento que está acontecendo ali é a asinha de um pássaro que voou, voou prá muita lonjura e ficou cansada de tanto bater e falou pro pássaro que ele precisava fazer umas férias imediatas. A experiência é totalmente outra. Tudo variou, o momento é outro. E a criança não será obrigada a pensar: "estou sempre triste, há algo de errado comigo". Porque esta é uma construção imaginária que o modo habitual de tratarmos o ego lhe impõe: o modo no qual as palavras e as coisas, a despeito de Foucault e de toda a filosofia do séc. XX, ainda são tratadas como ligadas por uma relação de representação. 
A diferença entre o choro minhoca e o choro asinha de pássaro não pode ser explicitada racionalmente, não pode ser cristalizada nem esgotada. Ela exige um trânsito, um passeio pelo conjunto de possibilidades que ela estabelece. Nesse passeio, é possível encontrar lugares, coisas não sabidas porque as relações não foram estancadas pela palavra/rótuloimaginário "triste".

Assim, no que se passa entre a minhoca e a asinha de pássaro, a criança pode surpreender-se com possibilidades suas que ela desconhecia, com lugares novos - portanto, capacidades, sentimentos, idéias, etc. de outra qualidade. Nesse passeio, as palavras são o que nasceram para ser: asas, canoa, caminho, passagem. Isto é, são sempre mais do que são, seu destino sendo o de transcender-se:

"Na estrada das Tabocas, uma vaca viajava. Vinha pelo meio do caminho como uma criatura cristã..." (J. Guimarães Rosa, Sequência, in Primeiras Estórias) ${ }^{46}$

A vaca que, como todo símbolo, leva o homem na direção do Misterioso, do milmaravilhoso, "transcendia ao que se destinava" (pg. 434).

Qualquer coisa pode ser qualquer coisa, no entanto, nem todo mundo pode realizar de fato esse ser qualquer coisa. Fazer uma relação analógica consiste numa simples operação mental, mas, tornar-se efetivamente essa relação resulta de uma experiência concreta, atual.

Desse modo, o alâm al-mițâl não é nem positivo nem negativo, ele é um mapa de navegação.

Se podemos traduzir a palavra sol, no português, para soleil, no francês, também podemos traduzir a palavra sol, no sistema solar, por leão, na floresta, havendo, nesse caso, analogia entre estes dois tipos de tradução.

De certo modo, o alâm al-mitâl pode ser visto como um estruturalismo avant la lettre no sentido com que Descombes define uma de suas propriedades:

"A definição de um código é de ser traduzível num outro código: esta propriedade que o define chama-se: estrutura."

No caso, porém, da perspectiva em questão, há implicações de outra ordem. Se o sol do sistema solar é o leão da floresta, quer dizer que há também um sol ou leão em qualquer outra realidade além da floresta ou do sistema solar. E, além do sol, haverá também uma

\footnotetext{
${ }^{46}$ Obras Completas, Vol. II, Ed. Nova Aguilar, Rio de Janeiro, 1995.

${ }^{47}$ V. Descombes, "Le même et l'autre", in Minuit, 1979, p.121.
} 
lua, uma terra, uma vênus, etc. Ou, melhor dizendo, se podemos traduzir qualquer coisa do português para o francês, também podemos traduzir qualquer realidade para qualquer realidade, desde, é claro, que possamos transformar essas realidades em linguagem. Não vou definir agora o termo linguagem.

Um decorador olha uma sala de visitas com um olhar diferente do de alguém que simplesmente a visita. A combinação dos elementos ali dispostos parece-lhe mais ou menos harmônica, ele pode descrever o ambiente fazendo-nos constatar uma realidade antes apenas tácita para nós. Por meio de sua descrição, a sala fala. E nós, se colocamos nossa sensibilidade para ajustar-se a esta tradução, ouvimos. Caso contrário, podemos, talvez, dizer que o decorador "viajou na maionese" ou "pirou na batatinha" ou "bebeu", etc. ${ }^{48}$. Mais radicalmente, um músico presente na conversa pode decidir compor uma obra que traduza a eloquência da sala falante. E depois um bailarino pode fazer disso uma coreografia.

Um ponto importante a apresentar-se no contexto é: que relação interessante é esta que faz com que algo, como uma sala, fale. Dito de outro modo, se alguém se relaciona com uma coisa como se ela fosse uma linguagem, a coisa responde, torna-se fala atual e também pode ser traduzida em qualquer outra linguagem. Agora, o interessante é o lugar onde se põe esse alguém: quando, por exemplo, um leitor francófono depara com uma palavra em francês que ele desconhece, em muitos casos, ele pode deduzir o seu sentido em função do contexto, ou buscar o dicionário, ou pular a frase, etc. Para um leitor não francófono, a relação com a mesma palavra é de uma quase impossibilidade. O mesmo se pode dizer de alguém que, não tendo nenhuma familiaridade com o futebol, e, encontrando-se eventualmente numa pelada entre amigos, sinta que o campo é grande demais, que a bola não fica parada convenientemente para que se possa chutá-la, ou que os adversários são excessivamente rápidos, de tal modo que a experiência termina por parecerIhe totalmente sem sentido. Já a malícia de um moleque que joga a bola para a direita e seu corpo para a esquerda a fim de desnortear o adversário e ultrapassá-lo para recuperar a bola mais adiante exige que ele esteja à vontade com o tamanho do campo, com o seu próprio fôlego, com os companheiros que velozmente se deslocam atrás dele e com o fato de que a bola quer-se do outro lado do goleiro, estufando a rede. Do mesmo modo, uma pessoa que experimenta uma dor dentro de um conjunto de sensações, percebendo, sem ver, velozes mudanças em distintos pontos de seu corpo, utilizando sua respiração, seu relaxamento para driblar a força do desconforto e estando em contato com o fato de que algo ali deseja, é diferente de alguém que experimenta uma dor como um acontecimento estranho e isolado ou "fora".

Em outras palavras, a produção de sentido não é uma produção de "sentido mental", não é uma explicação, nem uma verbalização, nem uma abstração. É uma experiência atual dentro de um campo total, pois toda linguagem é uma totalidade no sentido de que basta a si mesma para dizer-se, no sentido de que o português não precisa do francês para ser

\footnotetext{
${ }^{48} \mathrm{O}$ que, evidentemente, não exclui o fato de que alguns decoradores "viajam" mesmo.
} 
claro.

A relação com uma linguagem é uma relação de intimidade: há um saber e um permanente não-saber, um encontro - que pode ser angustiado ou alegre - da ordem misteriosa da totalidade da linguagem com o momento atual, sempre imprevisto e cujo sentido está sempre por fazer-se, como a palavra que escrevo agora e o drible que o jogador inventa daquele modo, precisamente naquela hora, mesmo depois de tê-lo ensaiado centenas de vezes.

Nesta perspectiva, a relação com o imprevisto é uma relação de improviso, portanto, ao mesmo tempo de lembrança, de aprendizagem e de invenção.

A idéia de intimidade é importante no contexto. Uma apaixonada discussão entre Educadores ao longo do séc. XX é a que antagonizou "resultado" e "processo". Uma criança que tivesse intimidade com alguma matéria em particular, a rigor, não poderia ser inserida nem na perspectiva de um nem na de outro ${ }^{49}$. O moleque que apenas quer fazer gols ou somente aprender mais sobre futebol não é esse menino malicioso que joga em harmonia com as possibilidades do jogo.

O que, encantadamente, pretendo considerar é que a intimidade é o que resulta de uma relação com uma coisa tornada linguagem.

Ver numa coisa uma linguagem é um dos eixos da urdidura pedagógica que aqui se esboça. Em síntese, o pensamento analógico é um exercício, um treinamento preparador da posição que permite olhar a realidade como linguagem.

\footnotetext{
${ }^{49}$ Claro está que muitos educadores nunca viram tais questões como um antagonismo e que muitos defensores do "processo", embora não utilizassem essa terminologia do modo como a utilizo aqui, referiam-se a uma perspectiva muito semelhante.
} 


\subsection{QUINTA APROXIMAÇÃO - UMA NOÇÃO DE SUJEITO}

Passo, agora, a focalizar uma distinção que será muito importante ao longo deste trabaIho. O "treinamento preparador", possibilitado pelo pensamento analógico, é um trabalho sobre o ego.

Num primeiro movimento de distinção, o ego é crença de identidade e movimento de identificação. É ver uma cadeira como cadeira e não como "conjunto de relações".

Retomando, então, a discussão sobre o "pecado que Deus proibiu-se de perdoar" (cap. 1.3), - que é o pecado de ver as coisas como identidades, como fixidez ou definição - a fixidez das coisas é fruto da percepção egóica. Ego quer dizer recorte, fixação, manutenção, definição, limite.

Este modo de ver o ego, cujo termo correlato em árabe é nafs, é uma construção a partir de Ibn 'Arabî e do Sufismo. Nafs, que também é comumente traduzido por "alma" e pode, sob certos aspectos, ser assimilado à consciência, designa, entre muitas "definições", o lugar intermediário entre o corpo e o espírito de tal modo que o corpo pode ser visto como uma "nafs densa" e o espírito como a forma mais sutil da nafs. É habitualmente o lugar da luta espiritual, o campo das ilusões que se desfazem quando recebem a luz espiritual do Conhecimento, sendo um dos aspectos mais característicos da ilusão justamente a idolatria, ou, apropriando-me de uma expressão da Escola de Frankfurt e utilizando-a nos meus próprios termos, a reificação da realidade, a idéia de que as coisas existem como coisas em si, independemente das relações que as constituem. No dizer de Qushayrî, um importante sufi do séc. XI, falando sobre Abrahão: "O fatâ (jovem herói) é aquele que quebra o ídolo. E o ídolo de todo homem é seu ego (nafs)".

Portanto, o "pecado imperdoável" - a idolatria, isto é, a incapacidade de ver Deus em todas as coisas - é inerente ao ego, isto é, é parte constitutiva do sujeito nesta vida. 
Ou seja, nesta perspectiva, de duas uma: ou a Revelação está destinada exclusivamente àqueles que, segundo a terminologia por eles utilizada, extinguiram o próprio ego, os chamados eleitos, e todos os restantes nem deveriam dar-se ao trabalho de ler o Corão, pois não podem deixar de pecar, ou a Revelação dirige-se igualmente a várias "dimensões" humanas - várias escritas - inclusive, novamente, a "algo" no homem, em qualquer homem, que é capaz de ver teofanias.

Chamado acima de "verdade" e visto, agora, sob outro aspecto, este "algo" - que não é somente um lugar, nem apenas um órgão cognitivo, ou uma essência - aparece em Ibn 'Arabî e no Sufismo com inúmeros nomes, sendo um dos principais o termo "coração"50.

Novamente, a distância entre o desencantamento e o Mundo Encantado se faz ver: nosso hábito mental nos faz pensar o coração como o lugar das emoções, do amor brega, da generosidade ingênua, numa palavra, do ego mais vulgar. No Encantamento, o coração é o lugar do segredo (sirr), do singular, daquilo que, em cada homem, é capaz de ver teofanias, mesmo que o ego não possa dar-se conta disso.

Vale insistir: este é um modo encantado de falar do "sujeito", no caso, um modo dual. Não quer dizer que os sufis "vêem" o homem como dotado de coração e alma (ou ego), mas, sim, que esta é uma das muitas montagens que os sufis fazem a fim de fazer notar certas dimensões deste ser "não terminado" ${ }^{51}$ que é o $\underline{\underline{H}}$ alifat Allâh (Califa de Deus) na terra (Corão, 2:30; 7:79; 35:39).

Nesta montagem extremamente sintética, começarei estabelecendo um antagonismo conceitual entre o ego e o coração. Aos poucos, esse antagonismo dará lugar a outras formas, mais sofisticadas, de relação entre ambos, até que possamos passar dessa dualidade a uma multiplicidade, na qual o homem se apresente com diversos níveis de "coração" e de "ego" bem como com níveis de "coração-ego" e "ego-coração".

A diferença entre coração e ego manterá uma analogia com a diferença entre mundo encantado e mundo desencantado. O objetivo desta analogia não é estabelecer o que Derrida chamaria de dualidade hierarquizante, isto é, de fazer o elogio idealizador do encantamento e a "satanização" do que apareceria como "seu oposto", já que, como vimos, tanto o mundo encantado quanto o desencantado não existem em si, do mesmo modo como, no caso, o coração e o ego. O que a analogia visa aqui é começar a longa construção de um alâm al-mitấl $\left.\right|^{52}$ que sirva aos nossos propósitos pedagógicos.

A distinção entre coração e ego é um divisor de águas entre o sufismo e o pensamento

\footnotetext{
${ }^{50}$ Que, por sua vez, possui às vezes 2 faces, às vezes 5 , às vezes inúmeras.

51 "O senhor... Mire veja: o mais importante e bonito, do mundo, é isto: que as pessoas não estão sempre iguais, ainda não foram terminadas - mas que elas vão sempre mudando. Afinam ou desafinam. Verdade maior. É o que a vida me ensinou. Isso que me alegra, montão." Guimarães Rosa, Grande Sertão Veredas, op. cit., p. 20-1.

${ }^{52}$ Ver capítulo 1.4 .
} 
moderno. Sinteticamente, a alma engloba tudo o que chamamos de consciência e, atualmente, Inconsciente. A história individual, o tempo decorrido entre o nascimento e a morte, os trilhamentos, a memória, o corpo, os estilos, o sujeito e o sujeito do Inconsciente. O coração corresponde a uma realidade de certo modo desconhecida para "nós", gente do mundo desencantado. Digo de certo modo desconhecida porque ela não é totalmente desconhecida, embora a formulação que se segue pareça impensável para os tempos de hoje.

Cito o hadit qudsi $i^{53}$ incansavelmente meditado por Ibn 'Arabî: "Nem o céu nem a terra Me contêm, mas o coração do meu servidor fiel Me contém". O céu e a terra contêm tudo o que possui forma e, em princípio, poderia receber um nome particular ou, o que já foi chamado de mundo sensível, no qual inclui-se o sujeito e sua história. Deus não cabe nesse lugar mas cabe no coração do homem.

"O Corão é perpetuamente novo para cada um daqueles que o recitam (...). Mas nem todo recitador está consciente de sua descida (nuzûl) porque seu espírito está ocupado por sua condição natural. O Corão desce então sobre ele oculto atrás do véu da natureza e não resulta em gozo. É a este caso que alude o Profeta quando fala de recitadores que lêem o Corão sem que este vá além de suas gargantas. Este é o Corão que desce sobre as línguas e não sobre os corações. Deus disse, ao contrário, a respeito daquele que saboreia [esta descida]: "O Espirito fiel desceu com ele [= o Corão] em teu coração (Corão 26:193). Este é aquele a quem esta descida faz provar uma doçura incomensurável que excede qualquer gozo. Quando ele a experimenta, ele é [verdadeiramente] aquele sobre quem desceu o Corão sempre novo. A diferença entre esses dois tipos de descida é que, se o Corão desce ao coração, traz com ele a compreensão: o ser em questão tem o conhecimento daquilo que recita ainda que ele ignore a lingua da Revelação, ele conhece o significado daquilo que recita ainda que o sentido que têm essas palavras fora do Corão Ihe seja desconhecido porque elas não existem em sua própria linguagem: ele sabe o que essas palavras significam em sua recitação e no momento mesmo em que as recita. A estação do Corão e sua morada, sendo aquilo que dizemos, resulta em que cada um encontra nele aquilo a que aspira. É por esta razão que o Sayh $\underline{\underline{h}}$ Abû Madyan dizia: o aspirante (al-murîd) só o é verdadeiramente quando encontra no Corão tudo aquilo a que aspira. Qualquer palavra que não possua esta plenitude não é realmente Corão ${ }^{54}$. Quando o Corão, que é um atributo divino - e o atributo é inseparável daquilo que ele qualifica - desce ao coração, é portanto Aquele mesmo de quem o Corão é a Palavra que desce com ele. Deus disse que o coração de seu servidor fiel 0 contém ${ }^{55}$ : é nessa descida do

\footnotetext{
${ }^{53}$ Hadit (lit.) = novo, novidade, nova (profética). Este é o termo que designa as falas do Profeta Muhammad, compiladas em coletâneas. Qudsi = sagrado, a expressão Hadit Qudsi designa as falas transmitidas pelo Profeta em que Deus expressa-se na $1^{\text {a }}$. pessoa.

${ }^{54}$ Lembremos que a raiz da palavra Corão (qur'ân) exprime a idéia de "reunião" e de "totalização" (n. do trad.).

${ }^{55}$ Este hadit qudsî célebre é frequentemente citado pelos autores sufis com uma cadeia de transmissão re-
} 
Corão no coração do crente que consiste a descida divina ao coração." 56

Façamos uma "tradução" possível desse texto. Ibn 'Arabî afirma expressamente que "o universo é irmão do Corão". Isto é, o discurso divino não é sobre a realidade, ele é a realidade $^{57}$. A frase inicial do texto pode, então, ser lida como: "A realidade é perpetuamente nova para cada um daqueles que a recitam/ experimentam/ conhecem / com ela entram em contato (...)."

A realidade está sempre mudando porque os tempos, os lugares e as pessoas mudam, porque, nesse sentido, há algo de único, concreto e atual a cada momento. Mas, o ego não é capaz de perceber essa atualidade porque "seu espírito está ocupado por sua condição natural", isto é, o ego tende à fixidez, à repetição, aos processos identificatórios: "isso é uma mesa", "eu sou assim", "a negritude é isso", "são paulo é melhor que o rio", "Derrida é filósofo", "Lacan é psicanalista".

"A Guia (Guidance) é que o homem seja conduzido à perplexidade; que ele saiba que a Ordem [divina] é perplexidade, que a perplexidade é distúrbio e movimento, que o movimento é vida, de modo que não há nem repouso nem morte, que [o movimento] é "realidade atual", de modo que não há nada de irreal." ${ }^{58}$

O ego não é capaz de perplexidade, mas o coração é. O coração é o órgão da percepção sutil $^{59}$. o "sutil" é, sinteticamente falando, o aspecto "não denso", "não cristalizado" da percepção e que possui "plasticidade" e "capacidade" para assumir "todas" as formas.

"(...) Sir Lawrence Olivier conhece o começo e o fim da peça Hamlet, isto é, conhece a estrutura simbólica inteira que rege o drama. Mas Hamlet, que é a sua personagem, isto é, sua forma imaginária, nada pode supor sobre o desfecho de seu destino, menos ainda, pode suspeitar que aquilo que o anima - Lawrence Olivier - é que é real, seu Senhor - enquanto ele, Hamlet, não passa de ficção, assim como o drama que experiencia. Mas, no teatro, Olivier não pode aparecer como tal, ele depende de Hamlet para estar ali. Como pode Hamlet conhecer Lawrence Olivier? Somente se deixar de ser Hamlet para tornar-se Olivier. O espectador que vê Hamlet, poderia assistir Lawrence Olivier dependendo de onde se colocasse. "Dentro" do teatro, "envolvido" com a peça, ele vê Hamlet, "desenvolvido", tendo aberto a "visão interior", vê Olivier. Para tanto, tem que "morrer" como espectador e "sair fora" da peça. Trata-se, portanto, de uma operação simbólica, de um "tratamento" sobre a plasticidade da realidade.

\footnotetext{
montando a Wahb b. Munabbih. Ele não figura, no entanto, nas coletâneas consideradas como "canônicas" (...). (n. do trad.).

${ }^{56}$ Ibn 'Arabî, cit. e trad. por Chodkiewicz, in Océan, p 46.

57 O leitor encontrará, em francês e inglês, considerações mais aprofundadas sobre o tema nos livros de Michel Chodkiewicz, "Le Sceau des Saints" e "Océan sans rivage", op. cit.

${ }^{58}$ Ibn 'Arabî, Chatons, p. 638.

${ }^{59}$ Novamente, não há uma percepção sutil, nem um órgão de percepção sutil. Cada autor, em diversas passagens, refere-se a conjuntos variáveis de "órgãos" e "percepções das sutilezas" (lataif).
} 
Agora, eis um aspecto importante da metáfora: a contemplação da obra é também a contemplação de seu autor. Portanto, não se trata de dizer que a peça é apenas ficção, diferente da realidade. Não se trata de anular Hamlet para ver Olivier, pois sem a personagem, não veríamos a maestria do ator.

Nesta perspectiva, o mundo, os homens, os acontecimentos são as formas pelas quais cada um contempla a Maestria do Autor pois "...a cada dia, Ele se ocupa de uma [nova] obra." (Cor, 55:29)."

Esse algo tão maior, que define o coração "capaz de Deus" (e capaz, portanto, de conhecer o "final da peça Hamlet" ou mesmo de criar o final que quiser) não pode, a rigor, ser experimentado por ninguém que não seja um místico e, seja isso uma ferida narcísica para "nós", "ocidentais" contemporâneos ou não, a questão está fora de contexto aqui. Como disse, o que me interessa da Mística não é a sua dimensão inatingível mas, sim, o que dela posso extrair para pensar questões atuais e, especificamente, da Educação.

É importante agora rever essa metáfora do ator. Na peça, Hamlet é inimigo de Cláudio, mas, terminada a encenação, Olivier já pode ir, por exemplo, jantar com o ator que deu vida a Cláudio. A oposição entre ambos "deixou de existir" porque a realidade é outra. Trata-se de um sujeito plástico vinculado a uma realidade plástica.

Há dois "tipos" de Corão (note o leitor, esta é uma dualidade): o Corão percebido pelo ego e o percebido pelo coração. O que é percebido pelo coração produz uma constante "descida" ou "revelação" e implica em "gozo". Podemos "ler" esta idéia do seguinte modo: o Corão não é um livro simbólico, ele é o Simbólico. Por Simbólico entendo uma estrutura que pode ser sempre outra, e outra, e outra. Essa pura alteridade permite que o "novo" o impensável, o único, o imprevisto, o misterioso, etc. - se ponha como efeito não de um simples jogo combinatório, não da estrutura em si, mas de uma relação entre o coração e aquilo que o ultrapassa. Na realidade, esse "novo" não pode ser chamado de efeito de modo algum. Tampouco de rastro ${ }^{61}$. Mas ele pode, sob certos aspectos, ser visto como rastro.

Aqui é preciso fazer um parêntesis. A partir de Saussure, não dizemos mais que a linguagem é aquilo que expressa ou representa o pensamento mas, sim, que ela é pensamento. Nesta perspectiva, no caminho da desconstrução da idéia de unidade levada a cabo pelo pensamento contemporâneo, não há mais o "Um" que se expressa por meio do múltiplo (as palavras, a Revelação), isto é, não há um Deus fora, além, da Existência e, com Lacan e Derrida, não há um Deus além da Escrita, de tal modo que já não falamos mais em "Mundo" ou "Existência", como entidades, mas, sim, em Escrita, como marcas, diferença e movimento.

Em Ibn 'Arabî, o Real é tanto "Um" quanto múltiplo. A tradição corânica coloca para todo

\footnotetext{
${ }^{60}$ Sentidos do Caleidoscópio, op. cit., p. 99-100.

${ }^{61} \mathrm{O}$ termo aqui remete ao pensamento de Derrida.
} 
fiel uma série de Nomes divinos a partir daqueles com os quais Deus nomeia-se ao longo da Revelação: al-Waddud (o que ama), al-Sabur (o Paciente), al-Alim (o que conhece), alGafur, (o Perdoador), al-Zâhir, (o Exterior), al-Bâtin, (o Interior), etc. A série mais usual é a que contém 99 Nomes divinos. Nessa medida, o Um não se encontra além do múltiplo, pois ambos são aspectos de Deus.

Podemos, portanto, igualmente falar em diálogo entre Deus e o homem por meio da linguagem, como falar em diálogo no qual Deus é escrita e o homem é fala, ou diálogo no qual o homem é escrita e Deus é fala, ou diálogo de Deus com Ele mesmo por meio do homem, etc. Fecha parêntesis.

O que poderíamos chamar "o ternário: Deus, homem, mundo" é apenas um ternário, isto é, uma montagem, uma síntese, não se trata de essências ou de entidades. A "existência", o "mundo", a "criação" são termos filosóficos dos quais Ibn 'Arabî se apropria para trabalhá-los dentro de montagens que assumem as mais diversas formas (que não são, portanto, conceitos) conforme a "estação", a "presença", a "morada", o "Nome divino", etc. a partir dos quais ele fale.

Como vimos (cap. 1.4), a realidade, pelo seu aspecto "denso", é imaginação e, pelo seu aspecto "fluido", é escrita. Como escrita, é feita de estruturas maleáveis e vazias, montáveis e desmontáveis, apreensíveis e inapreensíveis, compreensíveis e misteriosas, previsíveis e surpreendentes, rigorosas e imprevistas, etc. Portanto, Deus é escrita e Deus é fala, assim como o homem e o mundo. Ou, para dizer a mesma coisa sem montar um ternário e ficando apenas no múltiplo: uma borboleta é escrita e é fala, um clips, uma coca cola.

"O universo é um livro, um "grande Corão", segundo uma fórmula já citada. Reciprocamente, o Livro é um universo. Falar de um é falar do outro.

Entre estes dois universos - ou dois Livros - há um intermediário: o homem - trata-se, evidentemente, do insân kâmil ${ }^{62}$ - que participa da natureza de um e de outro (ele é "irmão do Corão" e é também 'alâm saqîr, "pequeno mundo", microcosmo). É a ele que se dirige o discurso divino sob essa dupla forma, é a ele que cabe decifrar este discurso, de ser ao mesmo tempo tarjumân al-qur'an e tarjumân al-'alâm, o intérprete do Corão e o intérprete do mundo criado, aquele que Ihes dá sentido. A manifestação universal é o desdobramento dos âyât Allâh, dos "sinais de Deus" (mas igualmente dos "versículos", tendo a palavra "âyât" um e outro significado). Esses âyât são constituídos de "palavras", kalimât, que por sua vez são constituídas por letras, hurûf, que, num certo sentido, são as partículas elementares do Livro revelado. De onde a superposição das duas hermenêuticas, a do Corão, a do universo, que sublinha o paralelismo entre as vinte e oito letras do alfabeto e os vinte e oito graus (marâtib al-wujûd) da cosmologia akbariana."63

\footnotetext{
${ }^{62} \mathrm{O}$ "Homem Perfeito".

${ }^{63}$ Chodkiewicz, Illuminations, p. 51-2.
} 
Como intérprete, o homem é quem dá sentido aos âyât, porém, e isso é crucial, o sentido dado pelo ego é diferente do sentido que "desce" ao coração. Como eu havia afirmado no capítulo 1.4, a produção de sentido é uma experiência atual dentro de um campo total. Vejamos isso com mais detalhe.

Não é possível que o universo se subdivida em coisas vivas e coisas que não o são. Para nós, ele é vivo em totalidade. Tratando, no cap. 558, do Nome divino AlMuhyî, o Vivificador, ele escreve ainda: É Ele quem dá a vida a todas as coisas pois não há coisa que não esteja viva já que não há coisa que não louve a Deus: ora, somente os vivos - sejam eles vivos ou, segundo nossa percepção, mortos podem louvar a Deus. Não faltam referências escriturárias para esta noção de louvor pela totalidade das criaturas, ainda que sejam inertes a nossos olhos (Ibn 'Arabî refere-se geralmente a esse respeito à sura 17:44). Veremos, no entanto, que não temos aqui uma sutil exegese. Num outro de seus livros, o Rûh al-quds, Ibn 'Arabî, citando uma fala do Profeta relativa ao monte Uhud (Esta montanha nos ama e nós a amamos), acrescenta: Mesmo os minerais, para nós, conhecem Deus... eles constituem uma comunidade como todas as outras, afirmação explicitada por diversas confidências recolhidas nos Futûhât (Ouvimos, no começo de nossa vida espiritual, as pedras glorificando Deus e $O$ invocando), ou a alusão revelada acima de sua união nupcial com as estrelas e as letras do alfabeto. Trata-se, portanto, de uma percepção imediata da realidade secreta das coisas e não de um conceito elaborado por meio de uma reflexão sobre os textos. Com tal certeza, Ibn 'Arabî afirma então, e não é este um dos aspectos menos singulares da doutrina exposta no cap. 2, que as letras, elas também, constituem uma "comunidade" (umma), que elas possuem, elas também, seus Enviados (rusul), sua Lei (shari'a), que se distinguem entre elas o "comum" (âmma), a elite, a elite da elite como nas sociedades humanas. Quando ele trata do dâl ou do jîm e da predominância neles de tal qualidade, de tal temperamento, são seres que ele descreve e não signos abstratos. ${ }^{64}$

A "realidade secreta das coisas" - que o ego não pode perceber - é que elas estão vivas porque louvam a Deus. Isto é, a vida consiste no louvor. E o que é o louvor?

Um outro hadit qudsi ${ }^{65}$, frequentemente citado por Ibn 'Arabî e não reconhecido como "canônico" pelos doutores da lei islâmicos, diz: "Eu era um tesouro escondido, desejei ser conhecido, por isso criei as criaturas a fim de ser conhecido por elas". O louvor a Deus é, portanto, o conhecimento de Deus assim como a razão de ser das criaturas é esse conhecimento. Cada criatura conhece Deus a seu próprio modo e seu modo de existência é seu modo de conhecimento e seu modo de conhecimento é seu louvor. Conhecer o louvor das criaturas é conhecer o seu conhecimento. Ora, como vimos, na perspectiva sufi, qualquer conhecimento é conhecimento de Deus porque Deus é o ser de todas as coisas. Assim, to-

\footnotetext{
${ }^{64}$ Chodkiewicz, Illuminations, p. 50-1.

${ }^{65}$ Qudsi = sagrado, a expressão Hadit Qudsi designa as falas transmitidas pelo Profeta em que Deus expressa-se na $1^{\mathrm{a}}$. pessoa.
} 
das as criaturas estão vivas porque estão permanentemente conhecendo e nossa maneira de conhecer esse conhecimento é escutar o que o universo nos diz, isto é, seu secreto louvor.

Segundo uma tradição ${ }^{66}$, o louvor é o que estabelece a linguagem humana.

Deus "começou a criação do homem com a argila... Então, Ele o formou harmoniosamente e nele soprou de Seu Espírito" (Cor, 32: 7-9). O primeiro homem, então, pronunciou suas primeiras palavras - as que estabeleceram a linguagem humana - dizendo: al-hamdu li-llâh rabbi l-'âlamîn ["Louvado seja Deus, o Senhor dos Mundos"].

As mesmas palavras constituem o segundo verso da Fâtiha, a sura [capítulo] que "abre" o Corão e que, por esta razão, é frequentemente chamada de sûrat alhamd (a sura do louvor). Em cada uma das 5 orações rituais, cada muslim [muçulmano] recita a Fâtiha várias vezes, ecoando, desse modo, as falas de Adão até o fim dos tempos. ${ }^{67}$

O louvor do homem, seu modo de conhecimento de Deus, é a linguagem. O ego, por meio da linguagem, produz o conhecimento imaginário acerca das coisas, este que pensa as coisas como realidades em si. O coração, por meio da mesma linguagem, produz o conhecimento simbólico, este que cria as realidades a cada momento.

Se chegamos a estabelecer uma dualidade estrutural para a linguagem, na qual o significante veiculava um significado, e essa dualidade foi desconstruída, entre outros, por Lacan e por Derrida, aqui, em Ibn 'Arabî, a idéia ganha outra perspectiva pois,

A letra (harf) de uma coisa é sua dimensão manifesta, o "significado" (ma'nâ) é sua dimensão não manifesta. Em síntese, "o mundo é integralmente uma letra que veio a expressar um significado. Seu significado é Deus... portanto, o significado nunca cessa de estar conectado à letra: Deus diz, "Ele está convosco onde quer que estejais" (Cor, 57:4). ${ }^{68}$

Assim, a significação não é um processo paralelo à realidade. Ela não se refere à experiência segundo a qual alguém diz: "eu amo esta rosa" como se estas palavras em nada afetassem a realidade da rosa. Ao contrário, os processos de significação são os de realização. Dizer (e escrever) é ser.

Não é preciso dizer que, para nós, gente do desencantamento, tais considerações parecem inverificáveis na experiência comum. O que procuro asseverar, no entanto, é que podemos verificar experiências análogas. Se a Psicanálise não possui ferramental epistemológico para assegurar que todas as realidades estejam submetidas à Palavra, pelo

\footnotetext{
${ }^{66}$ Tabarî, Tar'îkh, Cairo, undated, I, 47; Tha'labî, Qisâs al-anbiyâ', Cairo, 1371 AH, 18.

${ }^{67}$ Chodkiewicz, The Banner of Praise, op. cit.

${ }^{68}$ Ibn 'Arabî, cit e trad por Chittick, in Meccan Revelations, op. cit., p. 241.
} 
menos, é impecável na sua demonstração de que a vida intrapsíquica é inteiramente afetada por ela:

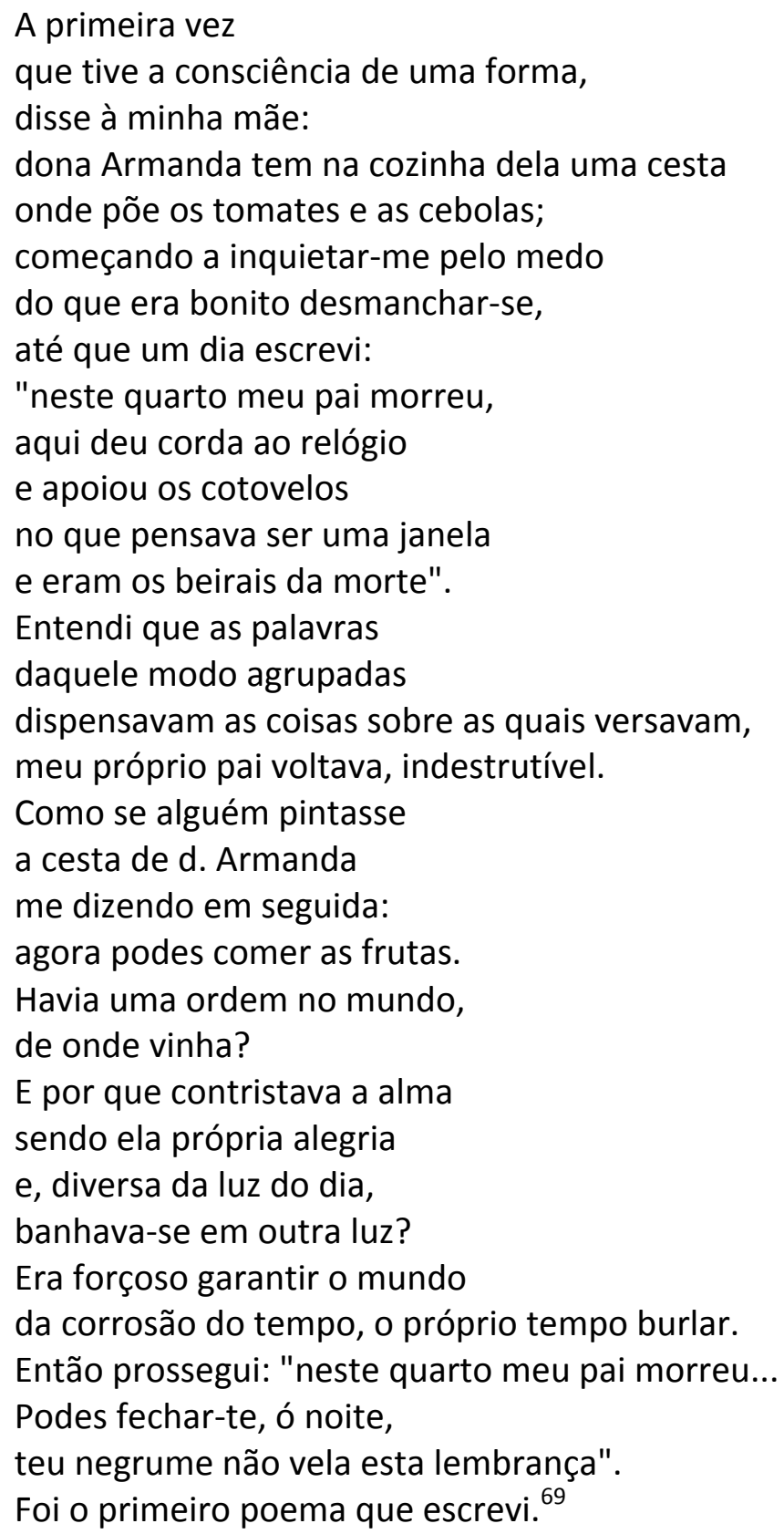

A língua portuguesa é uma totalidade no sentido de que, com ela, podemos dizer tudo o que quisermos. Embora totalidade, ela é perfeitamente distinta do francês e estas línguas não se confundem nem se misturam. Claro que está que podemos dizer a mesma coisa

${ }^{69}$ Adélia Prado, Obras Completas, op. cit., p. 314. 
tanto em francês quanto em português, porém, se a letra é diferente e se "Deus nunca cessa de estar conectado à letra", quer dizer que uma coisa dita em português nunca será a mesma se dita em francês pois "...a cada dia, Ele se ocupa de uma [nova] obra." (Cor, 55:29). O significado secreto das coisas, isto é, sua singularidade, reside nessa diferença: cada coisa, isto é, cada letra, tem o seu modo próprio de louvor.

Do mesmo modo, um signo do zodíaco, se for tomado como linguagem, é uma totalidade que não se mistura com a totalidade de outro signo. Nesse caso, "Touro" não significa "bens materiais", "riqueza", "bom gosto", etc., como quer a ciência positivista moderna que atualmente conhecemos como astrologia. Como qualquer língua, "Touro" significa qualquer coisa, diz qualquer coisa. E o diz de um modo diferente do de "Gêmeos" ou "Sagitário". Esta seria uma astrologia própria do alâm al-mitâl.

O homem, como intérprete do signos do mundo, não é alguém que produz significados subjetivos. A produção humana, desde Adão, possui uma "objetividade" encantada, difícil de captar com os sentidos do ego ${ }^{70}$. Não obstante, é possível propor uma "astrologia análoga", tratável pelo ego. Não porque a astrologia seja especialmente interessante aqui mas porque a idéia de uma interpretação da realidade é fundamental para a construção que se esboça.

O universo é uma totalidade não abstrata, viva, cuja fala - o louvor permanente a Deus - é a Escrita que fornece as marcas e a diferença para todas as escritas e todos os louvores que se comunicam analogicamente de modo a manifestar eternamente todas as diferenças e todas as totalidades. O universo é, portanto, uma totalidade de totalidades diferentes. E é o homem, com sua capacidade de criar línguas e, portanto, traduções, quem fornece os trânsitos por essas totalidades.

No Corão, Adão recebe os Nomes com os quais deverá nomear as coisas (Cor 2:31). Não se trata - com diversas implicações - do Nome do Pai porque Deus não é pai: "...não engendrou nem foi engendrado" (Iam yalid wa lam yulad, Cor, 112:3). Nomear significa, a cada momento, evocar os Nomes divinos que presidem cada realidade.

Quando te encontras num estado qualquer, celeste ou terrestre, estás necessariamente sob o regime de um dos nomes divinos, que o saibas ou não, que o contemples ou não. É este nome que rege teu movimento e teu repouso, é por ele que tens o estatuto de possível ou de existente. ${ }^{71}$

Não cabe no contexto analisar os termos técnicos presentes na citação acima, importa-me ressaltar que, aqui, o ato de nomear não é o mesmo que a "nomeação" feita pela menina do capítulo anterior, que encerrou sua experiência no diminuto cofre da palavra "triste".

\footnotetext{
${ }^{70}$ Não pense o leitor que caminho com os passos de Husserl, apenas utilizo as idéias de subjetividade e objetividade para estabelecer vias de acesso entre nossos hábitos mentais e o Encantamento, para o qual a divisão sujeito e objeto não se dá deste modo.

${ }^{71}$ Ibn 'Arabî, cit. e trad. por Chodkiewicz, in Océan, p. 138.
} 
Perguntaram a Mâlik b. Anas ${ }^{72}$ : Qual é tua opinião sobre a licitude da carne do porco d'água [hinzîr al-mâ: expressão que designa os cetáceos em geral ou, mais precisamente, os golfinhos]? Ele respondeu [fa-aftâ: trata-se de uma responsa jurídica e não de uma simples troca de réplicas] que era ilícita. Objetaram-lhe: Este animal não faz parte dos animais marinhos [literalmente "peixes" cuja carne é lí-

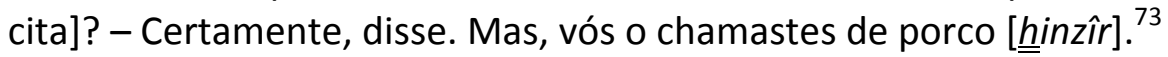

A "coisa" golfinho é impensável por si mesma, é o seu "nome" que rege sua "posição" na cadeia simbólica. A carne do nome "porco d'água" é ilícita, mas a carne do nome "golfinho", não. A palavra condena, a Palavra redime. ${ }^{74}$

Assim, o coração é o órgão da singularidade, isto é, da revelação permanente e, portanto, do conhecimento atual.

Se o homem pode "conter" a unidade, e a Revelação está destinada a este continente, quer dizer que o diálogo entre Deus e o homem, posto pelo Corão, é, nas palavras de Ibn 'Arabî, uma conversa de Deus com Ele mesmo.

Com toda a evidência, o jogo entre identidade e alteridade se torna total, há distinção e não distinção, dualidade e não dualidade, há identidade única e alteridade radical. Portanto, não se pode aqui falar em essencialidade, nem em unidade como sinônimo de identidade, como quer a tradição filosófica desconstruída e criticada por Derrida.

O emblemático poema de Ibn 'Arabî promove essa incomensurável abertura.

Meu coração tornou-se capaz de qualquer forma, pasto para gazelas e convento para o monge

e um templo para ídolos e Ka'aba para os peregrinos

e as tábuas da Torah e o livro do Corão.

Eu sigo a religião do Amor: qualquer caminho que tomarem

os camelos do Amor, eis minha religião e minha fé. ${ }^{75}$

\footnotetext{
${ }^{72}$ Grande jurista do sec. VIII, fundador da escola jurídica Malikita.

${ }^{73}$ Ibn 'Arabî, cit. e trad. por Chodkiewicz, in Océan, p. 39.

${ }^{74}$ Sentidos do Caleidoscópio, op. cit., p 147.

${ }^{75}$ Ibn 'Arabî, Tarjuman al-Ashwaq, XI, 13-15, trad. Nicholson, p. 67.
} 


\section{PARTE 2: PROBLEMAS DA SINGULARIDADE}

Saúdo meu Profeta e que a Paz de Deus esteja com ele tantas vezes quantas o ventre do céu carrega de estrelas

(canto popular marroquino)

Je salue mon Prophète et que la Paix de Dieu soit sur lui autant de fois que le ventre du ciel porte d'étoiles. 


\subsection{ESPAÇO PÚBLICO E REVELAÇÃO}

A tradição filosófica costuma opor o ideal republicano, de que os homens podem governar a si próprios, tendo como princípio a virtude e objetivando o bem comum, ao regime em que os homens são governados por um Deus transcendente, que está fora da realidade dos homens, e por uma lei exterior, divinamente revelada. Na república, tanto quem manda quanto quem obedece é, idealmente, um servidor - da virtude, do bem comum enquanto, por exemplo, no regime teocrático que caracterizou em seus primórdios os "Povos do Livro", quem manda (por exemplo, o rei ou a igreja) e quem obedece é, idealmente, um servidor - da Lei e da vontade de Deus. Como, entre os Povos do Livro, Deus não circula pelas ruas nem frequenta os mercados, sua vontade e sua lei devem ser interpretadas pelos homens, no caso, os poderosos, o que, na prática, faz de um regime teocrático um modelo de despotismo e da idéia de transcendência uma espécie de mentira simbólica.

Há quem sustente que a "mentira simbólica" é necessária e, sob muitos aspectos, saudável, pois permite a união dos homens por meio de algo "superior", o que lhes garante uma "identidade grupal", um vínculo por meio do qual os conflitos entre os homens possam aparecer sem quebrar ou cindir a sociedade (ou comunidade). Igualmente, há quem sustente que "um pouco de espiritualidade" é fundamental para afrouxar os nós sufocantes do exacerbado racionalismo moderno e para aproximar o homem "do coração" que possui, no dizer de Pascal, "razões que a razão desconhece".

A lógica que orienta tais considerações é a mesma: há algo de transcendente, fora da vida humana, fora dos conflitos humanos, fora da razão humana que, embora imaginário ou mentiroso, seria útil para, numa equação antagonista, equilibrar o peso das vicissitudes e do esforço sacrificial da vida guiada pela razão.

Em contrapartida, a crítica que se faz a esta visão propõe que o homem não precisa de nada "fora", que ele possui, idealmente, em si mesmo, como indivíduo, e na política, co- 
mo ação e instituição, os meios para superar seus desafios e constituir uma sociedade harmoniosa e justa ou que, pelo menos, se a luta for por uma meta inalcançável, que essa meta seja imanente e não transcendente. Nesse contexto, a palavra "revelação" é a meIhor síntese de tudo o que os homens não precisam, seja como ferramenta de um poder de opressão, seja como mentira ou ilusão infantillizadora e inibidora da capacidade dos homens de resolver seus próprios problemas.

A perspectiva sufi subverte essas noções. Em primeiro lugar, no sufismo, cada homem em particular é o intérprete da revelação.

Como vimos, Deus é Um e Um para cada um. "A cada um de vós, demos um caminho e uma via" (Corão, 5:48), diz uma das inúmeras referências escriturárias que os sufis utilizam para produzir tecnicamente essa experiência singular. Comentando o verso corânico: "Não é dado a nenhum homem que Deus se dirija a ele a não ser por revelação ou atrás de um véu ou enviando-Ihe um mensageiro." (Cor, 42:51), Ibn 'Arabî nos diz:

"A Revelação é tanto o que Ele projeta nos corações de Seus servidores, sem intermediário, e Ihes faz ouvir neles mesmos, tanto o que Ele diz ao servidor sob o véu de uma forma qualquer pela qual Ele Ihe fala (...) tanto o que Ele lhe diz por intermédio de um mensageiro." ${ }^{76}$

Em segundo lugar, esse homem não é intérprete exclusivamente por meio da consciência ou daquilo que ele "sabe de si e dos outros", pois essa interpretação realiza-se por meio de capacidades supraconscientes ou "sutis" - como vimos acima -, o que implica uma diferença profunda entre o sufismo e, por exemplo, duas perspectivas modernas que pensam a interpretação como ação da subjetividade: o protestantismo e o romantismo. 0 processo interpretativo no Sufismo não se realiza por meio de uma atividade mental e a questão não está em buscar o "espírito da letra". Trata-se de algo muito mais complexo. Do que não se deve entender, no entanto, que as operações interpretativas sejam feitas à exclusão da razão, ou da imaginação, ou da emoção, etc.

Em terceiro lugar, no sufismo não há fora. E esta não é uma de suas características, é seu fundamento. Deus é um e Deus está em todas as coisas. A frequente acusação de panteísmo dirigida aos sufis não se dá conta das implicações tão mais graves que este encerra: Deus é todas as coisas, portanto, cada "coisa", em particular, é Deus. Significa ter um olhar múltiplo sobre a "realidade". Além disso, o sufismo não pode ser identificado exclusivamente nem à transcendência, nem à imanência, pois ambas são igualmente utilizadas operativamente pelos sufis conforme os mais diversos contextos, como, igualmente, vimos acima.

Em quarto lugar, não há necessidade de mentira e a expressão "mentira simbólica" é uma contradição de termos, como veremos quando eu abordar o simbólico.

\footnotetext{
${ }^{76}$ Ibn 'Arabî, cit e trad por Chodkiewicz, in Océan, p. xx.
} 
Finalmente, há uma relação de outra ordem entre a república e a perspectiva aqui focalizada. A idéia de "bem comum", prioritariamente racional na república, é representada por um espaço público que é o mesmo para todos. Na república moderna, diferentemente da romana, o espaço do indivíduo é excepcionalmente maior e a idéia de bem comum inclui o estado de direito e o asseguramento dos espaços individuais, vistos em larga medida como enriquecedores do espaço público por meio das artes, do empreendedorismo, dos dramas psicológicos individuais. A subjetividade não é apenas uma marca do indivíduo, ela é o grande campo das histórias individuais, que valem a pena ser contadas e o são de fato, tornando o espaço público, na Modernidade, mais povoado de gente que de anjos (Idade Média) ou mitos (Roma). Povoado, portanto, das paixões, dos acontecimentos, dos novos tipos de prazer e de sofrimento, que não se referem, como no espaço religioso, à busca da salvação exclusivamente, mas que reportam as vicissitudes dos homens frente às descobertas científicas, aos direitos e à nova lei que regula a vida mundana, frente à nova liberdade: pode-se escolher a própria profissão, o próprio casamento, a religião, os estudos. Evidentemente, há um preço a pagar pela nova equação: se a república visa o bem comum, como conciliá-lo com os desejos individuais? Se, historicamente, o desejo individual - incluindo-se o "pecado" ou a "vileza" - foi considerado pelos modernos um impulso necessário ao desenvolvimento da sociedade, a educação torna-se um dos principais veículos de "conversão" dos desejos individuais em desejos que, em alguma medida, correspondam ao bem comum. É necessário, então, que o bem comum seja prazeroso e realizador e, inversamente, é necessário que os indivíduos aprendam a tolerar frustrações e a mediatizar seus desejos. Há meios para se fazer isso e podemos pensar numa escala que inclui desde os meios mais grosseiros até, digamos, os mais sofisticados. De um modo geral, os "grosseiros" seriam aqueles que tiveram a primazia na sociedade capitalista, na qual o indivíduo, que pareceria, a princípio, muito mais livre que na república romana, é vigiado e punido, na qual a recompensa e o castigo - que deveriam ter sido abandonados num regime que visaria à desinfantilização dos homens, doravante tornados governantes de si próprios - são a estrutura mesma da construção da subjetividade, este latifúndio variado, rico, porém, rigorosamente circunscrito e controlado do espaço individual. A ordem e o progresso tornam-se os pilares da construção do bem comum. O indivíduo é livre, no entanto, gradativamente, vai sendo capturado no emaranhado das identidades forjadas sob o véu da ideologia, vai se tornando cada vez mais dependente das construções imaginárias que definem a priori suas experiências até que finalmente, na pós-modernidade, passa de indivíduo a consumidor, sua liberdade fundamental sendo a liberdade de escoIher o que comprar. O bem comum sendo os bens de consumo.

Evidentemente, há espaços de ruptura desses discursos nos quatro cantos do planeta. Eles correspondem a lugares, em maior ou menor escala, de renovação, de respiração, ou, pelo menos, de tentativas de manutenção da coesão perdida do self government e do bem comum. Antes de falar disso, porém, é necessário ainda prosseguir nesse diálogo com a república moderna.

Na idéia de revelação - que define a mística por excelência -, o que pode ser tratado como análogo ao lugar do "bem comum" republicano é a vontade de Deus. Uma implicação 
disso é que a vontade de Deus não pode ser definida a priori. Expressa numa Lei revelada e "fixada" num Livro, ela é um caleidoscópio em constante mutação, conforme o tempo, o lugar e as pessoas ${ }^{77}$. Obviamente, a "vontade" divina interpretada, por exemplo, pelos doutores da lei islâmicos ou da Igreja é inteiramente definida a priori - motivo pelo qual os doutores da lei são tão criticados pelos místicos - e isso a distingue fundamentalmente da Vontade simbólica, essa que é "vazia" e é "projetada nos corações", como vimos. Além disso, a relação de cada fiel com a palavra revelada - provavelmente reduzida ao mínimo em nossos dias - foi exercida em diferentes níveis, conforme os graus variados de conhecimento dos fiéis muçulmanos. Algo, não obstante, era comum a todos.

Não posso, no contexto, fazer um estudo comparativo entre a república moderna e a 'umma ${ }^{78}$, o que seria desejável, porém, foge ao escopo desse trabalho. No entanto, em linhas gerais, é possível esboçar uma espécie de história simbólica da 'umma, segundo o foco do que me interessa particularmente aqui.

Estudar o desenvolvimento das artes, das ciências e da cultura islâmica durante os 5 séculos de seu início é uma experiência de perplexidade, não apenas pelo porte extraordinário desse desenvolvimento mas, também, pela forma como esse Período foi, de variadas formas, ocultado após a Reconquista espanhola ${ }^{79}$.

O que sobrou desse vigoroso e inovador Islam, parte constitutiva e fundamental da "sociedade ocidental judaico-cristã", é o "inimigo", o "exótico", o "atrasado", o "incompreeensível" "povo" cuja face em nada se assemelha nem a "nós", nem ao seu próprio passado. Mas, o Islam foi parte de "nós" e muito - muito mais do que suspeitamos - de nosso "progresso" deve-se à civilização corânica. Chamo a atenção, a fim de abreviar o que seria um longo caminho, para a arte islâmica presente na Ásia, na Pérsia, no norte da África e na Península Ibérica, nestes 5 séculos.

Dos azulejos na Alhambra, com versos do Corão em diversos tipos de caligrafia e seus detalhes e a técnica arquitetônicos, aos jardins em torno das mesquitas e das tumbas de santos na Rota da Seda; a combinação dos padrões geométricos, dos desenhos e das cores, numa palavra, o espaço físico público na pequena Sevilha ou na grande Bagdá era um lugar de exigência intelectual: não havia distinção entre o funcional, o decorativo e, diríamos hoje, o significativo; tudo no entorno era a expressão de uma ciência que acontecia na contemplação e no uso diário desse espaço. E isso é inteiramente crucial: não se tratava, para um muçulmano "comum", de saber essas ciências, de conhecer - como "nós" entendemos a idéia de conhecer - a construção de um padrão geométrico ou as suas implicações aritméticas, alquímicas, médicas, arquitetônicas ou teosóficas. A convivência e o acoplamento com essa riqueza harmônica e complexa realizavam uma pedagogia de cará-

\footnotetext{
77 Tratei desta questão de modo mais extenso no meu livro "Sentidos do caleidoscópio...".

${ }^{78}$ Termo árabe que pode ser traduzido, na sua acepção histórica, por "comunidade" e que representa o conjunto daqueles a quem a revelação fala.

${ }^{79}$ Ver a respeito: Juan Vernet, "Lo que Europa debe al Islam de España", Titus Burckhardt, "Arte Sagrada no Oriente e no Ocidente", Roger Garaudy, "Promessas do Islam", obras citadas.
} 
ter integral. Não só a mente, mas os sentidos e o corpo como um todo, integrado a um espaço recortado, qualificado, porém não fechado mas, que, ao contrário, abria-se ao infinito das irrepetíveis combinações entre os elementos - que "nós" chamamos coisas postos como palavras e frases de um único, fluido, maleável e surpreendente Discurso, um corpo capaz de tal Discurso - capaz de recebê-lo, de sustentá-lo e de incorporá-lo -, um corpo em interação, igualmente ouvinte e falante, um corpo inteiramente inteligente era o alvo dessa pedagogia.

A prática da cortesia - o termo em árabe é 'adab, que também pode ser traduzido por ética - não por acaso, era a prática desta harmonia posta nas relações: hospitalidade, acoIhimento, mansuetude e generosidade, pois o outro é parte de uma composição na qual tudo se inclui porque a harmonia não é algo que se acrescenta ao espaço, ela lhe é constitutiva.

Não se apresse o leitor em crer que, por obra de um pensamento mágico do mundo encantado, eu eliminei do espaço público sunita ${ }^{80}$ a injustiça, a opressão, o abuso de poder, a vaidade, a corrupção, a estupidez ou a ignorância. $O$ que me interessa aqui é que a lente mística nos permite ver um tipo de pedagogia e uma relação com o conhecimento que, se, obviamente, não explica, há de ser, pelo menos, significativamente importante no entendimento tanto do vigor do desenvolvimento islâmico quanto da efetividade de sua subsequente "ocultação" na História.

No direito islâmico, a terra pertence a Allâh de fato e seu usufruto é dado ao homem que, para "merecê-la", deve trabalhá-la. A propriedade privada, tal como a concebemos, não se aplica ao modelo da 'umma. O direito aparece, sob vários aspectos, combinado à ética e à política. O espaço público, aqui também, está estruturado na mesma perspectiva. Em tese, o objetivo das leis não é o de assegurar a ordem - porque a desordem ameaçaria o comércio e, em seguida, o desenvolvimento industrial, como na experiência "ocidental" mas, é o de assegurar o cumprimento da vontade de Allâh e essa vontade, primordialmente, não é a vontade do bem, é a vontade do conhecimento. "A pena do sábio é superior ao sangue do mártir", diz um hadit ${ }^{81}$ do Profeta. "Buscai o conhecimento nem que seja na China", diz outro. E, um hadit qudsi ${ }^{82}$, já citado, diz: "Eu era um tesouro escondido, desejei ser conhecido, por isso criei as criaturas a fim de ser conhecido por elas". Portanto, a razão de ser das criaturas - não apenas do homem - é o conhecimento de Deus. Como Deus é também cada "coisa" em particular e cada homem, trata-se também do conhecimento do mundo, do outro e de si mesmo - daí a ênfase no desenvolvimento das ciências e das artes no Islam.

\footnotetext{
${ }^{80}$ O termo "sunita" refere-se aos fiéis que seguem a sunna, o conjunto das práticas do Profeta.

${ }^{81}$ Hadit (lit.) = novo, novidade, nova (profética). Este é o termo que designa as falas do Profeta Muhammad, compiladas em coletâneas.

${ }^{82}$ Qudsi = sagrado, a expressão Hadit Qudsi designa as falas transmitidas pelo Profeta em que Deus expressa-se na $1^{\text {a }}$. pessoa.
} 


\subsection{ESPAÇO PÚBLICO COMO O ESPAÇO DA ESCRITA}

Essa convivência e esse acoplamento, termos que eu pus em itálico acima, não eram resultado de uma experiência passiva por parte do muçulmano "comum" (e aqui veremos como as considerações de Derrida sobre a primazia da fala sobre a escrita não se aplicam a estes homens). O Corão foi revelado em "língua árabe clara" (Cor., 26:195). Ao utilizar uma língua semítica, o Corão tem seu trabalho de construção simbólica incrivelmente facilitado. Vejamos.

"No árabe, diferentemente das línguas indo-européias, a combinação das letras produz não apenas sentidos mas, sobretudo, paradigmas. As palavras são formadas por raízes, em geral, de tres consoantes (encontram-se também, embora raramente, raízes de 2 ou 4 consoantes). Seus diversos sentidos surgem a partir das modificações sobre a raiz, pelo acréscimo de vogais, de prefixos, sufixos, etc.

Por exemplo, tome-se a palavra mâlik (= rei). O paradigma, isto é, a raiz, é formado pelas tres consoantes MLK. Se acrescentarmos a estas consoantes as vogais "a" e "i", temos o significado "rei". Conforme alteramos as vogais, alteram-se as palavras e obtemos novos significados: malaka (anjo), mulk (reino terrestre) e malakut (reino celeste)." ${ }^{13}$

O hábito "interno" de alguém que nasce ouvindo a recitação do Corão - numa época em que tal compreensão está vigente - é ouvir "em níveis". A polissemia corânica não é aleatória. Por ser paradigmática, ela é harmônica no sentido de ser uma estrutura harmônica. A escrita árabe, que explicita visualmente esses paradigmas em arranjos e combinações variadíssimas, posta como elemento de composição e de estruturação dos espaços, dá a dimensão do que o ignorante ocidente chama de "fatalismo árabe": maktub, está escrito. Tudo está escrito, não porque está determinado, mas porque faz parte de um arranjo, de um discurso, de uma inteligibilidade própria, ou, como diz Ibn 'Arabî, "não há nada no uni-

83 "Sentidos do caleidoscópio", op. cit., p. 121-2 
verso que não esteja certo" 84 . Longe de ser uma forma de forçar uma aceitação artificial das vicissitudes e mascarar as injustiças ou os conflitos, esta ênfase na harmonia, no "integral integrador", por assim dizer, resulta de um pensamento complexo.

Na obra de Ibn 'Arabî, podemos encontrar diversas abordagens em torno da idéia de harmonia e de suas implicações nos campos da ética, da política, da jurisprudência, da alma, etc. Citando versos do Corão, o mestre andaluz "demonstra" que, a rigor, não há politeísmo nem infidelidade, que o castigo do inferno não é eterno, que Muhammad foi enviado a toda a humanidade, inclusive àqueles que viveram antes dele, etc. O cerne da questão pode ser visto pelo ângulo de uma pedagogia mística: trata-se de ensinar os homens, cada homem, cada criança, cada um, a alargar-se ao longo da vida, a combater o enrijecimento e o apequenamento gradativo do ego. Esse combate se dá pela capacidade de, por um lado, esvaziar-se - basicamente, esvaziar-se do que, para usar um termo genérico, poderíamos chamar de condicionamentos ${ }^{85}$ - e por outro, de dirigir-se a outros lugares, encontrar outras posições, ver de outro modo, desenvolver outras concepções, criar para si outras histórias, construir modos diversos de relações, tornar-se mais capaz da vida - assim como da outra vida. Aprender é uma forma de meditar, o que se faz "fora", organiza algo "dentro" e, aqui, é preciso lembrar que estamos em uma época na qual o par "objetivosubjetivo" não se aplica, portanto, não é disso que se trata e, tampouco, a idéia de que algo "se organiza dentro" não é a mesma da que subjaz ao postulado ideológico de que "o trabalho enobrece o homem", tampouco esta organização interna corresponde a uma adequação dos homens, referenciados pelo "fora", à ordem social aceita. Esta meditação é uma operação de caráter técnico e não moral. O aprendizado da ciência - nome de algo muito diferente do que "nós" conhecemos como tal - é o meio pelo qual o homem pode, aos poucos, construir internamente essa capacidade de alargamento.

A "inclusão", possibilitada pela harmonia, não é, portanto, uma simples operação mental. O taclid, método pedagógico islâmico presente em escolas e nas tariqas ${ }^{86}$ e que pode, com ressalvas, ser traduzido por imitação, não consiste numa imitação visual. O termo que utilizei, acoplamento, visa resgatar esse caráter integral da imitação, é como se todo o ser da pessoa "entrasse" no ser da outra pessoa e fosse como ela, mas, não só isso, é como se fosse uma visitação periódica e constante que, a cada momento, obtivesse um conhecimento novo, único e integral e, ao mesmo tempo, um conhecimento que também fosse parte da construção de um processo de capacitação e de aprendizagem pessoal, em níveis diversos.

"Certamente, há para vós, no Enviado de Allah, um modelo excelente." (Corão, $33: 21)$

\footnotetext{
84 "Il n'y a rien dans l'univers qui ne soit pas droit". Traduzido para o francês por Chodkiewicz, in Océan, p. 63.

${ }^{85}$ Idries Shah utiliza o termo "condicionamento", inicialmente, a partir de Pavlov, para em seguida, contextualizá-lo em ambiente sufi e, dessa maneira, permitir que ele assuma uma amplitude "encantada".

${ }^{86}$ Ordens sufis.
} 
A idéia de modelo encerra a de matriz de significados. Com um sentido diferente da idéia platônica de modelo e mais ainda daquela criticada por Derrida como uma forma de centramento, o termo foi escolhido por causa de sua acepção corânica: o modelo é o que pode ser imitado. Se o modo religioso de pensar essa imitação consiste na reprodução piedosa dos atos do Profeta, no sufismo, imitar Muhammad é, antes de tudo, ser, como ele, o receptáculo da Palavra, é construir para si a capacidade de conceber novos e imprevistos significados.

Aquele cuja compreensão é idêntica, por ocasião de duas recitações sucessivas (do Corão), é perdedor. Aquele cuja compreensão é nova a cada recitação, é ganhador. Quanto àquele que recita sem nada compreender, que Deus Ihe tenha misericórdia! ${ }^{87}$

A imitatio prophetae, nesse caso, passa a ser um trabalho de meditação e de construção simbólica.

Portanto, não se trata de imitar o professor - ou os pais, ou as autoridades. Trata-se, por um lado, de imitar o Corão, naquilo que ele possui de letra ou estrutura ou multiplicidade, e, por outro, o Profeta, naquilo que ele possui de unidade, de presença ou atualidade. Dito de outro modo, pode-se fazer a imitação de um professor, de uma pessoa, ou mesmo de uma cadeira, de um livro, de um pássaro; o importante é que se trata de um modo de apreensão com o corpo, ou melhor, com uma totalidade articulada que inclui a atualidade de quem apreende. Não se trata de um aprendizado da harmonia, trata-se de um aprendizado harmônico.

Mergulhamos na Essência
e fizemos a viagem do corpo humano
Encontramos o curso dos universos
inteiramente no corpo humano
E todos esses céus que turbilhonam
e todos esses lugares sob essa terra
Esses setenta mil véus
no corpo humano descobertos
Os sete céus, os montes e os mares
e os sete níveis telúricos
O vôo ou a queda aos infernos
tudo isso no corpo humano
E a noite bem como o dia
e as sete estrelas do céu

Mergulhamos na Essência

e fizemos a viagem do corpo humano

Encontramos o curso dos universos

E todos esses céus que turbilhonam

e todos esses lugares sob essa terra

Esses setenta mil veus

no corpo humano descobertos

Os sete céus, os montes e os mares

O vôo ou a queda aos infernos

E a noite bem como o dia

e as sete estrelas do céu

\begin{tabular}{|l} 
As tábuas da iniciação \\
estão também no corpo humano \\
E o Sinai onde subiu Moisés \\
- ou então a Ka'aba \\
O Arcanjo soando o trompete \\
da mesma forma no corpo humano \\
A Bíblia e o Antigo Testamento \\
e os Salmos e o Corão \\
Todas as palavras escritas \\
encontram-se no corpo humano \\
O que diz Yunus é certo \\
confirmamos seus dizeres \\
Deus está onde o põe teu desejo: \\
todo inteiro no corpo humano."
\end{tabular}

\footnotetext{
${ }^{87}$ Ibn 'Arabî, cit e trad. por Chodkiewicz, in Océan, p 47.

${ }^{88}$ Yunus Emré, sec. XIII, poeta sufi, considerado na Turquia como um de seus maiores poetas.
} 
O mistério da natureza está inteiramente expresso na forma humana. O homem foi produzido do fundo do mais longínquo passado do planeta; ele traz em si, como seu próprio destino, todo o destino do planeta e, com este, o destino do universo infinito. Toda a história do mundo dorme em cada um de nós. ${ }^{89}$

Notemos o último verso do poema de Yunus: "Deus está onde O põe teu desejo: todo inteiro no corpo humano." Como veremos adiante, Deus, sob certos aspectos, está, virtualmente, em toda parte, mas quem decide onde Ele está atualmente é o desejo ${ }^{90}$.

Tudo isso é possível porque há escrita. O corpo é escrita. O templo é escrita. Assim como a sunna - o conjunto das práticas do Profeta, que dá a esta parte do Islam o nome de "sunita" - é escrita. E escrita, vale dizer, não quer dizer texto. Quer dizer estrutura harmônica sobre a qual constroem-se melodias variadas e sempre atuais. Isso é possível porque a escrita fixa um arranjo sobre o qual transitam múltiplos significados, como as vogais se movimentam "sobre" as consoantes, formando palavras diversas. A eloquente metáfora em torno do kitab, o Livro (o Corão), é que ele é a urdidura - a estrutura de fios verticais do tear onde são feitos os tapetes - sobre a qual podem ser tecidas quaisquer tramas - os desenhos e os formatos que tornam cada peça tecida uma forma única.

Utilizada tecnicamente, a metáfora da Trama e da Urdidura é um fundamento doutrinal. Em sua desconstrução do par saussuriano "significante-significado", Derrida nos faz ver o que me agrada chamar de "uma realidade em profusão": a idéia de um significante "fixo" unido a um significado "móvel" é desmontada pela idéia de múltiplos significantes em movimento e, finalmente, pela alteridade radical. O outro é inalcançável porque ele já não está mais aí, ele escapa, transcende. Entre os sufis, a trama é sempre outra, aparição fugaz do Outro porque a trama é outra que ela mesma. O que ela revela é igual ao que oculta, o que ela diz não esgota seu por dizer e nada pode fixá-la. Enquanto trama, a realidade escapa. Agora, a urdidura é fixa, e é fixa de modo diferente ao da "fixidez" do significante. A urdidura é a sustentação da trama. É essa sustentação o que permite que a trama exerça sua liberdade fundante de ser outra. No entanto, essa "fixidez" não é uma positividade, a urdidura é na verdade um sistema relacional, um sistema de diferenças. Digo novamente esta idéia, citando Marilena Chauí, dizendo Merleau-Ponty:

Não sendo um positivo, o Ser Bruto também não é um negativo, mas aquilo que, por dentro, permite a positividade de um visível, de um dizível, de um pensável, como a nervura secreta que sustenta e conserva unidas as partes de uma folha, dando-Ihe a estrutura que mantém diferenciados e inseparáveis o direito e o a-

\footnotetext{
${ }^{89}$ Rumî - grande mestre sufi, autor do Masnavi, considerado como "o Corão Persa" - cit e trad. por VitrayMeyerovitch, in Le Chant du Soleil, p. 18.

${ }^{90}$ O termo "desejo" não aparece, na Mística, com a sua acepção moderna e sua relação com uma idéia particular de destino, como mostra Marilena Chauí, in Desejo, cap. Laços do Desejo. Como sempre, o Sufismo possui variados termos, para dar conta de variadas nuances, daquilo que, numa visão genérica, chamamos hoje, sobretudo na Psicanálise, de desejo. Alguns termos da Mística podem ser traduzidos por "aspiração", "chamado", "vocação", "intenção", "energia espiritual", etc.
} 
vesso: é o invisível que faz ver porque sustenta por dentro o visível, o indizível que faz dizer porque sustenta por dentro o dizível, o impensável que faz pensar porque sustenta por dentro o pensável. O Ser Bruto é a distância interna entre um visível e outro que é o seu invisível, entre um dizível e outro que é o seu indizível, entre um pensável e outro que é o seu impensável. É um "sistema de equivalências" diferenciado e diferenciador pelo qual há mundo. ${ }^{91}$

E, note-se: não se trata aqui de propor uma dualidade e de fixar "os conceitos" de trama e urdidura. Trata-se de uma metáfora que opera, como toda metáfora, como trama e urdidura ao mesmo tempo. Na metáfora, há sempre esse deslizamento da trama, mas o deslizamento ocorre na estrutura da metáfora. A rigor, não há uma urdidura e uma trama. Conforme o contexto, uma urdidura pode ser "vista" como trama e vice-versa. Quando, na 1a. Parte, busquei traçar os contornos dos termos que utilizo - "encantamento", "místicos" e "sufis" - minha escolha foi precisá-los salvaguardando-lhes uma imprecisão. Agora, porém, posso "precisar": o termo "encantamento", por exemplo, será aqui utilizado como trama e como urdidura. Há um encantamento que sustenta uma série de discursos variados, vindos de homens e épocas variadas. E há diversos encantamentos, diferindo conforme o tempo, o lugar e os homens que o encantam. Na perspectiva aqui focalizada, ambos, trama e urdidura, são escrita. E a linguagem, na acepção aqui utilizada, é o conjunto das leis da urdidura. Mais adiante, essa metáfora da relação entre a trama e a urdidura é o que eu chamarei de simbólico.

O Corão, como urdidura, é um "guia confiável e seguro". Os homens não leem, eles caminham por suas vias. Como trama, ele é um acordamento das infinitas possibilidades de trama.

Se os tapetes são perenes e visíveis, são também um produto acabado, menos flexível. Em contrapartida, as melodias são efêmeras, intocáveis e incapazes de deixar algum rastro aos tempos vindouros, mas são pura atualidade, renováveis a cada momento. Pensando no cotidiano do fiel muçulmano dos anos de ouro do Islam, essas duas metáforas se combinam para nos dar uma vaga idéia do funcionamento das pessoas naquela época diante de seus espaços públicos: uma estrutura fixa vazia permitia variações em qualquer área do conhecimento humano, desde uma certa experiência interior, particular, vivida nas intimidades cotidianas até as elaborações complexas que precedem a construção de novos patamares científicos.

O termo "vazia" aqui é crucial: todo conjunto de leis - de uma sociedade, de uma instituição, de uma moral, de uma atividade grupal - é um conjunto de parâmetros que permite uma mobilidade relativa. No entanto, o que estiver fora dos parâmetros será, por definição, ilegal. A estrutura vazia, ao contrário, é totalmente inclusiva - daí a importância técnica das idéias de totalidade e de revelação - ela não possui "parâmetros", ela possui "símbolos", isto é, realidades que se ultrapassam.

\footnotetext{
${ }^{91}$ Marilena Chauí, Experiência do Pensamento, op. cit., p. 154.
} 
A urdidura simbólica das Mil e Uma noites é invisível a olho nu. Suas montagens e desmontagens, sem nenhuma moral, organizam o leitor em quem ela penetra, esvaziam-no e preparam-no para aprender. O processo, no entanto, não pode ser percebido de fora. As experiências de desejo e gozo entrelaçadas na urdidura simbólica da revelação são testemunhas silenciosas de uma liberdade sofisticada: a liberdade de conhecer-se.

O autoconhecimento, nesse contexto, tem um sentido diverso daquele a que estamos habituados. Conhecer a própria escrita é, antes de tudo, dialogar com as escritas com as quais se realiza um "acoplamento", é vibrar em harmônicos ${ }^{92}$. Não é um saber sobre si, é um escrever-se permanente. É, portanto, uma série de ações: conhecer o(s) outro(s) em modo atual, inventar realidades, ciências, construir novos possíveis. E é uma maneira particular de multidisciplinaridade.

Nesse caso, esse espaço público encantado, onde nada parece acontecer, no qual as relações parecem entre impessoais e pouco espontâneas, em que tudo, por uma certa ótica, parece proibido, é o mesmo espaço em que boa parte da criatividade científica que acreditamos ser exclusivamente "ocidental" foi gestada.

Note-se, porém, que de nenhuma maneira o que se pretende aqui é justificar qualquer aparente supressão dos direitos individuais, conquistados a partir da república moderna. O que me interessa aqui é aprender algo que, possivelmente, "nós" não sabemos.

Sem poder escolher um governante ou com quem casar-se, esses muçulmanos e essas muçulmanas atravessavam diversos processos, postos à disposição de todos no espaço público da 'umma, pelos quais "escolhiam", isto é, harmonizavam-se com modos de autoconhecimento. O modelo voltado para o autoconhecimento não é melhor que o modelo do "bem comum", nem o contrário. O julgamento dessa questão não pertence ao escopo deste trabalho. $\mathrm{O}$ que me parece importante aqui é que ambos são, em alguma medida, possíveis.

Por último, resta assinalar, para fechar este capítulo, que, se o espaço público na República é o mesmo para todos, na 'umma, ele é singular e, portanto, como vimos anteriormente, é um e um para cada um.

\footnotetext{
92 Numa definição genérica, o harmônico, em música, é um som que faz parte de uma nota ou de um acorde, porém, não é percebido pelo ouvido humano.
} 


\subsection{ESPAÇO PÚBLICO E IDENTIDADE}

Tomando como cenário o séc. $\mathrm{XX}$, o tema do singular poderia ser estudado de diversos modos a partir da filosofia. De Marx a Foucault, passando, por exemplo, pela Escola de Frankfurt, analisamos os processos pelos quais a sociedade capitalista e a instituição educacional roubaram aos homens a construção, na cena pública, [daquilo que o presente trabalho pretende chamar] de sua singularidade.

Igualmente, o tema poderia ser abordado pelo foco da psicanálise, com a radical singularização do sujeito do inconsciente, alheio, sob muitos aspectos, às máscaras de padronização social postas e impostas pela "consciência" individual.

Na pós-modernidade, a própria idéia de singularidade ganha outros contornos, afastandose ainda mais da experiência "habitual" do "homem comum".

Agora, levado ao campo da prática educacional e da instituição escolar propriamente dita, o tema escandesce em todos os seus problemas. Cada aprendiz aprende segundo um ritmo próprio, interesses próprios, funcionamentos, estruturas, história e, finalmente, linguagem próprias. Como educar cada um em sua unicidade? Além disso, o quanto dessa "unicidade" é realmente "singularidade?

Dito de outro modo, o quanto dessa "unicidade" não é simplesmente a produção de um "diferencial" individualista, calcado na necessidade de cada um de distinguir-se no mercado competitivo das relações?

Quando questionado por seus amigos sobre seus "delírios" a respeito de ser um cavaleiro, Dom Quixote responde: "Yo sé quién soy!" e acrescenta que isso não o impede de ser quem ele queira.

Por saber quem é, Dom Quixote sabe que pode ser qualquer um. Sua resposta não foi 
simplesmente que ele se sentia livre para ser quem quisesse, ela inicia por uma afirmação categórica de que ele sabe quem é, portanto, que é um. No entanto, pode ser outros uns. A unicidade, nesse caso, não equivale a um conteúdo fixo e positivo (não vazio).

A idéia de que "eu sou", como se houvesse uma unidade positiva, cuja natureza fosse independente dos acontecimentos é completamente impensável no meio acadêmico desde Nietzsche. No entanto, ela está presente nas conversas mais corriqueiras, nos discursos oficiais, nas campanhas publicitárias, nos jornais, na novela e na canção popular. E é essa idéia, do que normalmente se chama de "identidade", que me interessa particularmente aqui.

Assentada frequentemente em "atributos" fabricados na indústria cultural e distribuídos conforme os targets adequados, a identidade é a fantasia mais perene do cidadão destes últimos tempos. Não era assim na Idade Média, nem entre tribos shamânicas, na China ou na Índia antigas, nem nas chamadas Tradições Abrahâmicas. Passou a ser assim na Modernidade, com o surgimento do indivíduo e de toda uma construção viabilizada, conforme já mencionei, pela República. Claro está que aqui se coloca uma discussão que nos levaria muito longe da questão tratada, portanto, deixo-a para quem "possui o tempo e os meios" para levá-la adiante.

Para a filosofia ou para a psicanálise é relativamente fácil chamar de "construção imaginária" esse conjunto de representações que um indivíduo qualquer, entrevistado no meio da rua, chamaria de "eu". No entanto, isso não faz grande sentido para boa parte dos alunos e educadores ao redor do mundo. Ao contrário, a própria concepção de educação do senso comum, nesse contexto, está fortemente vinculada à idéia de que se trata, para qualquer educador, de formar um aluno, e formar, antes de ser dar elementos para que ele, no dizer de uma certa classe média brasileira, "se vire" no mundo, é dar-lhe forma, isto é, dar-lhe (ou dar as condições para que ele a adquira, o que no caso é o mesmo) os atributos com os quais ele tenha uma aparência no mundo, ele seja "alguém" ${ }^{13}$. E dar os atributos "bons", não quaisquer atributos. Alguém de quem se diz que se trata, por exemplo, de um criminoso, é alguém "que não teve formação", ou seja, que não tem forma.

Temos, então, um primeiro problema. Pais querem formar seus filhos, professores querem formar seus alunos, empresas querem formar seus contratados, a sociedade quer formar seus cidadãos. Ter uma forma significa ter, sob a marca abstrata de um "eu" ou de "uma identidade", um conjunto algo extenso de "identidades menores" e poder exibi-las na forma de atributos comunicáveis por meio dos códigos estabelecidos. Essa forma, até Foucault, era obtida por meio da vigilância e da punição, isto é, por meio dos discursos ideológicos. Tratava-se de uma forma rígida e cristalizada. Os indivíduos forjados nestes discursos tornavam-se possuidores de uma "consciência de si" bastante circunscrita e controlada, soi disant racional. Hoje é diferente. Não é mais necessário vigiar nem punir do

\footnotetext{
${ }^{93}$ Evidentemente, não me refiro aqui à idéia de uma formação crítica, tal como concebida, por exemplo, por Paulo Freire.
} 
mesmo modo, a sociedade disciplinar tornou-se agora a sociedade do controle, como afirma Deleuze, e a vigilância que, antes, dedicava-se exclusivamente aos indivíduos, diluiu-se nos espaços. No dizer de Bauman, vivemos uma modernidade líquida na qual também as identidades podem ser descartáveis.

"É nisso que nós, habitantes do líquido mundo moderno, somos diferentes. Buscamos, construímos e mantemos as nossas referências comunais de nossas identidades em movimento - lutando para nos juntarmos aos grupos igualmente móveis e velozes que procuramos, construímos e tentamos manter vivos por um momento, mas não por muito tempo. (...) No admirável mundo novo das oportunidades fugazes e das seguranças frágeis, as identidades ao estilo antigo, rígidas e inegociáveis, simplesmente não funcionam." ${ }^{19}$

Se as identidades variam, hoje, imensamente, nem por isso elas deixam de ser uma busca de segurança e de fixidez, pois essa segurança não se apóia tanto na perenidade quanto na posição em relação ao outro. É sobretudo perante os outros - os fugazes outros do cotidiano, não os outros "fundantes" da construção narcísica, como veremos - que "a identidade" adquire "força". E essa força imaginária alimenta-se dos excessos: o melhor outro é o que é objeto de paixão ou o que é o inimigo.

"Em 1994, um cartaz espalhado pelas ruas de Berlim ridicularizava a lealdade a estruturas que não eram mais capazes de conter as realidades do mundo: "Seu Cristo é judeu. Seu carro é japonês. Sua pizza é italiana. Sua democracia, grega. Seu café, brasileiro. Seu feriado, turco. Seus algarismos, arábicos. Suas letras, latinas. Só o seu vizinho é estrangeiro." ${ }^{15}$

Tudo vale na globalização, todos são "flexíveis", "acabaram-se" as fronteiras, mas "o vizinho" continua sendo "inimigo". Em certa medida, esse tipo de identidade constrói-se quase que exclusivamente por meio do antagonismo. E, quanto a isso, não há que iludirse: estamos falando de ideologia. Olgária Matos não deixa que a questão se ponha à la dérobée:

"A identificação da democracia com liberalismo econômico, a lei como lei de uma classe, o direito como direito de uma classe, a moral como moral de uma classe, resultou na confirmação das forças sociais como absolutamente antagônicas, quer dizer, na oposição entre capital e trabalho, no aniquilamento da idéia de espaço público - aquele que é comum a todos e não apropriação de poucos, - e acessível a todos - e não privativo de alguns, forma de convívio dos conflitos e seu enfrentamento no campo da instituição e exercício de direitos e responsabilidades e que desmanchava a fórmula guerreira da oposição amigo/inimigo." 96

\footnotetext{
${ }^{94}$ Identidade, op. cit., pp. 32-3.

${ }^{95}$ idem, ibidem.

${ }^{96}$ Adivinhas do Tempo, op. cit., p. 71.
} 
Pela mesma via, os produtos disponíveis no mercado global são também "identidades".

No mundo empresarial, onde o marketing substituiu a sociologia - com todas as vantagens e nenhuma desvantagem, segundo se crê no meio -, hoje se "estuda" a identidade das marcas. O processo, conhecido pelo nome de "Branding", consiste em "conhecer a identidade de uma marca através (sic) dos seus atributos". Com isso, as empresas podem definir "sua missão e seus valores" e nisso reside o trabalho com os "intangíveis". A simplicidade quase infantil com que esse trabalho é realizado não chega propriamente a surpreender, já que chegamos a um ponto de codificação tão generalizada "no mercado" que uma frase contendo duas conjunções adversativas é considerada complexa, o que equivale a "uma comunicação não eficiente". O que talvez ainda possa surpreender é o fato de que há agências que chegam a cobrar algo da ordem de um milhão de reais para isso. Coloco a questão, ainda que não possa deter-me sobre ela, porque ela aponta para um aspecto importante da questão.

As chamadas "celebridades" também são consideradas "marcas" pelos profissionais de marketing e como tal são "trabalhadas". Um ator, um escritor, um político, etc. contratam profissionais para cuidar de sua "grife", isto é, antes de tudo, ele mesmo. Desse modo, as marcas devem sempre ter "visibilidade no mercado" e o trabalho de branding visa "construir e gerenciar a marca". O alvo fundamental desse gerenciamento, é claro, são os seus públicos e o objetivo é que esses públicos correspondam "investindo" na marca.

Portanto, de um lado, temos a preocupação com a formação de nossas crianças e dos cidadãos, de outro, o fato de que boa parte da "forma" que se reconhece como tal é uma espécie de co-participação (ou investimento) na marca de uma ou várias celebridades. $\mathrm{O}$ chamado consumidor, de um modo muito mais abrangente que antes, não é um usuário apenas de produtos mas também, e fundamentalmente, de identidades. Ele se conforma a uma marca e a usa, ele veste um Lewis Hamilton, cheira um David Beckham, opina um Arnaldo Jabor.

Como disse Edmundo, no Rei Lear, "a roda completou seu círculo"97, pois o processo de alienação descrito por Marx, no qual um indivíduo não pode reconhecer-se no produto de seu próprio trabalho, parece ter-se tornado algo como seu oposto semelhante: o indivíduo agora somente pode reconhecer-se por meio de um produto, isto é, da marca que sustenta os processos identificatórios. Se em algum momento foi possível falar de um trabalho que se realiza fora do âmbito da vida do indivíduo, agora sequer se vê traço da "vida do indivíduo". O que é um indivíduo sem tênis Nike?

A rigor, a marca é uma identidade sem alteridade: o "Outro"98 ao qual ela se vincula para constituir-se, sobretudo no neoliberalismo, é o mercado, isto é, um pseudooutro que disfarça o mesmo.

\footnotetext{
${ }^{97}$ Ato V, cena III: "The wheel is come full circle".

${ }^{98}$ Logo adiante, explicarei a forma como estou utilizando este "Outro".
} 
A marca obedece a leis de interesse da marca ${ }^{99}$ - portanto, não são leis que possam, em algum momento, adquirir uma dimensão simbólica - e o consumidor parece ser o "pequeno outro" desse jogo. Tudo ocorre como se o consumidor tivesse algum peso na construção ou no gerenciamento da marca, como se as pesquisas de mercado buscassem realmente "identificar as necessidades e os desejos do consumidor" para obter "vantagem competitiva", no entanto, trata-se de uma posição totalmente fictícia, o que as pesquisas buscam é avaliar se a estratégia de marketing está correta, o que o branding busca é assegurar o acionista, e o papel destinado ao consumidor é bastante preciso: ele deve crer. Crer que é o outro da marca, crer que suas posições são ativas e não passivas e, sobretudo, crer que a marca corresponde às suas necessidades.

Não por acaso, a discussão mais up to date do marketing no momento é, quem diria, a singularidade. Não com esse nome e nem na perspectiva aqui tratada, como veremos, porém, a partir do mesmo, por assim dizer, momentum cultural. Tendo operado ao longo das últimas décadas com a idéia "sociológica" de segmentação, segundo a qual os consumidores podem ser classificados em grupos que passam a ser alvos ${ }^{100}$ da marca, o marketeiro acredita hoje que a marca deve dirigir-se "ao indivíduo". Este "dirigir-se" deve ser feito não, obviamente, por meio de produtos singularizados, mas, sim, por meio de "experiências", vinculadas à marca e ao produto, proporcionadas a cada consumidor em particular. Desse modo, se antes os indivíduos acreditavam possuir uma identidade forjada por suas histórias e experiências próprias - as quais, sem que ele suspeitasse, eram condicionadas pela ideologia - hoje, nem sequer as histórias e as experiências necessitam ser próprias. O nascimento do filho de uma hollywood star não é apenas mais significativo que o nascimento de uma criança "qualquer": ele é a matriz dos estereótipos a ser "imitada" - numa imitação perversamente diferente do taclid mencionado acima -, a matriz da experiência vivida e fantasiada pelos pais dessa criança "qualquer". Ser uma celebridade ou uma marca significa possuir um modo de produção de identidades a serem consumidas no mercado. Portanto, se o discurso marketeiro assinala que o graal do momento é o que cada um possui de único - "a essência da marca dirigindo-se à essência de cada um" - e esse graal vem dourado com a idéia de "uma preocupação humanista", na qual as pessoas "não são tratadas como massa mas possuem identidade própria" e isto é "responsabilidade social", de um modo inteiramente previsível, o que temos de fato é uma antisingularidade.

Nesse sentido, reluto em usar termos como "individualismo". O indivíduo que se constituiu como a grande forma da ideologia burguesa possivelmente está extinto. O alferes de Machado de Assis ${ }^{101}$ estava identificado com o status de sua profissão a ponto de não se ver no espelho sem seu uniforme. Hoje, ele não se veria no espelho de modo algum, o que ele veria seria a "profissão" de Brad Pitt, de Ronaldinho ou de Barack Obama.

\footnotetext{
${ }^{99}$ Uma lei que é do interesse do mesmo e não do outro não deveria sequer chamar-se lei.

${ }^{100}$ No Brasil, o termo "público-alvo" era usado "antigamente" - isto é, há uns 15 anos - hoje, claro, o usual é em inglês: target.

${ }^{101}$ No conto "O Espelho".
} 
Se Marx pensou que "nossos produtos poderiam ser espelhos nos quais veríamos refletida nossa natureza essencial" ${ }^{102}$, o teratológico significado que a frase passa a assumir é que, realmente, não havendo natureza essencial alguma e nem nada ou muito pouco que possa ter-se construído independente da ideologia, o que recebe o nome-carcaça de natureza essencial, ou identidade, ou caráter individual, ou o que seja, é aquilo que se mira no espelho dos produtos, dos serviços, das "experiências", em síntese, de vidas inteiras criadas como mercadorias. Nossa "natureza essencial" é que se tornou o espelho do mercado.

Essas considerações partem da idéia, sem saudade, de que já houve construções identitárias, em algum nível, independentes da ideologia. Como o Nada que vai tomando conta de Fantasia na História Sem Fim ${ }^{103}$, a proposta última da ideologia, que é a de ser a realidade vigente, parece ter chegado ao ápice.

Faço um parêntesis antes de prosseguir. Esse "Outro" a que me refiri acima "vem" do Sufismo, não de Lacan, embora, sob certos aspectos, haja semelhança entre um e outro.

"Perdido para aquele que parece não ligar, Sinto dor, ainda que mesmo isso seja bem-vindo do Outro que exige tudo que sou." ${ }^{104}$

Em uma das diferentes travessias que faz Ibn 'Arabî em torno da questão, o Outro é Allâh quando é preciso afirmar a realidade do outro, ou da criatura, ou, nos termos da época, da contingência.

"Entretanto pensadores de pouca inteligência, convencidos de que Allâh faz universalmente o que Ele quer (Cor, 85:16), admitem que o Altíssimo possa agir contrariamente à Sabedoria e àquilo que as coisas são em si mesmas. Alguns dentre eles chegarão até a negar a contingência afirmando a necessidade (absoluta) pelo Ser próprio ou pelo "Outro que a coisa"105. 0 homem de realização verdadeira afirma, quanto a ele, a contingência e conhece sua "dignidade" própria; [ele sabe] o que é o ser contingente, o que o torna contingente enquanto é essencialmente necessário por "Outro (além dele)", e de onde provém este nome de "Outro" que implica para ele esta necessidade. Está aí uma série [de questões] que os Sábios por Allâh são os únicos a conhecer." ${ }^{106}$

Nesse sentido, Allâh é o Outro do homem, o "grande outro", o que está "por trás" de cada

\footnotetext{
${ }^{102}$ Ver citação.

103 De Michael Ende.

104 "Lost to one who seems not care,/ I feel pain, though even that is welcome/ from the Other who demands everything I am". Rumi, Unseen Rain..., p. 23.

${ }^{105}$ Bi-dh-Dhât wa bi-l-ghayr; literalmente: pela Essência ou pelo Outro. A Essência é necessária "por ela mesma" enquanto que qualquer coisa que for vislumbrada como "à parte da Essência" é, consequentemente, necessária por "um Outro além dela mesma" (nota do trad.).

106 Ibn 'Arabî, Chatons, p. 89.
} 
outro com o qual este homem se relaciona e que faz com cada "pequeno outro" esteja conectado com algo maior que ele e, por essa via, com outros "pequenos outros". Em outras palavras, cada outro é um modo de ser do Outro e, portanto, é o Outro.

Ao mesmo tempo, o Outro é também o mundo, isto é, um "outro que Allâh".

"O que é o cosmos, então? É o "outro" (gayr) já que se define como "tudo o que é outro que Deus". Mas não é o outro em todos os sentidos, já que é a totalidade das palavras articuladas no Hálito do Misericordioso, e o Hálito não é completamente diferente Daquele que respira. Ou, em outras palavras, o cosmos é a "revelação" (tajallî) de Deus em seus lugares de manifestação." 107

Assim, o Outro é o que se dá a conhecer - a revelação - de Allâh, é tudo o que é possível conhecer, do mesmo modo em que é "a totalidade das palavras articuladas no Hálito do Misericordioso". O Outro é o Corão, a Lei simbólica. Como Lei, o Outro necessariamente encontra-se numa relação dual com o sujeito ${ }^{108}$. Uma relação, porém, difícil de descreverse no mundo desencantado.

"Sou Eu que recito Meu Livro para ele, por sua língua, enquanto ele Me ouve: e é essa Minha conversa noturna com ele. Esse servidor saboreia Minha palavra. Mas, se ele se detém em seus significados, sai de Mim por sua reflexão e sua meditação. Pois o que lhe cabe é apenas inclinar-se em Minha direção e tornar sua audição perceptiva à Minha Palavra até que Eu esteja presente nesta récita. $\mathrm{E}$ da mesma forma que sou Eu que recito e Eu que o faço ouvir, sou Eu também que Ihe explico Minha Palavra e Ihe interpreto os significados. Esta é a Minha conversa noturna com ele. Ele toma a ciência de Mim e não de sua razão e de sua reflexão e não se preocupa mais em pensar no paraíso, no inferno, na prestação de contas, no Julgamento, nesse baixo mundo ou no mundo futuro pois ele não considera mais essas coisas por meio de seu intelecto, ele não escrutina mais cada versículo com sua reflexão: ele se contenta em abrir os ouvidos ao que Eu Ihe digo. E ele é então testemunha, presente Comigo; e sou Eu que me encarrego de sua instrução." 109

Essa relação dual é uma chave técnica. Ao colocar-se diante de Deus - o infinito, o todopossibilidade, o inabarcável - o "sujeito" estabelece o campo da construção do "alargamento" a que me referi acima. Pela relação com o "Maior" (Allahu Akbar, Deus é o Maior), o homem pode tornar-se maior ${ }^{110}$.

\footnotetext{
${ }^{107}$ Chittick, "La Unidad del Ser", in Postdata, p. 37.

108 "Sujeito", "indivíduo", "pessoa" são todos termos que apresentam problemas de anacronismo. O termo árabe habitualmente utilizado por Ibn 'Arabî é al-insân, "o homem", etmologicamente significando "o esquecido". Ele utiliza também al-rijâl, significando "o homem espiritualmente viril". Lembro, porque não é demais lembrar, um comentário do $\underline{\underline{S}} a \underline{\underline{h}}$ sobre esse termo: "Tudo o que dizemos aqui, nós o dizemos falando de homens espirituais (rijâl) mas pode igualmente tratar-se de mulheres".

${ }^{109}$ Ibn 'Arabî, cit e trad. por Chodkiewicz, in Océan, p. 48.

110 Para fazer notar uma dimensão de crítica ideológica nesta questão, observo que a perspectiva teológica, que é a dos doutores da lei islâmicos, considera que a lembrança constante de que Allah é o Maior deve
} 
Assim, prosseguindo na travessia, o Outro "deixa" de ser Allâh quando aquele que conhece Allâh torna-se Allâh, isto é, quando o homem torna-se o Outro.

"Ibn 'Arabî comentou várias vezes o célebre hadit qudsî em que Deus diz: Meu servidor não cessa de se aproximar de Mim pelas obras excedentes até que Eu o ame. E quando Eu o amo, Eu sou o ouvido pelo qual ele ouve, o olho pelo qual ele vê, a mão com a qual ele pega, o pé com o qual ele anda...

Mas a proximidade mais perfeita (...) não é esta. Na realização das obras excedentes, há ainda a afirmação implícita de uma escolha, de uma vontade própria do servidor. Ora, o servidor puro - al-'abd al-mahd, uma expressão que o Sayh $\underline{\underline{h}}$ alAkbar aplica a si mesmo - é totalmente desprovido de ihtiyâr, de livre arbítrio. É, portanto, no fim do caminho, apenas pela prática dos farâ'id, das obrigações legais (...) que se realizará a plenitude de seu destino espiritual. (...) Então, ele explica, não é mais Deus que se torna o ouvido, o olho, a mão do 'abd: é ele que se torna o ouvido pelo qual Deus ouve, o olho pelo qual Ele vê, a mão com que Ele pega."111

Nesse caso, o Outro é a singularidade, isto é, quando há acoplamento entre o homem e Deus, quando o homem é o Outro.

Nesse caminho, o Outro, visto como "a totalidade das palavras articuladas no Hálito do Misericordioso" e como Lei, é tudo o que está "por trás" das relações entre o sujeito e os outros. Visto como singularidade, é o que está "entre" essas relações, como a terceira margem do rio. E os outros são o motivo dos ciúmes de Allâh. Voltaremos a isso. Fecha parêntesis.

O que procuro pensar aqui é que a ideologia constituiu-se como um véu entre o Outro e o sujeito. Um véu que, inicialmente, permitia o "contato" com o Outro e a construção de um "eu", ainda que imaginário, ao menos com elementos de independência e que, hoje, alargou sua extensão a ponto de fazer com que muitos acreditem que a peneira é o próprio sol. Claro está que, quando uso o termo "ideologia", por uma questão de foco, seu significado é o mais amplo possível. Na realidade, como a ideologia não é simplesmente um bloco homogêneo, seriam necessárias várias distinções dentro do termo que, no contexto, não vêm ao caso.

Assim, a partir do Sufismo, pretendo estabelecer uma radical distinção entre identidade e singularidade. De um lado, estou elaborando uma montagem na qual podemos ver a iden-

\footnotetext{
servir a que os homens percebam sua pequenez e busquem, portanto, a humildade. 0 diálogo místico entre Deus e o homem seria, nesse caso, uma blasfêmia. Com o Desencantamento, ele deixa de ser uma blasfêmia e passa a ser uma fantasia ingênua quando não um delírio. Esta grande vitória teológica do Mundo Desencantado faz perder de vista a dimensão técnica da questão: o homem é tanto "pequeno" quanto "grande". Tudo, como sempre, depende de tempo, lugar e pessoas, isto é, da situação concreta. Pretender que o homem - ou qualquer coisa - seja isto ou aquilo, independente das situações, corresponde ao mau hábito mental da abstração sem limites, já tão criticado pela filosofia contemporânea.

${ }^{111}$ Chodkiewicz, Le Sceau, p. 136-37.
} 
tidade como processo e como resultado. De outro, pretendo pensar a singularidade como um outro tipo de montagem, como veremos adiante.

Vista como um processo de formação do sujeito, a identidade estaria ligada ao narcisismo, compreendido aqui como uma estrutura fundante. No entanto, como vimos, há uma outra estrutura, a ideológica - e aqui me interessa ver a ideologia como uma estrutura que, como se fosse uma estrutura fundante, orienta a construção e a consciência de si dos sujeitos. Este como se da ideologia é, na verdade, um mecanismo próprio do imaginário, presente, portanto, em todos os processos de construção imaginária do sujeito.

Se, na estrutura narcísica, o sujeito constrói-se como se fosse outros, isto é, apropriandose das palavras, das coisas e dos modelos-de-gente dispostos ao seu redor, ou numa palavra, dialogando com o Outro, na estrutura ideológica, há como que um tecido que se interpõe entre o Outro e o sujeito de modo que esse diálogo passe a ser sancionado, ou não, pela ideologia. Esse diálogo torna-se, portanto, restrito e codificado segundo certas normas ou parâmetros que não são as que a cultura, como um todo, pode ou poderia produzir, mas, sim, as que são determinadas por um conjunto determinado de interesses $^{112}$.

Avancemos ainda na questão da identidade. Derrida vê a singularidade de um modo que, por um lado, o distancia e, por outro, aproxima-o da Mística, razão pela qual o seu pensamento acolhe-se naturalmente nesse contexto. Para o educador pouco familiarizado com a sua obra, faço uma breve introdução.

A História da Filosofia está marcada, como assinala Derrida, por "dualidades hierarquizantes". Seja o par "alma e corpo", por exemplo, em Platão, sejam as dicotomias "Deus e o mundo", "essência e existência", "cultura e natureza", "homem e mulher", enfim, trata-se repetidamente de estabelecer antagonismos nos quais um dos termos deve prevalecer sobre o outro. Assim, a alma é, num certo período, dita superior ao corpo, assim como Deus ao mundo, a essência à existência, a cultura à natureza e o homem à mulher. Em seguida, há historicamente uma inversão ineluctável e o corpo passa a ser considerado, como por exemplo, a partir de Nietzche até os anos 60, o lugar da experiência concreta e do "saber verdadeiro" em oposição a uma alma abstrata, idealizada e ideológica. Do mesmo modo, o mundo e a existência passam a preceder Deus e a essência, a natureza passa a oferecer mais certezas que a cultura e há quem professe, ainda que em meios

\footnotetext{
112 Esclareço, a fim de evitar ruídos na escuta dessa construção, que já não se vê esse "conjunto determinado de interesses" como os interesses das classes hegemônicas. As divisões claras e os jogos de poder identificáveis nos sécs. XIX e XX não parecem ser hoje possíveis. Quer pensemos, com Bauman, em liquefação, ou, com Guénon (cf Le regne de la quantité et les signes des temps, op. cit.), em volatilização, a matéria real parece, neste novo tempo, ter-se mesclado a ponto de não podermos mais produzir distinções a partir de "segmentos", classes ou de certas categorias. Há diversos níveis de "interesses" que sustentam os véus da ideologia, sobretudo aqueles que envolvem a negação dos conflitos na cena pública e sua substituição pelo antagonismo. Não obstante, as classes hegemônicas continuam aí. O fato de que os interesses estejam mesclados não significa que o poder esteja partilhado. Este continua, como sempre, nas mãos dos de sempre. $\mathrm{E}$ isto também não pode ser deixado à la dérobée.
} 
menos doutos, que a mulher é superior ao homem. (Claro está que, dita com tamanha simplicidade, a observação derridiana parece reduzir toda a história da filosofia ocidental a uma sucessão de estreitezas. Não se trata disso, a simplificação obedece ao escopo de uma "breve introdução", a serviço da discussão que pretendo iniciar).

Com Derrida, vislumbramos consequências fundamentais da desconstrução das dualidades hierarquizantes. Como movimento próprio da cultura, a desconstrução ao mesmo tempo inverte e desloca as dicotomias. Não se trata de simplesmente inverter as polaridades: dizer que a mulher é superior ao homem, por exemplo, é recolocar a hierarquia e manter a estrutura comodamente intacta. Dar ênfase à desconstrução é permanentemente escapar do aprisionamento da hierarquia, da escolha de "um outro" que "sirva" como inferior para garantir a supremacia da "nossa construção". Ocidente versus oriente, capitalismo versus comunismo, "nacional" versus "estrangeiro", identidade versus alteridade. A todo momento, a dualidade hierarquizante se recoloca, como um processo da repetida e insistente escolha pela estabilidade da identidade - "o brasileiro ", "o filósofo", "o homossexual", "o negro", "a mulher" - e dos lugares de identificação - as "tribos", o "meu" grupo, o "feminismo", a "negritude". Para assegurar essa identidade, há que eleger o que Ihe é imaginariamente contra e situá-lo "abaixo", no âmbito reservado aos dominados.

Evidentemente, não se trata aqui de reduzir as lutas políticas - que, não sempre mas muitas vezes, assumem o formato circunstancial de "oposições" - a uma construção imaginária exclusivamente a serviço de um processo "metafísico" identificatório. O feminismo, para ficar num exemplo sumamente didático, que luta para estabelecer leis de equiparação salarial ou que leva à cena pública as reflexões sobre o lugar da mulher perante a cultura e o tempo simbólico em que vivemos ou que propõe a crítica à violência contra a mulher, violência esta "justificada" por estar a mulher posta como alteridade a ser dominada, tudo isso é diferente, bastante diferente, do feminismo como identidade abstrata e cerceadora que impele e condiciona as mulheres a agir "femininamente", que prega "uma natureza feminina", "qualidades do feminino", "delicadeza, sensibilidade e passividade" como "próprias da mulher" e, sobretudo, que distingue "o ser da mulher" do "ser do homem" a fim de que, pela diferença irredutível, ambos sejam vistos como "complementares" e "necessários um ao outro", como, na paupérrima imagem do senso comum, duas metades de uma agrotóxica laranja, com o que se garante que os homens e as mulheres comportem-se previsivelmente, que os laços sociais e afetivos entre homens e mulheres sejam previsíveis, que o outro seja sempre um complemento, nunca uma realidade independente, inapreensível, incontrolável, instável, não idêntica a si mesma, numa palavra, misteriosa.

Anos atrás, quando, no último período da faculdade, atendi sob supervisão de um professor uma paciente negra, ouvi, estarrecida, seu relato de que decidira mudar-se com o marido para a Alemanha porque havia desistido de morar no Brasil, "um país tão racista". Seu argumento imediato, no calor do discurso indignado, era que a "prova" desse racismo evidenciava-se no fato de que, sistematicamente, ao entrar num restaurante com o 
marido, branco, as pessoas a olhavam "espantadas de ver uma mulher negra com um homem branco". Ela era uma mulher linda, mas não the ocorria que as pessoas pudessem olhar para ela, por exemplo, por sua beleza. Aprisionada na armadilha da indignação cristalizada contra o preconceito, na dualidade hierarquizante "negritude X preconceito", ela se ocultava de sua beleza, segregando-a e excluindo-a. Para ela, a identidade totalmente abstrata - abstrata porque era independente de qualquer situação concreta, como uma simples aparição na entrada de um restaurante - que lhe impunha a "realidade inexorável" de "ser negra", primava sobre qualquer contato atual com os outros. Era um preconceito, como, indistintamente, toda identidade cristalizada o é. Além do fato absolutamente corriqueiro de que as pessoas olham na direção de qualquer um que entre num restaurante, poderíamos imaginar uma entrevista com algumas dessas pessoas. A enquete poderia ser mais ou menos assim: "você acaba de olhar na direção da porta de entrada do restaurante, por que?" Quantas vezes deveríamos esperar pela resposta: "olhei porque vi uma negra junto com um branco e achei estranho"?

A questão aqui, obviamente, não é negar o preconceito, existente e facilmente constatável no Brasil, mas, sim, questionar a "identidade negra" naquilo que ela possui de véu sobre a realidade singular. Do mesmo modo, se uma mulher age levianamente com seus colegas de trabalho, tomando atitudes que demonstram pouco caráter e isso acarreta uma reação qualquer da parte deles contra ela, seria claramente um equívoco, para dizer o mínimo, se ela dissesse que eles estão sendo "preconceituosos com ela por ser mulher". Isso é óbvio, mas quantos de nós já não viram isso acontecer?

A identidade feminina, masculina, a identidade brasileira, a americana, a ocidental, sendo construções abstratas, apresentam esse enorme inconveniente de velar o lugar singular no qual está posta toda situação atual, concreta. Mais adiante, será preciso lembrar a velha discussão sobre o quanto é possível estar em contato com uma "situação atual e concreta", mas, por ora, ainda necessito trabalhar mais alguns problemas da identidade. Sigo ainda um trilhamento alargado por Derrida.

Em que medida os movimentos, por exemplo, do "Orgulho Negro" e do "Orgulho Gay" podem realizar ações políticas e, ao mesmo tempo, ações que vão contra a política? Se a cultura tende a constituir massas de representações imaginárias, pastiches mais ou menos homogêneos de formas humanas como "o negro", "o oriental", "o homossexual" sem poder tomar contato com a condição política do homem negro ou homossexual, etc. no país tal, na época tal, sob a ideologia tal, torna-se uma ação política enriquecer o espaço público com os relatos da vida do negro ou do homossexual, etc. No entanto, se um homem, antes de ser singular, portanto, indefinível e ao mesmo tempo único, exige-se ser visto "sem preconceito" - o que é um atributo negativo - e isso quer dizer ser visto positivamente como um negro, um homossexual, um brasileiro, um terceiromundista, ou seja, qualquer característica genérica, essa pode ser uma perspectiva ilusória. Lutar contra um preconceito não pode ser identificar-se com um grupo porque um dos mecanismos de construção e de manutenção do preconceito reside justamente nessa identificação. 
Em uma certa perspectiva, o ego é reativo e vive de antagonismos. A identidade, sendo circunscrita por "aquilo que não é idêntico", alimenta-se do seu oposto. Mediante à frase: "Adoro São Paulo", a indefectível "resposta": "É, mas, o Rio também é legal" traz à tona uma espécie de hábito mental do antagonismo. Poder-se-ia dizer: "Eu adoro o Rio também", no entanto, o "é, mas" inicia compulsoriamente a frase como que indicando que a simples afirmação relativa a uma cidade implica, sutilmente, uma negação da outra. Certos cientistas cognitivistas chamam esse metamodelo linguístico de "equivalência complexa" e terei a oportunidade de falar mais sobre isso em outros capítulos. No caso, não se pode afirmar que há uma identificação pura e simples dos sujeitos perante sua cidade natal mas, antes, haveria uma identificação com o hábito de antagonizar, como se fosse um condicionamento no sentido mais pavloviano do termo ou, para usar uma expressão mais atual, um modelo mental.

Diante do preconceito "rio de janeiro versus são paulo", nascido sob as condições históricas próprias do desenvolvimento dessas cidades, vivemos sob um fort-da ininterrupto ${ }^{113}$, num jogo de toma lá dá cá, no qual se trata de, a cada vez, ocupar uma posição e defendêla com os recursos disponíveis. Essa é a identidade prêt-à-porter, uma forma ainda mais radical da identidade descartável de que falava Bauman. Nada é mais estúpido ou irracional que as afirmações genéricas sobre o "carioca" ou o "paulista", no entanto, este pode ser o procedimento numa conversa de horas a fio, em que pessoas buscarão, na memória de suas "experiências vividas", as provas cabais de suas considerações. Nesse caso, a posição adotada vai gradativamente sendo libidinizada, a ponto de poder tornarse, na madrugada, um sério litígio. Em alguns casos, pode acabar em morte. E o assunto pode ser também Proust versus Thomas Mann ou Lacan versus Derrida, caso se suponha que tais considerações, por qualquer razão, excluiriam os círculos doutos.

Não pretendo analisar essas situações de litígio, portanto, não se trata de pensar nos processos identificatórios como causa (ou como origem) do desentendimento frente "ao outro". O que me interessa aqui é estabelecer algumas conexões entre os processos identificatórios e o antagonismo como modelo mental.

A Mística chamou a um aspecto desses processos de "paixão" (na realidade, há muitos termos no Sufismo que poderiam ser traduzidos por paixão e muitas sutilezas em jogo que aqui não vêm ao caso ${ }^{114}$ ). Tecnicamente, a paixão descreve esse adormecimento ou entorpecimento do sujeito que faz com que ele permaneça aprisionado "num cárcere cuja porta está destrancada", identificado com uma posição hiperinflada pelo antagonismo.

Para o chamado senso comum, é difícil admitir que "a porta esteja destrancada", isto é, que bastaria "desidentificar-se" para sair desse trilhamento e buscar outro. Ao contrário, nossa experiência é a de que a porta está trancada, daí a necessidade de se fazer, por ex-

\footnotetext{
${ }^{113}$ Referência a Freud. Cf. Além do Princípio do Prazer, 1920.

114 O termo tem longo percurso na história da filosofia, no entanto, peço ao leitor que esqueça esse percurso, pois aqui se trata de uma tradução aproximada, na qual busco alguma ressonância com o nosso hábito mental atual.
} 
emplo, em Psicanálise, um trajeto simbólico na transferência com o analista.

De um modo geral, nossa ciência e nossa vivência do ego nos diz que não seria exatamente factível ser totalmente outro a qualquer momento. A crença de que "eu sou assim" não é simplesmente uma crença (no sentido atual do termo), é um aspecto central da estrutura fundante que é o narcisismo, tal como descrito em Freud e em Lacan. No entanto, essa estrutura trabalha com construções, isto é, o narcisismo poderia igualmente servir a várias construções - e desconstruções - ou a vários processos identificatórios e a várias desidentificações. Ou seja, como urdidura, o narcisismo viabiliza inúmeras tramas. A construção de "uma" identidade, isto é, de um sistema, digamos, entreaberto, que permite muito seletivamente, ao longo do tempo, a entrada de alguns novos elementos e de elaboração de alguns jogos entre eles, enfim, a rigidez, o condicionamento, a cristalização e o estreitamento a que muitas vezes chamamos "identidade" não é resultante da estrutura narcísica mas sim do uso que dela fazem a cultura e a ideologia, numa certa época, num determinado momentum.

Um Shay $\underline{\underline{h}}^{115}$ na Turquia me disse certa vez: "as pessoas no ocidente são engraçadas, elas dizem 'eu sinto muito mas eu sou assim', quando, na verdade, elas nem sentem muito e nem são assim."

Novamente, não se trata de melancolia ou de saudade da origem: ao citar um Shay $\underline{\underline{h}}$ na Turquia, não faço dele "um representante" do oriente, nem quero dizer que o oriente é melhor porque ali há maior plasticidade da estrutura narcísica (não há mais), nem quero dizer que "nos desviamos".

Interessa-me pensar que uma Cultura pode trabalhar no sentido de gerar, em alguma medida, essa plasticidade e essa variabilidade e que isso tem a ver com Educação.

${ }^{115}$ Lit., "velho", utilizada entre os sufis com o sentido de "mestre". 


\subsection{DUALIDADE COMO ESTRUTURA SIMBÓLICA NO MUNDO ENCANTADO}

A astúcia é movimento. Um homem ladino estabelecido em algum lugar se converte num homem falso. (Alim al Ladino) ${ }^{116}$

Em uma certa perspectiva sufi, os processos imaginários (narcísicos, ideológicos, etc.) de identificação do sujeito - com ele mesmo, com os outros, com as coisas - são, num plano, por assim dizer, grosseiro de formação do ego, bastante estreitadores das possibilidades dos sujeitos. Há planos mais sutis que podem ser alcançados. Além disso, há um estreitamento, como vimos, ainda maior na sociedade neoliberal, na qual um estado regulador - como o Outro regula - é impensável e na qual vigora o jogo das identidades sem alteridade, isto é, das marcas no mercado.

O que os sufis poderiam chamar de um nível pouco elaborado ou grosseiro da construção egóica pode ser descrito, entre outros, como um lugar em que o hábito de antagonizar cumpre um papel preponderante. Visto como comportamento, esse hábito aparece em qualquer situação, desde as mais simples equivalências complexas até o modo retórico de pensar sobre uma questão iniciando por pensar o que ela não seria. Visto como estrutura, ele nos remete a aspectos importantes do lugar da identidade e da alteridade no nosso contexto.

É na perspectiva mística que a dualidade é uma estrutura operativa, isto é, não se trata apenas de uma estrutura, como diríamos hoje, "inconsciente", da qual a fala ou a ação do sujeito é "efeito". Ao contrário, porque o místico é um malabarista do simbólico, trata-se, para ele, de fazer ciência e de operar com as possibilidades simbólicas ${ }^{117}$. Uma longa

\footnotetext{
${ }^{116}$ Famoso personagem oriental. Ver Idries Shah, Una Gacela Velada, op. cit., p. 84.

${ }^{117}$ Novamente, tratei com mais detalhe desta questão em meu livro: "Sentidos do Caleidoscópio...".
} 
travessia deve ser feita por nós, gente do mundo desencantado, até esse universo do Sufismo que nos é tão estranhamente familiar, no sentido do unheimlich freudiano. Especificamente, atravessar a questão da dualidade é como obter uma espécie de panorâmica da ciência simbólica e, no caso, faremos este longo percurso com o objetivo de alcançar a urdidura do singular.

Operada pela Mística e, especificamente, pelo Sufismo, uma "ciência dos números" considera que a dualidade é uma estrutura simbólica e, como tal, constitui um universo de possibilidades que a distingue, por exemplo, do ternário, do quaternário, etc.

Assim, falar em Deus e o homem, ou em Deus e o mundo, é muito diferente de falar em Deus, homem e mundo, ou em Deus, homem, outro; do mesmo modo, a dualidade almacorpo abre um campo diverso do ternário espírito-alma-corpo; ou sujeito-outro difere de sujeito-linguagem-outro. Em outras palavras, o fato da relação ser "a três" já implica uma "qualidade" que a diferencia da relação "a dois" ou de qualquer outra, independentemente do "conteúdo" dessas relações.

Entre as características fundamentais da dualidade, residem, no plano sensível, a diferença sexual anatômica que define o par "masculino e feminino" e, no plano intelectual, o poder de síntese: utilizando apenas dois termos, é possível falar de universos inteiros como céu e terra, vida e morte, yin e yang, etc.

Note-se, a fim de evitar equívocos, que a diferença sexual anatômica não é um fato em si, que determina a importância da dualidade. Antes deveríamos propor o contrário, é a estrutura dual que fornece o recorte importante da sexualidade como "dois", sendo que encontraremos recortes como "três", "quatro" ou mesmo "cinco"118. Entre os muitos exemplos de "desapego" dessa diferença estritamente anatômica, podemos evocar a narrativa de Richard Sennett ${ }^{119}$, em que vemos os orgulhosos atenienses do séc $V$ a.C., viris cidadãos, enamorados tanto de sua cidade quanto de belos jovens, cujo "calor corporal" os distinguia das mulheres e dos escravos, pois estes últimos, ainda que anatômicamente "homens", tornavam-se, como as mulheres, "frios", devido à escravidão.

Prosseguindo, podemos dizer, por exemplo, que céu e terra, vida e morte, yin e yang constituem antagonismos. No entanto, na tradição mística, não são antagonismos fixos e, por definição, estão muito longe de constituir "dualidades hierarquizantes". No caso do par cosmológico "yin e yang", a sua mobilidade é em parte conhecida até mesmo pelo senso comum atual, acostumado a ver o já midiático desenho que mostra a alternância entre os opostos: $\$$. Desse modo, não é difícil para um apreciador de comida natural ou de receitas exóticas compreender que um mesmo alimento pode ser yin em relação a outro e yang em relação a um terceiro. $E$, como se trata da busca de um equilíbrio - e, é impor-

\footnotetext{
${ }^{118}$ Notadamente, uma simbologia mística pensa o amor sexual na perspectiva da unio mystica e, desse modo, o que se focaliza é o ternário "homem-mulher-Deus". Já alguns setores da medicina contemporânea, longe de qualquer preocupação "simbólica", distinguem cinco gêneros.

${ }^{119}$ Carne e Pedra, op. cit., p. 39..
} 
tante lembrar porque muitos autores "ocidentais" se esquecem disso, trata-se de um equilíbrio dinâmico -, nenhum dos termos é "mais necessário que" ou "independente do" outro.

Para explicar esta interdependência, é preciso considerar que há uma diferença entre as 3 primeiras estruturas - a unidade, a dualidade e o ternário - e as demais (o quaternário, etc.). O ternário é visto, sob muitos aspectos, como um retorno à unidade e, desse modo, o caminho do um ao três é circular: o dois é a diferenciação/distinção e o três é a volta ao um diferenciadamente. Assim, a expressão "caminho do meio", que abre a Divina Comédia ( $N e l$ mezzo del camin di nostra vita), utilizada em tantas ordens místicas, referese ao ternário que "superou" a dualidade das duas margens do caminho e retornou à unidade.

A superação em jogo não é de ordem lógica nem mental ${ }^{120}$. Os processos de identificação, como sabemos, incluem constitutivamente um "oposto". Assim, se um sujeito está identificado com uma determinada posição egóica, operar uma desidentificação é, ao mesmo tempo e simultaneamente, poder deslocar-se para qualquer outra posição e incluir aquela que lhe é inteiramente antagônica.

Há inúmeras histórias que transmitem estruturalmente este lugar. Eis algumas delas.

"Um discípulo foi estudar com um mestre. Certo dia, ele viu seu mestre soprando suas mãos e perguntou-Ihe por que ele o fazia. O mestre lhe respondeu que visava esquentá-las. Algum tempo depois, o discípulo viu seu mestre soprando a sopa que Ihe havia sido servida no jantar. Perguntando-lhe o motivo de seu gesto, ficou surpreso ao ouvir de seu mestre que sua intenção era esfriá-la. Sem demora, abandonou o estudo, certo de tratar-se de um mestre inconfiável."

"O diabo foi ter com a velha: - muitos dizem que você é poderosa - disse-lhe com desdém - mas eu tenho certeza de que sou muito mais poderoso. A velha sequer pareceu ouvi-lo. Ele continuou: - vamos fazer uma aposta para decidir de uma vez por todas quem é mais poderoso. Ela se animou, pois gostava de apostas. 0 diabo propos: - cada um de nós vai e faz uma maldade com alguém e então poderemos comparar. A velha concordou.

O diabo foi ao mercado e começou a fazer uma intriga com o dono de um bazar acerca de um cliente. Em seguida, fez uma intriga com o cliente acerca do dono do bazar. Ambos brigaram, um deles foi morto e o outro foi preso. Satisfeito, o diabo cedeu a vez à sua oponente.

A velha foi a uma loja de tecidos e dirigiu-se ao vendedor: - Bondoso senhor, venho aqui pedir-lhe para que me ajude a escolher um tecido fino, porém, sintome muito envergonhada pois se trata de um presente que meu filho quer dar à

\footnotetext{
${ }^{120}$ Não é preciso dizer que as interpretações da Divina Comédia que focalizam este "meio" e essa "superação" na perspectiva de um equilíbrio estático e, por essa via, como, por exemplo, uma condenação moral dos excessos, pertencem a este lugar grosseiro do ego e dos antagonismos fixos.
} 
sua amante. Eu, pessoalmente, não estou de acordo com esse relacionamento ilícito, porém, não posso opor-me a meu filho.

O vendedor apiedou-se da velha e ajudou-a a escolher o corte. Depois de agradecer e despedir-se, a velha dirigiu-se rapidamente à casa do próprio vendedor, sabendo que ali encontraria sua esposa sozinha: - Bondosa senhora, já está na hora da oração e estou longe ainda de minha casa, será que eu poderia juntar-me à senhora para cumprir minhas obrigações perante Allâh? A esposa do vendedor aquiesceu prontamente e, quando estavam em meio à reza, a velha, discretamente, deixou o pacote com o tecido num canto da casa.

Ao chegar em casa à noite, o vendedor deparou com o pacote e imediatamente concluiu que sua esposa o havia recebido de seu amante, o filho da velha. Indignado, o homem expulsou sua mulher de casa.

O diabo foi tomar satisfação com a velha: - O que é isso? Como você quer provar que é mais poderosa que eu fazendo uma bobagem dessas. Eu consegui a morte de um e a prisão de outro, ou seja, com um movimento, desgracei duas vidas. Você consegue apenas uma briga de marido e mulher. A velha respondeu: Ainda não terminei.

No dia seguinte, ela voltou à loja de tecidos e explicou ao vendedor que, distraída que era, havia esquecido o presente na casa de uma generosa mulher que a havia acolhido para a oração do meio-dia. O vendedor percebeu seu terrível engano, correu atrás de sua mulher e, chorando, pediu-lhe desculpas. A esposa, vendo a sinceridade do marido, desculpou-o e eles se reconcilharam.

O diabo ficou fulo: - Como se não bastasse, você ainda os ajudou! A velha, fitando-o, disse: - Eu sou mais poderosa. Você foi capaz de fazer o mal. Eu fui capaz de fazer. E de desfazer."

Meu objetivo não é propriamente descrever exatamente o que seria uma desidentificação para um sufi mas, apenas, extrair do tema as operações que parecem ser factíveis no contexto em que estou trabalhando.

Assim, uma operação de desidentificação inclui desde ser capaz de deixar de comer chocolates ou de fumar até tornar-se alguém que, na terminologia técnica do Sufismo, pode ser chamado de santo (wali) ou conhecedor ('arif), isto é, que não tem forma, nem identidade, e que pode, portanto, ocupar posições singulares.

Duas distinções são aqui oportunas: 1) O pensamento de Derrida parece conceber a "morte" da identidade e a ênfase na singularidade de um modo muito semelhante a este. No entanto, lembro, mais uma vez, que a via mística, à diferença da filosofia, não é uma via de pensamento exclusivamente. 2) Deixar de fumar por meio da chamada força de vontade não é o mesmo que desidentificação. A força de vontade é uma operação mental, uma auto-imposição de tolerância à frustração. Qualquer disciplina mental ou física pode ensinar a tolerância - relativa - à frustração, como, por exemplo, um treinamento militar. Nada está mais distante disso que a desidentificação, que é uma operação de ordem simbólica e muito diferente da violência de uma disciplina que opera por meio da força ou do 
autoconvencimento. Teremos oportunidade de voltar a essa questão, o fundamental, por enquanto, é compreender que a relação unidade-dualidade-ternário refere-se estruturalmente à uma operação - e não apenas a uma idéia - de desidentificação.

Um modo bastante preciso de pensar a dualidade no contexto sufi é saber que ela se constitui como a síntese da relação entre o círculo e o ponto: o diâmetro - que forja a dualidade - é a própria definição do tamanho da circunferência.

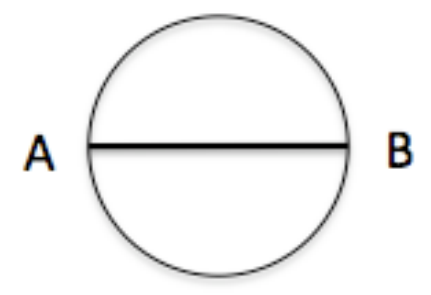

Assim, se dizemos que A e B formam uma dualidade, quer dizer que o par encerra, como possibilidade, todas as posições contidas na circunferência e, pensando tridimensionalmente, na esfera.

A idéia de circularidade cumpre um papel importante no contexto. O tempo circular, por exemplo, possui possibilidades que o linear não possui e vice-versa. Portanto, do ponto de vista técnico do Sufismo, não se trata de "crer" que o tempo é circular ou de teorizar que o tempo "na realidade" é circular. Não teremos dificuldade em encontrar um mesmo autor sufi que mencione, em passagens, um tempo linear, em outros momentos, um tempo circular, em outros ainda, um tempo não contínuo, etc.

Tomemos um exemplo de tratamento operativo da dualidade. O par nafs e qalb. Como vimos, o termo árabe nafs pode ser traduzido por alma e, mais modernamente, por ego. 0 termo qalb traduz-se literalmente por coração e pode ser assimilado ao lugar da singularidade (fardanyyia). Coração e alma ou coração e ego formam uma dualidade entre as mais recorrentes no Sufismo.

As observações que se seguem são cruciais para nosso tema.

Em primeiro lugar, não seria correto dizer, na esteira de um orientalismo acadêmico e mecanicista, que "os sufis acreditam que o ser humano está divido em alma e coração". Tampouco seria adequado supor que há uma teoria sufi a respeito do psiquismo humano. Encontraremos nos autores sufis, como, de resto, em autores místicos de um modo geral, às vezes num mesmo texto, uma "descrição" da alma possuindo 7 níveis e outra possuindo, digamos, 12. Às vezes, são 3 tipos e 4 subtipos, e assim por diante. 0 coração pode apresentar 2, 3 ou 5 faces, pode ter posições; Ibn 'Arabî, entre outros, fala, por exemplo, da inversão do coração. Finalmente, a alma aparece, em passagens, como "o inimigo" do coração, em outras, como o seu complementar, em outras ainda como o seu sinônimo. 
Isso é assim porque esta dualidade também é vista como um processo. A alma, inicialmente, designa a matéria bruta sobre a qual o homem deve trabalhar-se. A ignorância e os condicionamentos ${ }^{121}$ tornam a alma reativa: em vez de entrar em contato com as possibilidades de cada situação, ela reage abstratamente com base em seus preconceitos e em sua incapacidade de perceber essas possibilidades. Num estágio, como eu disse, considerado grosseiro, sua reatividade consiste basicamente em buscar uma identificação quase que totalmente mental - sem corpo, sem acoplamento, sem articulação, sem harmônico - com algum aspecto que lhe pareça, de algum modo, assegurador, alguma certeza, ainda que totalmente improvável. O antagonismo, nesse caso, é a reatividade mais simples e "o outro" serve de modo irrecusável a esse propósito. Apaixonar-se, idolatrar, admirar ou julgar, acusar, culpar "o outro" quando se trata de alimentar ilusões narcísicas ou de qualquer outro autofavorecimento é deixar-se levar pela mais primitiva das "tentações". Esta alma, nesse "estágio", é preconceituosa em relação a qualquer coisa. 0 Corão se refere a ela como "a alma instigadora do mal" e é nesse sentido que ela se opõe - tecnicamente, não moralmente - ao coração. De modo reativo, ela inveja o coração. A sura $^{122}$ al-Falaq, "A Aurora", que é uma das 3 suras consideradas "de proteção" no Islam, contém o seguinte verso: "[eu me refugio no Senhor da aurora] ... contra o mal de um invejoso quando ele inveja"123. Comentando-o, al-Qâchânî, um discípulo de Ibn 'Arabî, explica-nos:

"... isto é, contra o mal da alma (al-nafs) quando ela tem inveja da iluminação do coração e usurpa as atribuições e os conhecimentos deste coração pela escuta às escondidas, para oprimi-lo em seguida, deprimi-lo e envolvê-lo (...)."124

É a esta alma que se refere Ibn 'Arabî ao comentar um outro verso "Ó aqueles que crêem, combatam entre os infiéis os que Ihe são próximos" (Corão, 9:123):

O fardo do sufi, neste verso, consiste em considerar que ele visa sua própria alma individual (...) pois, de todos os infiéis, ela é o mais próximo dele. ${ }^{125}$

O trabalho de autoconhecimento visa, portanto, ensinar a alma a colocar-se nas situações com mais recursos, de modo mais harmônico e perceptivo, de modo a poder relacionar-se com o outro - qualquer outro: a terra, as artes, os grupos, as idéias, a noite, os joelhos em modo atual, ou, pelo menos, o mais próximo do atual possível - sem negar, é claro, porque não se trata de excluir, as construções, os termos de referência, as estruturas simbólicas, enfim, tudo o que dá sustentação simbólica ao atual.

\footnotetext{
${ }^{121}$ Ver nota 85.

122 Capítulo do Corão.

123 Trata-se da sura 113, que diz integralmente: "Em nome de Deus, o Misericordioso, o Misericordiador / Dize: eu me refugio no Senhor da aurora / Contra o mal do que Ele criou / E contra o mal do obscurescimento quando ele invade / E contra o mal das sopradoras nos nós / E contra o mal de um invejoso quando ele inveja".

${ }^{124}$ Abdu-R-Razzâq al-Qâchânî, trad. por M. Valsân, Le commentaire ésotérique des trois sourates finales, in Études Traditionnelles, jul-aout-1969, p.166.

${ }^{125}$ Cit. e trad por Chodkiewicz, in Océan, op. cit., p. 133.
} 
Num "estágio" intermediário do trabalho sobre a alma, a disciplina de auto-observação já produziu seus efeitos e o ego agora é menos "dominador". O Corão refere-se a esta alma como "acusadora". Ibn 'Arabî explica que esta auto-acusação - novamente, técnica, não moral - encerra um dos segredos do Caminho.

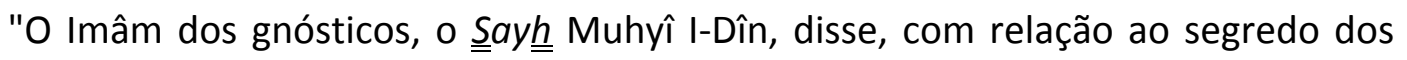
números: "Quando o homem combate sua própria paixão, que dê proeminência ao número par sobre o ímpar"- isto é: que privilegie a contemplação simultânea do Senhor e do servidor sobre o "ímpar", que é a contemplação exclusiva do Senhor - "e quando ele combate a paixão dos outros, que a autoridade do ímpar se sobreponha à do par" - isto é: que ele privilegie a contemplação do Senhor somente, atestando assim a Unicidade divina." ${ }^{126}$

Uma nota ${ }^{127}$ de Chodkiewicz colocada no final da frase esclarece a perspectiva em questão:

"A extinção na Unicidade divina anula a Lei que, sendo uma relação, implica necessariamente na dualidade. Para o aspirante, ver Deus como Agente dos atos dos outros [portanto, como "um", ímpar] é ao mesmo tempo uma condição necessária da realização espiritual e o fundamento doutrinal de uma ética das mais exigentes; ver Deus como único agente de seus próprios atos - ainda que se trate aqui e lá de uma mesma evidência metafísica - corre o risco, ao contrário, de conduzir ao antinomismo." 128

O outro, nesse caso, torna-se um lugar de "purificação" da alma. Além de não poder "projetar" suas fraquezas no outro, o sujeito ainda deve ser capaz de vê-lo como "um modelo excelente". Esta operação, não sendo mental, não sendo produto de uma "boa vontade", não sendo um exercício de autorrestrição a mascarar a busca de uma recompensa, é fruto de um trabalho com materiais específicos. Neste sentido, esta alma ou ego é vista como complementar ao coração, ela é o lugar em que se exige a "virilidade espiritual" e a "paciência ativa". Ver no outro um modelo excelente é ver seu coração. Concordar verbo que denuncia sua origem ligada a cor, cordis, coração -, estar de acordo, buscar acordos e entendimento mútuo é uma prática de denarcisação ${ }^{129}$ que, no setting adequado, opera uma sutilização do ego e possibilita a construção de lugares mais sofisticados que o antagonismo.

Bem entendido que concordar, buscar acordos e entendimentos mútuos dentro de uma visão pragmática, que visa garantir resultados comerciais ou dentro de uma visão moral, que visa garantir a ordem e escamotear conflitos, são coisas totalmente diferentes do que

\footnotetext{
${ }^{126}$ Abd el-Kader, Écrits, p. 148.

${ }^{127}$ Chodkiewicz, in Écrits, p. 215, n. 167.

${ }^{128}$ Citado in Sentidos do Caleidoscópio, op. cit., p. 175-6.

${ }^{129}$ Tomo agora uma idéia psicanalítica, a de denarcização, e aproximo-a do pensamento que estou construindo: a denarcização seria esse descolamento do apego a uma realidade em particular, seria uma desidentificação; ou, numa construção analógica e vista em outro plano, seria, no sentido estrito de Derrida, uma desconstrução.
} 
está em pauta. Pais em conflito com seus filhos podem dizer, perante uma câmera de TV ou na sala com os amigos, que aprenderam muito com as novas gerações mas isso é, via de regra, uma racionalização ou uma hipocrisia ou ambos, assim como amantes podem fazer muita literatura sobre como o amor é lindo e nos faz crescer o que, na prática, não significa um único passo além do autoelogio. O leitor não deve crer que é disso que se trata aqui.

Há um paralelo entre a relação do homem com Deus e com o outro. Se, na primeira, como vimos, o lugar do Maior abre espaço para o alargamento do sujeito, na segunda, o modelo excelente também é uma via de ampliação. As relações cordiais, de amor e de amizade, são tecnicamente lugares de aprendizado e de crescimento reais, não teóricos. 0 termo chave é "técnica" e o hábito mental "ocidental" nos dificulta a compreensão da sua real aplicação no contexto. Saber colocar-se num lugar em que o outro é um modelo excelente exige uma disciplina, uma constância e muita técnica, do que tratarei na $3^{a}$. parte deste trabalho.

Finalmente, a alma, ou o ego, torna-se o coração e o Corão a chama de "alma pacificada". A dualidade torna-se unidade, não por uma redução mas, ao contrário, por um alargamento.

É importante ter em mente que essa dualidade, como vimos, é "circular" e, como tal, encerra todas as possibilidades de relação entre a alma e o coração, portanto, inclui qualquer pensamento ou intuição ou experiência a respeito. É dessa maneira que, quando um autor sufi apresenta uma consideração qualquer, seu objetivo primeiro é "fazer aparecer" por meio de uma dualidade-síntese, uma circunferência de modo que o seu leitor possa fazer um percurso singular e criar os seus próprios lugares nesse campo. Como a dualidade, a circunferência também é uma síntese. Na realidade, não se trata apenas de fazer aparecer uma circunferência e sim qualquer figura que comporte uma relação, sendo a circunferência a figura que, simbolicamente, encerra todas as demais. A utilização dessas figuras-síntese permite que cada "visão" seja integrada e articulada às outras, desse modo, um trânsito complexo de relações se estabelece e, a qualquer momento, é possível fazer novas montagens. Novamente, a imagem do caleidoscópio se põe: há uma independência inegável entre cada montagem produzida pelo arranjo geométrico entre as peças, no entanto, cada montagem remete à outra, pela via da linguagem geométrica, de modo que é possível passar de uma à outra: há ruptura e continuidade, sem que uma anule a outra. Assim, ao meditar sobre uma relação qualquer, o leitor-viajante irá, em algum momento, "encontrar-se" com uma infinitude de outras possíveis relações porque esta meditação 1) não é uma atividade do pensamento, é uma atividade "acoplada", na qual o "corpo" e os órgãos sutis estão envolvidos; 2) não é feita num momento isolado, como resultado de uma prática que busca "um efeito", é o resultado de um processo, de onde vem a idéia de "Via espiritual" ou de "Caminho", que implica não só que o entendimento de uma questão seja singular mas também que este entendimento seja aquilo que é importante para este sujeito em particular e igualmente para o caminho ou processo que ele está construindo neste momento. 
Além disso, esse entendimento singular não é "subjetivo" porque, além de ser importante para a via de um sujeito, ele é também a "explicitação" de uma nova relação. Como, no Mundo Encantado, os sujeitos estão postos em "totalidades", cada relação traz em si uma abertura para o Total, portanto, cada relação explicitada é também uma via de meditação para "o outro". Em outras palavras, um entendimento singular de um sujeito é uma explicitação de uma conversa com o Outro, portanto, fala com todos os outros, não é individual nem particular.

Pensando numa prática educacional, tais considerações e suas consequências tornam-se fundamentais.

Resta lembrar que, se consideramos a totalidade no seu sentido moderno e pós-moderno, ela é radicalmente diferente da que é considerada na perspectiva sufi. Para esta última, a totalidade, não sendo apenas uma idéia mas sendo um fundamento simbólico - portanto uma estrutura propiciatória ao mesmo tempo que uma meta a ser atingida -, é um dos modos de se criar um ambiente físico, anímico e espiritual que ofereça a experiência do trânsito e da mobilidade, da plasticidade e da flexibilidade, da transformação e da recriação disso que, sinteticamente, chamamos de realidade. Nesse caso, o real, sendo total, é outro mas não é exclusivamente outro. Sendo total, ele pode ser qualquer coisa, inclusive, o sujeito.

Evidentemente, o homem, visto como ego, não pode ter a experiência da totalidade, o que ele experimenta é a falta e/ou a obturação da falta. Se ele crê ter uma experiência ou uma idéia de totalidade é porque ele ou, no âmbito individual, necessita "preencher" imaginariamente essa falta ou, no âmbito político, pretende fornecer as bases para um totalitarismo. Nesse caso, a totalidade é ilusória. No entanto, a totalidade simbólica deve ser vista como uma alteridade fundante: porque o Outro (Deus) é total, o homem pode, do lugar da falta, ser diferente de Deus e, com isso, compor uma dualidade. O movimento seguinte, no qual o homem é igual a Deus, que só a perspectiva mística considera, é "fruto" dessa dualidade, pois, como vimos, a dualidade não é um antagonismo, ela exige que alternemos as posições. Grosso modo, se partimos da diferença, nosso caminho - de ida e volta - será em direção à igualdade e vice-versa, passando por várias posições conforme o nosso destino ${ }^{130}$. Nesse sentido, a dualidade operativa tem a capacidade de funcionar como uma estrutura fundante da realidade. Para isso, ela não pode, de modo algum, ser um antagonismo naquilo que este possui de rigidez e de "verdade" ou "certeza". A alma instigadora do mal tornar-se-á pacificada num processo de abandono das certezas e de pacificação no movimento. Eis por que a alma pacificada, aquela que tornou-se idêntica ao coração, é a culminação de um caminho. O que exige de nós um novo mergulho no oceano do Encantamento.

A maior heresia compreendida pelos doutores da lei judeus, cristãos e muçulmanos porque há muitas "heresias" proclamadas pelos místicos que sequer são notadas, quanto

${ }^{130}$ O termo será explicado. 
mais compreendidas - reside na afirmação da possibilidade de uma relação dual entre o homem e Deus na qual Deus pode ser visto como dependente do homem.

Antes de prosseguir, façamos um exercício de imaginação. Se pudermos desvincular-nos totalmente dos "conteúdos" que condicionadamente atribuímos aos termos "Deus" e "homem" e ficarmos apenas com a estrutura por detrás deles, isto é, se pensarmos que se trata de elaborar uma construção na qual o que é infinito, impensável, inabarcável, etc. depende do que é finito, tangível, etc., devemos começar por supor que deva tratar-se de uma construção extremamente complexa. Em primeiro lugar porque, vale insistir, não se trata de uma construção mental, que podemos fazer por meio do trabalho filosófico: o místico "pensa" com "faculdades cognitivas" (ver termo em árabe), com órgãos de percepção sutil (lataif), com alusões sutis (isharât), desvelamentos (kashf), intuição (idem), entre outros. Em segundo lugar porque não se trata de uma construção mas, sim, de inúmeras. Em terceiro, porque o infinito não cabe no finito.

"[referindo-se ao Corão] A aparente incoerência de tais textos - como o Cântico dos Cânticos ou certas passagens de São Paulo - tem sempre a mesma causa, a saber, a desproporção incomensurável entre o Espírito, de um lado, e os limitados recursos da linguagem humana, de outro: é como se a linguagem coagulada e pobre dos mortais se partisse, sob a formidável pressão da Palavra celeste, em mil pedaços, ou como se Deus, para exprimir mil verdades, dispusesse apenas de uma dezena de palavras..."131

"Quanto à "estreiteza" e ao aspecto restritivo da imaginação, isso se deve a que ela não pode receber nada - sejam coisas sensíveis ou espirituais, ou relações e conexões, ou a Majestade de Deus e Sua Essência - a não ser por meio de alguma forma. (...) De maneira que a imaginação é o mais extenso de todos os objetos do conhecimento e, no entanto, apesar da imensa amplitude de sua capacidade, que se estende sobre todas as coisas, é incapaz de receber as realidades (noéticas) puramente imateriais (sem fazer uso de alguma imagem ou semelhança)."132

Assim, a "descida" do novo produz seja um desarranjo, seja uma incoerência, seja uma ruptura no discurso estruturado do simbólico. De certo modo, podemos conceber esse novo como "uma mexida" no caleidoscópio que desarranja uma figura geométrica e, ao mesmo tempo, faz aparecer uma outra, totalmente diferente e, nesse caso, instaura-se um novo simbólico, como ocorre, por exemplo, no advento de uma nova Revelação. Diferentemente do que ocorre no âmbito religioso, para a Mística, a Revelação não aconteceu uma só vez, não é uma realidade fora da vida atual: ela acontece a todo momento no coração de cada fiel. Ela é um movimento no caleidoscópio. Quem produz esse movimento? Deus. Quem é Deus? É tudo. O que é o simbólico? É a diferenciação no tudo. O que é o sujeito? É o lugar onde o tudo se re-diferencia. O que é o imaginário? É a função de cristalização do simbólico, que dá forma perceptível ao simbólico. O que é o Real? É um dos

\footnotetext{
${ }^{131}$ Schuon, Comprendre L'Islam, op. cit., p 48.

132 Ibn 'Arabî, cit. e trad. Morris, J., in Postdata, op. cit., p. 47.
} 
nomes de Deus ${ }^{133}$. Mas, o lugar onde o tudo se re-diferencia não é o próprio tudo? É. Então, Deus é idêntico ao sujeito? Não, entre eles há diferença.

A relação entre Deus e o homem, ou entre o coração e o ego, ou entre a singularidade e o sujeito é, como dualidade operativa, um conjunto de possibilidades técnicas por meio das quais o sujeito acessa lugares nos quais se põem a realidade atual, a renovação, a descoberta de algo até então impensado, a criação singular, o portal para um novo universo de construções possíveis.

Dito de outra maneira, a dualidade indica que há o "um" e o "outro". Entre ambos, há diferença, não identidade. Essa diferença entre é o lugar singular. Do lugar singular, o um pode ser outro, o ego pode ser coração e o homem pode ser Deus. É nesse sentido que, para a Mística e, especialmente, na formulação de Ibn 'Arabî, a singularidade não é um conjunto de experiências adquiridas nem é construída historicamente, embora ela possa emprestar-se de atributos e experiências e possa construir-se historicamente sem que isso a esgote. Dito ainda de outro modo, a singularidade não é um atributo do homem, ela é um lugar. E não um lugar individual, "próprio" ou "pertencente" a alguém. Ela é um lugar que só existe na atualidade, ela é um acontecimento que acontece em alguém, mas, nessa hora, esse alguém já não é um indivíduo. O homem não possui uma singularidade, ele não é singular, mas ele pode ocupar um lugar singular. Cada vez que um sujeito contempla em si algo novo, "que ninguém antes dele havia contemplado", quer dizer que ele encontrou um lugar singular.

Sob certos aspectos, é possível dizer que este lugar é como uma clareira na floresta à qual se chega por um determinado caminho. Nesse caso, quando o viajante se encontra em outra parte da floresta, ele não sabe mais como chegar à clareira e, então, ele é aquele a quem Merlin se refere ao dizer "it is the doom of men that they forget" ${ }^{134}$. Sob outros aspectos, a floresta é encantada e faz com que a clareira se mova constantemente pois um lugar singular não é um a priori, não existe se não for construído, mas tampouco se pode dizer que ele seja efeito dessa construção. Se é singular, não pode ser efeito de nada. Ele é como "uma escada cujos degraus vão se pondo à medida em que se sobe" porque ele é puro ato, sem potência que lhe seja proporcional.

Há uma desproporção na singularidade porque ela rompe com os véus interpostos entre Deus e o homem. Na atividade natural, a Potência divina vai sendo ocultada progres-

\footnotetext{
${ }^{133}$ Como o leitor pode facilmente notar, simbólico, imaginário e real aqui já não têm nada que ver com o RSI lacaniano.

${ }^{134} \mathrm{O}$ tema do esquecimento é tradicional e aparentemente muito conhecido. No entanto, a idéia de que o homem esquece um conhecimento "já pronto", "já dado", independente de sua própria experiência e que é esse conhecimento que se trata de "relembrar" não corresponde à perspectiva mística. O que o homem esquece frequentemente é o "caminho" (os caminhos, cada caminho) que o leva ao lugar singular e, aqui, a questão torna-se aparentemente paradoxal: porque está marcado por eles, o coração conhece esses caminhos, como o ator conhece o drama inteiro, porém, o ego, como a personagem, deve descobri-los na experiência, deixando para isso iluminar-se pelo coração. Assim, criar, relembrar e descobrir são aspectos de um mesmo traçado.
} 
sivamente até chegar a ser expressa num ato humano. Na atividade singular, o "receptáculo" terrestre é torcido ante a pressão de algo que não se curva aos limites do tecido receptor. Pelo menos, esta é uma maneira "dual" de tratar a questão.

Quando Muhammad recebia uma sura do Corão, experimentava muitas vezes tremores "que um homem comum não suportaria". Sob certos aspectos, a descrição de um ato faIho - que, não raro, "sacode" o falante que se vê, subitamente, diante "de si mesmo" corresponderia analogamente a uma experiência singular, embora, nesse caso, este ato falho devesse ser descrito como irrupção do Real no seio do Simbólico (descrito por Ibn 'Arabî, como alâm al-mitâl, mundo das analogias, entre outros ${ }^{135}$ ), o que nos distancia da Psicanálise. E, muito distantes também de Derrida, deveremos dizer que o singular é uma ruptura na Escrita e é uma Presença, ainda que, na maioria dos casos, uma presença efêmera, após a qual a Escrita se rearranja, novamente, como num movimento do caleidoscópio.

Todavia, não devemos pensar nesta idéia de renovação como o elogio da criatividade "em si", como quer a moda. Não se trata de buscar "novidades", "novos diferenciais", "inovações atraentes", etc. Este "novo" corresponde sobretudo à perspectiva de relação com o "atual", isto é, a uma relação que sabe defender-se da fixidez, da padronização, do preconceito, do instituído. Ora, esta é uma perspectiva posta pelo Sufismo, o quanto ela é factível ou desejável para o cidadão do "nosso tempo" é uma discussão a seguir. Importa, antes disso, mapear adequadamente este aparente antagonismo ao "instituído".

Por que mudar? Por que desapegar-se? Por que ser outro? No âmbito filosófico, uma resposta possível à última pergunta seria: "Porque o homem é outro".

No âmbito pedagógico, estamos compreendendo porque os sufis insistem em mostrar aspectos limitantes da consciência e sistematicamente rompem com o que seria o núcleo da lógica ocidental, isto é, a noção de atributo ou de propriedade inerente a algo, sua natureza e sua identidade, e apontam para o grave equívoco de que ela pretenda ser a via única de transmissão do conhecimento.

Se, para o pensamento contemporâneo, a fixidez da identidade é uma ilusão que objetiva garantir uma "segurança", ainda que imaginária, ou que resulta no conforto do conhecido, para Ibn 'Arabî, a segurança, fruto da ilusão da permanência, é na verdade, conforme uma expressão corânica, um ardil divino (makri Allah) ${ }^{136}$ : Deus engana o homem pela segurança, pela certeza, pela fixidez, pelo repouso, numa palavra, pelo ego. E o ego tem muitas formas.

\footnotetext{
${ }^{135}$ Ver cap. 1.4.

${ }^{136}$ Sobre o makri Allah, ver Chodkiewicz, Le Sceau des Saints, op. cit., p. 208. A meu ver, trata-se da mesma perspectiva que vemos vislumbrada na fala de Riobaldo: "E outra coisa: o diabo, é às brutas; mas Deus é traiçoeiro! Ah, uma beleza de traiçoeiro - dá gosto!", Guimarães Rosa, Grande Sertão..., op. cit., p. 21.
} 


\subsection{UMA IDÉIA DE LUGAR}

Imagine uma situação em que o Luis, músico, assistiu a um show do Armando, músico de sucesso. Em que a Júlia, adolescente, viu o vestido que a Manuela comprou prá festa de hoje à noite. Em que o César, gerente de marketing, viu a apresentação que a Malu, igualmente gerente, fez para a diretoria. Em que o Seu Carlos ficou na praia observando como o seu neto encantava a namorada com o seu corpo saradão.

Algumas pessoas chamariam de inveja a esse movimento interno que às vezes é uma espécie de aperto em alguma parte aqui dentro, acompanhado ou não de um muxoxo ou, quem sabe, um dar de ombros imperceptível: um misto de gosto pelo reconhecimento da qualidade do que se experimenta e desgosto pelo fato de aquilo não ser seu.

Outras pessoas nem perceberiam que esse movimento, que se apresenta de tão variadas formas, apresentou-se na alma com ares de quem veio prá ficar. Elas começam a maldizer "o outro" ou a situação, fazendo de conta que não gostaram do que viram ou ouviram ou provaram. Procuram fazer crer que estão objetivamente criticando algo de má qualidade, mas, a gente sabe, quem critica de fato usa mais substantivos que adjetivos, mais análise que condenação, mais indignação que raiva (embora, parodiando um mestre sufi, a diferença entre estas últimas seja mais difícil de detectar que a pata de uma formiga numa pedra preta numa noite sem lua).

Outras pessoas dedicaram bastante tempo de suas vidas a desenvolver uma autoobservação acurada. Graças a isso, conseguem flagrar-se em vários momentos permitindo as visitas da inveja, como autômatos, abrindo espaço para que ela se acomode no aconchego da lareira, das horas secretas, nas suas conversas íntimas com os próprios desejos. Ou pior, como pode acontecer com qualquer um de nós: você a percebe bebendo ao seu lado quando um amigo seu, um amigo do peito, mostra-se com uma de suas grandes qualidades e você, que sempre gostou daquela qualidade, acha ruim e deseja secretamente que ele a perca. $E$, nessa hora, você sabe, porque nada em você pode evitar que você sai- 
ba, que você acaba de vislumbrar uma paisagem do inferno. Assim como sabe que essa inveja vem regularmente, como o chantagista que você odeia e submissamente acolhe ou como o traficante que exige o dinheiro em cash.

A inveja é um lugar. Ao dizer isso, abandono uma possível definição de inveja - dado o fato de que as definições, em tempos pós-modernos, pelas mais variadas razões, tornaramse vãs, como outrora também o foram no Mundo Encantado.

Não interessa o que a inveja é. Ela não é nada, ela é um jeito - cada hora diferente - de nos colocarmos numa situação na qual acontece alguma coisa que é sempre a mesma mesmo que varie conforme cada pessoa. $\mathrm{O}$ que me interessa é esse efeito degenerativo que ela produz. Ela vai fazendo, aos poucos, com que, cada vez que uma pessoa entra nesse lugar, ela vá se apequenando: tornando-se incapaz de apreciar coisas dos outros; achando que as coisas boas só acontecem para os outros; desistindo de construir ações em torno de seus próprios talentos porque os outros não vão apreciá-lo como apreciam os talentos dos outros; desistindo de investir nos outros porque os outros não correspondem como deviam; etc.

É claro que muitas pessoas aprenderam alguns truques também. Quando, "acidentalmente" caem nesse lugar, chamam rapidamente por auxílio. A soberba, as racionalizações, a irresponsabilidade, há um sem número de "boas dicas prá você lidar com a inveja". A ideologia do winner é inteiramente pródiga no fornecimento desses anti-inveja. Alguns atuam diretamente no sistema nervoso, fazendo com que você não a sinta, outros fazem com que ela seja eliminada junto com a comida, outros fazem com que ela entre mais fundo na célula de modo que não apareça na pele, etc. Claro está que, nesse caso, ninguém precisou mudar de lugar. A inveja continua ali como sócia do clube e frequentadora assídua, só que algumas pessoas criaram modos de virar sócios também.

Agora, mudar de lugar é outra coisa. Em Nova York não tem Torre Eiffel, se você vai prá NY, você deixa a Torre Eiffel lá.

Não estou dizendo - evidentemente que não! - que podemos mudar de lugar como num passe de mágica e ficar livres daquilo que nos incomoda ou embota ou destrói.

O que estou dizendo é que, quando digo que a inveja é um lugar, estou também dizendo que ela não está em nós, na nossa história, grudada, fazendo parte da nossa natureza. Posso até dizer que ela não faz parte da nossa natureza porque não temos natureza alguma, conforme uma idéia de sujeito tanto mística quanto contemporânea.

Num certo lugar, a inveja está presente. Nesse lugar, a minha história é de um certo jeito, o mundo, os outros, Deus, etc. Num outro lugar, a minha história é outra, as coisas são outras. E a inveja pode não estar presente.

Vamos imaginar situações que falem disso. 1) Você está cansado, pressionado por um tra- 
balho difícil, arriscado, está tenso e vê alguém conseguindo alguma coisa que você queria. 2) Você está contente, acabou de receber uma promoção, está com uma passagem comprada prá Paris, teve uma noite de sexo sensacional e vê alguém conseguindo alguma coisa que você queria. Exatamente a mesma coisa é vivida de um modo muito diferente. Se eu chamo esse "modo muito diferente" de lugar, eu extraio disso consequências.

Agora, o ponto aqui é o seguinte: 3) Você está cansado, pressionado por um trabalho difícil, arriscado, está tenso e vê alguém conseguindo alguma coisa que você queria. Nesse momento, você aprendeu a mudar de lugar e, quando percebe que a inveja está tocando a campainha, você vai buscar no seu repertório lugares de melhor qualidade.

Conheço uma atriz que diz que é tão tímida que quase não consegue conversar com as pessoas, mas, quando está no palco, não sente timidez nenhuma. Conheço uma terapeuta que diz que quando está com um paciente, nunca estranha ou julga um comportamento, é o que ela chama "estar na pessoa jurídica"; quando está "na pessoa física", diz ela, é impaciente com qualquer um. Conheço uma professora que se diz muito crítica com as pessoas mas, quando está com seus alunos, seu "peito enche de leite" e só lhe interessa desenvolver suas qualidades. As pessoas são as mesmas, mas aqui nós as estamos olhando em diferentes lugares.

Notemos agora uma coisa importante: não estou dizendo que "a inveja é um lugar" para dizer algo como: "tudo o que existe é lugar", "a realidade são lugares", ou, "de agora em diante, não vamos mais pensar em história porque história é tempo e isso é uma abstração". Obviamente, há lugares em que a história pode ser abstrata, outros em que aparece como concreta. Novamente: não estou definindo inveja, ao dizer que ela é um lugar, minha intenção é propor um modelo mental de operação com a inveja. Não é descrevê-la, não é falar dela. Minha intenção, claro, é falar de outra coisa.

Se eu invento que a inveja é um lugar, minha primeira pergunta não deveria ser: "como eu faço prá mudar de lugar?". Antes, preciso saber para qual lugar eu quero ir.

Nesse caso, a pergunta pode ser: "o que eu quero experimentar no lugar da inveja?". E então eu vou começar a construir essas outras possibilidades.

Não adianta, é claro, eu começar a dizer: "ah, no lugar da inveja eu quero sentir amor, admiração, etc." porque isso é novamente uma generalização, ou uma abstração ou uma racionalização ou uma bobagem. Há situações em que é melhor sentir raiva que amor, todo mundo sabe disso. Daí, outra vantagem da idéia de lugar: a pergunta é: nessa situação, nesse contexto, com essas pessoas, com o meu momento, agora eu quero....

Ou, se a situação já passou, você pode se perguntar: "o que eu poderia ter feito? como poderia ter-me sentido? O que eu gostaria de ter experimentado?".

Digamos que, ao fazer isso, ocorra a você que poderia ter sido bom se você tivesse respi- 
rado melhor e mais fundo, que isso teria trazido um relaxamento maior, e você teria se ajeitado melhor na cadeira, ficado mais confortável e percebido que, por automatismo, você estava se deixando abater por certos problemas e perdendo contato com o gosto daquela situação e, ao dar-se conta e mudar de posição, você fez um novo contato, alimentou-se de algumas coisas da situação e abriu-se para um aprendizado novo.

Ou ocorra a você que havia algo a ser melhor observado, uma coisa que tem-se repetido com frequência e que você quer examinar melhor, na sua análise, junto com o seu homeopata ou na sua meditação budista. E, ao se dar conta disso, você mudou de posição, fez um novo contato com a situação, alimentou-se de algumas coisas e abriu-se para um aprendizado novo.

Ou ocorra a você que - por exemplo, se você sentiu inveja naquele momento em que as pessoas deram uma atenção especial ao seu amigo e ele te pareceu tão brilhante e cheio de graça - na verdade, você estava sentindo falta de alguma coisa. E você então começou a se observar ali naquela situação, vendo, olhando, buscando que falta era aquela, e você, por exemplo, percebeu que queria alguma coisa daquelas pessoas. E depois percebeu que isso que você queria, embora sem saber ao certo o que era, você queria de qualquer pessoa, não só daquelas. E que você queria isso sempre, em qualquer lugar. E então você foi passando por outras situações e percebeu que tinha uma idéia muito vaga desse seu querer: era algo, com qualquer um, a qualquer momento e com qualquer pessoa. E então você se disse que, em algumas situações, não todas, quando essa grande falta aparecia, vinha também a inveja. Ou a inveja aparecia e vinha a falta, sei lá. $E$, então, como num salto sutil, você passou a se dar conta de que em outras situações, muito diferentes, vinha a falta também, mas, nessa hora, por alguma razão, acontecia alguma coisa entre você e aquelas pessoas ou aquela situação que conversava com aquela falta - não prá fazê-la desaparecer, mas prá dar a ela uma forma particular, daquele momento, com aquelas pessoas. E você realizou que aquilo que se chamava os outros podia, sob certas circunstâncias, chamar-se cada um. E, ao se dar conta disso, você mudou de posição, fez um novo contato com a situação, alimentou-se de algumas coisas e abriu-se para um aprendizado novo.

Bem, aqui você realizou uma coisa importante: muitas vezes, ao conseguir estabelecer uma relação com cada pessoa em particular, uma relação presente, que pode durar apenas alguns segundos mas que tem de fato a ver com aquela pessoa e com você, você não sente que haja lugar para nenhuma inveja vir visitar.

Agora, é claro, não precisa generalizar. Não é necessário sair por aí dizendo que "a inveja é a nossa incapacidade de fazer um contato real e atual com cada um em particular de modo a perceber que toda falta é uma negação do outro naquilo que ele possui de único." Embora, às vezes, essa "definição" possa ser útil, não é necessário dizer isso sobretudo porque há situações em que isso absolutamente não se dá desse modo.

Com a idéia de lugar, conservamos o momento, o contexto e toda a vida que está aconte- 
cendo ali, o cada um de cada coisa. Há todo um conjunto de idéias, crenças, valores, memória, experiência, desejo, recurso, sentimento, etc. que estão acontecendo, presentes naquele lugar. Há pessoas inteiras se dizendo ali. Portanto, não é que você quer deixar de ter inveja de um modo geral, é que você quer poder saborear as diferenças das situações e das pessoas.

Assim, depois de um tempo, você sabe por experiência que há um lugar, que você conhece bem, no qual a inveja aparece e se instala. Há um outro, em que você experimenta uma outra possibilidade e, nesse caso, a inveja não aparece. E há um outro em que você inventa alguma coisa nova, descobre alguma coisa nova que ocupa o lugar daquela inveja. Como todos esses lugares estão dentro de você, você começa a perceber que a sua memória pode ser uma ferramenta muito útil. Se você está num lugar em que a inveja se sente à vontade e você não, você pode se lembrar dos lugares mais interessantes que já conheceu dentro de você e "ir" para eles.

Sim, há técnicas para fazer isso. Algumas mais sofisticadas, outras mais modestas. O trabaIho com os modelos mentais, que será examinado na 3a. Parte deste trabalho, é um conjunto que abarca algumas delas. O trabalho com os contos da tradição oral (capítulo 2.7) é outro. E, claro, há muitos outros. Não são técnicas de mudança de comportamento, são técnicas de mudança de lugar e isso é absolutamente fundamental.

Finalmente, além da inveja, há muitas outras drogas no mercado. Eu diria que o que foi dito acima também vale para todas elas. Desde, é claro, que se levem em conta as diferenças. O que me permite falar de mais uma vantagem da idéia de lugar. Mais que uma idéia, trata-se de uma imagem: o que importa não é você, não é o outro, não é a virtude nem o vício, não é uma coisa. O que importa é tudo junto sendo visto na relação que cada coisa tem com as outras naquele momento. Porque, em outro momento, é outra relação e são outras coisas. Então, falar em lugar é um modo de já colocar o momento na memória - não prá fixá-lo lá, mas prá guardá-lo num lugar. O momento a gente não traz de volta, mas o lugar sim. "Eu estive naquele lugar, posso voltar lá, ele é assim, assim, etc."

Agora, há uma estrutura básica por trás dessa idéia de mudança de lugar. Trata-se de desapegar-se de um lugar, abandoná-lo para dirigir-se a outro.

Em contos antigos das mais variadas partes do mundo, as referências ao tema da viagem não são poucas. O príncipe que abandona o castelo de seu pai por sentir-se incapaz de vencer um desafio, a esposa que assume outras identidades a cada cidade em que o marido se encontra, o derviche errante, o buscador da verdade, o peregrino, o caminhante, o navegante, o andarilho. Antes de falar no desapego "das coisas materiais" - como quer a tradição da ética protestante - o viajante desapega-se dos lugares em que sua alma não pode crescer e lança-se não apenas na descoberta mas, sobretudo, na fundação de novas terras. A "vasta terra de Deus", tal como descrita no Corão, é, segundo Ibn 'Arabî, o Mundo da Imaginação (al-alâm al-ḩayâl) ${ }^{137}$.

\footnotetext{
${ }^{137}$ Ver adiante, capítulo 2.13.
} 
Como um grande mestre do Sufismo, Ibn 'Arabî leva a experiência imaginativa às suas últimas consequências. Não se trata simplesmente de combinar imagens tiradas do mundo conhecido e da história pessoal. O que está em jogo no alâm al-hayâal é o desenvolvimento da capacidade de ser um outro a cada instante e de ver o mundo como uma recriação a cada instante.

Não obstante, podemos falar, em proporções muito mais modestas, numa criatividade intimamente ligada ao trabalho sobre si mesmo, aos processos de construção de autonomia e aprendizado, ao conhecimento-invenção de cada outro.

Criatividade como perspectiva de criar lugares com maior riqueza de detalhes. Nos quais cada outro ganha as cores e a vida de uma experiência atual. Se a inveja é uma forma de abstrair-se das situações e ficar grudado no vazio e na desesperança do contato verdadeiro com alguma coisa que valha a pena, a viagem por dentro do outro é uma forma de inventar o que valha a pena.

A idéia de lugar está, portanto, profundamente implicada na idéia de imaginar o outro, imaginar outra situação, imaginar a si mesmo, imaginar-se como outro. É levantar a âncora e lançar-se a outros mundos, pois não há porque ficar amarrado à crença de que "eu sou assim". Nesse lugar você é assim, em outro lugar você é de outro jeito.

Quando aplicamos rótulos às situações e aos outros, quando dizemos "eu te conheço" ou "as pessoas são...", quando cedemos ao vício planetariamente endêmico de generalizar (perceberam que esta é uma generalização?), tudo isso também é um tipo de imaginação, no sentido de que é uma invenção nossa, tirada da nossa cabeça. Só que se trata de uma imaginação pobre, sem gosto.

Quando, ao contrário, partimos em viagem para fundar novos lugares, somos colocados diante do desafio de imaginar o outro de modo mais extenso. Nessa hora, as coisas que vemos, ouvimos, sentimos, são material de inspiração.

Daí essa possibilidade: imaginar-se em outros lugares, construir imaginariamente outros lugares, a construção imaginária sendo, ao mesmo tempo, muito duradoura e totalmente evanescente. 


\subsection{UMA CERTA CONCEPÇÃO DE POSIÇÃO IMAGINÁRIA}

Utilizo a expressão "posição imaginária" como sinônimo de "lugar". A diferença entre uma e outro é que o lugar indica a mobilidade, o desapego, a possibilidade de ir para outro lugar; a posição imaginária indica todo o conjunto imaginário que preenche cada lugar: as crenças, o que se vê, para onde se olha, os modos de agir e de experimentar, etc. "Posição imaginária" e, mais adiante, "formação discursiva" são expressões que extraio da Psicanálise para propor utilizá-las nesse contexto de um modo "torcido", conforme as necessidades das considerações que se seguem.

A idéia de posição imaginária, que passo a utilizar como um termo de referência, pode ser pensada, aqui, do seguinte modo. Imaginemos uma personagem: uma mulher, 35 anos, graduada em administração de empresas e pós-graduada em comunicação. Recentemente, fez um "frila" prá uma consultoria sobre sustentabilidade e programas de impacto social e ficou apaixonada pelo tema. Um de seus assuntos prediletos tem sido a desigualdade e as propostas para abrandá-la, bem como a justiça, o respeito ao outro, a tolerância e a aceitação da diversidade. Ela está agora fazendo "reflexo" num cabelereiro novo e acaba de reclamar do ar condicionado. O profissional é evasivo, não se prontifica a diminuir o ar, dá uma desculpa qualquer. Depois de algum tempo, ela insiste, sem resultado. Enfurecida, indignada, ela decide não mais voltar ao salão, deixando claro aos presentes que perderam uma cliente por má conduta profissional. Seus motivos: o salão não é costumer oriented, não percebe os direitos (sic) do cliente, "não faz um bom atendimento, o que, hoje em dia, é fundamental e todo mundo sabe disso".

Normalmente, nas conversas entre sushis, nossa personagem proclama seu interesse pelo "outro". Ao fazer reflexos, ela supõe que é seu direito exigir que homens trabalhem sob forte calor porque uma "cliente" está desconfortável. Mas não é direito do profissional que a atende, no caso, o cabeleireiro, ter, igualmente, a sua dose de conforto. A palavragatilho "cliente" dispara uma posição imaginária diferente da que é disparada pela prazeirosa repetição das bandeiras da sustentabilidade, entre sushis. Todo o cenário, os outros, 
as idéias, as reações, as crenças, as identidades, os sentimentos, o metabolismo, a memória: tudo nesta mulher é diferente conforme a posição imaginária em que ela se encontra. Não se trata de incoerência, nem de hipocrisia, termos anacrônicos no presente contexto. Não interessa aqui o julgamento ético da personagem. Interessa o fato de que, para ela, não há descontinuidade entre uma posição e outra, nem diferença. Tudo se passa, para ela, como se se tratasse de um único cenário, abrigando uma única pessoa, uma única personalidade e um único sistema de crenças. Eventualmente, ela seria até mesmo capaz de justificar seus atos a partir de uma racionalização qualquer que os legitimasse perante "a sustentabilidade". No entanto, até mesmo algumas de suas mais caras histórias infantis são contadas de modo diverso, conforme o ambiente imaginário em que ela se encontra e isso é facilmente notável por qualquer um que conviva com ela.

Igualmente, é natural para toda a audiência do programa televisivo "O Aprendiz", que a sua "estrela", um empresário de sucesso, humilhe de modo sistemático os participantes do programa, submeta-os pelo medo e os instigue a praticar todos os preceitos de um "capitalismo selvagem", agindo exatamente como qualquer personagem que, na novela de outro canal, seria considerada "do mal". Diante da novela, a audiência condena esses atos, no programa, a audiência os exalta.

Outro exemplo. Imaginemos a seguinte situação:

Maurício chega em casa mais animado que de hábito, disposto a fazer o jantar. Sua muIher está vendo novela na sala. Ele vai à cozinha para ver o que tem de ingredientes, já imaginando uma comidinha saborosa. Constata que a geladeira está praticamente vazia e se lembra: amanhã é dia de feira, portanto, hoje é dia de um lanche simples, ou uma sopa. Decepcionado e meio sem pensar, comenta: "que pena, a geladeira está vazia..."

Ingrid, da sala, ouve o comentário e pensa: "ele já está me criticando, nem chegou em casa e já começou. Eu já falei mil vezes prá ele que a feira é amanhã mas ele não consegue não por a culpa em mim prá tudo! é por isso que eu fico vendo novela e nem ligo quando ele chega, mas aí ele sente..." $E$, enquanto esses pensamentos a invadem de enxurrada, ela balbucia como que distraidamente: "É..."

Maurício a ouve e pensa: "É?, é tudo o que ela me diz? eu tô aqui no maior empenho, morrendo de fome, a fim de fazer uma comida legal prá gente e ela só consegue pensar em novela. Mulher é um bicho estranho mesmo...".

Poderíamos dizer que em todas as situações há sempre diversos níveis de diálogos visíveis e invisíveis. Cada nível corresponde a uma posição imaginária em que se põe o sujeito.

Se Maurício pudesse observar-se em alguns níveis, partindo dos discursos psicológicos vigentes atualmente, ele poderia dizer:

"Eu queria fazer o jantar. Num nível, meu desejo era seduzir minha mulher, mostrar-lhe 
que eu sou um cara incrível que, além de trabalhar ainda chego em casa e faço o jantar e que, portanto, ela pode considerar-se uma mulher de muita sorte, etc. Noutro nível, eu queria que ela me perdoasse por ganhar tão pouco, por não podermos fazer aquela viagem combinada, porque, no fundo eu sou um cara fraco, que não consigo me impor no trabalho e ela não deu muita sorte de ter casado comigo. Noutro nível, eu me lembrei daquele dia em que a gente se conheceu e ela fez um jantar cheiroso e estava linda e a gente tomou aquele vinho e transou na sala e, no fundo, eu vi que podia acontecer de novo, bastava ter boa vontade e recomeçar... Noutro nível, eu tinha acordado de manhã com uma sensação estranha, tinha sonhado com o meu pai que, no sonho, não tinha morrido, tinha sido um engano e passei o dia lembrando vagamente do sonho, sempre com aquela sensação e parecia que tudo estava tão diferente que eu quis experimentar uma coisa nova, pensei em fazer o jantar, criar uma situação agradável, usar minha energia para interagir com minha mulher, eu me sentia um cara novo..."

Quantos níveis mais haveria não importa. A cada vez que Maurício olhasse de novo para a situação com uma certa desenvoltura, novos níveis apareceriam (novamente: como numa escada em que os degraus aparecem conforme se sobe). O importante é que todos esses níveis são imaginários e o sujeito está virtualmente em todos eles.

Com o trabalho de observação, o que esse sujeito pode fazer é imaginar/observar níveis e, com isso, construir posições imaginárias, inventar possibilidades.

Uma consequência importante disso é que deixamos de pensar em personalidades ou estruturas de personalidades e passamos a ver sujeitos em deslocamento constante e, por essa via, começamos a pensar uma pedagogia que já não busca mais instaurar crenças de identidade, portanto, crenças abstratas e autolimitantes.

Outra consequência importante é que resgatamos o valor de uma interioridade no sentido encantado do termo: um "lugar" que se esvazia a todo momento e busca novos aprendizados, possuindo para isso recursos de todo tipo.

Vejamos agora uma formulação encantada a respeito, num texto de Amadou Hampâté Bâ ${ }^{138}$.

Nas tradições fula e bambara dois termos servem para designar a pessoa. Para os fulas, são eles Neddo e Neddaaku. Para os bambaras, Maa e Maaya. As primeiras palavras significam "a Pessoa" e, as segundas, "as pessoas da pessoa".

A tradição ensina que existe antes Maa, a "Pessoa receptáculo", e depois Maaya, ou seja, os diversos aspectos de Maa contidos no Maa-receptáculo. Como diz a expressão bambara Maa ka Maaya ka ca a yere kono: "As pessoas da pessoa são múltiplas na pessoa". Encontramos exatamente a mesma noção entre os fulas.

A noção de pessoa é, portanto, a princípio, muito complexa. Implica uma multi-

\footnotetext{
${ }^{138}$ Escritor malinês (sec. XX), discípulo do sufi Tierno Bokar.
} 
plicidade interior de planos de existência concêntricos e superpostos (físicos, psíquicos e espirituais, em diferentes níveis), bem como uma dinâmica constante.(...)

Em nenhum momento a pessoa humana é considerada como uma unidade monolítica, limitada a seu corpo físico, mas sim como um ser complexo, habitado por uma multiplicidade em movimento permanente. Não se trata, portanto, de um ser estático ou acabado.(...)

Maa-Ngala (ou Deus-Mestre) autocriou-se. Depois criou vinte seres, que constituiriam o conjunto do universo. Mas ele apercebeu-se de que, dentre essas vinte primeiras criaturas, nenhuma estava apta a tornar-se seu kumanyon, isto é, seu interlocutor. Então, recolheu um pedaço de cada uma das vinte criaturas existentes. Misturou tudo, o que serviu para criar um vigésimo primeiro ser híbrido, o homem, ao qual deu o nome de maa, ou seja, o primeiro nome que compõe seu próprio nome divino.

Para conter maa, o ser todo-em-um, Maa-Ngala concebeu um corpo especial, vertical e simétrico, capaz de abarcar ao mesmo tempo um pouco de cada um dos seres existentes. Este corpo, chamado fari, simboliza um santuário onde todos os seres se encontram em circundução ${ }^{139}$. É por isso que a tradição considera o corpo do homem como o mundo em miniatura, conforme a expressão Maa ye dinye merenin de ye, isto é: "O homem é o universo em miniatura".

O corpo inteiro corresponde a um simbolismo bem preciso. A cabeça, por exemplo, representa o estágio superior do ser, perfurada por sete grandes aberturas. Cada uma delas é a porta de entrada de um estado de ser, ou mundo, e é guardada por uma divindade. Cada porta dá acesso a uma nova porta interior, e esta, ao infinito. $O$ rosto é considerado como a fachada principal da morada das pessoas profundas de Maa. Sinais exteriores permitem decifrar as características dessas pessoas. "Mostre-me seu rosto, e eu the direi a maneira de ser de suas pessoas interiores", diz o adágio. Cada ser interior corresponde a um mundo que gira em torno a um eixo ou ponto central.

O psiquismo do homem é, portanto, um conjunto complexo. Como um vasto oceano, sua parte conhecida não é nada comparada à ainda por conhecer. $\mathrm{O}$ ditado malinês é eloqüente a esse respeito: "Nunca se acaba de conhecer Maa..."

Por que esta complexidade?

De um lado, o nome divino do qual Maa é investido confere-lhe o espírito, e o faz participar da Força Suprema. Esta chama-o à sua vocação essencial: tornar-se o interlocutor de Maa-Ngala. De outro, os diversos elementos que estão nele o tornam depositário de todas as forças cósmicas, tanto as mais elevadas como as mais baixas. A grandeza e o drama de Maa consistem em ser ele o lugar de encontro de forças contraditórias em perpétuo movimento, que somente uma evolução bem realizada no caminho da iniciação lhe permitirá ordenar, ao longo das fases de sua vida.

As forças múltiplas e variadas que se movem no universo dissimulado de Maa

\footnotetext{
${ }^{139}$ Rotação de um membro em torno de sua inserção no tronco, conforme um cone, do qual a articulação
} forma o vértice. 
constituem os estados, ou pessoas psíquicas, emanadas do espírito do próprio Maa. O Espírito, princípio imaterial e imortal, não é um ser imaginário. Ele existe. É ele que dá nascimento à Imaginação, faculdade bem real (não confundir com o imaginário), graças à qual Maa torna-se capaz de visões e de relacionamento com espíritos ou seres que habitam fora dele ou fora do mundo visível. Para retomar uma expressão de meu amigo Boubou Hama, ele "concretiza o abstrato", que assume imagem e forma. O espírito de Maa permite-lhe conhecer, compreender e reforçar sua atenção. Desenvolvendo essas aptidões, Maa torna-se capaz de julgar.

A pessoa, assim, não está encerrada sobre si mesma, como uma caixa bem fechada. Ela se abre em diversas direções, diversas dimensões, poderíamos dizer, ao mesmo tempo interiores e exteriores. Os diversos seres, ou estados, que estão nela, correspondem aos mundos que se escalonam entre o homem e seu Criador. Eles estão em relação entre si e, através do homem, em relação com os mundos exteriores. Antes de tudo, a pessoa está ligada a seus semelhantes. Não se saberia concebê-la isolada ou independente. Assim como a vida é unidade, a comunidade humana é uma e interdependente.

Devido a esse sentimento profundo de unidade da vida, a pessoa humana não é destacada do mundo natural que a cerca. Mantém com ele relações de dependência e equilíbrio, codificadas por regras de comportamento ensinadas pela doutrina tradicional Bembaw-sira. Leis precisas determinam a conduta do homem face a todos os seres que povoam a parte vital da terra: minerais, vegetais e animais. Essas leis não podem ser violadas, sob pena de provocarem, no seio do equilíbrio da natureza e das forças que a sustentam, uma perturbação que se voltaria contra ele.

A noção de unidade da vida é acompanhada pela noção fundamental de equilíbrio, de troca e de interdependência. Maa, que contém em si um elemento de todas as coisas existentes, é chamado a tornar-se o fiador do equilíbrio do mundo exterior, e até mesmo do cosmos. Na medida em que reintegra sua verdadeira natureza (a do Maa primordial), o homem surge no mundo como o eixo convocado a preservar a multiplicidade exterior de cair no caos.

Assim, da boa ou má conduta dos reis ou chefes religiosos tradicionais, dependerá a prosperidade do solo, o regime das chuvas, o equilíbrio das forças da natureza etc.

Enquanto o homem não tiver ordenado os mundos, as forças e as pessoas que estão nele, ele é o Maa-nin. Ou seja, um tipo de homúnculo, o homem ordinário, o homem não realizado. A tradição diz: Maa kakan ka sé $i$ yere la naate a be to Maa ni yala. Isto é: "Não podemos sair do estado de Maa-nin, para reintegrar o estado de Maa, se não formos o mestre de nós mesmos".

Para concluir, chamarei a atenção sobre o fato de que a tradição se ocupa da pessoa humana enquanto multiplicidade interior, inacabada no princípio, chamada a ordenar-se e a unificar-se, como a buscar seu justo lugar no seio das unidades mais vastas, que são a comunidade humana e o conjunto do cosmos.

Síntese do universo e confluência das forças de vida, o homem é assim chamado 
a tornar-se o ponto de equilíbrio onde poderão reunir-se, através dele, as diversas dimensões das quais é portador. Então ele merecerá verdadeiramente o nome de Maa, interlocutor de Maa-Ngala, e fiador do equilíbrio da criação. ${ }^{140}$

Como a perspectiva acima é encantada, não podemos ler a frase: "Mostre-me seu rosto, e eu lhe direi a maneira de ser de suas pessoas interiores" como uma licença para o que alguns lacanianos gostam de chamar pejorativamente de "interpretose" e a Neurolinguística chama de "leitura mental", ou seja, olhar a expressão de alguém e achar que sabe o que se passa em seu íntimo. O mau hábito de "ler" a expressão alheia é fruto de uma falta de educação - no sentido técnico - enquanto os Bambara referem-se a uma ciência que permite enxergar uma urdidura num rosto humano.

Viajante do Universo, portanto, atravessando todos os discursos, cada homem aparece a cada momento, em lugares diferentes e, desse modo, como disse Riobaldo "... não está terminado" pois "Nunca se acaba de conhecer Maa...", isto é, a todo momento essas pessoas são infindáveis, é no atual que o sujeito não termina, por isso, podemos transitar pelos outros, conectar com cada um em planos diferentes, "escolher" qual a dimensão que buscamos ver no outro.

Desse modo, não apenas buscamos outros lugares para nós mas também para os outros. A imaginação, aqui, é uma faculdade fundamental.

Entendimento misterioso, o "sujeito" é tanto o que se mistura e se conecta e se transmite quanto o que permanece um sem confundir-se num plasma de outros. Ele não possui identidade, pois é plástico, porém, é atravessado pela singularidade e, portanto, é único. Ao mesmo tempo, é único numa dimensão que não é a do indivíduo pois ele é único apenas perante uma totalidade na qual todos são um enquanto lugares do Um. A faculdade de julgar depende da capacidade de trânsito por essa totalidade, que é um atributo da imaginação.

Espacial por excelência, a imaginação é emancipação dos possíveis, ela preenche de aurora as tendas, os camelos e as miragens do real. A unidade encantada da vida não é uma unificação pela força ou pelo abstrato, é uma unidade no infinito e na transformação perene própria de cada homem que é "lugar de encontro de forças contraditórias em perpétuo movimento".

Dito de outro modo, o ego é um forjador de posições imaginárias que variam conforme o tempo, o lugar e os condicionamentos individuais e coletivos. É a posição que marca o vín-

\footnotetext{
140 Bâ, Amadou Hampâté, A noção de pessoa entre os fula e os bambara, Revista Thot, n. 64,1977 (texto originalmente editado em francês como capítulo do livro Aspects de la Civilization Africaine, Paris, Présence Africaine, 1972).
} 
culo a uma formação discursiva.

No filme "O Leitor", a protagonista, que atuou, na guerra, como membro do exército nazista, não é capaz de "retirar-se" com "um passo atrás" para observar, "de fora", as consequências de seu ato de manter trancada uma porta, impedindo cerca de 300 pessoas de escapar de um incêndio. De dentro da formação discursiva que a definia como "soldado a serviço", era "óbvio" que se ela abrisse a porta haveria "um caos". Assim como é "óbvio" que as judias sob sua guarda estavam destinadas a morrer, em algum momento, numa câmara de gás. Dar um passo atrás, descolar-se dessa formação discursiva que condicionava não apenas seus atos, mas, sua percepção e seu julgamento, não era algo que pudesse ocorrer-lhe. Como não é algo que ocorre, normalmente, em variadas circunstâncias, a muita gente. Felizmente, nem todo mundo encontra-se na posição de um soldado a serviço e armado.

Para a personagem, é natural cumprir seu dever sem que isso implique uma medida constante, disciplinada e técnica de avaliação e reflexão sobre seus atos, portanto, de descolamento de uma posição imaginária sustentada por uma formação discursiva, no caso, o nazismo e o extermínio imposto aos judeus. Ao contrário, uma certa idéia de lealdade pressupõe o "colamento" ao discurso.

Quando Hannah Arendt considerou que o crime nazista era contra a humanidade e não apenas contra os judeus, foi chamada de anti-semita. Quando alguém critica o governo brasileiro, por exemplo, não é chamado de anti-brasileiro, mas, quando alguém critica o governo de Israel, muitos judeus o consideram anti-semita. Não lhes ocorre, por um momento, buscar uma desidentificação com esta formação discursiva. Capturado numa formação discursiva e enclausurado numa posição imaginária, o ego constrói apenas os "outros" que possam corresponder ao seu desempenho de acordo com a "lei", isto é, com o discurso que the assegura uma identidade.

Hannah, a personagem do filme, não a filósofa, suicida-se após dizer que ela não era ninguém pois "the dead are still dead". Como o diabo, na história da velha, ela não pode desfazer o que fez. E ela não pode desfazê-lo porque o discurso legalista dos judeus do filme não lhe permite. "Não há o que aprender num campo de concentração", afirma a judia que a acusou. Esta é uma decisão de um ego capturado. Sempre há o que aprender quando é possível descolar-se do discurso em curso.

É possível, fora do contexto místico, aprender a produzir um descolamento do discurso, uma desidentificação técnica? Podemos ensinar nossas crianças a fazer isso sistematicamente, e não apenas eventualmente, desde pequenas? Podemos ensinar a pessoa a ser muitas pessoas? 


\subsection{YOU AND THE LAND ARE ONE - ACERCA DAS HISTÓRIAS DE ENSINAMENTO}

Descolar-se de um discurso, desapegar-se de uma posição imaginária, mudar de lugar, desidentificar-se da própria reatividade, podem ser modos contemporâneos de falar o que, mutatis mutandis, dizia-se com termos medievais como a "morte do ego" ou o "abandono do mundo".

Para o pensamento contemporâneo, não há propriamente a possibilidade de um descolamento, por assim dizer, absoluto do discurso: podemos, em certa medida, retirar-nos da captura de um discurso pela ação reflexiva e por uma autocrítica, porém, isso igualmente implica filiar-se a outro discurso porque não podemos conceber simplesmente algo fora ou além do discurso. Igualmente, mudar de lugar significa ir para outro lugar pois não podemos pensar o "não-lugar"141. Dito de outro modo, a Psicanálise poderá, sob certos aspectos, considerar que o "não-lugar" será feito de pura angústia ou, em outra perspectiva, que será foraclusão, contato com o Real sem a mediação da linguagem, isto é, psicose.

Para os sufis, uma longa série de novas questões abre-se aqui. Enquanto Thomas Mann concebe o seu contador de histórias como aquele cuja estrela é a lua, "... A senhora do caminho, errante que se move em estações uma após a outra, e transforma-se a si mesma depois de cada uma delas..." e como o que "dorme apenas em tendas, aguardando novas direções", Ibn 'Arabî vê desse modo tudo o que existe.

A existência tem sua origem no movimento. Não pode, portanto, haver imobilidade nela, pois se ela permanecesse imóvel, ela voltaria à sua origem que é o nada. A viagem nunca cessa, portanto, no mundo superior e inferior. Da mesma forma, as realidades divinas estão viajando sem cessar, indo e vindo, como a descida senhorial para o céu mais próximo ${ }^{142}$ ou o estabelecimento ascendente para

\footnotetext{
${ }^{141}$ Não se trata aqui, claramente, de utopia.

${ }^{142}$ Alusão a uma tradição da qual segue-se uma das versões: "Nosso Senhor - bendito e exaltado seja ele -
} 
o céu ${ }^{143}$, como convém à transcendência e à ausência de qualquer similitude ou semelhança. No mundo superior, as esferas conduzem em sua rotação perpétua, sem o menor repouso, os seres que elas contêm. Se elas se imobilizassem, a criação seria reduzida a um nada e a ordem do mundo chegaria ao seu cumprimento e ao seu fim. A evolução dos astros nas esferas é para estes uma viagem: "E a lua, Nós lhe determinamos as mansões" (Cor, 36:39).

Os movimentos dos quatro elementos, dos seres gerados a cada minuto, a mudança e as transformações geradas por cada sopro, a viagem dos pensamentos nas categorias do louvável e do reprovável, a viagem dos sopros emitidos por aquele que respira, a viagem dos olhares, despertos ou no sono, através das coisas vistas e sua passagem de um mundo a outro pela transposição de sua significação; tudo isso é sem nenhuma dúvida viagem para qualquer homem dotado de inteligência. Alguns consideram que o mundo dos corpos, desde o instante em que Deus o criou, não pára de descer em sua totalidade, no vazio sem fim ${ }^{144}$. Na realidade, não cessamos nunca de estar em viagem desde o instante de nossa concepção original e da constituição de nossos princípios físicos ${ }^{145}$, até o infinito. Quando aparece uma morada, tu te dizes: eis o termo; mas, a partir dela, abre-se uma outra via da qual tomas um viático para uma nova partida. Assim que percebes uma morada, te dizes: eis o meu termo. Mas, nem bem chegado, não tardas a sair para retomar a estrada. ${ }^{146}$

Assim como Rumi:

Sou o escravo de quem, a cada etapa, não imaginará que chegou ao final de sua meta. Muitas etapas hão de deixar-se atrás antes de que o viajante alcance seu destino. $^{147}$

Se o ego é identidade e identificação, o movimento é negação do ego, denarcisação. No entanto, como vimos, o ego também se "movimenta" e podemos ver o sujeito presente virtualmente em muitos níveis.

Como elemento de distinção, o desapego é fundamental: a agitação das cidades, a dispersão dos cidadãos, as viagens, físicas ou químicas, excitantes e excitatórias, a ênfase na ação - nos filmes, nos discursos políticos, nos ambientes empresariais - acompanhada da renitente certeza de que a ação reflexiva é um "desvio" ou um "atraso", a movimentação reativa dos homens, nada disso é desapego, portanto, não é movimento no sentido aqui

\footnotetext{
desce a cada noite para o céu mais próximo no último terço da noite e diz: quem me Invoca, para que Eu Ihe responda; quem Me pede, para que Eu Ihe dê; quem implora o Meu perdão, para que Eu o conceda? " (Buhâri, Sahîh tahajjud 14; II 63).

${ }^{\overline{14} 3}$ Cf. Corão 2:29: "Depois Ele estabeleceu-se, elevando-se para o céu e fez sete céus" cf. igualmente 41:11.

${ }^{144}$ No vazio em que Deus criou o mundo, cf. Futûhât II 150, cap. 78 sobre a $\underline{\underline{H}}$ alwa.

145 Usûl: deve-se compreender com este termo: os princípios de nossa constituição física, o calor, o frio, o seco, o úmido ou os da "manifestação informal", o intelecto, a alma, a matéria prima e a natureza.

${ }^{146}$ Ibn 'Arabî, Le dévoilement des effets du voyage, op. cit.

${ }^{147}$ Cit. por Idries Shah, in Perfumed Scorpion, op. cit., p. 13.
} 
vislumbrado.

O que é muito difícil de compreender, na perspectiva "ocidental contemporânea" é essa idéia de que o trabalho sobre si mesmo não é um trabalho individual. Merlin diz a Arthur, quando este Ihe pergunta o que significa ser rei: "Tu e a Terra são Um; se falhares, a Terra perece, conforme prosperares, a Terra florescerá"148.

A História não é pouco pródiga de reis que, na ignorância da dimensão simbólica das idéias acima, trataram a Terra como sua propriedade pessoal, não obstante, no Mundo Encantado, o rei e a terra são um.

"Coração selvagem" (Brave Heart) é o nome de um filme hollywoodiano com Mel Gibson que ganhou vários Oscares na Academia. "Robin Hood", "estrelado" por Kevin Costner, também veio de lá. Ambos são paradigmáticos da idéia de "liderança" professada nas empresas do mundo atual e considerada um dos grandes pilares da "educação voltada para o futuro" - como se sabe, a boa escola é "a que forma líderes". Líderes como as personagens de Mel Gibson e Kevin Costner, que conclamam os seus liderados a lutar contra o que os oprime em nome da liberdade. A grande palavra de ordem: "freedom". Evidentemente, nenhum consultor empresarial, ao mostrar esses filmes em seus cursos sobre liderança, está propondo aos clientes que os escutam - diretores e gerentes - que lutem contra os governos autoritários e a classe hegemônica opressora pois isso, como se "vê" nos filmes, "corresponde ao passado", "àquele tempo em que não havia democracias". Hoje, graças ao "espírito de liberdade" de grandes líderes do passado glorioso da América ou da Europa, conquistamos o estágio "mais avançado" do progresso que é a democracia. Portanto, o que é importante nesses filmes é que o líder é aquele que sabe "falar aos seus liderados", sabe "motivá-los" e sabe "fazer com que eles superem suas fraquezas e dêem o máximo de si". Como qualquer herói moderno que se preze, o líder está disposto aos sacrifícios necessários ao bem comum e suas virtudes são superiores às do homem comum. Tudo isso porque, acima de tudo, ele preza o ideal supremo do liberalismo e do neoliberalismo, a liberdade de ação.

Nessa perspectiva, o agir "em nome de Deus", professado pelos "terroristas islâmicos" ou pelos "crentes" de qualquer religião, é, por um lado, monstruoso, por outro, pueril, por outro, puritano, por outro, soberba, por outro, estreiteza. A liberdade de agir, ao contrário, como elogio do individual, do direito, do livre comércio e do livre arbítrio, é um bem "republicano" por excelência.

Em uma passagem da peça "Henrique V", de Shakespeare, o rei parece encontrar-se na mesma situação dos heróis acima: seus homens, em campanha na França, estão cansados e famintos, o exército francês, em maior número, marcha sobre eles, tudo leva a crer que não há esperança. Alguns querem fugir. Henrique faz um discurso inspirado e, ao final, os franceses são derrotados. Aparentemente, o grande líder, mais uma vez, fez com que seus

${ }^{148}$ No filme Excalibur, de John Boorman. A citação em inglês é: "You and the land are one, if you fail, the land will perish, as you thrive, the land will blossom". 
liderados se superassem. No entanto, Shakespeare, como Cervantes, ainda pertence a um mundo encantado. Eis o discurso de Henry, the 5th:

Se estamos destinados a morrer, esta é uma perda suficiente para nosso país, e, se tivermos que viver, quanto menos formos, maior será a glória de cada um. Se é a vontade de Deus, não desejes mais nenhum homem. Proclama, entre minhas hostes, que aquele que não tem estômago para lutar pode retirar-se. Seu passaporte lhe será dado e algum dinheiro para a viagem. Não queremos morrer perto de quem tem medo de morrer ao nosso lado. O dia de hoje é a festa de São Crispiniano. Quem sobreviver a este dia e voltar a salvo para casa, ficará na ponta dos pés ao ouvir falar deste dia. E o nome de Crispiniano o despertará. Aquele que vir este dia e chegar à velhice, anualmente, na vigília dessa festa, dirá aos vizinhos: "Amanhã é dia de São Crispiniano". Então, ele erguerá a manga e mostrará as cicatrizes. E dirá: "Estas feridas, eu as recebi no dia de São Crispiniano". Homens velhos esquecem, mas aquele que tudo tiver esquecido, irá lembrar-se de suas proezas naquele dia. E nossos nomes serão familiares para ele: Harry, o rei, Bedford, Exeter, Warwick, Talbot, Salisbury e Glocester serão vivamente lembrados com taças espumantes. O bom homem ensinará esta história a seu filho. $E$ a festa de São Crispiniano será, de hoje até o fim dos tempos, associada à nossa lembrança. Nós poucos, nós, felizes poucos, nós, bando de irmãos, pois aquele que, hoje, derramar seu sangue comigo se tornará meu irmão, e por mais vil que seja, este dia o tornará um nobre. E os que ficaram na Inglaterra deitados, amaldiçoarse-ão por não terem estado aqui, e menosprezarão sua nobreza ao ouvir falar de alguém que lutou conosco no dia de São Crispiniano. ${ }^{149}$

O que este "líder" propõe aos seus "liderados" é, em primeiro lugar, a morte, em segundo, para aqueles que sobreviverem, a memória, marcada por um tempo simbólico. O discurso deste rei não é uma incitação, nem um convencimento, nem um processo de motivação. Harry não fala à razão, nem à emoção. Sua fala consiste numa marca, numa operação simbólica tornada possível pela autoridade do rei. O termo "autoridade" tem, no contexto, um significado específico.

Daquele dia em diante, "to the ending of the world" ("...até o fim dos tempos"), a data passa a ter um significado próprio e a sua lembrança possui um caráter técnico. Foi o rei quem instituiu este significado, foi ele quem marcou aquela luta e a associou ao santo daquele dia e "encomendou" a data aos tempos futuros.

Isso é diferente, muito diferente, de uma data comemorativa. Podemos lembrar, todo ano, a data em que morreu Martin Luther King, o dia da Independência do país, podemos marcar datas com a intenção política de evitar o esquecimento de alguma atrocidade como, por exemplo, o nazismo. São formas mnemônicas cujo efeito a ser buscado é a lembrança de um acontecimento. Não são formas simbólicas no sentido com que o termo é

${ }^{149}$ Shakespeare, The Illustrated Stratford Shakespeare, op. cit., p. 460. 
tratado aqui.

Marcar com um significado quer dizer forjar uma realidade. A repetição encantatória da expressão "Saint Crispin's day" é, entre outros, um dos veículos desta forja. Se, em termos encantados, dizer é ser, ao dizer o que disse, o rei forjou um lugar a ser ocupado pelos soldados, criou um conjunto significativo, abriu um campo possível. Não se trata de uma relação de causa e efeito. Por ser rei, isto é, por ter as prerrogativas da centralidade, o rei pode falar de um lugar inaugural. O efeito simbólico não é a motivação das pessoas, é a criação de um valor significativo perene: tornado simbólico, este dia "shall gentle his condition" ("este dia o tornará um nobre"), tornará o vil nobre. A operação alquímica real vivida por aqueles homens irá fornecer o substrato simbólico para que este dia passe a ter o poder de operar uma transformação análoga naquele que celebrá-lo no futuro. A partir desta marca, este dia passará a ser veículo de uma transmissão.

Nos anos seguintes, os sobreviventes da batalha, ao ouvir a menção deste dia, entrarão em contato novamente com essa fonte alquímica e, pela lembrança de seus feitos, atravessarão novamente o mesmo processo de purificação. O rei ungiu o dia e a batalha nele travada. Se não houvesse rei, isso não seria possível. Rei encantado, bem entendido. Nessa perspectiva, ganhar a batalha não é o resultado mais importante, uma derrota também teria o seu valor específico. O discurso visava a experiência - simbólica, não subjetiva, não emocional - mais que a vitória.

Em viagem à Turquia, tive a oportunidade de conversar com alguns membros de uma ordem sufi. Dentre outras explicações, contaram-me que uma tekkia, a sala em formato octogonal em que realizam seus rituais, necessita ser "ativada" pelo mestre da ordem. Naquela ordem, o procedimento de ativação consistiu basicamente numa fala do mestre diante dos discípulos colocados em círculos dentro do pequeno edifício de oito paredes. Nessa fala, o mestre, depois de declarar sua filiação a uma cadeia de transmissão (silsillah), "entregou" o local aos discípulos. Um dos membros que mais trabalhou na construção da tekkia, tendo inclusive passado a noite anterior à ativação realizando os últimos preparativos para a cerimônia, relatou-me que, algumas horas depois de terminada a ativação, entrou novamente na sala para meditar e viu-se, completamente surpreso, num lugar no qual ele nunca antes havia estado. O mestre havia marcado a sala e determinado que ela se tornasse outro lugar, exatamente como, na peça de Shakespeare, Henrique $V$ fez com o dia e o espaço da batalha.

Quando Abrahão recebeu dos céus a ordem de construir a Casa de Deus em forma de cubo ( $\left.k a^{\prime} a b a\right)$ e ali abrigar a pedra negra, ou quando Muhammad destruiu os ídolos que haviam tomado esta Casa, reinstalando ali o culto ao Deus único, tratava-se de operações análogas.

De um ponto de vista técnico, há que se considerar que tais operações simbólicas não são perenes. Não fosse assim e Muhammad não teria sido obrigado a "revivificar" a Ka'aba que, em seu tempo, já havia perdido toda a sua potência simbólica. Os símbolos perecem 
pois, como tudo, são vivos. Basicamente, perecer significa que deixam de pertencer a uma cadeia de transmissão. Periodicamente, no entanto, alguns, por razões diversas, são "revificados". Assim foi com Joana D'Arc, como se pode ler no belo artigo de Michel Valsân ${ }^{150}$ e, num âmbito mais restrito, com Abd el-Qadir, o Emir da Argélia que lutou contra a invasão francesa no séc. XIX e, paralelamente, foi o protagonista de uma "revificação" da silsillah akbari, a cadeia de transmissão do ensinamento de Ibn 'Arabî ${ }^{151}$.

Ao mesmo tempo, há, no Mundo Encantado, coisas que aconteceram na História e coisas que aconteceram somente nas histórias. O Henrique $V$ da História dificilmente terá possuído a estatura espiritual da personagem shakespeariana.

Nos dias de hoje, evidentemente, não temos mais a possibilidade de que alguma figura pública possua o conhecimento e a autoridade (simbólica) para produzir tais operações. Esta possibilidade do Encantamento, salvo em confrarias secretas, está fechada, o que é uma outra maneira de, por um lado, "definir" o Encantamento e, por outro, dizer que a maioria destes antigos símbolos perdeu sua baraka ${ }^{152}$ e não possui mais qualquer valor de ordem simbólica.

No entanto, guardadas as devidas proporções, há analogias que podem ser construídas de acordo com os nossos modelos mentais e que guardam aspectos de ressonância com esta ciência. Refiro-me aqui, particularmente, a dois aspectos: 1) a idéia de centralidade; 2) os contos de ensinamento; dos quais trataremos a seguir. Antes, porém, é necessário apreender, tanto quanto possível, algo mais da estruturalidade dessas operações.

Ao saber que venceram a batalha, o rei proclama que deve ser enforcado aquele que se gabar da vitória e "tirar o louvor de Deus, a quem ela de fato pertence". O processo de denarcisação está completo. Ninguém recebe uma recompensa, portanto, uma significação particular por seus atos. Não há mérito próprio porque as ações foram guindadas a uma condição de outra ordem e o rei propos a seus homens que "morressem antes de morrer"153.

Essa idéia, pensada num contexto desencantado, traduz essa perspectiva rígida daqueles que não podem experimentar uma das grandes alegrias desta vida que é a de sentir-se grande pela grandeza de seus atos. Em vez disso devem manter o semblant de um sentimento hipócrita de falsa humildade. Mas em termos encantados, o júbilo em questão é o de poder guindar os atos à condição de louvor a Deus, o que corresponde a um alargamento do ser: tornar-se capaz de Deus por meio do ato singular.

\footnotetext{
${ }^{150}$ Remarques Occasionnelles sur Jeanne D'Arc et Charles VII, in Études Traditionnelles, nos. 412-413.

${ }^{151}$ Ver a respeito a introdução de Michel Chodkiewicz in Écrits Spirituels, op. cit.

152 Baraka, no árabe, berakhah ou bracha, no hebraico, bênção, em português, o termo corresponde a uma designação genérica cuja tradução aproximada pode ser "energia espiritual". De modo semelhante a vários outros termos aqui utilizados (intuição, alma, ego, verdade, etc.), a idéia encerra uma multiciplicidade de distinções internas; assim, há, na realidade, vários tipos de "energia espiritual" e de transmissão da mesma. ${ }^{153}$ Alusão a um hadit. Ver nota 30.
} 
Nas histórias encantadas, o reino é um único organismo no qual o rei corresponde a uma função assim como os súditos a outra. Não havendo indivíduos separados, trata-se de um conjunto que deve funcionar harmonicamente. Evidentemente, não há de ser possível encontrar na História um reino que tenha de fato conhecido o tipo de harmonia a que me refiro e deve-se ter em mente que não é disso que se trata. No Encantamento, no entanto, se o reino está em desarmonia, é porque houve alguma maldição, ou então, o rei está agindo mal, ou, enfim, por qualquer outra razão. O que importa é que a harmonia deve restabelecer-se sob pena de que a história não tenha um final feliz. Acostumados, porém, como estamos, às instituições nascidas sob a égide de um culto à hegemonia de um grupo particular que, detentor do poder, utiliza-o para determinar que a vida de todos os seus membros tenha o significado que melhor lhe aprouver, difícil é para nós supor um reino cujos súditos não estejam obrigados a participar como figurantes de um grotesco espetáculo de elogio a um rei ou a um sistema de poder.

Em outra passagem da mesma peça, Shakespeare nos faz ver que o fato de não haver indivíduos não significa que não há autonomia: "Cada súdito deve obediência ao rei, mas cada súdito é dono de sua própria alma", diz o rei.

"Ele os criou de uma alma única", informa-nos o Corão (39:06). Não se trata de um coletivo nem de uma corporação. Não se trata de uma construção jurídica, muito menos de um pacto social, tal como compreendemos a expressão atualmente. O corpo da terra é percebido como análogo ao corpo do rei e ao corpo de cada um. A experiência de totalidade e de autonomia do corpo é transposta para a terra e vice-versa. Desse modo, não fossem os soldados a lutar na batalha, o rei, por mais ciência que tivesse, não poderia realizar nenhuma operação simbólica.

Na África do Sul, os processos de julgamento sob a presidência de Nelson Mandela, logo após o fim do apartheid, utilizaram um "conceito" tradicional tribal: o ubuntu. Nesses processos, os que foram acusados por crimes de tortura e morte poderiam pedir anistia desde que confessassem seus crimes diante de suas vítimas. Por assumirem a verdade de seus atos, colocavam-se em condição de ser perdoados, pois, segundo a perspectiva do ubuntu, "aquele que faz um mal a um homem, o faz a todos os homens e principalmente a si próprio" e, pela mesma via, aquele que faz um bem, no caso, por meio do perdão, o faz igualmente a toda a humanidade. Os julgamentos foram feitos, portanto, incorporando a justiça da Tradição negra e não apenas a partir do direito "branco" ocidental. Dizer a verdade, torná-la pública, trazia, evocava, inaugurava a condição simbólica para o perdão. Isto não é coisa facilmente explicável para nós. Eu não diria que a Psicanálise pode dar conta desta questão pois não se trata da fala de um sujeito. O ponto crucial é que, como os Bambaras, estes homens sabem que "tudo está interconectado". Assim como o afirma o Talmud:

Por esta razão foi o homem criado em separado, para ensinar que quem destrói uma única alma (...) a Escritura o imputa como se ele tivesse destruído o mundo todo, e aquele que preserva uma única alma (...), a Escritura concede-Ihe mérito 
como se ele tivesse preservado o mundo todo. ${ }^{154}$

Alerto o leitor para o que, no meu entendimento, seria um equívoco: pensar estas colocações como tendo por trás "uma necessidade de pertencimento", esta que vários antropólogos pretendem ver em grupos indígenas. Não se trata de psicologia moderna. Tampouco se trata da identificação com um discurso hegemônico: isso seria puro reducionismo. Prossigamos com o tema das histórias de ensinamento.

No tempo em que as escolas estavam destinadas a vigiar e punir, muitas das histórias contadas às crianças possuíam uma intenção formadora: do caráter, da moral, dos valores, da consciência dos deveres, etc. Sabemos, é claro, que, desde sempre, houve histórias elaboradas como um meio de disseminação dos chamados discursos hegemônicos. Sabemos que a formação de um determinado tipo de consciência é fundamental para garantir a unidade de um grupo e de um sistema de poder. Acrescento, no entanto, que ver nos mitos, nos contos tradicionais, numa palavra, na literatura encantada de um modo geral apenas um propósito "formador" é um procedimento etnocêntrico. Do mesmo modo que a palavra sempre foi usada para construir e manter estruturas de dominação, a palavra também sempre foi usada para combatê-las. O Encantamento, por motivos óbvios, corresponde a esta segunda perspectiva ${ }^{155}$.

No Mundo Encantado, os contos de ensinamento constituem material técnico no Sufismo. Como tudo no Sufismo, os contos de ensinamento visam o Conhecimento.

Antes de mais nada, é preciso lembrar que os contos a que me refiro nunca foram exclusividade de crianças. Nas rodas indígenas, nos vilarejos, nas tribos, nos mosteiros e nos caravanserais, homens e mulheres de qualquer idade formaram grupos de ouvintes muito atentos aos mínimos gestos dos contadores de histórias que, noite e dia, transmitiram a baraka ao longo dos séculos.

Hussein ${ }^{156}$ havia buscado pelo mundo todo um mestre que deveria transmitir sua mensagem através de todas as gerações e não o havia encontrado. Já sem esperanças, ouviu uma grande comoção ao passar por um beco. O diabo estava repreendendo a um de seus discípulos por contar piadas.

\footnotetext{
154 Talmud, Sanhedrin 37a.

155 O leitor poderá objetar que uma distinção de tal modo categórica pretende fazer crer que haveria uma pureza a ser reputada aos místicos que os tornaria imunes às tentações do poder, o que sugere, minimamente, uma mistificação. Recordo, então, que, no capítulo 1.2, procurei "descolar" o Encantamento da História justamente para evitar esse tipo de confusão. É evidente que não há na Mística uma homogeneidade tal que possamos supor que, no instante mesmo em que um indivíduo qualquer torna-se "um místico", significa que ele passa a estar acima das vicissitudes. Se nosso assunto fosse, por exemplo, o teatro, o fato de afirmarmos qualquer coisa sobre a natureza desta arte não significa que estamos dizendo que todos os que ali atuam são excelentes atores. O que não impede que haja, de fato, excelentes atores, assim como há de haver, de fato, santos cuja pureza não pode ser sequer vislumbrada a partir de uma perspectiva desencantada.

${ }^{156}$ Neto do Profeta Muhammad.
} 
-- Nasrudin! - vociferou o Velho Vilão - Por tua atitude irreverente, condeno-te ao ridículo universal. No futuro, quando alguém contar uma de tuas histórias, mais outras seis serão contadas sem interrupção, até que se torne evidente que és uma personagem grotesca.

Hussein, que escutava furtivamente, compreendeu que cada situação dá origem a seu próprio remédio, e que este era o modo de apresentar em sua verdadeira perspectiva os males do Velho Vilão. Chamou Nasrudin em um sonho e impartiuIhe uma porção de sua baraka, o poder sufi que penetra nas significações. Como resultado, todas as histórias sobre Nasrudin converteram-se em obras "independentes". Podiam ser interpretadas como piadas, tinham um significado metafísico, eram infinitamente complexas e compartilhavam a natureza de consumação e perfeição que havia sido roubada da consciência humana devido às artes corruptoras do Velho Vilão. (...) De modo que, por meio deste método, os ensinamentos de Nasrudin, inspirados por Hussein, ficaram gravados para sempre num veículo que não podia ser totalmente destruído (...). ${ }^{157}$

No Anexo 2, o leitor encontrará Contos da Tradição Oral de diversos locais e épocas bem como sete histórias de Nasrudin.

Como tudo no Sufismo, os contos de ensinamento são, antes de qualquer coisa, citações do Corão. São, portanto, aspectos da Revelação. Constituem, conforme a metáfora pensada pelos sufis para aludir ao Livro, urdiduras nas quais viscejam múltiplas tramas.

Os padrões geométricos aos quais me referi acima (cap. 2.1) mostram-se agora com um pouco mais de detalhe. Na arte islâmica, um mesmo padrão pode ser a urdidura de infindáveis tramas.
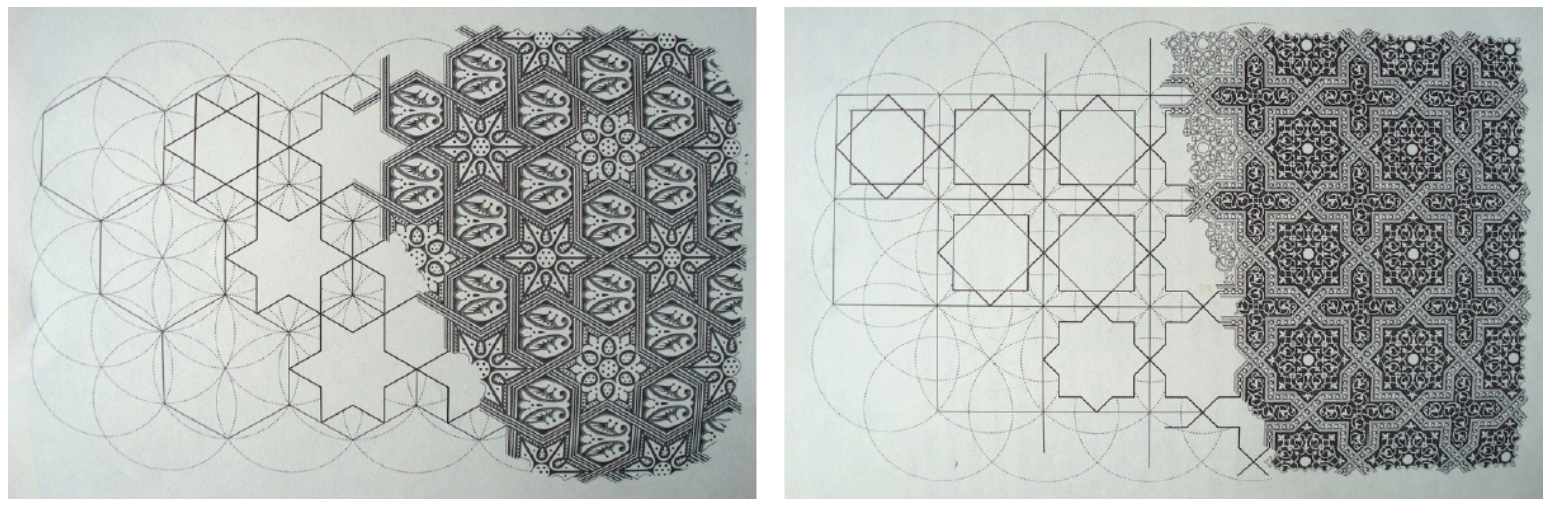

O estudo desses padrões não se reduz, com toda a evidência, ao estudo da geometria tal como a concebemos no ensino fundamental, tanto das escolas brasileiras quanto da maior parte da escolas do mundo atual. Ele compreende, como nos mostra Sylvia Leite, o conhe-

${ }^{157}$ Idries Shah, Los Sufies, op. cit., p. 83-4. 
cimento de toda a perspectiva simbólica que subjaz a esta arte-ciência.

A falta de um contato mais direto com os aspectos místicos dessa linguagem talvez seja a razão pela qual alguns historiadores tenham reduzido a iconoclastia do Islam a uma simples proibição religiosa que teria empobrecido sua arte e levado seus artistas a adotar a geometria como única solução possível. O simbolismo nos mostra (...) que tanto a iconoclastia como o uso das figuras geométricas resultam não de uma simples negação de imagens, mas da afirmação de princípios filosóficos e iniciáticos.

Como representar essa rede flexível e complexa, que ganha estabilidade e harmonia unicamente pela simetria das relações, usando imagens definidas e imutáveis? Para os sufis, essa seria uma tarefa tão impossível quanto provavelmente indesejável. (...) Definir, como já diziam os pitagóricos, é dizer o que pertence e o que não pertence a uma forma. Assim, quanto menos se define, menos se exclui. $^{158}$

A hipótese da pobreza é desfeita pelo leque incalculável de símbolos e analogias que residem em seus traçados e que os impregnam de riqueza e complexidade. $A$ suposição de imobilidade também perde todo o seu sentido ao constatarmos que os padrões geométricos da arte islâmica se expressam, simultaneamente, no tempo e no espaço, na medida em que o olhar do espectador é levado a acompanhar suas repetições rítmicas. Sucumbe, igualmente, diante da enorme flexibilidade, ou mobilidade, dos traçados geométricos, que se apresentam sob diferentes coloridos e versões (...)

Ao estudarmos a arte islâmica do ponto de vista simbólico, que é o de seus autores, é possível encontrar a chave para a compreensão do universo místico em que eles viveram (...)

Apesar deste trabalho ter-se limitado a comparar os padrões geométricos à língua árabe e aos quadrados mágicos, seguramente isso poderá ser feito com um número incontável de linguagens, entre elas a Música, a Medicina, os elementos químicos e o universo celular, como ficou sugerido em alguns pontos do texto, o que só vem reafirmar a riqueza e o movimento interno dos padrões e de sua rede de símbolos e analogias. ${ }^{159}$

O leitor não deve deixar-se despistar pelo uso do termo "simbolismo" ligado às artes encantadas. Dizer que uma obra afirma "princípios filosóficos e iniciáticos" é dizer que uma determinada linguagem, digamos, artística, traduz linguagens "celestes", isto é, realidades da ordem do invisível, seja este sutil ou espiritual. Isto não é o mesmo que dizer que o conhecimento de um simbolismo revela que tal símbolo quer dizer tal coisa. Dizer que, numa história, o rei simboliza a generosidade e a princesa a delicadeza é apequenar o Encantamento. Para sermos devidamente rigorosos, é preciso, em primeiro lugar, lembrar que, nos termos de Ibn 'Arabî, um símbolo sempre simboliza - isto é, evidencia e oculta ao mesmo tempo - um Nome de Deus. Em segundo lugar, que cada Nome de Deus é uma

\footnotetext{
${ }^{158}$ Leite, O Simbolismo dos Padrões Geométricos da Arte Islâmica, op. cit., p. 33-4.

${ }^{159}$ Idem, ibidem, p. 173-4.
} 
realidade inesgotável, portanto, um símbolo sempre simboliza "a cada dia uma nova obra", uma nova realidade. Nem a arte nem o mundo são ilustrações da Verdade, eles são a Verdade mesma, portanto, não há pouso fixo para o simbólico.

A idéia de Revelação combina tanto o caráter fixo e imutável da letra (lâ tabdîla fî kalimâti Llâh, "As Palavras de Deus não mudam", Cor, 10:64) quanto a inesgotabilidade de suas possibilidades de significação ("Se todas as árvores da terra se tornassem cálamos, se o mar se tornasse tinta e fosse aumentado de sete outros mares, ainda assim a Palavra de Deus não se esgotaria", Corão, 31:27)

A artista plástica Cássia Castro trabalha com tramas e urdiduras em suas pinturas, a partir de padrões geométricos islâmicos medievais. Trata-se de uma pesquisa contemporânea, fora do contexto islâmico e histórico dos padrões da Alhambra ou de uma mesquita em Bohara. Tomo emprestado seu trabalho para abrir uma perspectiva atual em minhas considerações.

"In the last few years, studying art in other cultures, I was led to the Medieval geometric patterns. Those

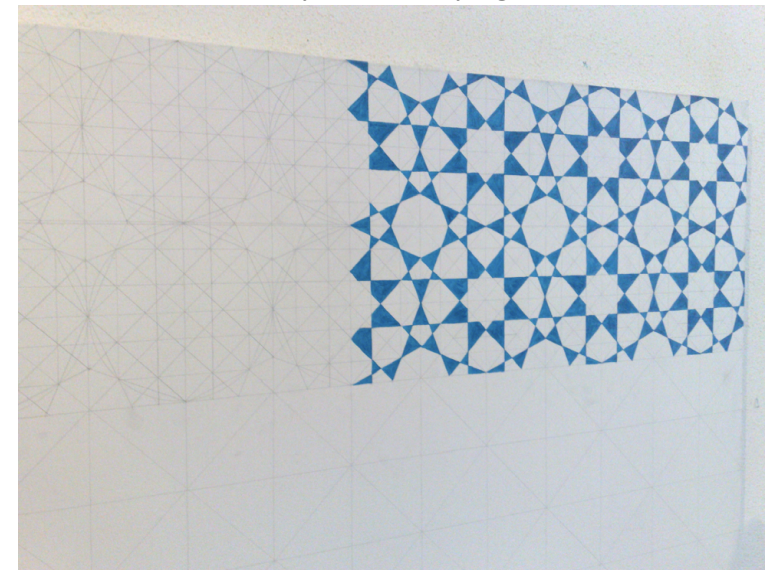
patterns explore the relationship between unity and multiplicity. The designs (warp) show the everchanging colors and forms that come from a same structure (weft), so the same weft can produce uncountable warps.

My aim is, through the combination of patterns and colors, warps
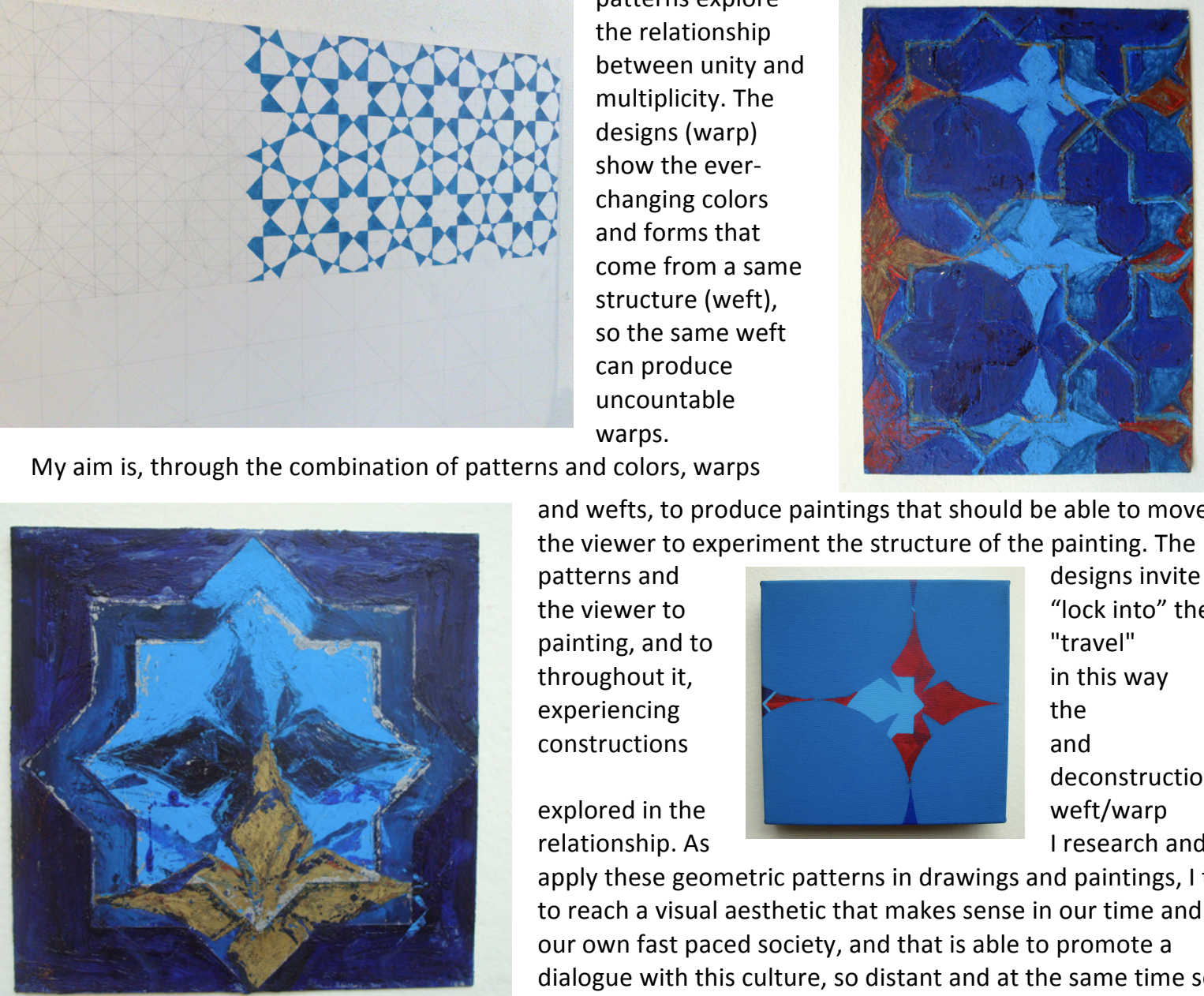
and wefts, to produce paintings that should be able to move the viewer to experiment the structure of the painting. The patterns and the viewer to painting, and to throughout it, experiencing constructions

explored in the relationship. As

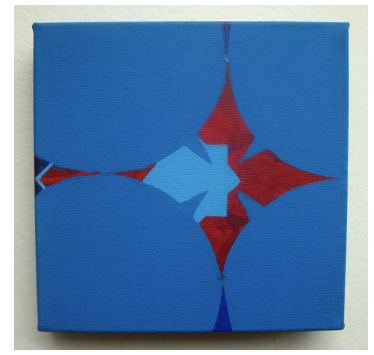
designs invite "lock into" the "travel" in this way the and deconstructions weft/warp I research and apply these geometric patterns in drawings and paintings, I try to reach a visual aesthetic that makes sense in our time and our own fast paced society, and that is able to promote a dialogue with this culture, so distant and at the same time so close to us." (Cássia Castro) 
O acoplamento, tal como afirmei no cap. 2.2, consiste numa relação integral com a arte, no caso, visual, na qual o contemplador se deixa, sob certos aspectos, penetrar pela obra e organizar-se por ela, de modo a tornar-se semelhante a ela e participar de sua riqueza harmônica. Sob outros, envolve-se num processo de percolação no qual obra e contemplador filtram-se mutuamente e extraem-se um do outro seus ensinamentos. A relação é, portanto, tanto de entrega quanto de proposta, de surpresa quanto de indagação.

O mesmo se dá no caso de artes não visuais. A recitação do Corão, por exemplo, é, igualmente o contato reiterado com urdiduras e tramas em seus formatos variantes, como a repetição de Nomes de Deus (dikr). Do mesmo modo, ouvir ou ler uma história encantada.

A rigor, todo texto escrito pela pena de um mestre sufi, tenha ele a forma de uma epístola, de um tratado ou mesmo de um conto de ensinamento, consiste numa ponte entre o leitor e o Corão ${ }^{160}$.

"Perguntaram ao sayed [Sayed Sabir Ali-Shah]: por que o Shay $\underline{\underline{h}}$ Attar escreveu $O$ memorial dos amigos de Deus?

- Porque o Corão já não era mais vivido e sim explicado, respondeu ele."161

Como urdidura, cada conto é um trabalho dentro de uma totalidade. Como um conjunto de padrões geométricos, que organizam "em camadas" o contemplador-passageirocaminhante de uma rua em Sevilha ou Córdoba, o conto também é um lugar de acoplamento. É preciso relacionar-se com a sua totalidade, fazer o seu taclid (imitação).

Nessa perspectiva, a relação com a Revelação é o "modelo excelente" da relação do homem com qualquer outra coisa. Como vimos, todas as coisas são sinais de Deus e celebram o seu louvor, mas este louvor não é um solilóquio, há respostas de Deus em diversos níveis pois "...a cada dia, Ele se ocupa de uma [nova] obra." (Cor, 55:29). No entanto, a questão de suprema importância e somente presente, com essa radicalidade, na Mística, é que Deus responde a cada um em sua singularidade.

O modelo excelente da relação com a Revelação é a singularidade. Relacionar-se com qualquer coisa como se ela fosse uma Revelação é relacionar-se com ela a partir de um lugar singular. Assim, as histórias de ensinamento possuem o seu próprio modo de louvor a Deus e esse modo é dirigir-se a cada ouvinte em sua singularidade.

Nesse caminho, é preciso acrescentar que as "pessoas da pessoa" são múltiplas e também encontram-se organizadas segundo linguagens, portanto, segundo estruturas verticais e horizontais, como veremos adiante. $O$ conto dirige-se a todas as pessoas da pessoa. Ao ego (e suas "camadas") e ao coração (e suas "faces").

\footnotetext{
${ }^{160}$ Para um estudo mais aprofundado da questão, remetemos o leitor ao clássico "Un Océan sans rivage", de Michel Chodkiewicz, op. cit. (em inglês, Un Ocean without shore).

${ }^{161}$ Idries Shah, Sages d'Orient, op. cit., p. 53.
} 
Infelizmente, um número considerável de professores orienta-se para levar seus alunos a "compreender" um conto, a analisá-lo, a perceber as idéias presentes, o encadeamento da narrativa e as lições que podem ser aprendidas com a "experiência alheia". Como se apenas o conteúdo manifesto fosse integralmente o conto. Como se a experiência em questão pudesse ter algo de "alheia". Num conto relatado por Idries Shah, temos a sutil referência:

(...) consideram sempre que as fábulas aludem, na realidade, a outros, não a si mesmos. $^{162}$

E, trabalhando com contos sufis, Regina Machado sintetiza essa perspectiva:

Assim, além do simples entretenimento, das abordagens psicológicas, antropológicas ou filosóficas, uma história pode conter outros níveis de funcionamento efetivo que só serão percebidos ou examinados quando uma certa informação fundamental se tenha operado em nosso espírito. O estudo intelectual do simbolismo seria, então, apenas um dos níveis de compreensão desse material, e não a via mais efetiva de aproximação de seu conteúdo mais profundo. Para tanto, fazse necessário um deslocamento de atenção, do conto para o sujeito que busca apreendê-lo, isto é, deixar de procurar algo que está oculto no conto enquanto forma objetiva, continente em si mesmo de um conhecimento a ser decifrado, por qualquer meio que seja. Em vez disso, é preciso desenvolver uma qualidade interior para compreender que a significação não está lá, no conto, mas na forma como este atua sobre nossa percepção.

Parece que essa perspectiva aberta por Idries Shah oferece uma possibilidade de nos aproximarmos dos contos como crianças curiosas que se deixam conduzir pelo fio da narrativa, atentas ao efeito que nelas se produz a cada acontecimento relatado. À medida que nos deixamos tocar e despertar para outros tipos de entendimento, nossa percepção se modifica, numa experiência em que nos perguntamos o que cada história nos diz naquele momento específico de nossa contingência pessoal. Como no conto chinês em que o mestre carpinteiro interroga a árvore que encontrou na floresta, à espera de transformar-se em sua mesa: "O que você tem para mim e o que eu tenho para você?". ${ }^{163}$

Exatamente como na relação com a Revelação, a escuta meditativa da narrativa de uma história é uma escuta de si mesmo, na qual o fiel entra em contato com a resposta de Deus ao seu próprio secreto louvor. Trata-se, segundo uma das 11 regras da ordem Naqshbandi ${ }^{164}$, de uma viagem à terra natal (safar dar watan), numa palavra, de autoconhecimento.

Dentre os inúmeros termos que podem facilmente gerar confusões e malentendidos por

\footnotetext{
162 Idries Shah, Monasterio, op. cit., p. 112.

163 Regina Machado, Acordais, op. cit., pp. 170-1.

${ }^{164}$ Nome de uma das mais importantes ordens sufis.
} 
terem assumido hoje conotações muito diversas, o autoconhecimento é certamente um dos que se encontram em pior situação.

Para o senso comum atual, conhecer a si mesmo quer dizer, antes de mais nada, conhecer-se como indivíduo, esta entidade que, tantas vezes padecendo da falta de um suporte simbólico, é abstrata pois concebida como "coisa em si". Quer também dizer conhecer suas qualidades, seus defeitos, sua personalidade e toda a série de atributos "fixos" e "distintivos" de cada um em relação aos outros.

No Mundo Encantado, o autoconhecimento é, em seu aspecto mais sutil, o conhecimento daquilo a que se aspira. Como vimos:

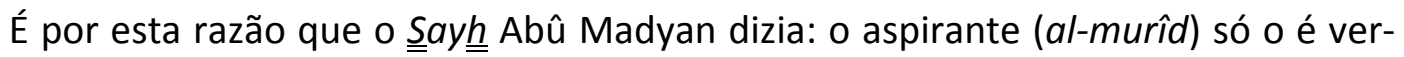
dadeiramente quando encontra no Corão tudo aquilo a que aspira. Qualquer palavra que não possua esta plenitude não é realmente Corão. ${ }^{165}$

Aquilo a que se aspira ou "o desejo de seu coração", como vemos na história do Cavalo Mágico ${ }^{166}$, consiste, ao mesmo tempo, numa aspiração que é uma "para a vida" e uma para cada situação. Trata-se de estar em contato com o seu próprio modo de atuar e de responder à "realidade", modo esse que, do ponto de vista do coração, é sempre diferente.

Trata-se também de um trabalho de construção das aspirações, de criação de marcas sobre a "realidade", de obras que sinalizam a passagem da caravana no deserto e que servem de sinais a outras caravanas. O conhecimento, vale insistir, não é, como nosso hábito mental nos faz frequentemente crer, o conhecimento de algo que está pronto.

Num aspecto mais denso, trata-se da observação técnica do ego e suas construções imaginárias, seus imensos edifícios de conjeturas e abstrações sobre as coisas e as situações, sua busca de segurança e permanência, as posições imaginárias nas quais suas paixões o encastelam, qual princesa roubada por jinns ${ }^{167}$, qual vilarejo assombrado por dragões.

Trata-se do combate espiritual realizado pela alma autoacusadora, pelo combatente viril (al-rijâl) diante dos versos corânicos que apontam a falsidade e a hipocrisia dos inimigos infiéis. Pois, como vimos ${ }^{168}$, o Corão nos incita a combater "o inimigo mais próximo" (Cor, 9:123), e o inimigo mais próximo, como nos lembra Ibn 'Arabî, é o nosso próprio ego.

Nesse aspecto, ouvir o conto, como ouvir a recitação corânica, é entrar em contato com a vileza, com o hipócrita infiel de cada um. No entanto, é preciso muito cuidado. Não se trata de um processo de identificação "do lado sombrio" de cada um. Não se trata de identificação de modo algum. Ao contrário, a busca é a da desidentificação.

\footnotetext{
${ }^{165}$ Ibn 'Arabî, cit. e trad. por Chodkiewicz, in Océan, p 46.

${ }^{166}$ Ver Anexo 2.

${ }^{167} \mathrm{Na}$ tradução usual, gênios.

${ }^{168}$ Na página 102 do presente trabalho.
} 
Nesse sentido, é fundamental compreender que o processo não consiste em "olhar para dentro de si mesmo". Este é um equívoco cometido até pelo ex-presidente do Irã, alHatami, ao afirmar:

"Em vez de desafiar a amarga realidade política vigente e buscar uma maneira de mudá-la, oferecendo realidades e visões alternativas, o sufismo, ao menos em suas versões mais extremadas, resistiu à ordem política dominante negando a relevância conjunta da política e do pensamento político. Como disse al-Farabi, nessa seara, muitos místicos pregaram a teoria de que a compreensão e a salvação reais só poderiam advir pela negação de todos os bens terrenos, incluindo a sociedade civil." ${ }^{169}$.

Trata-se, por um lado, de uma ignorância da História, pois há inúmeros relatos da presença de sufis em movimentos políticos ${ }^{170}$. Por outro, trata-se de um "véu desencantado" que nos impede de entrar em contato com as afirmações feitas pelos sufis sem o habitual antagonismo "interior x mundo externo".

Olhar "para dentro" ou "para fora", a rigor, tanto faz. "Nós os faremos ver Nossos signos nos horizontes e em si mesmos." (Cor, 41:53). Se a relação com as coisas é uma relação de significação, há um trabalho constante a ser feito nessa direção. Em primeiro lugar, comprar uma coca-cola, participar de movimentos políticos ou aprender economia pode ser uma atividade de autoconhecimento ou não. Em segundo lugar, se um trabalho de autonomia consiste em compreender-se como integrado a múltiplas instâncias da vida e fazer face às múltiplas respostas que cada instância exige, torna-se evidente que há mais matéria de autoconhecimento na política que na compra de uma coca. A idéia posta em primeiro lugar cumpre o papel de evitar fundamentalismos nos quais fixaríamos hierarquias para os comportamentos.

O autoconhecimento não pode ser diferente de nenhum conhecimento, de nenhuma atividade. Ele não consiste num processo de exclusão nem de escolha. Ele é trabalho sobre a realidade, portanto, sobre o ego, portanto, é busca de verdade. A vileza a ser combatida é tanto a inveja "individual" que se alimenta de uma paixão egóica quanto a pobreza planetária promovida pela generalização do sistema capitalista. Não há uma vileza interna e outra, distante, externa. Não há vileza que possa ser ignorada porque o ego não é um corpo fechado, um domínio delimitado, ego é uma perspectiva. Dito de outro modo, não há solidão nem decisões solitárias porque não há lugar sem Deus, portanto, sem resposta.

Obviamente, há pessoas que não possuem as condições materiais para combater a vileza "planetária", por esta razão é preciso cuidado nestas considerações, caso contrário estaremos inventando uma cruzada moral, tão insensata quanto abstrata.

Na perspectiva do Encantamento, o "mal" é um só e, por esse motivo, combater o "inimi-

\footnotetext{
${ }^{169}$ Muhammad Khatami, Diálogo entre civilizações, op. cit., p. 49-50.

${ }^{170}$ Cf Idries Shah, The Sufis, Chodkiewicz, Le Sceau des Saints, obras citadas.
} 
go mais próximo" quer dizer combater o mais distante. Mas, se compreendermos esta idéia complexa como uma permissão moral para que cada um cuide da sua vida e esqueça tudo o mais, estamos, mais uma vez, comerciando ouro falso.

Aquele que conhece a si mesmo, conhece o seu Senhor, disse o Profeta. A primeira implicação desta fala é que Deus encontra-se no coração de seu fiel servidor, isto é, no lugar mais central. Assim, numa primeira aproximação, o simbolismo do coração não é um despiste: o coracão está de fato "dentro", dentro do corpo e da alma. No entanto, corpo e alma são linguagens em constante relação já que todos foram feitos "de uma alma única". Cada totalidade relaciona-se com totalidades, o dentro é igualmente o horizonte.

Traduzo agora o que acabo de dizer para uma outra perspectiva, a meu ver, perfeitamente harmônica com o que aqui se focaliza, novamente, pelas palavras de Marilena Chauí, intérprete de Merleau-Ponty:

Abraçados e enlaçados, Espírito Selvagem e Ser Bruto são a polpa carnal do mundo, carne de nosso corpo e carne da coisas. Carne: habitada por significações ou significações encarnadas, as coisas do mundo possuem interior, são fulgurações de sentido, como as estrelas de Van Gogh; como elas, nosso corpo não é uma máquina de músculos e nervos ligados por relações de causalidade e observável do exterior, mas é interioridade que se exterioriza, é e faz sentido. Se elas e nós nos comunicamos não é porque elas agiriam sobre nossos órgãos dos sentidos e sobre nosso sistema nervoso, nem porque nosso entendimento as transformaria em idéias e conceitos, mas porque elas e nós participamos da mesma Carne. A Carne do Mundo é o que é visível por si mesmo, dizível por si mesmo, pensável por si mesmo, sem, contudo, ser um pleno maciço, e sim, paradoxalmente, um pleno poroso, habitado por um oco pelo qual o positivo contém nele mesmo o negativo que aspira por ser, uma falta no próprio Ser, fissura que se preenche ao cavar-se e que se cava ao preencher-se. Não é, pois, uma presença plena, mas presença habitada por uma ausência que não cessa de aspirar pelo preenchimento e que, a cada plenitude, remete a um vazio sem o qual não poderia vir a ser. A Carne do Mundo é o quiasma ou o entrecruzamento do visível e do invisível, do dizível e do indizível, do pensável e do impensável, cuja diferenciação, comunicação e reversibilidade se fazem por si mesmas como estofo do mundo.

Merleau-Ponty fala em deiscência da Carne, usando um vocábulo empregado em botânica para referir-se à abertura espontânea dos órgãos dos vegetais quando alcançam a maturidade, dispostos a fecundar e a ser fecundados. Deiscência da Carne significa que a Carne - do mundo e nossa - é o originário e este é gênese interminável que pede, exige nossa criação para que possamos experimentá-lo; e podemos responder ao seu apelo porque somos feitos da mesma polpa insondável que ele. Somos espíritos verdadeiramente encarnados. ${ }^{171}$

\footnotetext{
${ }^{171}$ Experiência do Pensamento, op. cit., p.155-6.
} 
Ainda que eu não possa alongar-me sobre o tema, que está além do escopo deste trabaIho, vale observar que a diferença entre a "alma única" e a "Carne do Mundo" não deve nos despistar. A separação entre "alma" e "corpo", tal como a conhecemos na Modernidade e que Merleau-Ponty critica e desfaz, não se dá em Ibn 'Arabî.

As histórias de ensinamento que aqui focalizo são instrumentos forjados pelos sufis. Elas atravessam os séculos e as culturas, "cabem" nas mais variadas circunstâncias, estão dispensadas dos limites de um certo racionalismo, pois estão envoltas em "pensamento mágico". Elas são material pedagógico encantado no sentido de que devem ser escutadas não somente em seu conteúdo, mas também e sobretudo, em sua harmonia interna, pois a urdidura está presente de modo tácito na trama.

A menção feita à curiosidade infantil, no texto de Regina Machado, encontra ressonância com um termo técnico abordado por Ibn 'Arabî.

O Profeta Muhammad é qualificado no Corão (7:157-8) como ummî, normalmente traduzido por "analfabeto". No Lisân al-arab, o termo é definido como "aquele que é tal como sua mãe o deu à luz"

Mas, para Ibn 'Arabî, que dedica à noção de ummiyya um capítulo dos Futûhât, pode-se ser ummî sem ser analfabeto desde que o intelecto seja capaz de suspender suas operações ("A ummiyya, para nós, consiste em renunciar a usar a especulação e o julgamento da razão para fazer surgir as significações e os segredos"). A exemplo do Profeta, receptor virginal da Revelação, o ser deve abrir-se por inteiro às luzes da graça. Isto não implica em que toda atividade intelectual deva ser proscrita como contraditória em relação a esta disposição em acolher uma iluminação sobrenatural: Abd al-Karîm al-Jîlî, entre muitos outros discípulos do Shay $\underline{\underline{h}}$ al-Akbar ${ }^{173}$, insiste, ao contrário, na importância dos livros como suportes da baraka e como instrumentos de aperfeiçoamento espiritual (...).

Mas, há um tempo para cada coisa e Deus só fala no silêncio da criatura. Para ouvi-lo, o homem deve retornar ao "estado de infância" - expressão que seria, no fundo, a tradução mais exata de ummiyya. Este estado infantil é o que o Corão descreve nos seguintes termos: "Deus vos fez sair do ventre de vossas mães e não sabíeis nada" (16:78). Entre as significações possíveis de uma palavra, de um verso, não há que escolher por meio de um processo mental: o "verdadeiro" sentido - o que é verdade neste instante preciso, para este ser preciso - é o que surge, na nudeza do espírito, da letra mesma do discurso divino. É a esta letra, e a ela somente, que prestará atenção aquele cujo coração está pronto a acolher esta "chuva de estrelas" que cessará apenas no dia em que o Corão não for mais recitado "em voz alta ou em segredo". ${ }^{174}$

\footnotetext{
${ }^{172}$ Cit e trad por Chobkiewicz, in Océan, p. 52.

173 Título dado a Ibn 'Arabî que significa "o maior dos mestres" ou "o mestre por excelência".

${ }^{174}$ Chodkiewicz, Océan, p. 54.
} 
Numa outra passagem, comentando uma frase de Ibn 'Arabî, Chodkiewicz nos ajuda a entender melhor que seria essa suspensão do intelecto.

"Ó intelecto, dirige-te ao teu lugar de oração a fim de que Ele recite sobre ti Sua Palavra. Abandona tua crença (i'tiqadaka). Não faças reflexões no momento em que Ele te fala. Não penses sobre o que responderás" ${ }^{175}$. O i'tiqâd - traduzido aqui por "crença" - não é simplesmente a fé. Como aql, intelecto, este vocábulo é formado a partir de uma raiz que significa "ligar", "amarrar". O i'tiqâd é uma ligadura, uma concepção ou uma imagem mental na qual encerramos a infinitude divina. Retornar à ummiyya é uma condição sine qua non da escuta do discurso divino. A este discurso, o intelecto que o acolheu nada tem a responder: ele ouvirá a resposta que Deus cria nele. ${ }^{176}$

Compreendida como instrumento pedagógico, a história de ensinamento não apenas exige essa suspensão das crenças ou, conforme o termo que estivemos utilizando até aqui, das identificações, como também ela propicia essa suspensão. Ela atua, por assim dizer, de modo a distrair o ego e a atividade compulsoriamente racionalizadora. Entregar-se a sua audição (ou a sua leitura) é em si um exercício de desapego. Frequentá-la repetidamente é um trabalho de abertura à sua totalidade, comparável à visitação ritual que um buscador da verdade faz a um lugar sagrado ou à tumba de um santo, para escutar a eloquência do seu próprio silêncio. Retomo um texto de Ibn 'Arabî já citado.

"Sou Eu que recito Meu Livro para ele, por sua língua, enquanto ele Me ouve: e é essa Minha conversa noturna com ele. Esse servidor saboreia Minha palavra. Mas, se ele se detém em seus significados, sai de Mim por sua reflexão e sua meditação. Pois o que lhe cabe é apenas inclinar-se em Minha direção e tornar sua audição perceptiva à Minha Palavra até que Eu esteja presente nesta récita. $E$ da mesma forma que sou Eu que recito e Eu que o faço ouvir, sou Eu também que Ihe explico Minha Palavra e Ihe interpreto os significados. Esta é a Minha conversa noturna com ele. Ele toma a ciência de Mim e não de sua razão e de sua reflexão e não se preocupa mais em pensar no paraíso, no inferno, na prestação de contas, no Julgamento, nesse baixo mundo ou no mundo futuro pois ele não considera mais essas coisas por meio de seu intelecto, ele não escrutina mais cada versículo com sua reflexão: ele se contenta em abrir os ouvidos ao que Eu Ihe digo. E ele é então testemunha, presente Comigo; e sou Eu que me encarrego de sua instrução." 177

Desse modo, um trabalho pedagógico com histórias da Tradição imemorial deverá levar em conta todas essas dimensões: a história é uma marca simbólica, ela nos leva "para dentro" e para "outro mundo", para o Corão, isto é, para o plano da Revelação, e para a

\footnotetext{
175 Ibn 'Arabî, Tanazzulât, p. 84.

${ }^{176}$ Chodkiewicz, Océan, op. cit., p. 137-8.

${ }^{177}$ Ibn 'Arabî, cit e trad. por Chodkiewicz, in Océan, p. 48.
} 
"Terra da Realidade" (ard al-haqîqa) ${ }^{178}$, para o atual e para o Mundo Encantado. Ela nos conecta não com a Origem imaginária, feita de nostalgia e de passado, mas sim com a Origem simbólica, esta que é Real e ao mesmo tempo feita de por fazeres.

Nesta perspectiva, do mesmo modo que não há uma "receita" genérica ou abstrata para o uso de um verso do Corão ou de um Nome de Deus - é um contrasenso dizer que tal Nome de Deus é "bom para" quando se está triste ou com falta de dinheiro - não há uma história apropriada para se "trabalhar uma questão". A homeopatia nos aporta uma analogia clarificadora: se perguntarmos a um homeopata unicista qual o remédio "bom para" dor de estômago, ele responderá: "o seu remédio, aquele que lhe é próprio, aquele que "atua" na integridade da sua pessoa". Não há, portanto, relação de causa e efeito a partir de uma forma simbólica. Não há uma história "boa para".

"Nós os faremos ver Nossos signos nos horizontes e em si mesmos" (Cor, 41:53), há, portanto, a referência interna e a externa, o ponto e a circunferência. Trata-se de referências simbólicas, isto é, urdiduras vazias, que podem mostrar-se nas mais variadas tramas, uma delas sendo, por exemplo, a pessoa no centro e a comunidade em volta. Nesse caso, a comunidade não é aquele conjunto de pessoas fechadas e submetidas a uma formação discursiva voltada para a conservação. Ela é a referência ao Encantamento, ao lugar da origem simbólica, à fonte de renovação, portanto de frescor e atualidade permanentes. É pela comunidade humana, no espaço público onde são travados seus embates, onde são formuladas suas questões, onde são produzidos seus atos de entrega e risco, que a renovação é inventada e re-inventada.

Saira Shah, contando em seu livro diálogos com seu pai, Idries Shah, nos oferece uma alusão preciosa.

Quando eu estava com quinze anos, a União Soviética invadiu e ocupou o Afeganistão. Pouco depois, durante uma sessão culinária em que se preparava pilau, expressei uma ansiedade que vinha sentindo fazia algum tempo. Como meu pai podia esperar que fôssemos realmente afegãos, se havíamos crescido fora de uma comunidade afegã? Quando voltássemos para nossa terra, não seríamos estrangeiros, forasteiros em nossa própria pátria? Eu esperava ouvir o relato reconfortante de nosso retorno triunfal e iminente a Paghman. Não ouvi. Meu pai estava cansado e triste. Sua resposta me surpreendeu: "Eu lhes contei histórias para substituir a comunidade. As histórias são sua comunidade".

"Mas as histórias não substituem a experiência."

Ele pegou um pacote de cebola desidratada. "As histórias são como estas cebolas - como experiência seca. Não são a experiência direta, mas são melhores que nada. Você reflete sobre uma história, você a remói na mente, e ela se torna outra coisa." Ele despejou água quente na cebola. "Não é cebola fresca - experiência fresca -, mas é algo que pode ajudar a reconhecer a experiência quando ela

\footnotetext{
${ }^{178}$ Que foi modelada, segundo Ibn 'Arabî, a partir do resto da argila de Adão e está situada no Mundo Imagi-
} nal (alâm al-hạayâl). 
acontecer. As experiências seguem determinados padrões que se repetem indefinidamente. Em nossa tradição, as histórias podem ajudar a reconhecer a forma de uma experiência, a entendê-la e a lidar com ela. Portanto, o que a seus olhos talvez não passe de mito e lenda, contém o que você precisa para guiá-la entre os afegãos em qualquer lugar". ${ }^{179}$

"As experiências seguem determinados padrões que se repetem indefinidamente" e "as histórias podem ajudar a reconhecer a forma de uma experiência" parecem aludir a essa urdidura sustentadora e à importância de tomar a história como uma totalidade - que não pode ser dividida, nem analisada, nem estudada a partir de atributos em si das personagens - e como um guia para a experência atual.

"As histórias são sua comunidade", elas funcionam como a cena pública na qual os dramas são atravessados de modo a cumprir o mesmo papel da comunidade. Dito de outro modo, a "comunidade" é, antes de tudo, uma forma simbólica do Outro.

Todos os mestres dizem que o tesouro espiritual é um descobrimento solitário, então, por que estamos juntos? - perguntou um dos discípulos de Nasrudin. Vocês estão juntos porque um bosque é sempre mais forte que uma árvore solitária - respondeu Nasrudin - o bosque mantém a humidade do ar, resiste melhor a um furacão, faz com que o solo seja fértil. - Mas o que faz uma árvore forte é sua raiz. E a raiz de uma planta não pode ajudar outra planta a crescer - disse o discípulo. - Estar juntos num mesmo propósito é deixar que cada um cresça a sua maneira; este é o caminho dos que desejam estar em comunhão com Deus.

${ }^{179}$ Saira Shah, A filha do contador de histórias..., op. cit., p. 15. 


\subsection{A REALIDADE COMO LINGUAGEM}

Escrever é o modo de quem tem a palavra como isca: a palavra pescando o que não é palavra. (Clarice Lispector)

Entre Merleau Ponty e Ibn 'Arabî, passo agora a desenhar minhas sínteses.

Ao imaginarmos a longa travessia de um compositor para construir sua obra musical, podemos supor suas idas e vindas. Podemos vê-lo às vezes particularmente solto e fluente sob uma inspiração finalmente conquistada depois de horas de tentativas aparentemente vãs entre as teclas de seu piano. Em outros momentos, podemos observá-lo entregue a uma curiosa mecanicidade, como se ele mesmo estivesse ausente de sua criação e não a quisesse ou não acreditasse nela. Sabemos que ele sofre, goza, anseia, se desespera e se rejubila. Sabemos que o trabalho de composição não é totalmente diferente de uma guerra, de uma cópula ou de uma semeadura.

O que me interessa aqui é a analogia entre todos esses "planos de realidade". Na composição, há um algo pré-estabelecido - uma busca essencial de gozo - e algo que, a posteriori, manifestará o gozo "alcançado". Ao longo da travessia, o trabalho é aproximar-se, como for possível, do gozo e dar-se conta, como na cópula, se ele está próximo ou não. Esse "dar-se conta" é um enorme exercício de diálogo com um conjunto de parâmetros que permitirá decidir sobre a experiência. Porque esse conjunto de parâmetros não é fixo e porque se trata de um diálogo, podemos dizer que o músico dialoga com a música, isto é, com o outro que, no caso, é a música e o faz por meio da linguagem musical.

Importante, então, precisar: seu diálogo não é com a liguagem musical, é com o seu gozo por meio de uma liguagem - íntima, singular e única - que se apropria da linguagem musical para tornar-se fala, proposta, endereçamento ao gozo. 
Como ele "sabe" que não é esta nota a que ele quer agora? Em parte porque a linguagem musical possui leis que ele conhece e porque ele possui um desejo que desconhece mas atualiza a cada momento por meio das leis tanto da linguagem musical quanto da linguagem de seu desejo.

O gozo e o desejo, o destino e a origem, não são coisas. Podem ser vistos como pontuais ou como momentos. Mas podem também ser vistos como linguagem. Ora como um, ora como múltiplo. Ora como luz, ora como letra ou forma.

Enquanto linguagens, são estruturas grávidas de significação que buscam outras linguagens nas quais traduzir-se.

Este "saber da nota certa" não é inteiramente consciente. Há nele aspectos de consciência e de percepção em vários níveis, aspectos que passam desapercebidos e podem ser chamados de pré-conscientes e há também, é claro, aspectos inconscientes ${ }^{180}$.

De um lado, uma linguagem tangível e suas leis, de outro, a linguagem do desejo de um gozo ainda misterioso que ultrapassa essa linguagem tangível mas que depende dela para fazer-se experiência.

Como são as leis de uma linguagem? São as leis que determinam o que pode ser atualizado dela, conforme um certo tempo, um certo lugar e uma certa pessoa ou grupo de pessoas.

Não compartilho do abandono, feito pelos filósofos pós-modernos, do termo "linguagem", tornado vazio depois de sua exaustiva exploração no século XX: ele me é útil no presente contexto por me permitir trabalhar em "grandes segmentos", isto é, por viabilizar uma articulação entre estrutura e história e, pela via da idéia de atualização, entre estrutura, história e sujeito.

Desse modo, a acepção de linguagem com que trabalho corresponde a uma síntese que proponho aqui: linguagem é toda organização harmônica que possui um aspecto fixo $e$ estruturado e outro maleável conforme o tempo, o lugar e as pessoas nela envolvidas. É trama e é urdidura.

Eis uma outra metáfora: um navegante utiliza o céu para navegar. As estrelas são fixas ${ }^{181}$, isto é, estão acima do mar e são independentes dele, mas elas não podem, a priori, indicar ao navegante aonde ele quer ir, elas só podem dizer-lhe - a partir do momento em que

\footnotetext{
180 O Inconsciente freudiano "cabe" no Sufismo como qualquer diálogo com o atual cabe, o que exige, claro, uma articulação entre ambos dentro da mesma proposta de "diálogo transcultural" com o Encantamento.

${ }^{181}$ Note-se que dizer que as estrelas são fixas é uma força de expressão: além de, como disse Ibn 'Arabî (e tantos outros), não haver nada fixo no universo, as constelações são um recorte, obviamente, variando, de cultura para cultura, de época para época. Sua fixidez corresponde, na realidade, à mesma exigência simbólica presente no par trama e urdidura, atualidade e escrita, etc.
} 
ele deseja um certo lugar aonde ir - por onde ir para chegar lá. Quanto mais obediente às estrelas ele for, mais seguramente chegará no destino desejado. Sem o desejo, no entanto, as estrelas são mudas. Elas só se tornam linguagem perante este algo anterior decidido no íntimo do sujeito e cujo nome é destino. O destino, portanto, está escrito nas estrelas e, porque está escrito, não está definido nelas. Dito de outro modo, o que está escrito nas estrelas é a urdidura, a trama sendo o avesso do desejo, isto é, sua realização fictícia, sua descobridura, a flor como a mostração da semente ${ }^{182}$.

Quanto mais obediente às leis da linguagem musical, mais próximo de seu gozo destinado estará o músico. E, o que é importante, as leis da linguagem musical não são as que Debussy infringiu para compor seu "Claire de Lune". O que ele infringiu foi um certo código de convenções, de uma certa época, de uma certa mentalidade. Claire de Lune passa a ser a vitória do diálogo com as leis da linguagem musical que permitiram a Debussy encontrar um novo caminho. As leis de uma linguagem são, ao mesmo tempo, fixas e eternamente renovadas. São leis combinatórias e não regras. São como um caleidoscópio, no qual a ordem e a harmonia estão sempre presentes, a cada movimento aparecendo de um modo diferente. O fixo e o mutável atuando em conjunto, o rigor e a flexibilidade indissociados.

Aqui vemos ressurgir o fantasma do "universal". Esta linguagem musical a que me referi acima como sendo independente das convenções de uma época seria "acima" de qualquer época? Da história? Das culturas?

Claro que não. A linguagem musical de Debussy, por exemplo, parte da música tonal, o que já exclui uma centena de épocas e culturas. Por um lado, a inovação do autor se dá por comparação, quando ela nos aparece como diferente do que se fazia antes. Nesse caso, as próprias convenções ou regras infringidas são o parâmetro dessa comparação e, portanto, fazem necessariamente parte da linguagem musical. O material utilizado por Debussy é claramente datado, típico de um momento, ideológico (porque marcado por uma visão de música, de experimentação estética e deleite oriundos de uma certa classe social) e preso a todos os condicionantes espaço-temporais que possamos vislumbrar.

Por outro lado, há algo de libertário em sua obra, no sentido de que ultrapassa alguns condicionantes e constitui, no dizer de Merleau Ponty, excessos. Minha questão agora é desmisturar essa rede de condicionantes e conceber níveis dessa experiência de liberdade de invenção.

Inicialmente, quero distinguir a rede de condicionantes que é estritamente ideológica, essa que impõe aos cidadãos postos sob qualquer sistema capitalista a busca de uma "liberdade criativa" voltada para o mercado e suas exigências. Interessa-me buscar identificá-la,

\footnotetext{
${ }^{182}$ Como vimos na nota 90, o termo "desejo" não aparece, na Mística, com a sua acepção moderna e sua relação com uma idéia particular de destino, como mostra Marilena Chauí, in Desejo, op. cit. Como sempre, - Sufismo possui variados termos, para dar conta de variadas nuances, daquilo que, numa visão genérica, chamamos hoje, sobretudo na Psicanálise, de desejo. Alguns termos da Mística podem ser traduzidos por "aspiração", "chamado", "vocação", "intenção", "energia espiritual", etc.
} 
criticá-la, anulá-la e partir da proposta que tantos autores já fizeram: que a liberdade em relação a ela seja contraditória, isto é, que este tipo de liberdade exige que nos livremos, o quanto possível, dessa ilusão aprisionadora.

Em seguida, quero distinguir a idéia de linguagem como algo que difere da ideologia porque é fruto de uma realidade histórica, porém, não está submetida estritamente aos interesses de classes hegemônicas ou de qualquer poder.

Esta linguagem, ou conjuntos de linguagens, encontrar-se-ia num plano diferente do da ideologia, como conjuntos de possibilidades que podem ser atualizadas em ações de pessoas ou de grupos, que podem ser, inclusive, contrárias à ideologia vigente. Para mim, neste presente trabalho, passa a ser fundamental distinguir a ideologia a todo momento. Isso porque, ao distinguir a ideologia como malha capturante, posso buscar ver e fazer ver os movimentos da construção humana que emergem como superação de condicionantes e que, como tais, podem ser "modelos excelentes" (Corão, 33:21) para um pensador da educação no nosso tempo ${ }^{183}$.

Onde "estão" essas linguagens? Estão na história e na cultura, que são obviamente maiores que a ideologia ${ }^{184}$. Retomo aqui, em certa medida, a idéia de estrutura em Merleau Ponty.

Assim, há uma outra liberdade que, ao contrário da primeira, não consiste em livrar-se de uma rede de condicionantes. Trata-se aqui de assumir estas linguagens, de obedecer a elas como o navegante obedece às estrelas. Trata-se de ter na história e na cultura um tecido de significações que, ao ser "obedecido" permite que dele manifestemos novos significados, criações, críticas, elaborações e conhecimento. Trata-se, portanto, de um diálogo com a história e com a cultura.

No entanto, seria evidentemente ingenuidade supor que é fácil, ou mesmo possível, distinguir a ideologia das outras linguagens presentes nessa construção. A rigor, não se trata de uma distinção como se houvesse uma trama ideológica distinta, como uma planta parasita é distinta da árvore que ela captura. A distinção também é plástica e cambiante e, nesse sentido, deve ser pensada também como uma liguagem: num certo momento, num certo lugar, um certo grupo humano deveria poder atravessar a herança de seus antecessores e haver-se com as questões de transmissão de sua própria herança para os seus descendentes, isto é, com a educação; e esta distinção também deverá variar conforme o tempo, o lugar e as pessoas envolvidas. Dito de outro modo, um mesmo aspecto de uma herança pode ser visto como ideológico ou como, digamos, libertador, dependento da atualização que possa ser feita, num determinado momento, desse aspecto tornado linguagem.

Assim, retomando o que foi dito nos primeiros parágrafos deste capítulo, temos que o

\footnotetext{
${ }^{183}$ Sendo a idéia de modelo conforme vimos no capítulo 2.2.

${ }^{184}$ O termo "maiores", aqui, não implicando, evidentemente, nenhuma hierarquia.
} 
músico dialoga com o seu gozo por meio de uma linguagem - íntima, singular e única que se apropria da linguagem musical para tornar-se fala, proposta, endereçamento ao gozo. Agora, esta linguagem musical é uma forma da linguagem que é a história e a cultura.

Há um número infindável de linguagens dentro desta, por assim dizer, macro-linguagem que é o cruzamento espaço-temporal da história com a cultura.

No capítulo 2.3, chamei de Outro qualquer tipo de alteridade, de modo a construir uma dualidade operativa, isto é, qualquer relação dual, por mais particular que seja, refere-se a uma dualidade total - ou, simplesmente, a uma totalidade - de modo que possamos aludir a todas as linguagens que permeiem esta relação "particular".

Assim, o músico dialoga com seu gozo por meio de uma linguagem - íntima, singular e única - que se apropria do diálogo com o Outro para tornar-se fala, proposta, endereçamento ao gozo.

E onde "está" essa linguagem íntima, singular e única que á a linguagem do desejo? Ela está na história e na cultura? "Pertence" ao Outro?

No contexto do presente trabalho, estou dizendo que a linguagem do desejo - entendendo-se o desejo como esse movimento singular expresso pelos termos técnicos já citados: "aspiração", "chamado", "vocação", "intenção", "energia espiritual", etc. - seria a Escrita.

A linguagem é, nesse sentido, um conjunto estruturado de possíveis que podem ou não se manifestar. O que permite que um possível se emancipe é o desejo do sujeito que põe a linguagem para falar, o navio para navegar, o piano para tocar.

O sujeito é, nesse sentido, o lugar onde a linguagem toma a forma de uma fala, onde ela acontece. Claire de Lune aconteceu primeiramente num lugar chamado Debussy. Nesse caso, com toda a evidência, Debussy não seria um centro fixo, positivo. Ele todo é uma linguagem, em permanente re-arranjo.

Para Ibn 'Arabî, toda a realidade é linguagem e tudo o que acontece, acontece num lugar chamado sujeito ou grupo de sujeitos. Assim, quando dizemos que alguém é um "bom compositor", dizemos que ele conhece a linguagem musical a ponto de saber como ela pode atualizar o seu desejo de músico. Do mesmo modo, analogamente, o "sujeito encantado" é aquele que conhece a linguagem da "realidade" a ponto de saber como ela é Escrita, isto é, como ela pode atualizar o seu desejo de homem.

Agora, como sabemos, o desejo não se atualiza abstratamente, de modo independente das relações do sujeito com os outros, com o tempo e o lugar em que vive. Tampouco escapa da rede ideológica que se interpõe entre as linguagens e o sujeito. 
Se podemos dizer que, na perspectiva do Encantamento, tudo é linguagem, então, os outros, o tempo, o lugar são linguagens e a fala do sujeito, cada fala, toda fala é um ponto de cruzamento entre todas essas linguagens. Cada fala é uma atualização, portanto, não de uma, mas de diversas, na verdade, de incontáveis linguagens.

Esse modo de pensar as coisas não é uma extrapolação indefinida da idéia de linguagem. Ele obedece a um método analógico de pensamento e tem o objetivo de permitir a construção de um modelo.

Se cada fala é uma atualização de inúmeras linguagens, podemos dizer não que ela possua múltiplos aspectos mas sim múltiplas, digamos, dimensões de realidade. E que ela pode ser lida ou escutada nessas várias dimensões.

Foi nesta direção que li o seguinte pensamento de Merleau-Ponty:

"A concepção do direito, a moral, a religião, a estrutura econômica significam-se umas às outras na Unidade do acontecimento social, assim como as partes do corpo implicam-se umas às outras na Unidade de um gesto, ou como os motivos "fisiológicos", "psicológicos" e "morais" se ligam na Unidade de uma ação, e é impossível reduzir a vida inter-humana seja às relações econômicas, seja às relações jurídicas e morais pensadas pelos homens, assim como é impossível reduzir a vida individual seja às funções corporais, seja ao conhecimento que temos dessa vida. Mas, em cada caso, uma das ordens de significação pode ser considerada dominante, tal gesto como "sexual", tal outro como "amoroso", tal outro enfim como "guerreiro", e, mesmo na coexistência, tal período da história pode ser considerado como sobretudo cultural, em primeiro lugar político ou em primeiro lugar econômico. A questão de saber se a história de nosso tempo tem seu sentido principal na economia e se nossas ideologias só lhe dão seu sentido derivado e segundo é problema que não depende mais da filosofia e sim da política, e que se resolverá investigando qual, entre o cenário econômico e o cenário ideológico, recobre mais completamente os fatos. A filosofia pode mostrar apenas aquilo que é possível a partir da condição humana." ${ }^{185}$

Articulam-se assim desde dimensões muito distintas e distinguíveis, como a escuta de um médico, de um acupunturista, ou de um arquiteto até as dimensões mais difíceis de distinguir como as posições imaginárias que condicionam a escuta em tal ou tal direção.

Assim sendo, uma coisa é pensar em aspectos da fala. Por exemplo, cada fala pode ser interpretada de modos diversos, depende de quem a escute. Nesse caso, estamos falando de ângulos da "realidade", de pontos de vista.

Outra coisa é pensar na fala como um portal de linguagens. Não se trata mais de pontos

${ }^{185}$ pp. 635-6. 
de vista, de ângulos dentro de um mesmo campo de visão. Trata-se de campos, de realidades diferentes. Porque se trata de linguagens diferentes. E, aqui, a utilização da idéia de linguagem permite dizer o seguinte: que a realidade é um conjunto estruturado de possíveis que podem manifestar-se por meio de lugares chamados sujeitos e que esse conjunto de possíveis é, na verdade, um conjunto de conjuntos de possíveis.

Dito de outro modo, pensar a realidade como linguagem torna-a, ao mesmo tempo, estruturada e indefinida, unificada e múltipla, fixa e mutável, abarcante e abarcável, indefinível - como se pode definir, enquanto linguagem, o português ou o francês ou o ballet ou o flamenco? - misteriosa e incessantemente decifrável.

Dito ainda de outro modo, o outro - o "pequeno outro", não o "grande outro" - que também passa a ser uma linguagem, torna-se um lugar privilegiado de diálogo: não tão feminino ${ }^{186}$ como a música e o piano, portanto, não tão plástico nem tão passivo, ele possui desejo próprio. Não apenas, como todas as coisas, ele atrai, incita e exige nossa decifração, como também ele quer decifrar.

Dialogar com o outro já não é, então, apenas encontrar a "nota certa" de uma sinfonia sonhada na origem, mas é encontrar o harmônico de uma linguagem criada no instante - e a cada instante - em que esse outro se põe para nós como lugar de Mistério e de recriação.

A "nota certa" para ambos é também uma nota fora da história de ambos, transcendente a ambos e imanente ao momento em que apenas o puro diálogo é o que importa.

"- Oh, sê outro nome! Que há em um nome? O que chamamos de rosa, com outro nome, exalaria o mesmo perfume tão agradável; e assim, Romeu, se não se chamasse Romeu, conservaria essa cara perfeição que possui sem o título. Romeu, despoja-te de teu nome e, em troca de teu nome, que não faz parte de ti, toma-me toda inteira!

- Tomo-te a palavra. Chama-me somente 'amor' e serei de novo batizado. Daqui para diante, jamais serei Romeu." ${ }^{187}$

Sendo sem nome, a "cara perfeição" não possui nem passado, nem história, nem tempo, nem forma. Esse puro diálogo comporta algo de profundamente semelhante à linguagem do gozo pois é quase como se, nesse momento, dispensassem-se todas as línguas conhecidas, como a música, as palavras e até mesmo o sexo e fosse possível uma eloquência sem fala, diáfana e sem pouso, soprada do encontro direto entre duas intangíveis linguagens de desejo.

\footnotetext{
${ }^{186}$ A escolha do termo "feminino" aqui obedece a um propósito. Em antigos textos místicos, esse termo jamais foi confundido com a mulher, sujeito, cidadã, indivíduo ou pessoa do sexo feminino. O feminino é um atributo de ordem cosmológica e não implica, como uma certa mentalidade assim o quis, que a mulher deva ser exclusivamente plástica e passiva e obediente, etc. Discorri extensamente sobre esta confusão entre o simbólico e o imaginário no já citado "Sentidos do Caleidoscópio...".

${ }^{187}$ Shakespeare, Romeu e Julieta, in Obra Completa, op.cit., p. 307.
} 
Do que se fala nada fica. Nem na consciência. Nem na memória. A perplexidade, que é uma experiência encantada por excelência, é essa suspensão integral da linguagem frente ao Real do gozo. Cito o mestre Rumî ${ }^{188}$ :

Vem.

Conversemos através da alma.

Revelemos o que é secreto aos olhos e ouvidos.

Sem exibir os dentes, sorri comigo, como um botão de rosa.

Entendamo-nos pelos pensamentos, sem língua, sem lábios.

Sem abrir a boca, contemo-nos todos os segredos do mundo, como faria o intelecto divino.

Fujamos dos incrédulos

que só são capazes de entender

se escutam palavras e vêem rostos.

Ninguém fala para si mesmo em voz alta.

Já que todos somos um, falemos desse outro modo.

Como podes dizer à tua mão: "toca", se todas as mãos são uma?

Vem, conversemos assim.

Os pés e as mãos conhecem o desejo da alma.

Fechemos pois a boca e conversemos através da alma.

Só a alma conhece o destino de tudo, passo a passo.

Vem, se te interessas, posso mostrar-te. ${ }^{189}$

Evidentemente, nada disso acontece quando o outro está "reificado" numa pessoa dotada de "personalidade", de "qualidades", de forma fixa, numa palavra, de ego.

Redizendo de outro modo o que foi dito anteriormente, estabeleço que o ego é o que pode ser visto como o outro lado da linguagem ${ }^{190}$. A possibilidade de que algo seja dito, que

\footnotetext{
${ }^{188}$ Rumi (sec XIII), um dos maiores mestres sufis, autor do Masnavi, considerado "o Corão persa".

${ }^{189}$ Poemas Místicos, op. cit., p. 60.

${ }^{190}$ Neste primeiro momento, estabeleço uma dualidade composta de ego e linguagem na qual há uma clara hierarquia entre ambas, sendo a segunda, evidentemente, "superior" à primeira. Em seguida, esta dualidade
} 
tome a forma de uma fala qualquer, é também a possibilidade de que essa forma se cristalize, se torne definida e definitiva, se "institucionalize". Ego, sendo ilusão de continuidade, de fixidez e de permanência, nesse caso, é apego a uma fala, a uma versão, a um porto seguro alheio à precisão do navegar e à necessidade das estrelas. Ele se define como um centro fixo, cheio de imagens e representações, como uma certeza apriorística imaginária e, a partir daí, passa a produzir suas navegações imaginárias, aparentemente livres e criadoras, porém circunscritas a uma imagem da realidade, imagem esta também fixa, sobre a qual tudo se move.

A certeza de que "eu sou eu" ou "eu sou assim" é igual à certeza de que "esta cadeira é uma cadeira". O fato de que possamos duvidar da existência da cadeira não altera em nada a tranquilidade com que abandonamos nosso corpo no ato de sentar, seguros de que ela não se moverá. $O$ ego necessita conhecer as leis que permitem que a cadeira se mova ou fique no lugar. Necessita também saber como é esse "assim" que "eu sou" e as leis que regem esse "ser assim" para cada um em relação a si próprio e em relação aos outros "assins" e em relação à vida de um modo geral.

Porém, o ego também pode ser visto como linguagem.

será revista, segundo o "metodo" que estabelecemos antes. 


\subsection{AUTONOMIA COMO ACOPLAMENTO COM A LEI}

O mundo em que vivemos parece plástico e sem fronteiras. Em toda parte, ouvimos falar de rede, de intercâmbio, de globalização, de linguagens, de relações, de pensamento complexo, de desconstrução. Até as identidades, que os indivíduos chegaram a ter como um intocável porto seguro, tornaram-se cambiáveis. Mas, uma coisa é uma Lei plástica, outra coisa é uma plasticidade sem lei. Nunca fomos tão materialmente plásticos nem tão intelectualmente escravos.

A mãe disse ao filho adolescente que "aquilo era orgulho" e ele the disse, então: "Mas, como eu faço para não sentir isso?" Saber qual é a capital do Estado de Nova York e não saber como fazer para não sentir orgulho é uma condição miserável. Crer que conversar com alguém próximo, ler um bom clássico, fazer arte ou meditar sobre si é inútil e que a única opção é necessáriamente buscar um analista, também. Crer a que "a saída" é virar crente ou drogado ou fundamentalista é igual. Ou pesquisar no Google.

A posição imaginária é vivida pelo ego como real, como perturbadoramente imutável e convencer as pessoas de que "isso é assim mesmo" ou que "faz parte da vida e a gente tem que aprender a aceitar" é um desses absurdos que pais, professores, etc., professam publicamente todos os dias. A experiência subjetiva é uma construção imaginária como outra qualquer, no entanto, o quanto dos métodos básicos de desidentificação está fora de moda num tempo em que a maior parte da energia está voltada justamente para o contrário, para o consumo voraz de identificações?

Quando o juiz Nicolau, batizado pela mídia de "Lalau", foi preso por corrupção, seu genro declarou que o pródigo, quando se sentia deprimido, comprava uma nova Ferrari. Outros batem na mulher ou chantageiam o marido. Outros terminam um namoro ou um casamento. Outros humilham um subordinado ou fazem um empréstimo.

Num certo dia, o indiozinho relatou, no círculo em que todos contam os sonhos pela ma- 
nhã, que um tigre o ameaçara no sonho da noite anterior. O pajé, então, ensinou-lhe como fazer para, no sonho seguinte, começar a vencer o tigre. E assim, durante um tempo, o menino ia sonhando e relatando as mudanças gradativas que ia fazendo em seus sonhos até o cumprimento de seu objetivo. É verdade que os índios não sabem muitas coisas que nós sabemos e são prisioneiros de coisas das quais nós não somos. Mas, isso nós não sabemos. O que me importa aqui é se podemos aprender.

A autonomia resulta de um modo específico de pensar o ego, isto é, um modo do sujeito pensar-se a si mesmo. Esse modo, tratado assim pelo Encantamento, é aquele no qual o "pensar-se a si mesmo" é análogo ao "pensar o outro" e o "pensar o Outro". É aquele no qual a Política, a Ética, a Música, o Ego, o Sujeito, a folha de uma árvore, o vôo de um pássaro, a dor e a felicidade, são linguagens. Transformo a idéia de Aristóteles, de que o homem é um animal político porque possui linguagem, e faço com que ela passe a ter para mim este sentido preciso.

O trabalho de conquista da autonomia do sujeito passa pelo longo e árduo aprendizado sobre si mesmo como uma linguagem, portanto, como uma rede de diálogo com outras linguagens que, por sua vez, poderiam ser - e nisso residiria a autonomia, isto é, a capacidade de reger-se por uma lei "própria" - o diálogo com o Outro.

Este caminho de solidão encantada é um caminho público - no sentido que esta palavra vai adquirir neste contexto - porque é o caminho da conquista interna do Outro, da construção e da assumpção de uma responsabilidade perene em relação à sociedade, à cultura, à história. Portanto, é um caminho de crítica ao próprio ego enquanto "tendência" à fixação e de crítica à ideologia enquanto fixação de uma pseudo-realidade.

"Para o sufi, há quatro viagens. A primeira consiste na aquisição da condição conhecida como fana, que, às vezes, traduz-se por 'aniquilação'. É a fase da unificação da consciência, em que o sufi se harmoniza com a realidade objetiva. O propósito das ordens dos dervixes é justamente produzir essa condição." ${ }^{191}$

O que produz e permite a crítica ao ego é justamente a sua "utilização" como linguagem, isto é, como lugar da articulação entre o fixo e o mutável, entre o mesmo e o outro, o um e o múltiplo.

Alexander ${ }^{192}$ construiu uma técnica na qual se trata de ensinar a qualquer pessoa a pensar o corpo "não como uma massa mas como um conjunto de direções". Cada gesto, cada atitude corporal seria uma atualização deste conjunto de possibilidades de gestos e atitudes. Não haveria, portanto, uma postura padrão a ser conquistada mas, sim, uma linguagem

\footnotetext{
${ }^{191}$ Idries Shah, Os Sufis, p. 331. Como um sufi contemporâneo, Idries Shah "fala aos homens segundo seu grau de entendimento" (hadit). Isto é, sua obra foi destinada a leitores não versados em filosofia e para os quais a expressão "realidade objetiva" adquire um sentido o mais próximo possível do que o sufi realmente chega a entender por "realidade".

192 Explicar quem foi o pesquisador inglês Alexander e sua técnica.
} 
corporal em permanente fala. Portanto, não se trata simplesmente de um corpo flexível ou maleável, mas, antes de tudo, de um corpo "acoplado" com a estruturalidade das direções, de um corpo tornado lei, amoldado às suas possibilidades de corpo.

No Sufismo, ao ser pensado como linguagem, o ego deve buscar "amoldar-se" à Revelação - a linguagem das linguagens -, para um sufi como Ibn 'Arabî, seu objetivo pode muito bem ser descrito como "tornar-se Corão".

Pedir ao ego que se torne Corão é, analogamente, o mesmo que pedir ao corpo que se torne um conjunto de direções. É o mesmo que propor ao cidadão contemporâneo que se torne o Outro. O mesmo que pedir ao músico que se torne a música, o amante que se torne a amada, ou que pedir ao um que, no diálogo, se torne o outro.

"O objetivo do sâlik (viajante) sincero não deve ser o fath - a abertura, a iluminação - ou a visão de Deus: estas Ihe serão concedidas, em último caso, por acréscimo. O tempo que ele passa neste mundo, é na aquisição das ciências espirituais que ele deve prioritariamente consagrá-lo - entendendo-se que não se trata aqui de simples conhecimentos teóricos. A razão desta prioridade está explicitada numa passagem dos Fusûs ${ }^{193}$ :

'No dia da Ressurreição, os homens verão Deus de acordo com os graus da ciência que eles tinham a seu respeito (aqui embaixo)... Cuida, portanto, de não te encerrar numa concepção particular e de não acusar de infidelidade o que ela exclui: um bem imenso te escaparia - na verdade, é a ciência da Realidade per se que te escaparia! Aplica-te em tornar-te a materia prima de todas as representações de Deus!'."194

Identificar-se com "a matéria prima das representações de Deus", isto é, com uma matriz de possibilidades é alargar-se de tal modo que as identificações particulares se desfazem.

O que me parece ser possível pensar pelo ensinamento encantado é que o lento, paciente $e$ técnico processo de identificação com o conjunto das possibilidades articuladas de uma realidade - o que estou chamando de linguagem - permite a desidentificação com a "coisa em si" e com os discursos que a "coisificam", portanto, permite o encontro com o rearranjo, com o abandono de si e o reencontro consigo.

Se um compositor se relaciona com a linguagem musical para compor, quer dizer que ele se torna essa linguagem e passa a agir de dentro dela. Assim, ele padece às vezes de expressões físicas ou anímicas durante o seu processo de criação porque a linguagem está em ato nele. Nesse caso, dor de barriga ou melancolia não são simplesmente sintomas, são travessias necessárias. Em termos psicanalíticos, faz todo sentido olhar o sintoma pelo ângulo das construções do sujeito. Aqui, diferentemente, como a perspectiva é pedagógica, trata-se de "ensinar" o relacionamento com uma linguagem e tirar disso as conse-

\footnotetext{
193 Fusus al Hikam, obra de Ibn 'Arabî.

${ }^{194}$ Chodkiewicz, Le Sceau, p. 188.
} 
quências. Cito novamente Marilena Chauí recontando Merleau-Ponty:

Sua interrogação vem exprimir-se numa espantosa nota de trabalho de O visível e o invisível: "O Ser é o que exige de nós criação para que dele tenhamos experiência". Frase cujo prosseguimento reúne emblematicamente arte e filosofia, pois a nota continua: "filosofia e arte, juntas, não são fabricações arbitrárias no universo da cultura, mas contato com o Ser justamente enquanto criações".

Por que criação? Porque entre a realidade dada como um fato, instituída, e a essência secreta que a sustenta por dentro há o momento instituinte, no qual o Ser vem a ser: para que o ser do visível venha à visibilidade, solicita o trabalho do pintor; para que o ser da linguagem venha à expressão, pede o trabalho do escritor; para que o ser do pensamento venha à inteligibilidade, exige o trabalho do pensador. Se esses trabalhos são criadores é justamente porque tateiam ao redor de uma intenção de exprimir alguma coisa para a qual não possuem modelo que Ihes garanta o acesso ao Ser, pois é sua ação que abre a via de acesso para o contato pelo qual pode haver experiência do Ser. ${ }^{195}$

Espantosa nota, de fato, sob muitos aspectos. Minha própria experiência com esse espanto é a seguinte. Pode ou não haver experiência do Ser, não é qualquer gesto que permitirá ao pintor levar o ser do visível à visibilidade porque ele não possui um modelo que lhe garanta esse acesso. Ora, qual o trabalho que se solicita ao pintor que faz com que o ser do visível venha à visibilidade? O trabalho de acoplamento com a pintura, de tornar-se o ser da pintura.

O Shay $\underline{\underline{h}}$ assinala que a única realidade que abraça todas as coisas ${ }^{196}$ no cosmos é o wujûd $(\mathrm{Ser})^{197}$. Daí que o wujûd seja a misericórdia de Deus. Por meio dele, traz todas as coisas, a partir de um estado de inexistência dentro de seu conhecimento, onde não gozam de nenhuma dádiva, até um estado de existência no cosmos, onde podem perceber, gozar e experimentar suas próprias realidades específicas. $^{198}$

\footnotetext{
${ }^{195}$ Marilena Chauí, Merleau-Ponty: a obra fecunda, acessado na internet.

${ }^{196}$ Referência a Cor, 7:156: E Minha Misericórdia abraça todas as coisas.

${ }^{197}$ A tradução deste termo é problemática. Traduzido habitualmente por "Ser" ou "existência", ele tem vastíssima aplicação na obra de Ibn 'Arabî. Ver a respeito: Chittick, W., The Sufi Path of Knowledge e "La Unidad del Ser", In: Postdata.

${ }^{198}$ Chittick, "La Unidad del Ser", p. 33.
} 


\subsection{RAZÃO ANALÓGICA, INTUIÇÃO ANALÓGICA}

Um menino, de 5 anos de idade, faz um desenho no qual predominam o amarelo e o laranja; ele nos diz que seu desenho se chama "o dia". Proponho-lhe, então, que desenhe a noite. Ele pára um instante, depois se vai. Volta com um desenho no qual predominam as cores verde, verde escuro, preto. Quando Ihe pergunto como fez isso, ele responde: eu penso.

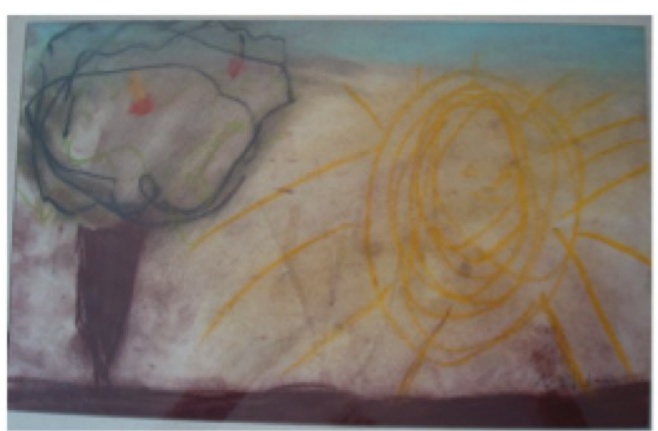

o dia

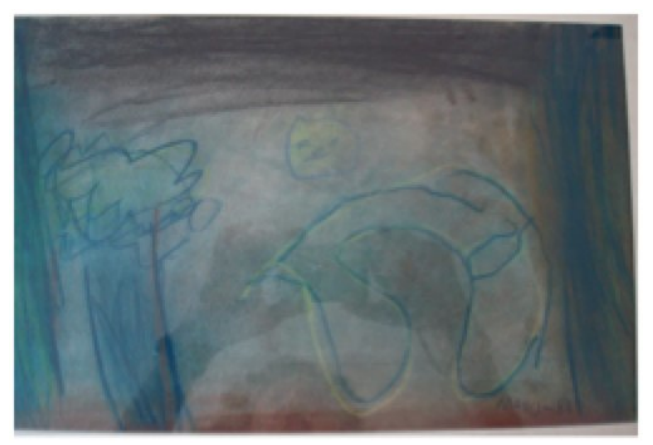

a noite

Um outro menino toca violão. Ele "tira" as músicas com facilidade, tem agilidade na mão direita para dedillhar as cordas, parece que ele "sente" as músicas pois seu corpo corresponde em gestos ao que ela é. Seu professor diz que ele tem um grande talento.

Então, proponho uma definição: talento é a capacidade de lidar com uma coisa qualquer como se ela fosse uma linguagem. Esses dois meninos fizeram traduções. O primeiro nunca estudou pintura, o segundo estava começando a ter aulas de violão. O que os diferencia dos outros meninos que tentam desenhar ou aprender violão? O fato de saberem traduzir uma realidade: o primeiro, concebeu, em seu espiritozinho de 5 anos de idade, que a 
relação do amarelo-laranja para com o verde-escuro é análoga à relação do dia para com a noite. Ele viu através dos materiais, viu relações, viu linguagem. O segundo sentiu com seu corpo - com suas mãos, seus dedos - relações dos sons entre si e sua analogia com as posições das cordas do violão. Ambos têm, inegavelmente, o que chamamos talento.

Dito de outro modo, talento é uma posição para aprender, isto é, estar diante de uma coisa como se ela fosse uma linguagem é poder dialogar com ela, isto é, experimentar, fazer tentativas, ir e vir, ensaiar, propor, descobrir, contactar, criticar, desvendar, conhecer, $i$ dentificar, desidentificar, errar, retomar, perseverar, ter paciência, lançar-se, assegurar-se, perder-se, numa palavra: aprender. É por essa razão, por exemplo, que um erro, no caso, não acarreta desânimo, ao contrário, ele se torna imediatamente informação porque há um todo por detrás.

"...é preciso olhar as notas na partitura para se saber onde tocá-las mas, para saber seu significado, é preciso olhar atrás das notas." (Vladimir Horowitz - pianista)

Só que isso não é feito por meio do pensamento ou de uma realidade mental qualquer. Isso é feito por meio do pensamento corporal, isto é, uma atitude interna de acoplamento. Ou seja, há algo harmônico dentro dessas crianças que ressoa fora, o diálogo não se deu entre o amarelo e o dia e sim entre a relação amarelo-dia/verde-noite. O acoplamento é uma espécie de vibração, de sintonia pelo harmônico, pelo que vibra junto.

Numa outra perspectiva, penso nesta florescente passagem de Merleau-Ponty como um processo entre linguagens.

"O sentido é o movimento total da fala, eis porque o pensamento arrasta-se na linguagem. Por isso, também ela o atravessa como o gesto ultrapassa seus pontos de passagem. No instante preciso em que sentimos o espírito repleto de linguagem, quando todos os pensamentos são tomados por sua vibração e justamente na medida em que nos abandonamos a ela, passa além dos signos para seu sentido. $E$, deste sentido, nada mais nos separa: a linguagem não pressupõe sua tábua de correspondências, ela mesma desvela seus segredos, ensina-os a qualquer criança que venha ao mundo, é toda mostração. Sua opacidade, sua obstinada referência a si mesma, suas voltas e redobros sobre si são precisamente o que faz dela um poder espiritual: com efeito, torna-se por sua vez algo como um universo, capaz de abrigar em si as próprias coisas, após tê-las mudado para seu sentido."199

Como observa Bateson ${ }^{200}$, o agricultor "sente" a chegada da hora da colheita por um processo analógico de contato com a terra. O que aqui também chamamos de acoplamento.

\footnotetext{
${ }^{199}$ Merleau-Ponty, A Linguagem indireta e as vozes do silêncio, op. cit., p. 144.

${ }^{200}$ Gregory Bateson, biólogo, um dos principais pensadores de Esalen, um centro educacional multidisciplinar na Califórnia, muito ativo no final dos anos 60.
} 
Um menino, andando na rua com sua mãe, viu um volkswagen todo amassado na frente: "Olha mãe, (apontando o carro) ele tá assim!" e franziu o rosto. Se o carro é análogo ao corpo, a frente é o rosto, os faróis, os olhos. Quem ensinou isso ao menino? Seu talento para pensar analogicamente, sua autonomia para transitar entre duas estruturas - pois, o carro e o corpo tornam-se estruturas para poder ser pensados analogicamente.

Retomo o exemplo utilizado no capítulo 1.4 para extrair dele mais implicações.

Uma criança chora. O que fazemos normalmente é pedir-lhe que pare de chorar e nos explique o que está acontecendo. Para corresponder ao nosso pedido, ela pode buscar alguma palavra de seu pequeno repertório e nos dizer, talvez, que está triste. No entanto, esta palavra torna presente muito pouco ou quase nada da experiência em si. Como resultado, perguntamos - como se isso pudesse trazer algum conhecimento - por que ela está triste, inserindo-a, assim, na cadeia causal da qual ela provavelmente jamais sairá. Ela nos dará alguma resposta que lhe pareça satisfatória. E nós tentaremos convencê-la a alegrarse, dizendo outras palavras do nosso repertório que lhe indiquem, talvez, que não há motivo real para tristeza, que faremos algo para eliminar a causa da tristeza ou que lhe daremos algo em compensação. Em todos os casos, estaremos implicitamente dizendo-lhe que não é bom que ela fique triste, que é bom fazer o possível para eliminar a tristeza.

Na semana seguinte, se ela chorar novamente, o processo se repetirá e todos acreditarão que há uma tristeza recorrente. Porque o nome é o mesmo, diremos que a experiência é a mesma.

Por outro lado, se lhe pedirmos que, em vez de dar um nome genérico para o seu sentimento, nos dê uma analogia dele, como por exemplo, "que bicho seria esse sentimento?" Ela diria, é uma minhoca de gravata que está muito brava e fala alemão enquanto come um bolo quentinho. E nós deixaremos que ela siga contando uma história do que está sentindo e pensando e a incentivaremos com perguntas. O que ela sente não ganha um nome, um rótulo vazio. Ganha uma história, uma travessia, uma situação analogicamente transmissível na linguagem verbal. Ganha, portanto, forma, realidade para o outro. Aquele sentimento que, muito provavelmente, pertencia à ordem da angústia, do indizível, do Mistério - e, por isso, não encontrava pouso na pobre, indigente realidade egóica - disfarça-se de fábula e penetra, com o seu manto de amplitudes, no ainda insípido mundo do imaginário infantil. O que, implicitamente, estamos lhe dizendo é que a angústia tem pouso, não precisa ser afastada, anestesiada, alijada.

E o que tecnicamente estamos lhe dizendo é que ela pode, pouco a pouco, com a utilização de um método analógico, ir construindo dentro de si os meios de escuta disso que está querendo ser dito e que se origina do seu lugar de ser singular. Isto é, que o método analógico permite uma articulação sempre atual entre a singularidade misteriosa e o diálogo com o Outro. Dito de outro modo, que o método analógico consiste na construção lenta e constante - da emancipação da singularidade por meio do diálogo direto com o Outro; porque o recurso analógico permite que as duas pontas invisíveis da realidade, o 
sujeito e o Outro, apareçam numa relação, portanto, se tornem visíveis numa atualidade, num momento, num lugar e para pessoas específicas.

Na semana seguinte, a criança chora. Mas, dessa vez, o sentimento que está acontecendo ali é a asinha de um pássaro que voou, voou prá muita lonjura e ficou cansada de tanto bater e falou pro pássaro que ele precisava fazer umas férias imediatas. A experiência é totalmente outra. Tudo variou, o momento é outro. E a criança não será obrigada a pensar: "estou sempre triste, há algo de errado comigo". Porque esta é uma construção imaginária que o modo habitual de tratarmos o ego lhe impõe: o modo no qual as palavras e as coisas, a despeito de Foucault e de toda a filosofia do séc. XX, ainda são tratadas como ligadas por uma relação de representação.

A diferença entre o choro minhoca e o choro asinha de pássaro não pode ser explicitada racionalmente, não pode ser cristalizada nem esgotada. Ela exige um trânsito, um passeio pelo conjunto de possibilidades que ela estabelece. Nesse passeio, é possível encontrar lugares, coisas não sabidas porque as relações não foram estancadas pela palavra/rótuloimaginário "triste".

Aqui surge uma noção importante: a de intuição analógica. No Sufismo, essa expressão não existe desse modo. Na verdade, há um sem número de termos - desvelamento ( $k a-$ shf), alusão sutil (isharât), inspiração (waridat), etc. - designando, cada um, aspectos diferentes do que, grosso modo, poderíamos chamar de intuição. Assim como os esquimós distinguem centenas de tonalidades do branco que, para nós, que não possuímos a mesma capacidade distintiva, aparece sempre sob uma única palavra "neve", podemos constituir essa palavra "intuição" para designar, provisoriamente, toda e qualquer experiência resultante do método analógico e que possua a característica de mostrar algo que ainda não tinha sido visto. Por outro lado, a tradição filosófica pensa a intuição de diversos modos, no entanto, não importa agora definir o termo e pensar com base na sua definição. 0 que estou buscando é, antes de tudo, ensaiar relações, fazer algumas experiências com as possibilidades do pensamento analógico.

A intuição analógica seria o re-arranjo do caleidoscópio, seria o aparecimento de uma nova possibilidade, de um novo jeito de ver, de um novo lugar, de uma outra posição relacional. Ela pode ser concebida como em diferentes graus ou amplitudes: no nível mais amplo, ela seria a mudança de Hamlet para Lawrence Olivier, no nível mais estreito, poderia ser um insight, num nível intermediário, seria, por exemplo, uma desidentificação com uma posição imaginária e a descoberta de uma outra.

Imaginemos uma situação a mais banal possível. Relato uma história que me contaram. Uma fisioterapeuta tinha que dar uma conferência. Ela nunca havia falado em público antes e estava muito aflita. Seu tema era referente a algo como "leitura corporal" e, ao iniciar sua fala, logo após os cumprimentos de praxe, ela se esqueceu totalmente do que pretendia dizer, como, de resto, acontece muito frequentemente em casos de muita ansiedade. Nesse momento, ocorreu-lhe uma saída e ela disse: "a leitura corporal é uma 
coisa muito simples, mais simples do que se pensa habitualmente, vejam vocês, por exemplo, as minhas pernas, elas estão tremendo, muito possivelmente isso traduz o meu nervosismo ao falar aqui diante de vocês". As pessoas riram e alguns manifestaram verbalmente seu apoio, disseram-lhe palavras de encorajamento e ela "relaxou" e pôde dar a sua conferência finalmente. De um modo muito simples, o que ela fez foi traduzir o seu estado anímico nos termos do conteúdo sobre o qual pretendia falar, isto é, a leitura corporal, de maneira não apenas a falar de algo mas, antes de tudo, para falar de si. Uma tradução analógica, bem entendido.

O que podemos supor com razoavel naturalidade é que, mais do que as palavras encorajadoras, o que permitiu a mudança de posição foi uma - modesta, limitada, porém, efetiva - auto-denúncia, uma explicitação pública de seu estado emocional, o que corresponde, ainda que modestamente, a uma denarcisação, uma necessária desidentificação do estado, o que lhe permitiu encontrar uma posição mais, por assim dizer, confortável.

Nesse caso, eu diria que ela intuiu uma saída, desde que se compreenda que não trata de uma intuição "ex nihilo", como se tende a pensar a intuição no senso comum, e sim o fruto de uma visão de uma analogia possível, com tudo o que ela implicava. E a banalidade da situação indica algo que me parece crucial: a intuição analógica transita por qualquer lugar, do mais simples ao mais complexo.

Uma imensa dificuldade desse tipo de enfoque reside na sua aparente semelhança com os discursos de uma certa psicologia americana, intrinsecamente focada no comportamento. Minha perspectiva não é essa. As considerações de Rogers sobre a pessoa contêm elementos, sob certos aspectos, úteis, porém a questão aqui tratada, em larga medida, ultrapassa a idéia de "pessoa". De Skinner à inteligência emocional, a distância é ainda maior. É verdade que uma "inteligência emocional", se pensada nos termos com que os sufis pensam o 'adab - a ciência islâmica da cortesia - é extremamente necessária. Mas o 'adab, sobre o qual falarei mais extensamente no capítulo 2.12 , é uma estrutra vazia cujos termos de referência estão baseados na denarcisação e na construção criativa do outro, sua intenção não é que as pessoas saibam comportar-se para evitar a desordem, o conflito e a rejeição por parte das figuras de autoridade, como é, em última análise, a "proposta" de Goleman $^{201}$.

Assim, no que se passa entre a minhoca e a asinha de pássaro, a criança pode surpreender-se com possibilidades suas que ela desconhecia, com lugares novos - portanto, capacidades, sentimentos, idéias, etc. de outra qualidade. Nesse passeio, as palavras são o que nasceram para ser: asas, canoa, caminho, passagem. Isto é, são sempre mais do que são, seu destino sendo o de transcender-se:

"Na estrada das Tabocas, uma vaca viajava. Vinha pelo meio do caminho como uma criatura cristã..." (J. Guimarães Rosa, Sequência, in Primeiras Estórias) ${ }^{202}$

\footnotetext{
${ }^{201}$ Sobre crítica à "inteligência emocional", ver Maria Helena Patto, Mutações do Cativeiro, op. cit.

202 Obras Completas, Vol. II, Ed. Nova Aguilar, Rio de Janeiro, 1995.
} 
A vaca que, como todo símbolo, leva o homem na direção do Misterioso, do milmaravilhoso, "transcendia ao que se destinava" (pg. 434). No meio do caminho, o lugar entre duas margens, dois opostos, está a vertical, a via reta, o entendimento que só a intuição propicia. Não estando na fixidez da margem, está no meio do rio, na terceira margem: a invisível, a incompreensível, a absurda terceira margem, para quem está do lado de cá.

Leio "A terceira margem do rio" 203 como um relato de perplexidade que desloca uma certa perspectiva "pós-desencantada" numa direção "encantada". Se, para Derrida, o outro alcançável-inalcançável se encontra na "margem adiante", no Sufismo, o outro, igualmente alcançável-inalcançável, encontra-se na margem entre, a terceira, a que era invisível antes que alguém pusesse uma canoa nela.

"A estranheza dessa verdade deu para estarrecer de todo a gente. Aquilo que não havia, acontecia."

"...todos pensaram de nosso pai a razão em que não queriam falar: doideira."

"...se desertava para outra sina de existir, perto e longe de sua família dele."

"A gente teve de se acostumar com aquilo. Às penas, que, com aquilo, a gente mesmo nunca se acostumou, em si, na verdade. Tiro por mim, que, no que queria, e no que não queria, só com nosso pai me achava: assunto que jogava para trás meus pensamentos."

"Não, de nosso pai não se podia ter esquecimento; e, se, por um pouco, a gente fazia que esquecia, era só para se despertar de novo, de repente, com a memória, no passo de outros sobressaltos."

"Nem queria saber de nós; não tinha afeto? Mas, por afeto mesmo, de respeito, sempre que às vezes me louvavam, por causa de algum meu bom procedimento, eu falava: - "Foi pai que um dia me ensinou a fazer assim..."; o que não era o certo, exato; mas, que era mentira por verdade."

Tão fluida quanto o rio e tão fixa quanto o pai, a terceira margem é feita desta certeza inimaginável entregue ao Deus-dará. O que Deus dá é esse súbito rompimento da cadeia estável de previsões do ego. É um ato falho ${ }^{204}$ que rompe o rio do discurso com o absurdo de uma significação inesperada, porque vinda do Possível e não do conhecido. Saída da verdade, não do saber.

Quando a gente está de fora, como estava o narrador da "Terceira Margem...", o desejo sem medida do outro, no caso, seu pai, parece fundamentalmente incompreensível: um

\footnotetext{
203 Idem, ibidem.

${ }^{204}$ Como o leitor pode notar, uso a expressão metaforicamente, portanto, "torcendo" mais uma vez o seu sentido psicanalítico original.
} 
barco, solitário, às margens do além. No entanto, é de dentro da canoa que a gente experimenta o que é viver au delà des rives gauches ou droites, au delà de la rivalité, para além do antagonismo, porque é o singular que não tem com quem medir-se. A terceira margem é esse lugar indecidível e sem pouso, lugar de leva sem rastro, conforme o sem forma da água, essa pura aceitação do discurso do rio: no entre-margens, o meio de si, a justa medida do que ultrapassa. É esse mesmo meio do caminho de que falou Dante, ao abrir sua Divina Comédia: "Nel mezzo del camin di nostra vita, in una selva oscura mi trovai...". A selva escura do desejo abriga os súbitos espectros do indizível. É sempre do outro lado que a gente entende, mas o outro lado não está em frente, está no meio, quer dizer, no lado além.

O Outro é um conjunto de possíveis. Mas é a singularidade que o desconstrói e re-propõe. O ego pode fazer um movimento mental de desconstrução, mas o exercício analógico pode levar a um movimento integral de re-arranjo, porque ele integra dimensões outras da realidade, porque ele trabalha a razão como linguagem.

Outro exemplo. Se um homem está fechado numa caverna escura, sem instrumentos e impossibilitado de ver o nascer do sol no leste, ele não pode estabelecer os pontos cardeais e não possui, portanto, orientação externa. No entanto, há uma direção que ele conhece necessariamente: a vertical. O conhecimento do eixo zênite-nadir, dado pela força gravitacional que ele sente em seu corpo, por meio de uma sensação, não pode não ser percebido e não depende de nenhum referencial externo, além do corpo - que, obviamente, não é externo. A percepção da vertical, na experiência e não no pensamento, não depende, portanto, de nada "fora". Não depende da biografia do sujeito, das condições climáticas, da história, da classe social, do país de origem, da língua falada, da saúde, do tempo ou do lugar. Ela, num certo aspecto muito preciso, exclui o Outro. A percepção da vertical está presente no corpo do sujeito desde o seu nascimento até sua morte. É a sua percepção mais perene e mais constante. É também a mais banal. Como tal, ela é análoga - e, por esse motivo, define sem definir - à singularidade, ao que se encontra na antípoda da alteridade, ao que é absurdo pois, como é possível pensar sem a alteridade?

A vertical é, nesta construção, o mistério singular posto pelo fato de que é o homem, este que possui linguagem, que inventa o Outro.

No espírito, a vertical pode chamar-se "intuição". Ao estabelecer uma analogia entre vertical e singularidade, eu não defini nem conceituei a singularidade, o que eu fiz foi expô-la a possíveis intuições. De fato, por definição, a singularidade não pode ser definida, ela só pode ser intuída. Assim, as relações estabelecidas numa analogia não são "um recorte", uma representação, muito menos uma verdade. Elas são uma forja propiciatória, um andaime, uma provocação.

Dito de outro modo, falar em dialogar com o Outro é falar em dialogar com a Lei simbólica. Isto significa olhar para a realidade como um conjunto de símbolos, sendo que a "definição" de símbolo que passo a utilizar por ora é: o que pode ser conhecido pelo sujeito a 
partir de um lugar singular. O método por excelência deste diálogo é o pensamento analógico.

"Se não fosse a borboleta, a lagarta teria razão?" pergunta-nos o mestre Guimarães Rosa. Podemos ler esta frase segundo os mais variados planos de realidade.

- num plano psicológico: a razão, então, em nós existe para que, em nós, desabroche nossa borboleta?

- num plano moral: os que rastejam, os apegados à terra, só têm razão pelos que voam?

- num plano, digamos, pragmático: o trabalho desta vida só tem razão em função da transformação que ele gerar?

- num plano filosófico: a imanência só tem razão pela transcendência?

E assim por diante. Em tese, nenhuma destas afirmações contradiz as outras e todas estão igualmente "contidas" como possibilidade na frase do Guimarães, de modo que nenhuma pode ser considerada mais verdadeira que a outra.

Além disso, a analogia entre elas torna-se evidente quando consideramos que cada uma respeita a estrutura da frase original.

Agora, se o número de leituras possíveis desta frase é indefinido, não necessariamente quem a criou estava "consciente" de todas elas. Claro está que, ao criá-la, Guimarães viu algo mais que um simples juízo, ele vislumbrou um conjunto de possibilidades, mas logo foi surpreendido por muitas outras. E quem quiser ler a frase, terá que fazer o mesmo.

Dito de outro modo, não é possível se estar consciente de um número indefinido de possibilidades, mas é possível vislumbrar algo como um eixo pelo qual perpassam essas possibilidades num relance, como um raio no céu.

Duas coisas são fundamentais aqui:

1) estas possibilidades não estão espalhadas aleatoriamente num espaço qualquer, elas são análogas, portanto, estão organizadas numa mesma estrutura. Esta estrutura também pode ser vista como um eixo vertical atravessado pelos diferentes planos de cada analogia;

2) conforme a qualidade deste vislumbre, temos diferentes tipos de intuição analógica e, em alguns casos, ela provoca apenas uma compreensão nova, em outros, uma mudança de posição imaginária, em outros ainda, uma mudança de posição simbólica (alteração de sintomas, de metáforas, etc.). Voltaremos a esses termos.

Consideremos o pensamento analógico como uma estrutura: 
1. um professor leva idéias aos alunos;

2. assim como um carteiro leva cartas aos seus destinatários.

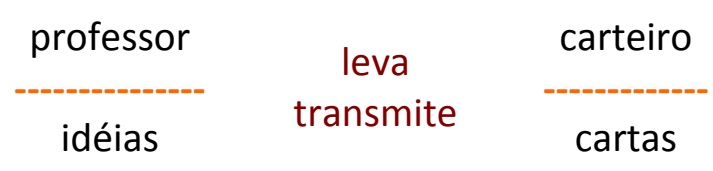

Podemos também dizer: o professor está para as idéias assim como o carteiro está para as cartas, o que permite ver com facilidade que a analogia segue a estrutura abaixo:

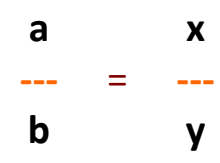

Ou seja, é a estrutura da proporção, cujo termo em latim é ratio. Pensando na obra de Ibn 'Arabî, esta razão é a faculdade que permite apreender o alâm al mițal, o mundo das analogias - como vimos, uma das definições de "realidade" para o mestre andaluz -, pois ela permite combinar diversos planos da realidade articulando ao mesmo tempo o particular e o universal ${ }^{205}$, o detalhe e o conjunto, o microcosmos (isto é, o sujeito) e o macrocosmos (isto é, o mundo, se pensarmos o macrocosmos como o visível, ou o Outro, se o pensarmos também como invisível).

"O Shayh al-Akbar estabelece uma vinculação entre a razão (al-'aql), o Nome divino "o Senhor" (al-Rabb), o Profeta Abrahão (Ibrahîm), o planeta Saturno (zuhul) e o "ardil de Deus" (makri Allâh).

Uma tradição no Islam considera que a Astrologia foi revelada a Abrahão, o "pai de uma multidão de nações" (Gênesis).

Saturno é o último planeta visível do Sistema Solar, sua órbita, portanto, "engloba" todas as outras. Ele aparece na cosmologia do Shay $\underline{\underline{h}}$ como a sétima esfera celeste, a que encerra este mundo.

Se a razão é o que ordena a partir de pontos de referência, é o que compara por meio de generalizações, é o que delimita e recorta, é o que "faz aparecer" por meio do equacionamento e do recorte, é o que explicita o que estava implícito, o que distingue leis, padrões, organicidade, sistemas, redes de relações, o que estabelece novas conexões, o que esquadrinha, enquadra, acreditamos poder defi-

\footnotetext{
205 Sendo que "universal" não quer dizer aquilo que pode ser imposto a todos porque é a única verdade. Quer dizer uma parte da construção que se refere ao "um e um para cada um", ao necessário aspecto totalizante do singular.
} 
ni-la como perfeitamente análoga ao conceito de estrutura, tal como o estivemos trabalhando até aqui. Razão seria, nesse caso, a faculdade que estabelece a sintaxe das transformações possíveis, o jogo de arranjos e desarranjos, a faculdade que funda a linguagem: aquilo que engloba, abarca e, como a esfera de Saturno, liga e separa o visível do invisível.

A razão seria o análogo "consciente" da estrutura. Pensemos no termo em latim, ratio, como proporção: temos uma proporção qualquer, por exemplo, a/b = x/y. Juntemos esta idéia com a analogia que fizemos acima: o sol / sistema solar = leão / floresta, isto é, o sol é o centro do sistema solar assim como o leão é o rei da floresta.

Desse modo, diremos, fazendo eco ao cognitivismo na psicologia: a analogia é a operação mais complexa e abrangente da razão. Ela é, portanto, o análogo "consciente" do simbólico.

O que estrutura todas as coisas, o que tudo comanda, o "pai de uma multidão de nações" é o planeta Saturno. Como o simbólico subjacente à existência, ele é o esqueleto de todas as formas, como fronteira entre o mundo visível e o invisível, ele é a pele que separa, distingue, filtra e comunica. Como a condição cósmica que dá origem a tudo o que existe, ele traduz em sua natureza a relação paradoxal e necessária entre o servo e seu Senhor, tudo o que está abaixo da sétima esfera é "servo" e os Nomes, que estão acima, são os "Senhores". Se não há linguagem, ou, se não há simbólico - portanto, sem "Saturno" -, o servo não serve ao Senhor, isto é, não o manifesta.

$B a r z a \underline{h}^{206}$ entre a Intuição e as outras faculdades, o Saturno-razão é o trabalho infindável de arar - de esquadrinhar, de estruturar - a terra para que a chuva da compreensão intuitiva dê seus frutos. Mas é preciso cuidado e alerta:

'É (...), deste céu - que é o da serenidade, da estabilidade - que procede paradoxalmente o "ardil divino" (makr, istidrâj). Mas este paradoxo é apenas aparente: a estabilidade fecha o que é aberto, limita o que é infinito. Ela é nada mais que uma enganação perigosa, a mais alta mas, a mais mortal das tentações. ${ }^{207}$

Eis aí a importância do caleidoscópio. A estabilidade trazida pela razão - na forma do equacionamento, do estabelecimento de um recorte, de um ângulo de abordagem - pode gerar uma estrutura fixa, um padrão. Sem abdicar do rigor da estruturação, é necessário, então, que o movimento esteja sempre garantido, que, a cada momento, um novo mundo se crie, um novo equacionamento, uma nova cosmologia, um novo universo linguístico. A razão, portanto, no homem, não é o que "comanda" mas é o que se submete ao que a renova. A razão-serva do seu Senhor é a única defesa contra o "ardil" de Deus.

\footnotetext{
${ }^{206}$ Ver na página 195 a explicação desse termo.

${ }^{207}$ Chodkiewicz, Le Sceau, op. cit., p. 208.
} 
'O mundo inteiro é a forma exterior da Razão Universal,

Pois esta é o pai de todas as criaturas racionais.

Quando um homem age com ignomínia para com a Razão Universal,

Sua forma, o mundo, mostra-lhe os dentes.

Sê leal para com este pai e renuncia à desobediência,

Para que essa casa terrena te possa fornecer tapetes dourados.

Então, o Dia do Juízo será o "pagamento de tua condição";

A terra e os céus serão transfigurados diante de ti (Cor, 14:48).

Estou sempre em harmonia com esse nosso pai,

E a terra sempre me aparece como um Paraíso.

A cada momento, uma nova forma, uma nova beleza,

De modo que o tédio desaparece ante essas visões sempre frescas.

Vejo o mundo cheio de bençãos,

Água fresca sempre a brotar de novas fontes.(...) $)^{208}$

Esta razão-serva, submissa, portanto, não rígida e nem estável, mas estruturada e maleável, é a faculdade "caleidoscópica" do sujeito, sua capacidade simbólica."209

Assim sendo, essa estrutura contém múltiplas possibilidades mas não são possibilidades quaisquer, são aquelas que permitem articular realidades muito diferentes, a saber, a realidade "visível" de um conjunto e a realidade "invisível" do sujeito.

Dito de outro modo, a organização analógica, como vimos no caso da menina chorando, "dá fala" ao sujeito em seu diálogo com o Outro.

Quando aramos a terra e chove, surge o broto. Se chove e não aramos a terra, não surge nada. Se aramos a terra e não chove, tampouco surge alguma coisa.

O método analógico é um modo de tratamento da razão como linguagem.

A terra arada está para a razão assim como a chuva está para a intuição, se aramos a terra, isto é, se construímos uma analogia, a chuva da intuição pode vir ou não, mas, se ela vier, encontrará pouso porque a analogia é uma estrutura de sustentação da intuição que é um tipo de significação particular, isto é, é uma significação inesgotável.

Assim,

1. se houver uma elaboração racional (pensada aqui como analogia) e não houver uma intuição (analógica), não adianta nada, isto é, não há re-arranjo, não há descoberta nem invenção.

2. se não houver uma elaboração racional e houver uma intuição, também não adianta

\footnotetext{
${ }^{208}$ Rumi, Masnavi, op. cit., p. 258.

${ }^{209}$ Sentidos..., op. cit. pp. 249-51.
} 
nada, isto é, há como que um ato falho deixado a si próprio, um re-arranjo que não se põe de fato, em alguns casos, um desejo sem fala ou uma angústia.

3. para que haja frutos, é preciso:

a) trabalhar racionalmente a questão

b) e esperar a intuição que trará a dimensão singular da questão.

Assim sendo, a razão está para a intuição, assim como a terra arada está para a chuva.

Construindo a metáfora: a intuição é como a chuva para o campo fértil da razão.

Ou simplesmente, a intuição é a chuva do campo fértil da razão. Daí a frase de Adélia Prado: "A metáfora é a guardiã da realidade".

$\begin{array}{ccc}\text { razão } & \text { terra } \\ \text { intuição } & = & \text {----------- }\end{array}$

Em uma outra estrutura metafórica, temos:

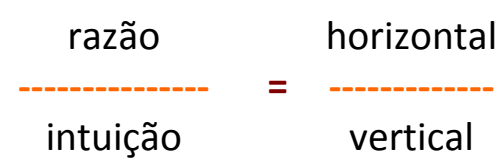

E numa outra ainda:

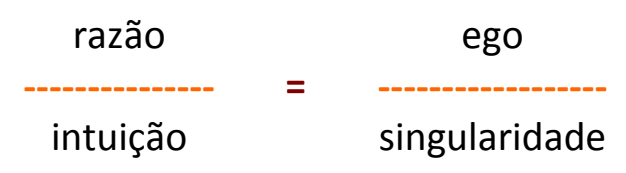

A razão pode ser vista como análoga à horizontal por meio, por exemplo, da estrutura das direções do espaço: se o par zênite e nadir corresponde à vertical, a horizontal, formada pelos 4 pontos cardeais, é o que fornece os referenciais na terra, isto é, numa terminologia medieval, trata-se do mundo sensível, numa terminologia atual, trata-se dos referenciais que definem uma linguagem qualquer, uma estrutura qualquer, um discurso qualquer, enfim, qualquer conjunto de relações. 
Numa outra perspectiva, temos:

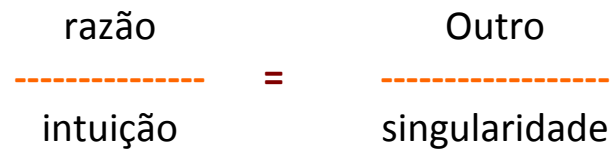

Girando o caleidoscópio, podemos ter infindáveis jogos de relações analógicas entre estes termos, de modo que eles não constituem uma estrutura fixa nem centrada. E cada um desses giros expõe ou desvela um ângulo diverso da questão: a razão não é sinônimo do Outro, nem do ego, nem da horizontal, nem da terra. Mas cada um ajuda a mostrar algo do outro.

Na perspectiva que estamos construindo, a intuição fica sendo a vertical e a razão, a horizontal $^{210}$.

Como foi dito antes, deve-se admitir que há vários graus de intuição, desde aquela que resulta de um vislumbre de possibilidades, até aquela que opera uma renovação singular no sujeito.

Esta renovação pode, simplificadamente falando, dar-se em duas vias:

a) a organização analógica "revela" ao sujeito algo dele mesmo que ele não sabia porque ainda não havia tomado forma nem letra;

b) a organização analógica revela ao sujeito um jeito de ver as coisas que ele ainda não tinha experimentado;

Como o "jeito de ver as coisas" depende do lugar em que se está, a metáfora revela ao sujeito um outro lugar. Assim temos que a metáfora leva o sujeito a experimentar não novos pontos de vista "objetivos", mas sim novos lugares nos quais ele contempla ao mesmo tempo a si próprio e ao mundo de um modo renovado ${ }^{211}$.

\footnotetext{
${ }^{210}$ Como pitagóricos, geômetras platônicos, taoístas, brâhmanes, shamãs, antigos judeus, antigos cristãos e antigos muçulmanos, estamos diante do simbolismo da cruz, tão eloquente em tempos remotos e tão vulgarizado pelo sentimentalismo religioso por nós conhecido.

${ }^{211} \mathrm{O}$ senso comum atual vive uma diferenciação irredutível - criticada, é claro, pela Filosofia - entre sujeito e objeto, entre "interno" e "externo" que torna esta explicação mais árdua do que ela poderia ser. A rigor, se estamos aqui concebendo o conhecimento como a vertical que atravessa todos os planos de realidade, o conhecimento da interioridade é um plano, o da exterioridade é outro e o do coração do sujeito, sua singularidade misteriosa, é outro. São, portanto, três planos da mesma verdade ou são a mesma coisa em planos
} 
O "lugar vertical" é, então, aquele lugar no qual o sujeito encontra algo que ele não sabia. Em linguagem encantada, trata-se de algo que somente Deus, o Real (al- $\underline{H} a q q$ ) pode ensinar ao homem.

"Lê, em nome de teu Senhor que criou, que criou o homem de uma aderência. Lê! Teu Senhor é o Muito Nobre, que ensinou pelo cálamo, ensinou ao homem o que ele não sabia." (Corão, 96:1-5)

Nos termos da reflexão que estou propondo, trata-se de algo cuja fonte é a singularidade do sujeito. Agora, este verso corânico, que é o primeiro verso revelado a Muhammad, também pode ter a seguinte tradução:

"Lê, em nome de teu Senhor que criou, que criou o homem de uma aderência. Lê! Teu Senhor é o Muito Nobre, que ensinou a escrita, ensinou ao homem o que ele não sabia." (Corão, 96:1-5)

Na primeira tradução, respeita-se a imagem - "ensinou pelo cálamo" - na segunda, o que se traduz é o sentido - "ensinou a escrita". No mesmo verso, temos a articulação entre a vertical (cálamo) e a horizontal (escrita). A escrita é a horizontal, como vimos, porque é diferença. O cálamo aparece como a vertical por meio de diversos simbolismos tradicionais, entre eles o hadit: "A primeira coisa que Deus criou foi o intelecto ou o cálamo". Na tradição islâmica, Deus criou o cálamo - simbolizado pela letra álif ( 1 ), a primeira do alfabeto - e com ele escreveu a Criação nas "tábuas guardadas" (lawh mahfûz), isto é, o cálamo é o que marca e as tábuas são o que recebe a marca.

Ao mesmo tempo e no mesmo lugar, este verso nos diz que o homem pôde aprender o que ele não sabia graças tanto à vertical quanto à horizontal, tanto ao intelecto quanto à escrita. Portanto, a Origem, aqui, é tanto o logos ${ }^{212}$ quanto a escrita. Eis a "escrita geral" tal como concebida pelo Encantamento: presença e ausência, unidade e multiplicidade, identidade e alteridade, marca e re-escrita.

\footnotetext{
diferentes. Conhecer intuitivamente um é conhecer os outros.

212 Esclarecendo: numa conversa explícita com Derrida, remeto a uma possível analogia entre duas relações: $1^{\text {a }}$ o cálamo e a escrita, $2^{\text {a }}$ o logos e a escrita. Com isso não estou dizendo que haja igualdade entre o cálamo e o logos ou entre a escrita corânica e a escrita derridiana.
} 


\subsection{O SIMBÓLICO COMO ESTRUTURALIDADE}

O simbólico é a cruz do cálamo com a escrita, da presença com a ausência, do singular e do atual com a alteridade e o virtual. Para atravessar esta questão, pensemos, inicialmente, a questão da estruturalidade. O simbólico é, para aquilo que, sinteticamente, chamamos de realidade, o que a singularidade é para o homem. Cinco exemplos.

\section{UMA EQUAÇÃO DO SEGUNDO GRAU: $2 x^{2}+3 x-6=y$}

Aqui, temos que a equação é fixa, o "x" varia e o " $y$ " varia em função da variação do "x" na equação. Nesse caso, direi que a estruturalidade da equação reside nessa combinação específica de "fixo" e "mutável". A sua estruturalidade ${ }^{213}$ pode, então, ser análoga à razão, os valores possíveis para " $x$ " são possibilidades quaisquer mas, o "x" em si mesmo é imprevisto.

\section{A FRASE DE GUIMARÃES ROSA, QUE VIMOS ANTERIORMENTE SOB OUTRO PRISMA: "SE NÃO FOSSE A BORBOLETA, A LAGARTA TERIA RAZÃO?"}

Ela permite uma relação análoga com a equação acima. Note-se que Guimarães não diz: "a lagarta teria razão de ser?", o que tornaria a frase "fechada" e limitaria a metáfora. Ao dizer "razão" e, desse modo, propor uma analogia entre a lagarta e a razão, a borboleta, numa dualidade operativa, "torna-se" a intuição. Agora, examinando a estruturalidade desta "equação", temos, por exemplo, o seguinte:

- se não fosse o prazer,

\footnotetext{
${ }^{213}$ Tomo este termo na acepção com que Derrida o utilizou para questionar o centramento da estrutura. Se, para a Mística, a estrutura não pode possuir um centro fixo, o que a coloca à margem da tradição filosófica criticada por Derrida, o que estou discutindo aqui é justamente a articulação entre a "fixidez", que permite que a estrutura se ponha como tal, e a sua "mobilidade", que permite a variação e o descentramento.
} 
- o esforço teria razão?

- se não fosse a casa,

- a porta teria razão?

- se não fosse a arte,

- a comida teria razão?

- se não fosse a mulher,

- o homem teria razão?

Ou seja, mantemos a estrutura da frase e substituímos apenas os substantivos. Abre-se para um campo imenso de possibilidades de leitura da frase. O diálogo com a frase - ou a suplementação no sentido derridiano do termo - torna-se inesgotável. Mas, note-se, há uma estrutura que ordena as significações possíveis, há uma relação que faz com que os substantivos se tornem análogos entre si e que sugere relações de todos com a intuição e a razão.

Note-se também que, na última substituição, o par homem e mulher mostra o quanto os substantivos podem, na realidade, ser intercambiáveis e, nesse caso, podemos fazer o exercício de inverter todos os termos para ver as alterações de sentido que isso promove.

Essa estrutura é totalmente descentrada. É uma cartola de mágico.

\section{3. "AS MENINAS" DO VELÁZQUEZ}

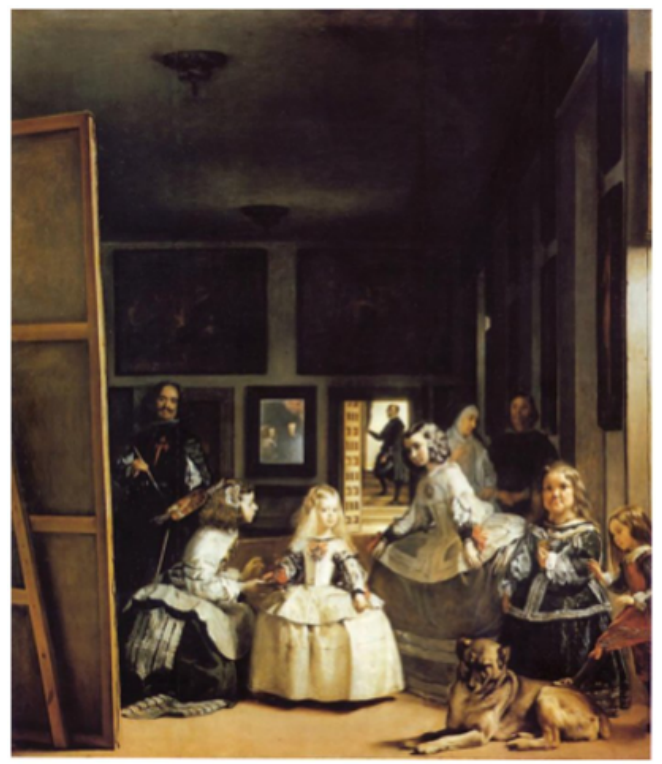

"Aparentemente, este lugar é simples; de pura reciprocidade: olhamos um quadro de onde um pintor, por sua vez, nos contempla. Nada além de um face a face, apenas olhos que se surpreendem, olhares diretos que, cruzando-se, superpõem-se. E, no entanto, esta fina linha de visibilidade em contrapartida envolve toda uma rede complexa de incertezas, de trocas e de esquivações. O pintor nos dirige seus olhos apenas na medida em que nos encontramos no lugar de seu modelo. Nós, os espectadores, estamos a mais. Acolhidos sob este olhar, somos excluídos por ele, substituídos pelo que, desde sempre, lá estava antes de nós: o próprio modelo. Mas, inversamente, o olhar do pintor dirigido para fora do quadro ao vazio que lhe faz face aceita tantos modelos quantos lhe vêm de espectadores; neste lugar preciso, mas indiferente, o olhante e o olhado substituem-se sem cessar." 214

\footnotetext{
${ }^{214}$ Foucault, Les Mots et les choses, op. cit., p. 20.
} 
Como nas estruturas anteriores, temos uma relação análoga entre o "fixo" e o "mutável": a pintura é fixa mas o contemplador, que está dentro e fora da pintura, varia interminavelmente, hora após hora, entre todos os visitantes do Reina Sofia em Madrid.

Ao inserir o contemplador na obra, a presença viva e cambiante surge na impassibilidade da marca pintada, a renovação é garantida pela estrutura, o quadro respira. E é o pintor quem o faz, com seu olhar de inventor, respirar.

Esta marca chamada "olhar do pintor", posta na escrita do quadro e na linguagem da pintura, inaugura, inventa e emancipa o lugar de revelação do contemplador, obrigando-o a, por sua vez, desvestir-se de sua vigília para entrar numa dimensão onírica que o põe em outro mundo possível. Ele não é convidado a entrar, tampouco é sugado por um portal como num filme de ficção científica. Como em toda marca, ele se vê dentro do quadro porque ali ele sempre esteve.

\section{TECENDO A MANHÃ, DE JOÃO CABRAL}

Um galo sozinho não tece uma manhã:

ele precisará sempre de outros galos. De um que apanhe este grito que ele e o lance a outro; de um outro galo que apanhe o grito que um galo antes e o lance a outro; e de outros galos que com muitos outros galos se cruzem os fios de sol de seus gritos de galo, para que a manhã, desde uma teia tênue, se vá tecendo, entre todos os galos.

E se encorpando em tela, entre todos, se erguendo tenda, onde entrem todos, se entretendendo para todos, no toldo (a manhã) que plana livre de armação. A manhã, toldo de um tecido tão aéreo que, tecido, se eleva por si: luz balão. (João Cabral de Melo Neto - poeta)

As pessoas de pouca fé supõem que amanhece porque o sol desperta no leste, mas o relato de João Cabral nos prova - porque nos faz provar - que, não fossem os gritos dos galos, nada sairia como previsto. Assim é também em outros campos: não fossem os atos da reflexão dos homens, compartilhados entre todos como louvor ao tecido da vida, e o sol da Graça e sua poderosa aurora não poderiam fazer o dia planar, livre de armação. 


\section{A MÚSICA "CONSTRUÇÃO" DE CHICO BUARQUE}

Novamente, uma estrutura análoga. As frases do poema se mantêm enquanto as proparoxítonas do final vão sendo alternadas a cada repetição do poema:

\begin{tabular}{l|l|l|l} 
amou daquela vez como se fosse & a última & o último & máquina \\
beijou sua mulher como se fosse & a última & a única & lógico \\
e cada filho seu como se fosse & o único & o pródigo & \\
e atravessou a rua com seu passo & tímido & bêbado & \\
subiu a construção como se fosse & máquina & sólido & \\
ergueu no patamar quatro paredes & sólidas & mágicas & flácidas \\
tijolo com tijolo num desenho & mágico & lógico & \\
seus olhos embotados de cimento e & lágrima & tráfego & \\
sentou prá descansar como se fosse & sábado & um príncipe & um pássaro \\
comeu feijão com arroz como se fosse & um príncipe & o máximo & \\
bebeu e soluçou como se fosse & um náufrago & máquina & \\
dançou e gargalhou como se ouvisse & música & o próximo & \\
e tropeçou no céu como se fosse & um bêbado & música & \\
e flutuou no ar como se fosse & um pássaro & sábado & um príncipe \\
e se acabou no chão feito um pacote & flácido & tímido & bêbado \\
agonizou no meio do passeio & público & náufrago & \\
morreu na contramão atrapalhando & o tráfego & o público & o sábado
\end{tabular}

Como ocorre nas estruturas anteriores, as significações estão condicionadas à estrutura pré-estabelecida e, ao mesmo tempo, abrem-se a uma variação que suplementa e transborda a estrutura. Nesse caso específico, há uma suplementação tanto de dramaticidade quanto de ironia e crítica. A cada novo substantivo, um aspecto mais interno surge como que revelando a gravidade da condição do operário-trabalhador capturado na estrutura centrada e hierárquica da construção que o empareda.

"... beijou sua mulher como se fosse lógico

e flutuou no ar como se fosse um príncipe

e se acabou no chão feito um pacote bêbado

morreu na contramão atrapalhando o sábado"

O salto entre "seus olhos embotados de cimento e lágrima" e "seus olhos embotados de cimento e tráfego" ou entre "sentou prá descansar como se fosse sábado" e "sentou prá descansar como se fosse um pássaro", além de ser uma passagem da frase literal para a metafórica, é um salto para uma surpresa. O "sentou prá descansar como se fosse um pássaro" não faz sentido fora do contexto.

O "como se" da estrutura é uma das chaves da estruturalidade. Ele inaugura a possibilidade de que algo ocupe o lugar de outro. Algo se põe como se fosse outro.

A perfeição (al-ihssân) consiste em adorar Allâh como se tu O visses, pois, se tu 
não O vês, Ele te vê. ${ }^{215}$

Para Ibn 'Arabî, este como se é a referência escriturária que inaugura o âlam al-hayâl, o mundo da imaginação. A imaginação, em Ibn 'Arabî, é descrita, entre outras formas, como um órgão e como um lugar.

O que é o cosmos, então? É o "outro" (gayr) já que se define como "tudo o que é outro que Deus". Mas não é o outro em todos os sentidos, já que é a totalidade das palavras articuladas no Hálito do Misericordioso, e o Hálito não é completamente diferente Daquele que respira. Ou, em outras palavras, o cosmos é a "revelação" (tajallî) de Deus em seus lugares de manifestação. Por meio do cosmos, o wujûd ${ }^{216}$ mostra suas características e suas propriedades, quer dizer, seus nomes universais e particulares, tanto os 99 Nomes de Deus como as entidades imutáveis. Portanto, o Hálito do Misericordioso translada as realidades invisíveis e inexistentes ao plano visível e existente.

Num sentido, o universo é outro que Deus, já que a essência de Deus está infinitamente além. Em outro sentido, o universo é idêntico a Deus, já que não há nada no universo que não $O$ nomeie. As palavras inesgotáveis pronunciadas por Deus são iguais ao Hálito e o Hálito é o mesmo que o Misericordioso. Portanto, as palavras são o mesmo que o Misericordioso. O $\underline{\underline{S}} a y \underline{\underline{h}}$ se desloca constantemente entre os dois pontos de vista, de identidade e diferença. Resume sua posição com a afirmação enganosamente simples "Ele/não Ele" (huwa lâ huwa). Cada entidade do cosmos é idêntica ao wujûd e, ao mesmo tempo, diferente do wujûd.

A melhor forma de entender a realidade do "Ele/não Ele" é por meio do conceito

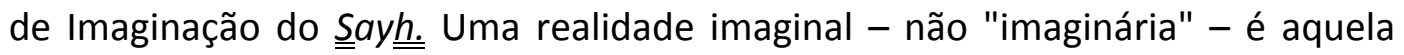
que reside num domínio intermediário entre duas outras realidades, compartiIhando atributos de ambos os lados. Uma coisa imaginal é o mesmo que cada um dos dois lados que a definem, ao mesmo tempo em que é distinta de ambos. Assim, pois, necessitamos afirmar tanto sua identidade com outras coisas como sua diferença delas.

Um exemplo comum de uma realidade imaginal é a imagem do espelho, que serve de ponte ou "istmo" (barzah $)^{217}$ entre o objeto refletido e o espelho. Temos que afirmar que a imagem é o mesmo que o espelho e, ao mesmo tempo, diferente dele, ou que não é idêntica nem a um, nem a outro. De um modo análogo, os sonhos constituem realidades imaginais. Se alguém vê seu pai num sonho, viu seu pai e não sua mãe ou sua irmã; ao mesmo tempo, o que viu não é outra coisa que ele mesmo. A realidade imaginal percebida é um istmo entre ele e seu pai. A afirmação mais sucinta que se pode formular com respeito à imagem do sonho é

\footnotetext{
215 Buhârî, tafsîr, s. 31; Îmân, 37, cit e trad. por Chodkiewicz, in Océan, p. 194, n. 10.

${ }^{216}$ A tradução deste termo é problemática. Traduzido habitualmente por "Ser" ou "existência", ele tem vastíssima aplicação na obra de Ibn 'Arabî. Ver a respeito: Chittick, W., The Sufi Path of Knowledge e "La Unidad del Ser", In: Postdata.

${ }^{217}$ Ver explicação do termo na p. 174.
} 
"ele/não ele". 218

Este simbólico que, como presença, é o 'alâm al-ḩhayâl - "mundo imaginal", conforme a bem recebida tradução de Corbin - resulta do "resto da argila de Adão" e, segundo Ibn 'Arabî, é designado no Corão como "a vasta terra de Deus" (4:97, 29:56, 39:10).

Participando da natureza de Adão, esta "terra", como ele, contém todas as realidades superiores e inferiores; como ele, é contígua ao mesmo tempo ao céu e à terra. Não maior do que "um grão de gergelim", ela é, como ele, um microcosmos; e no entanto o Trono, o Pedestal, os sete céus estão nela "como um anel jogado no deserto". Ela é "o teatro das visões dos gnósticos": se ela não existisse "seria impossível haver encontros a meio-caminho (munâzalât) entre nós e Deus; seria impossível que Deus [como afirma um hadît] "desça ao céu deste baixo mundo", que esteja "sentado no Trono" (Cor, 7:54). Mais genericamente, não fosse essa terra, os corpos e os espíritos jamais se encontrariam. ${ }^{219}$

Como parte do diálogo entre Ibn 'Arabî e algumas formas do pensamento contemporâneo, chamei o mundo imaginal (âlam al-hayâll) de simbólico.

No simbólico, todas as linguagens se entrelaçam caleidoscopicamente e inesgotavelmente. $\mathrm{E}$ a intuição é um trânsito por diferentes formações discursivas. Deslocando-se pelo simbólico, os homens estão vivendo relações de qualquer ordem ou tipo. Dialoga-se no deserto com Abrahão, com um mestre ou um antepassado morto e com as asas do por$\operatorname{vir}^{220}$. Não há indivíduos, não há identidade, não há forma cristalizada. Um homem pode ser outro, um homem pode ser Muhammad ou Jesus ou Maria, um homem pode ser pedra. E um homem, basicamente, não existe. O que há são lugares de manifestação. $O$ simbólico é a realidade que os homens encontram depois da morte e, por esse motivo, o Profeta recomendou aos seus companheiros: "Morram antes de morrer".

O simbólico é esse lugar de plasticidade no qual os homens podem tornar-se a matéria prima das representações de Deus. Ele é plástico no tempo, plástico no espaço e plástico no ser.

"... pois o homem não se dá conta espontaneamente do que não é e do que é de novo a cada 'sopro'. E se digo 'de novo', não estou supondo nenhum intervalo temporal, mas uma sucessão puramente lógica. Na 'renovação da criação a cada sopro', o instante de aniquilamento coincide com o instante da manifestação do semelhante (matal)."221

Difícil de conceber, esta radical plasticidade do mundo afirma que cada "coisa" existente está em constante recriação a cada instante, sem intervalo de tempo, como a projeção dos quadros de um filme de celulóide numa tela faz crer um

\footnotetext{
${ }^{218}$ Chittick, "La Unidad del Ser", in Postdata, p. 37.

${ }^{219}$ Chodkiewicz, Illuninations, p. 58.

${ }^{220}$ Não é preciso dizer que não se trata aqui nem de espiritismo nem de previsão do futuro.

${ }^{221}$ Ibn 'Arabî, Sagesse, p. 152.
} 
movimento contínuo.

A vida, como uma corrente de água, é sempre renovada, embora revista-se de uma aparência de continuidade em sua forma.

Esta aparente continuidade resulta de sua rápida renovação, como uma brasa quando é girada rapidamente.

Se um único fragmento de brasa é girado em velocidade, parece ao olho uma linha contínua de fogo;

essa aparente extensão, causada pelo movimento acelerado, demonstra a rapidez com que é movido. ${ }^{222}$

Ibn 'Arabî explica esta idéia com o exemplo do transporte do trono da Rainha de Sabah.

...[Salomão disse aos seus:] Ó Senhores! quem, dentre vós, me trará o trono [da rainha de Sabah]...? - Eu, respondeu um Afrit entre os gênios, eu o trarei a ti antes que te levantes de teu lugar. Sou bastante forte para isso, e fiel. - Aquele que tinha a ciência do Livro [grifo nosso] [disse a Salomão]: eu o trarei a ti antes que teu olhar se volte para ti (...). ${ }^{223}$

Ibn 'Arabî explica que o movimento pelo qual o olhar se volta para si mesmo possui a duração do instante, isto é, é imediato, à diferença do movimento de levantar-se do lugar, mencionado pelo Afrit.

...no mesmo instante em que Açaf ibn Barhiyâ falava da coisa, sua operação se realizou e Salomão viu o trono de Bilqîs "diante de si" (...) Ora, não existe, neste mundo, deslocamento na instantaneidade, mas o desaparecimento do trono e sua remanifestação operou-se de um modo do qual só tem consciência aquele que o conhece. ${ }^{224}$

Ou seja, o trono da rainha não foi transportado e sim "remanifestado", pois, se a cada instante um "semelhante" (ou análogo) é substituído por outro, basta que quem conhece esta ciência faça com que o semelhante se manifeste em outro lugar.

(...) A história da retirada do trono de Bilqîs é uma das histórias mais perturbadoras [do Corão], a não ser para aqueles que conhecem a realidade à qual fazemos alusão. (...) O trono não foi, portanto, transportado através do espaço, e seu deslocamento não aboliu a condição espacial, se se compreende bem o que estamos dizendo. $^{225}$

Pela respiração, o corpo se renova a cada instante. $\mathrm{O}$ ato mais básico, sem o qual não há a vida humana mais elementar, é também o ato mais constante, mais repetido e mais discontínuo. A cada momento, é preciso renovar a vida, chamá-la novamente, recriá-la. Ao mesmo tempo, "...a cada dia, Ele se ocupa de uma [nova] obra." (Cor, 55:29). Tudo está em movimento, a cada momento, algo novo se atualiza. No coração singular do homem, a respiração é harmônica com a pulsação do mundo e seu movimento aberto ao refazer-se.

\footnotetext{
${ }^{222}$ Rumî, Masnavi, p. 41.

${ }^{223}$ Corão, 27:38-40, cit e trad. por Burckhardt, in Sagesse, p. 151, nota 1.

${ }^{224}$ Ibn 'Arabî, Sagesse, p. 151-52.

${ }^{225}$ Ibn 'Arabî, Sagesse, p. 153.
} 
Porém, o simbólico, de fato, não é acessível ao homem "vivo", atado pelo ego à identificação com posições imaginárias, a não ser indiretamente. Mas, ele está aí.

Na perspectiva em que me coloco, o simbólico não se dá a ver, como para Lacan, na ciência ou na autoridade. A aliança que os casais colocam no dedo ao "selar sua união", a bandeira que representa uma nação, a própria nação, o logotipo de um produto de consumo, as flores que colocamos no cemitério no dia 2 de novembro, as palavras e as coisas, o futebol e o carnaval, a declaração dos direitos do homem, as histórias que encerram uma moral, nada disso é simbólico. São formas imaginárias da cultura de massas, são formas da ideologia burguesa, formas convencionais, formas representativas, não possuem nenhuma relação com a singularidade. O símbolo não é o veículo de uma idéia. A Psicanálise resgatou alguns de seus aspectos mas, nenhuma empresa espera que um candidato a um emprego coloque em seu curriculum os sonhos de suas últimas noites. Nenhum educador pode avaliar "o inconsciente" do aluno. O simbólico foi recalcado no mundo desencantado. Mas, ele está aí. Se não estiver, penso, não há como falar em autonomia.

A autonomia sendo, como vimos, o diálogo com o Outro naquilo que ele possui de Lei, diálogo solitário, feito de decisões solitárias, como a decisão que o menino de 5 anos tomou, depois de pensar: "farei a noite deste modo".

A construção dessa autonomia - um dos modos da razão de ser da educação - não pode ser egóica. A autonomia egóica, a chamada consciência dos deveres e direitos do cidadão, situa o sujeito na esfera jurídica como se ela fosse a única constituinte do espaço público, como mostra Habermas ${ }^{226}$, o que representa um recalque da sua dimensão simbólica e põe o sujeito diante de um "saber que sobrepaira", para reler Merleau-Ponty, isto é, de algo que é independente de uma construção feita na relação com o sujeito.

Além disso, simbolicamente, a autonomia não pertence a um sujeito. O símbolo é um objeto de transmissão em múltiplos níveis. Na Mística, ele alcança dimensões fora do escopo deste trabalho, mas, pensando com algumas de suas ferramentas, o símbolo permite uma transmissão que ultrapassa o texto vigente. Ele estabelece uma conexão entre sujeitos de um tempo a outro.

Para que um símbolo cumpra uma função que ultrapasse o texto vigente, é preciso que algumas condições estejam presentes. Historicamente, a Modernidade operou uma transformação tão profunda que este símbolo praticamente deixou de existir. No mundo encantado, os contos da tradição oral, certos monumentos, certos túmulos de santos, certos objetos faziam parte de um material simbólico que se opunha à fixidez dos dogmas. Com o Desencantamento do mundo, boa parte desse material passou à condição de "crendice" e perdeu sua função simbólica quando os homens, na observação de Walter Benjamin, deixaram de situar-se no cosmos para ter a cidade como referência. Não obstante, a transmissão simbólica subsiste: pais sempre educaram seus filhos por meio da palavra e

${ }^{226}$ Mudança estrutural na esfera pública, op. cit. 
isso sempre implica em dizer mais do que foi dito. A primeira idéia do simbólico é esse transbordamento de significação próprio de qualquer linguagem. A construção simbólica de um sujeito o faz transmissor singular desse transbordamento, mas, para ser transmissor, o sujeito também fala a linguagem de seu tempo, o que define seu assujeitamento a um tempo, um lugar e um grupo de pessoas. Assim, pais educam seus filhos para pertencer a uma classe social, funcionar corretamente dentro de uma ideologia e cumprir as demandas da proposta narcísica que lhes é feita. Mas também educam para além disso, ainda que não o saibam ou que o façam de um lugar em que não podem percebê-lo.

"Um mercador mantinha um pássaro numa gaiola. Estando de partida para a Índia, país natal do pássaro, perguntou-lhe se queria algo de lá. O pássaro lhe pediu sua liberdade, mas esta lhe foi negada. Então, solicitou ao mercador que fosse a uma floresta na Índia e que anunciasse seu cativeiro aos pássaros livres que ali se encontrassem.

O mercador assim fez e, mal se referira ao seu cativo, um pássaro selvagem semelhante ao que ele mantinha na gaiola caiu ao chão da árvore onde pousara, sem sentidos.

Pensando que o pássaro fosse parente de seu canário engaiolado, o mercador ficou pesaroso por ter sido o causador daquela morte.

Regressou a seu lar e, então, o pássaro cativo perguntou-lhe se trazia boas notícias da Índia.

- Receio que minhas notícias sejam más. Um de seus parentes teve um colapso e caiu morto aos meus pés quando anunciei que você estava preso numa gaiola.

Mal essas palavras foram pronunciadas, o pássaro do mercador sofreu um colapso e caiu no fundo da gaiola.

- A notícia sobre a morte de seu parente também lhe trouxe a morte - murmurou o mercador.

Desolado, recolheu o pássaro e o colocou no beiral da janela. Imediatamente o pássaro reviveu e voou para uma árvore próxima.

- Você pode perceber agora - disse o pássaro - que o que você interpretou como uma tragédia, era, na verdade, uma boa notícia para mim. E como a mensagem, ou seja, a indicação de como me comportar para obter minha liberdade, me foi transmitida por meio de você, meu captor.

Dito isso, afastou-se num vôo largo, livre por fim." 227

Seria certamente possível pensar que a mensagem transmitida de pássaro a pássaro é um lapso que irrompe na cadeia lógica da relação entre o mercador e o pássaro rompendo-a. Agora, trata-se de pássaros parentes. Se o que envia a mensagem e o que a recebe são da mesma espécie, podemos, sob um aspecto, considerar que se trata do mesmo pássaro em seus dois "polos": um ego aprisionado e um coração desejante e livre. E ambos se comunicam de um modo que o mercador desconhece.

${ }^{227}$ História extraída do livro Dervish Tales, compilação de Idries Shah, op. cit. 
Se os pais educam seus filhos para realizar um desejo narcísico, a singularidade, de modo paradoxal, está implicada nesse processo. Pois, com toda a evidência, se alguém diz: "quero que meu filho seja engenheiro", esta formulação - que é falada, que é consciente - não é o desejo inconsciente. Esta seria uma forma imaginária do desejo. Se é inconsciente, é porque, nos termos de Freud e Lacan, está recalcado e, como tal, não pode ser dito pelo eu, só pode ser dito pelo sujeito do Inconsciente. No entanto, na perspectiva em que me coloco aqui e para efeito do que estou buscando construir, está recalcado porque não encontrou o pouso simbólico no qual pudesse ser dito, isto é, a forma na qual esse desejo não fosse confinado e confundido com a rigidez de uma forma: engenheiro. A forma "engenheiro" é por demais pequena para conter o tamanho do desejo e suas asas, é uma gaiola fixa no ar, como um vôo cristalizado, anti-vôo, ainda que no ar.

Desse modo, há um transbordamento do desejo tornado angústia num processo que envolve o atormentamento da alma: a alma é ao mesmo tempo o mercador - que aprisiona - e o pássaro - que se quer liberto. Da luta entre ambos, da alma que se nega e se contorce, resulta uma exigência de libertação que incita e excita o desejo, forjando um meio para a vinda da mensagem do pássaro de lá para o pássaro de cá, aproveitando-se da viagem do mercador, oportunista como todo lapso.

Na destruição de um laço, provocada por um simples lapso, há uma analogia com a destruição de uma ordem estabelecida, tomada como punição dos céus num simbolismo rigoroso: o céu é este lugar de medidas angulares (não lineares, como na terra), lugar propício para fazer ver aspectos desse "lado de lá" que é o coração do sujeito.

A mensagem vem, portanto, do "além" para romper o que estava ordenado, vem do oriente, vem dos céus, vem de Deus; a Mística é inequívoca nesse ponto: Deus e o sujeito são "um" no coração. O desejo do homem - este desejo que é distinto do ego - é o desejo de Deus, pois, "Deus está mais perto do fiel que sua própria jugular" (Cor., ), embora, para o ego em seu enclausuramento, a mensagem venha de longe, muito longe, do desconhecido.

"Ó tu, que procuras o caminho que conduz ao segredo, Volta sobre teus passos: pois é em ti que se encontra todo o segredo."228

Mas, o desejo não produz só lapsos ou sintomas. Ele é também construção, criação e luz.

No mundo desencantado, "engenheiro" é uma palavra que remete a uma profissão, entendida sobretudo como um lugar jurídico no espaço público. No mundo encantado, num conto de ensinamento, por exemplo, quando a mulher do sapateiro que virou astrólogo anuncia que seu desejo imperativo é que ele se torne astrólogo, "astrólogo" é muito mais que uma profissão, é a forma simbólica do seu desejo singular.

${ }^{228}$ Ibn 'Arabî, cit e trad. por Chodkiewicz, in Illuminations, p 41. 
Assim, diferentemente de uma forma, a forma simbólica é uma cartola de mágico, ao mesmo tempo em que ela se apresenta com um formato "fixo", dela também surgem, indefinidademente, outros formatos. E, notemos, não são apenas outros significados, são também outros formatos. Ser astrólogo, rei, príncipe, cavaleiro, feiticeira, sábio, cavalo, cachorro, carruagem, gênio, lâmpada, escravo, infiel, qualquer um desses formatos é uma cartola de mágico.

Mas, no mundo encantado, nenhuma dessas cartolas pode ser redutível a, por exemplo, "arquétipos do inconsciente coletivo": não são coletivos, são singulares. Esta é uma questão fundamental aqui. Encontrar estruturas comuns a todos, "universais", está muito longe de ser o simbólico que me interessa ${ }^{229}$.

Não obstante, o fato de ser singular não pode implicar em que a forma simbólica seja "subjetiva". Ao contrário, se o par objetivo-subjetivo ainda pudesse ter alguma utilidade no contexto, ela seria necessariamente objetiva.

Dito de outro modo, o desejo pode tomar uma forma imaginária assim como pode tomar uma forma simbólica ou imaginal. A forma imaginária é aquela que encerra o desejo na fixidez de uma "coisa", a forma simbólica ou imaginal é aquela na qual o desejo está em permanente atualidade, variando conforme as linguagens com as quais se harmoniza. A forma imaginária é fixa, tangível e reconhecida pelos outros. A forma simbólica também é tangível, também se põe aos sentidos, porém, ela é uma abertura para um diálogo com o Outro, por meio do símbolo, os homens podem - ou poderiam - tocar-se no Outro.

Dito ainda de outro modo: diante de uma forma imaginária, cada indivíduo pode produzir a sua interpretação pessoal, egóica, relativa à sua história pessoal e com todos os preconceitos inerentes a esta condição. Perante uma forma simbólica, que o saiba ou não, ele pode estabelecer uma relação que não seja subjetivamente interpretativa, que não dependa de uma posição imaginária, mas que, guardando certa analogia com a idéia de percepção em Merleau-Ponty ou com uma experiência de fruição, seja uma relação com uma presença que se abre e se ultrapassa. Em seguida, ao meditar sobre isso e permitir que as questões sejam atravessadas, o ego será marcado pelas novas sendas e produzirá os novos frutos.

Dito ainda de outro modo, ela não é nem subjetiva nem objetiva, ela é singular e pública. Isso quer dizer que a forma simbólica é, como já vimos, uma e uma para cada um.

Assim, no mundo encantado, o túmulo de um santo que transmitia a sua ruhânyya (numa tradução livre, sua "espiritude" ou sua energia espiritual) era uma forma que era ao mesmo tempo uma e uma para cada um. Cada peregrino que a visitasse, encontrava ali uma

\footnotetext{
${ }^{229}$ Esta não pretende ser uma crítica a Carl Gustav Jung. Não tenho nem o tempo nem o espaço mínimos para fazê-lo adequadamente. O que busco aqui é evitar malentendidos, levando em conta que Jung também foi buscar elementos de reflexão no "mundo encantado", embora, insisto, numa perspectiva totalmente diferente da minha.
} 
transmissão, um sobre-dizer daquela peça inerte, que o comunicava com o seu pássaro e com outros pássaros por meio de uma língua simbólica que atravessa e ultrapassa, por definição, a percepção imaginária dos tempos. E, no mundo encantado, o peregrino, em maior ou menor proporção, sabia disso.

Nesse caso, a transmissão simbólica é uma conversa de transbordamentos, é o diálogo não apenas de um sujeito com o Outro mas, fundamentalmente, de sujeitos, de uma cultura com o Outro. Não há porque circunscrevermos toda esta questão ao indivíduo exclusivamente.

A singularidade é, antes de tudo, problemática: ela é desejo e desejo é busca de ultrapassamento mas ultrapassar é sempre em relação a algo, portanto, é fala de liberdade e fala de prisão, é sonho e denúncia. Não é sublimação das limitações do ego nem das vicissitudes da existência, não é um ideal. Ela é corpo e é travessia, ela é uso da matéria da vida.

A classe social é um discurso. A família é um discurso, assim como a escola. Mas, nenhum desses discursos é simbólico, ao contrário, são condicionantes, são determinações exteriores que moldam e fixam o eu, de modo que, em relação e eles, o eu não pode sequer supor uma autonomia. No entanto, não se trata de dizer que a singularidade está além, intocada por esses discursos e que autonomia quer dizer livrar-se deles e "descobrir a singularidade no fundo de cada um". A singularidade não está "no fundo", ela é um diálogo com o Outro por meio dos outros.

No espaço narcísico, os homens constróem identificações e lutam para que elas tomem forma perante os outros. $\mathrm{O}$ "bem comum" é uma forma racionalizada e útil para um certo tempo e um certo lugar, de modo que ele serve de guia consciente para a construção dessas formas. Por detrás da consciência ${ }^{230}$, isto é, de um modo que não pode ser abarcado pela consciência devido à multiplicidade de linguagens, os homens dialogam com o Outro e, assim, fazem interpretações imaginárias e/ou singulares e recriam, modificam, alteram o bem comum.

Hoje, em algumas "tribos" ou "segmentos da população", o "bem comum" chama-se "sustentabilidade" e nesse "conceito" vemos a macro-articulação entre o interesse individual e o comum. Em última análise, as ações privadas podem ser consideradas sustentáveis se elas não causarem nenhum tipo de dano ambiental, social ou ético. $E$, o que é interessante, a sustentabilidade não é considerada uma utopia. Por "ética", entendem "o respeito ao outro".

No "espaço público" da internet, uma norte-americana, após o conturbado término de seu casamento, colocou no YouTube o relato de sua vida íntima com o ex-marido. Foi um "su-

${ }^{230}$ Aqui não se trata de utilizar o termo "inconsciente" pois o campo teórico é outro. 
cesso" de público, computando acessos da ordem do milhão. No Brasil, uma atriz - que, em outros tempos, trabalhou com a obra de Brecht e teve um denso currículo político atingiu finalmente a fama ao ser vista no YouTube, num filme engraçadinho sobre seu vínculo com a maconha. Outro grande êxito foi a moda seguida por "gente de todo tipo" de filmar suas relações sexuais e postar "o momento do gozo". Poder-se-ia ver aí um paralelo com as primeiras publicações do período moderno ${ }^{231}$ nas quais surgiram as crônicas "pessoais" e a construção das bases que culminaram, por exemplo, num Balzac. No entanto, há que se observar uma diferença: o quanto de inteligência (imaginação, emoção, contato, sensibilidade, etc.) é preciso num caso e no outro?

A sustentabilidade exige um pensamento complexo. Pensá-la de modo consequente implica articular domínios diversos, propor negociações e entendimentos. No entanto, não se trata de qualquer entendimento pois, aqui também, a ideologia faz suas artes. Um número crescente de escolas de Educação Continuada no Primeiro Mundo volta-se para a sustentabilidade e para a "visão de todo". Seus currículos incluem aulas de culinária orgânica, meditação, técnicas "espirituais" do oriente e ciências integradas. Algumas questões, porém, devem ser levantadas. Por que, nesses currículos, a ênfase à História é tão pequena? Por que não se considera necessário o conhecimento das culturas que produziram a Yoga, o Ying e o Yang, a dança derviche, ou qualquer outra "técnica" incluída no currículo, sob o guarda-chuva da tolerância à diversidade? Podemos de maneira tão natural acolher o diverso ou, para fazê-lo com tanta ligeireza não seríamos, na realidade, forçados a uma pasteurização? Não seria a História um importante instrumental contra a pasteurização?

Outro ponto. Uma palavra de ordem comum a essas perspectivas é "ser positivo". Entre outras coisas, ser positivo quer dizer "buscar contribuir em vez de só criticar", "fazer, em vez de ficar só na teoria" e "buscar a negociação em vez do conflito". É perfeitamente possível, para mim, ser uma pessoa "positiva" e compreender as motivações de tal palavra de ordem: todos nós sabemos o quanto os maus hábitos da queixa excessiva, do antagonismo, da teorização abstrata e do apego condicionado a idéias rígidas ou generalizações é pernicioso. Agora, se as motivações são aceitáveis, as implicações, ao contrário, são assustadoras. Vejamos.

Os homens possuem ego. O ego, muitas vezes, possui os homens. Dentre os mecanismos para estabelecer relações possíveis entre a diversidade egóica está a democracia, ou seja, a possibilidade de que os homens comparem seus pontos de diferença. Dentre os instrumentos para esta comparação estão a crítica, a teoria e o acolhimento do conflito. Sem eles, a chance de uma anulação da diversidade é grande. No caso citado, como se trata de um grupo que se acredita democrático, todos acham que a diversidade está contemplada. E ninguém percebe a tirania subjacente: a da eficiência. "Você pode ser diferente, desde que não atrapalhe o andamento positivo das coisas".

Em síntese, há muita religião e pouca política nessas escolas. Agora, a positividade pensa-

\footnotetext{
${ }^{231}$ Ver a respeito, Habermas, Mudança estrutural do espaço público, op. cit.
} 
da como possibilidade de desidentificação egóica é uma outra coisa. Trata-se aqui de algo muito diferente da "eficiência" pois, diz um hadit, "trabalhe como se fosse viver mil anos e reze como se fosse morrer amanhã".

Ensinar o entendimento político é tarefa possível. Ensinar o pensamento analógico e as posições de aprendizado, construir cenários e desconstrui-los, realizar mudanças de posição imaginária e simbólica, descobrir espaços singulares e buscar o conhecimento intuitivo do outro, trazer técnicas de outras culturas e traduzi-las para o nosso momentum, tudo isso, parece-me, são coisas possíveis. 


\title{
2.12 A CIÊNCIA DA CORTESIA ('ADAB)
}

\begin{abstract}
"A primeira coisa que Deus deu a seus servos como uma ordem foi a reunião. Isso não é nada mais do que $a d a b$, uma palavra derivada de ma'duba, banquete, ou o ato de reunir-se para comer em conjunto, exatamente como $a d a b$ é a reunião de tudo o que é bom. O Profeta, sobre ele a graça e a paz, disse: 'Deus instilou adab em mim', isto é, fez de mim o lugar da perfeição." (Ibn 'Arabî)
\end{abstract}

O Mundo Encantado não é o Paraíso terrestre, portanto, não é sempre que é possível "receber intuições", "viver no instante", "encontrar-se com o atual", ver tudo "a partir do coração". Há uma outra estrutura que pode, por assim dizer, funcionar como um suporte racional a ser utilizado na "ausência" da intuição e do atual.

O 'adab, a ciência da cortesia, é uma urdidura racional posta no espaço público como uma espécie de estrutura propiciatória.

Para um muçulmano atual, o 'adab poderia corresponder ao que entendemos por boa educação ou polidez. Trata-se de ser gentil com os outros, acolhedor, hospitaleiro, solícito, cordato, afável e generoso. Trata-se igualmente de evitar os destemperos, a ira, o julgamento, o constrangimento desnecessário do outro.

Tamanha simplicidade de termos de referência seria impensável no mundo desencantado: o fato de que o homem que se comporta com 'adab pode simplesmente fazê-lo por hipocrisia esvazia quaisquer das palavras acima. Uma pergunta frequente é a seguinte: como 
posso ensinar "bons modos" a meu filho e ao mesmo tempo prepará-lo para um mundo "literalmente em guerra", no qual "pessoas abusam o tempo todo dos que são leais, puros, ingênuos e de boa vontade"?

Ou em outra perspectiva: "o 'adab não pode ser confundido com a ideológica 'inteligência emocional', que, em última análise, prega a ordem e a submissão à autoridade, etc."

Em outra ainda: "a incapacidade de constranger o outro - que é fraco, suscetível, ofendese facilmente porque esse é o seu meio de manipular as pessoas - é uma fraqueza disfarçada de cortesia. É um exercício sistemático de hipocrisia e de elogio à sedução barata. É preciso poder criticar e constranger o outro, caso contrário, o 'adab não passa de 'bom comportamento' no pior sentido da expressão".

Atravessando tais questões, o 'adab, no contexto aqui apresentado, é exercício racional de denarcisação. Não se trata de evitar constranger o outro para não ofendê-lo em sua posição imaginária, não se trata de acatar soi-disant autoridades, vaidades, auto-enganos, cristalizações, numa palavra, não se trata de respeitar "o ego".

A polidez aqui é vista, por um lado, como uma espécie de ensaio de amor, de construção de um campo propiciatório. Por outro, como um exercício de negação da própria reatividade.

Reatividade é um termo genérico para designar as formas abstratas de reação a uma situação. A forma abstrata é aquela que despreza uma compreensão mais acurada - intuitiva ou racional - da situação.

\section{A história do macaco}

Um homem dirigia de madrugada por uma estrada. De repente, o pneu de seu carro furou e ele teve que parar no acostamento. Preparando-se para substituir o pneu furado pelo estepe, percebeu que havia esquecido em casa o macaco. Desconsolado, olhou em volta com a esperança de encontrar um meio de pedir ajuda. A estrada estava vazia, tudo escuro e silencioso. Foi então que ele viu, a cerca de uns 200 metros, uma pequena luz que iluminava a entrada de uma casinha. $\mathrm{Na}$ garagem, dava para ver algo que parecia um carro estacionado. Supondo que o dono da casa deveria ter um macaco, pôs-se a caminho para pedir a ferramenta emprestada.

Durante o caminho, no entanto, começou a pensar que o dono da casa estaria dormindo, pois já eram 3 da madrugada. Sentiu-se constrangido com a idéia de acordá-lo, porém, logo ponderou que se tratava de uma emergência, o que o absolvia eventualmente. Mais adiante, no entanto, ocorreu-lhe que ele fora muito distraído por esquecer o macaco em casa e, em seguida, que ele fora, na verdade relapso. Certamente, imaginou, o bom homem que ali dormia, depois de um exaustivo dia de trabalho, não merecia ser acordado no meio da noite por um ir- 
responsável. Esses pensamentos quase fizeram com que ele desse meia volta. A idéia de passar a noite sozinho na estrada esperando um socorro que haveria de tardar muito Ihe parecia bastante mais aversiva que o incomodo de ser inconveniente, portanto, ele seguiu em frente. E sua imaginação seguiu também. Ao aproximar-se cada vez mais da casa, seu constrangimento aumentava. "Mesmo que ele seja um sujeito amigável, em algum momento há de me perguntar a razão pela qual não tenho um macaco e eu terei que confessar-lhe meu esquecimento. Isso provavelmente o deixará bastante desgostoso. Ou talvez irado mesmo, afinal, não é fácil ser acordado no meio da noite e ainda por cima por um estranho relapso. Se ele for um tipo raivoso, então... sabe-se lá o que pode fazer." Seus pensamentos iam soltos a sua frente, como um daqueles cachorros mal treinados que arrastam seus donos pela rua. "No entanto, veja bem caro amigo, não fiz isso de propósito, isso nunca me aconteceu antes, eu não sou distraído, sou até um cara muito sério, organizado, só toquei a campainha por tratar-se de uma emergência. Não, não, o senhor não está me entendendo, eu the peço mil desculpas. Sim, sim, o senhor tem toda razão mas o que é que eu poderia fazer nestas circunstâncias? O que o senhor faria? Bem, o senhor poderia ser mais compreensivo, ter um pouco de solidariedade, eu não sou nenhum criminoso, pago meus impostos. Mas, afinal, que país é esse? De que adianta sermos cidadãos honestos se não podemos contar uns com os outros? O senhor não está sendo minimamente razoável, isto, na verdade, não é nem mais egoísmo, o que o senhor está fazendo é uma desumanidade".

Totalmente imerso em seus pensamentos e bastante agitado, ele tocou a campainha quase sem se dar conta. Quando um homem sonolento abriu a porta, ele lhe gritou louco da vida:

- Pois muito bem, quer saber de uma coisa? enfia esse seu macaco no c....!"

Podemos, evidentemente, investigar as causas ou os processos pelos quais cada um de nós se vê, frequentemente, tomado por fantasias e agindo com base nelas exclusivamente. No entanto, o que a perspectiva do 'adab considera é simplesmente o fato de que as fantasias que geram a reatividade podem ser evitadas. $O$ enfoque aqui é pedagógico, não terapêutico. Há, portanto, um trabalho técnico a ser feito sobre a imaginação.

Em primeiro lugar, não é tarefa simples perceber a fantasia. O caso da história acima pode parecer um exagero, no entanto, se uma pessoa se encontra muito identificada com a sua posição, essa situação é perfeitamente comum. De um modo geral, a pobreza imaginária do espaço público torna tais situações aberrantemente comuns.

Um professor, ao ver um aluno olhando no relógio, supõe que ele esteja ansioso para que a aula termine. Um homem, ao ver sua mulher olhando outro homem numa mesa de restaurante, supõe que ela esteja se sentindo atraída sexualmente. Um policial no metrô de Londres supõe que um homem de capa preta seja um terrorista. O problema é que essas suposições ensejam reações efetivas como se a suposição fosse automaticamente verdadeira em vez de ensejar uma ponderação: 
- "não posso ter certeza quanto aos sentimentos do meu aluno, porém, qual o problema de ele estar ansioso para que a aula termine? isso, em princípio, é da conta dele, ou, por outro lado, talvez eu possa conversar com ele a respeito, talvez, inclusive, eu descubra que minha aula pode tornar-se melhor".

- qual o problema se a minha mulher se sente atraída por outro homem? etc.

- um homem, seja terrorista ou não, possui direitos e não pode ser morto só porque eu estou sendo pressionado como policial, etc.

O leitor pode supor aqui que eu esteja simplificando em demasia a questão, no entanto, o propósito aqui é fazer ver um aspecto que acaba sendo pouco abordado justamente por tangenciar as abordagens comportamentais reducionistas. No entanto, é preciso atravessar essas questões se se trata de pensar múltiplas consequências da denarcisação. Aqui, se trata de ver que disciplinar a imaginação não quer dizer "domá-la" mas, sim enriquecêla. Não se trata de dizer "não imagine" e, sim, "imagine mais e melhor". O problema é que esse "melhor" deve passar por um trabalho de crítica ideológica que passa a ser fundamental na Educação. Nesse sentido, é evidente que ler Shakespeare - cuja obra é um tratado de psicologia encantada ${ }^{232}$ - é melhor que ver um filme americano, embora essa afirmação, fora do contexto, seja reducionismo.

Dito de outro modo, o 'adab corresponde a uma inteligência imaginativa que precisa ser desenvolvida com o objetivo de favorecer o encontro e a descoberta de posições imaginárias de melhor qualidade.

A ética e a estética formam um par encantado no 'adab: as artes cumprem o papel de ensinar os sentidos a se relacionar com as coisas como se fossem linguagens e a ética os orienta para a denarcisação, portanto, para abrir a todo momento os espaços para o Outro, a dimensão fundamentalmente pública do Encantamento.

Dito ainda de outro modo, a cortesia é a linguagem por meio da qual ensinamos às nossas crianças como o lugar do "dever" prima sobre o lugar do "direito". Se pensarmos, no entanto, que o dever é moral e ideológico, estamos aderindo a uma campanha do partido republicano americano. Se pensarmos, ao contrário, que o dever consiste na denarcisação como atitude política, estamos numa perspectiva na qual a responsabilidade de cada um é integral. Qualquer outro é público e qualquer outro é político e, neste espaço, o dever está posto, não sendo dever para com o outro e sim para com o Outro.

A cortesia exerce uma pressão forte sobre a reatividade. Desse ponto de vista, o 'adab seria a linguagem da cortesia, isto é, poder reagir a cada situação com harmonia, garantindo as possibilidades de fluidez, de improviso, de criatividade, de acolhimento do conflito, de crítica, de erro, de construção, etc. Com o seguinte acréscimo: quando não é possível ter o talento do 'adab, isto é, ter desenvolvido a capacidade de se relacionar com o 'adab como uma linguagem, ele pode ser um comportamento forjado. Em outras palavras, salvo exceções, a gentileza, mesmo falsa, condicionada, reativa, posa como melhor que a descorte-

\footnotetext{
${ }^{232}$ Ver a respeito Martin Lings, "Shakespeare in the light of sacred art", op. cit.
} 
sia do ego embrutecido. As exceções a que me refiro são aquelas em que alguém, com toda a evidência, merece levar um tapa na orelha, mas, nesse caso, qualquer pessoa pode, em tese, saber em seu íntimo se o que a levou a dar o tapa foi uma oportunidade concreta ou uma reatividade banal.

O pressuposto encantado da cortesia reside, inicialmente, na constatação banal de que a situação em que um homem se permite um ato descortês, usando qualquer forma de hostilidade, desde uma simples ironia até qualquer gesto agressivo ou irado, consiste, a longo prazo, numa atitude extremamente perigosa para ele mesmo. No entanto, atravessar esta matéria é como passar por uma ponte de fina corda sobre o precipício do pior dos moralismos. Todo cuidado é pouco.

A constatação a que me refiro é a de que, ao habituar-se a reagir com justa indignação frente a uma comprovada vileza, alguns poderão tender a reagir com a mesma indignação frente a vilezas não tão comprovadas. Ao sacar vitoriosamente sua espada para defender fracos e oprimidos, alguns poderão não resistir mais à tentação de sacar sua espada para exibir sua força para outros. Ao ter razão numa querela, alguns podem fechar-se a ponto de sentir ódio por aquele que não se curva ao argumento impecável. Numa palavra, o perigo reside na identificação narcísica.

Note o leitor que haverá divergência entre uma visão propriamente psicanalítica e esta aqui apresentada. Nos termos do 'adab, mesmo podendo ser considerada um "mecanismo de defesa do ego", uma tal identificação não seria "estrutural". Ela seria vista muito mais como um mau hábito, uma autoindulgência, uma indisciplina que uma formação inconsciente. Meu propósito não é negar a formação inconsciente, é olhar para a questão com uma outra lente, focalizando, portanto, uma outra questão.

O filho de oito anos de uma amiga disse à mãe que não gostava de ter razão. Quando ela Ihe perguntou o porquê disso, respondeu-lhe que "quando a gente tem razão, a gente fica com o coração de pedra". Nunca soube de onde o menino genial tirou essa conclusão. Apenas guardei seu ensinamento.

Conta-se que um rabino de 101 anos recebeu, certo dia, um curioso que queria conhecer a fórmula de sua longevidade.

- É muito simples - respondeu-lhe o sábio - eu nunca discordei de ninguém.

- Nunca? - gritou o homem - Mas isso é impossível!

- O senhor tem toda razão.

Dito de um outro modo, a reatividade não pode ser confundida com a aceitação do conflito. O conflito é uma realidade na qual há contradições a serem aceitas e atravessadas. A reatividade é apenas um antagonismo.

O 'adab não é em si uma denarcisação no sentido mais completo do termo, ele é uma restrição denarcisadora. 
Desse modo, o trabalho de tradução do 'adab para uma pedagogia contemporânea permite recolocar, sem as indevidas abstrações, o critério fundamental de que agir por meio da força é privar-se de agir por meio da inteligência.

De modo técnico, essa estrutura é parte da imaginação, ela consiste de ensaios e encenações, de "mentira por verdade" como disse o narrador da Terceira Margem.

Não se pode subestimar, em qualquer perspectiva, o caráter de cristalização do aparelho psíquico. Olhando para o ego como aparelho, não importam as distinções de classe, de época, etc. O que constatamos é que há um processo de enrijecimento gradativo: das posições imaginárias assumidas ao longo da vida, dos gestos e dos processos corporais, dos hábitos e condicionamentos, da "consciência de si e do outro". É essa cristalização que Ibn 'Arabî, como vimos, chama de ardil divino.

Poderíamos também usar o termo "condicionamento", explicitando agora um dos modos com que o utilizamos acima: o ego constrói posições imaginárias, mundos imaginários, histórias imaginárias; em cada posição, em cada mundo, em cada história, há um conjunto de reações e ações previstas, papéis determinados, idéias preconcebidas, tudo está condicionado a estas posições, ou a estes mundos ou a estas histórias, etc. Em alguns momentos, rompemos com esses condicionamentos. Às vezes, são pequenas rupturas, frestas, produzidas por uma fruição estética, uma intuição fugaz, um ato falho. Às vezes são angústia, o Real sem um lugar singular onde por-se. Às vezes são uma ruptura efetiva no condicionamento na qual o mundo imaginário se desfaz. Em todos esses casos, o ego "morre" de algum modo e, em todos eles, outros mundos imaginários são refeitos e o ego "renasce". Mais raramente, há uma ruptura efetiva que põe o homem diante de "um" simbólico. Nesse caso, ele encontra uma cartola de mágico e daí irá "tirar" inúmeras ciências.

Como vimos, o surgimento do indivíduo, no âmbito da República moderna, corresponde a uma grande inovação. Os homens passam a conhecer um certo tipo de liberdade e um certo tipo de experiências inauditos em regimes anteriores, abre-se um novo portal, surge um novo mundo. No século $X X$, a identidade constitui-se finalmente como forma do indivíduo e como objeto de estudo das ciências humanas. Hoje, como diz Bauman, "as identidades ao estilo antigo, rígidas e inegociáveis, simplesmente não funcionam".

Os alunos não obedecem aos seus professores. Não somente porque não têm medo - o fundamento do vigiar e punir. Eles também não têm pouso. Penso na desnutrição simbólica do nosso tempo: os pais não sabem mais fundar uma construção identitária em seus filhos, a sociedade tampouco. Desde a "formação" proporcionada pela mídia, pelos videogames, pelo google e a inflação dos antagonismos - nos formatos mais variados, no discurso político, na novela, nas escolas, nas conversas -, até o tipo de alimentação e os hábitos corporais, produzem ao mesmo tempo uma "astenização", um excesso de excitação e um enrijecimento, uma espécie de laxismo rígido ou de preguiça fundante. Os alunos não podem concentrar-se, acalmar-se, pacificar-se porque a incrível excitação os 
atinge em cheio e, ao mesmo tempo, não são verdadeiramente ativos. Por açúcar e por afeto, as crianças fazem e são qualquer coisa. Os pais e os professores são reféns dessa barganha em que todos perdem.

Esta sociedade sem lei é, não por acaso, o ninho dos julgamentos. Todos julgam. O telespectador julga o artista porque sua "vida privada" aparece nas revistas, julga o político porque suas "ações" são denunciadas na TV. O pai julga o professor, o professor julga o pai. O amigo julga o amigo, o colega julga o colega. O país julga outro país. Trata-se de um julgamento imaginário, evidentemente: são formulações imprecisas, via de regra confundindo crítica com xingamento e abstendo-se das fases da investigação, do inquérito e, sobretudo, da defesa, que deveriam fazer parte de qualquer julgamento. Passam "pragmaticamente" da acusação categórica à conclusão condenatória. Isso é possível pela intensa imaginarização proporcionada pela falta de lei. Se não há lei, não há critério. Se não há critério, o julgamento é simplesmente o hábito mental que constrói as "justificativas" do antagonismo. O Iraque foi invadido e destruído por ter construído armas nucleares. Sem provas, sem defesa. Um professor, na Universidade, difama pelos corredores outro professor. Sem provas, sem defesa. E muitos se espantam quando um adolescente entra armado numa escola e mata seus colegas e professores. A "construção identitária" permite isso, sendo baseada na imitação puramente mental e fictícia (não baseada no "acoplamento" e na Lei simbólica) de um "modelo" midiático (que não é modelo no sentido com que o termo está sendo utilizado aqui, pois é um padrão a ser reproduzido, uma cópia), "produtor de identidades", no caso, a grife "neonazistas". O julgamento é uma interpretação violenta do outro.

O 'adab, ao contrário, é uma autoproibição de julgamento: a idéia de que todos são inocentes até prova em contrário não é uma fórmula-clichê repetida por aqueles que não praticam o que professam. Para evitar os julgamentos, é necessário desenvolver a faculdade imaginativa. Nas relações de cortesia, há uma arte refinada que é a de imaginar razões para que "o outro" aja como agiu. A atitude consiste em ser capaz de reiteradamente ser "o advogado de defesa do outro".

Vimos, no cap. 2.4, que um trabalho de denarcisação consiste em ver o outro como um "modelo excelente". Vimos também que podemos ver o outro como linguagem (cap. 2.10) ou, no próximo capítulo, como urdidura. O 'adab é um procedimento racional de tentativa de atuar como se fôssemos capazes de realizar integralmente tudo isso.

Portanto, não se trata de ensinar nossas crianças a serem "boazinhas" ou "bem comportadas". Trata-se, por um lado, de ensiná-las a denarcisação e o desapego, e, por outro, a ver o outro criativa e construtivamente. Nesse contexto, a positividade cumpre um papel técnico. Ela consiste num trabalho de buscar a conversão de uma situação desarmônica numa situação harmônica. 


\subsubsection{AS ATRIBUIÇÕES DE SIGNIFICADO}

Quando me referi acima à possibilidade de reagir a cada situação com harmonia, quero agora precisar melhor essa idéia.

A reatividade é um termo apenas descritivo e bastante genérico, ele designa vários modos de reagir abstratamente: fazendo pressuposições acerca das intenções dos outros, fazendo o que a PNL chama de "leitura mental" (achar que sabe o que se passa no íntimo de uma pessoa apenas olhando sua expressão facial), ou tirando conclusões apressadas, ou colocando palavras na boca das pessoas, ou deslocando o foco da idéia para a pessoa, como, por exemplo, se alguém afirma que prefere pensar melhor antes de tomar uma certa atitude e o outro responde que ele é um covarde ou um fraco, etc.

Além do, digamos, mau hábito narcísico, que o 'adab teria por função enfraquecer, há também o mau hábito da significação imposta ao outro, que o 'adab deve restringir.

Imaginemos alguém que se encontra trabalhando junto a uma equipe durante um certo período de tempo. Algumas semanas após o término do trabalho, esta pessoa cruza com um dos membros da equipe num corredor e mal a cumprimenta. A pessoa que é "mal cumprimentada" pode atribuir um significado ao gesto:

1. "nem me deu bola... provavelmente nem se lembra de mim... minha atuação na equipe não foi significativa..."

2. "ela se acha muito importante, não vai interromper seu passo para me cumprimentar, não fala com qualquer um"

3. "ela é muito competitiva, não pode deixar que os outros pensem que ela me considera pois teme que eu tome o seu lugar, já que sou muito melhor."

4. "ela estava com pressa, deve estar com algum problema"

5. "fingiu que não me reconheceu, está se fazendo de difícil"

E assim vai. Atribuímos significados aos gestos e às palavras dos outros. As consequências e as implicações disto são inúmeras. Dentre estas, a recusa em perceber que se trata de uma atribuição de significado e não de uma "percepção" é uma das mais graves. Na prática, cada vez mais, os homens interpretam-se erraticamente, sob orientações puramente imaginárias e, com frequência, situando-se nas esferas mais vis do comportamento humano.

Como vimos, o homem é o intérprete por excelência dos sinais do mundo e dos outros, é o doador de significação. É nesta condição, paradoxalmente, que se encontra sua maior oportunidade e o maior risco de que essa oportunidade se torne, por assim dizer, perversa.

Se significar é realizar, é abrir-se ao possível e trabalhar a matéria do real para que ela responda significativamente, o efeito perverso desse lugar é, por um lado, a interpretação 
puramente abstrata, denegadora do mistério do outro e, por outro, negar ao outro a mesma condição de intérprete, portanto, de interlocutor misterioso.

Há uma violência sem par na imposição sobre o outro de um certo processo de significação. Dizer "eu percebo", "eu sei", "estou vendo" é uma desqualificação do lugar de intérprete. A interpretação do $\underline{\underline{H}}$ alifat Allah (Califa de Allah) é fruto de intuição e de acoplamento. Quando isso não é possível, o adab é um recurso de evitação da violência da intepretação puramente egóica e sem autocrítica.

Um dos objetivos do modelo pedagógico, que pretendo esboçar na Parte 3 desta tese, é construir um instrumental de crítica (autocrítica) perene da interpretação violenta. Uma crítica não apenas teórica mas, também, pedagógica, como veremos.

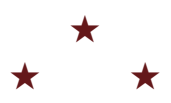

Mexo levemente no caleidoscópio agora, a fim de olhar a questão de um outro jeito. A extrema imaginarização é, como todo mundo sabe, também um fundamento da prática compulsória do semblant. O "bom profissional" sabe fazer a pose de que é bom profissional. Não adianta ser bom, é preciso saber mostrar, e se você sabe mostrar, obviamente, você não precisa ser bom. Todo mundo sabe disso. O grande "aprendizado", o mais decisivo, consiste em aprender a fingir bem. Há uma série de códigos, que não podem ser infringidos, que vão do vestuário à entonação da fala. Ninguém tem a menor certeza quanto às suas reais capacidades. Portanto, todos são fundamentalmente frágeis e sem lastro, portanto, investem toda a sua energia na construção da correta aparência, da "imagem da marca", e vivem sob extrema tensão. Sob certos aspectos, a construção das identidades é substituída pela construção dos semblants, com as vantagens análogas às das casas préfabricadas ou de qualquer produto descartável.

Agora, uma questão que mereceria reflexão, no caso, seria a da capacidade simbólica da "identidade semblant", isto é, a capacidade de suportar, de abarcar, de impregnar-se e de fazer brotar.

A princípio, esse tipo de identidade não teria nenhuma capacidade simbólica pois o trabalho de parecer algo - de parecer-se com Angelina Jolie ou com Madonna ou com Roberto Carlos, de "estar sentindo" algo, de saber qual a reação padrão para situações padrão - exclui o trabalho de construção, de arar a terra para o plantio. No entanto, podese supor que haja uma operação possível. No campo da dualidade, é possível passar do grosseiro antagonismo como método reativo a um "patamar" com mais recursos e sutilezas. Assim, é neste ambiente tensamente fluido e engessadamente esfacelado que parece possível conceber homens que possam aprender a mudar de posição imaginária. Sem a rigidez das identidades, as crianças podem aprender a construir internamente as vias de movimentação, de busca, de invenção de lugares. 
O hábito julgador de uma certa vulgarização da psicanálise consiste em afirmar que "os homens são egoístas", que "o narcisismo faz com que as pessoas ajam por interesse", que a generosidade, o altruísmo, etc. "são baseados num interesse pessoal mascarado". Sem me ater em criticar a falta de rigor de tais afirmações, quero chamar a atenção para o fato de que a experiência de generosidade não é antagônica à do "interesse pessoal". Ela é um outro cenário. E se, em vez de ensinarmos nossas crianças a construir semblants, pudéssemos ensiná-las a construir cenários de veracidade interna? Há uma posição imaginária em que, por exemplo, uma criança age de modo interesseiro. Isso custa energia, empenho, concentração. Há um cenário interno de sustentação do semblant. No entanto, uma criança pode aprender a fazer a mesma ação a partir de outro cenário. De um cenário de generosidade (ainda não vou discutir o problema das virtudes), por exemplo. Aprender a construir cenários internos é diferente de construir identidades. Mas é uma prática que partilha da mesma solidez da identidade, sendo, ao mesmo tempo, muito flexível.

Penso que não se pode deixar o mercado, a mídia, as pessoas à deriva, que é preciso lei e é preciso "lugar de pouso" do simbólico. No entanto, a idéia de Revelação, como tal, não pode vigorar no mundo desencantado. Qual seria sua "tradução" hoje, isto é, como resgatar a relação entre o fixo e o mutável da lei simbólica?

Em outras palavras, se um excesso de imaginarização sem lei conduz a uma falsa plasticidade, é justamente um uso "ético" da imaginação - do como se - que pode conduzir a um re-encantamento em outras bases.

Dito ainda de outro modo, no âmbito ético-político, o "desapego" não é uma forma de "frustração individual em benefício da necessidade comum", como se define a república, tampouco de princípio da realidade versus princípio do prazer, conforme a equação "republicana" de Freud. O desapego, como estrutura operativa, é a possibilidade da construção de um espaço público simbólico. 


\title{
2.13 O ESPAÇO PÚBLICO SIMBÓLICO
}

\begin{abstract}
"Abu Yazid al-Bistami destacou os diferentes níveis de percepção quando disse que, na primeira vez em que visitou a Kaaba, na Meca, viu a Kaaba. Na segunda, viu o Senhor da Kaaba. Na terceira, não viu nada disso, nem a Kaaba, nem o Senhor da Kaaba." ${ }^{233}$
\end{abstract}

O horóscopo de um evento corresponde, como no desenho abaixo, à projeção, sobre algum lugar da terra, da posição dos planetas tal como se encontram no céu ${ }^{234}$ em um determinado momento.

A linha definida por uma flecha à esquerda marca o Ascendente, ou seja, o grau do signo que está ascendendo no horizonte na hora exata do evento. Este lugar se mostra à experi-

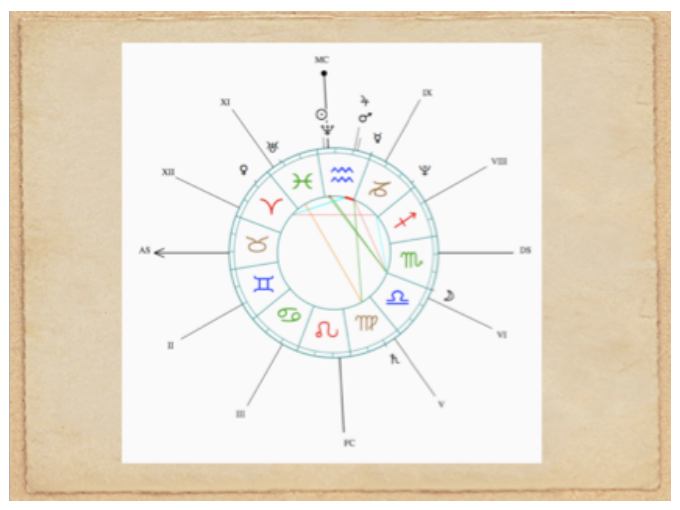

fig 1

ência sensível quando dirigimos nosso olhar para a linha do horizonte, à leste. Ali, correspondendo à altura do olho, "vemos" esse ponto. Como "leitura" dessa experiência, pode-

\footnotetext{
${ }^{233}$ Idries Shah, "Aprender a aprender", op. cit., p. 62.

${ }^{234}$ Falando de uma forma mais precisa, trata-se da projeção na terra da posição dos planetas em relação ao Zodíaco, que é uma construção imaginária em torno da eclítica, a órbita aparente do sol ao redor da terra.
} 
mos dizer que o ascendente é o que está à altura dos olhos, isto é, o que se vê. Se o evento em questão é o nascimento de alguém, dizemos que o ascendente marca aquilo que dela vemos à altura dos olhos, sua marca primeira: o rosto. Portanto, se o ascendente é áries, ela tem, segundo se diz na ciência astrológica, "cara de carneiro", se é libra, tem "cara de gazela"; sagitário, "de cavalo" e peixes, "de elefante", conforme definido pela simbólica zodiacal ${ }^{235}$.

O simbolismo também indica que, se se trata de uma projeção celeste na terra, o resultado dessa projeção, isto é, a sua "sombra" terrestre, determina as áreas de experiência "aqui e agora" dos possíveis, "colocados" naquele momento celeste. Essas áreas de experiência são chamadas de "casas" e aparecem no desenho, em sentido anti-horário, como esses espaços numerados por algarismos romanos, alguns dos quais "contendo" planetas: o sol $(\odot)$, a lua ( () , vênus $(\$)$, etc. Assim, a casa 1 coincide com o ascendente e, pela mesma via, corresponde às áreas de experiência nas quais um evento ou uma pessoa se dão aos olhos, são vistas.

Uma das confusões habituais da astrologia moderna ${ }^{236}$, concebida pós Desencantamento do mundo, é dizer que a casa 1 corresponde à identidade de uma pessoa. No entanto, se pensarmos agora a identidade como uma urdidura, não como uma trama fixada, podemos concebê-la como uma estrutura vazia sobre a qual quaisquer tramas podem tecer-se: o Dom Quixote que sabe quem é e, por isso, pode ser quem queira. A casa 1 é então o lugar simbólico e imaginário ${ }^{237}$ no qual construímos, incessantemente, nosso lugar de sermos olhados e/ou vistos, nosso lugar de semblant, nossa(s) imagem(ns) e auto-imagem(ns), nosso palco, nossa janela, nosso lugar de apresentação.

Se a casa 1 pode ser dita, a partir do caminho feito acima, a "casa do eu", a casa 7, oposta à 1 e, portanto, seu par complementar é, numa dualidade operativa, a "casa do outro".

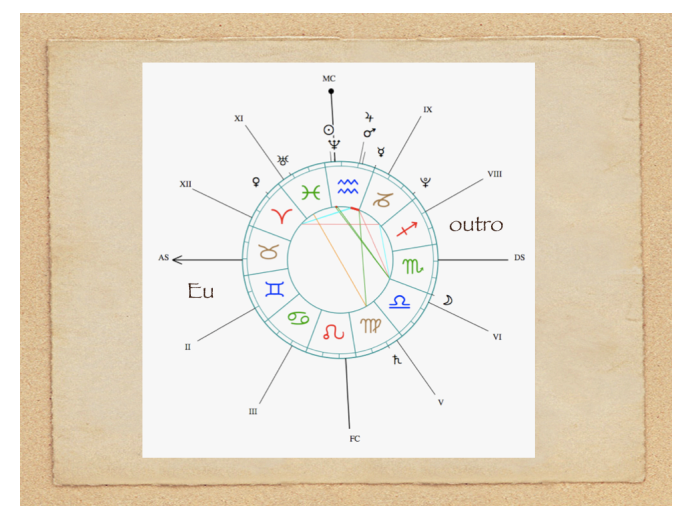

fig 2

\footnotetext{
${ }^{235}$ Aries - carneiro, touro - boi, gêmeos - passarinho, câncer - sapo, leão - leão, virgem - cachorro, libra gazela, escorpião - serpente, sagitário - cavalo, capricórnio - cabra, aquário - homem e peixes - elefante.

${ }^{236}$ Cf essa questão, em maior detalhe, no capítulo "Por uma epistemologia da ciência tradicional", in Sentidos..., op. cit., p. 245.

${ }^{237}$ A experiência imaginária, como vimos brevemente, fixa uma trama, uma identidade única e inflexível; a simbólica abre a urdidura a outras tramas.
} 
Se o leitor se lembrar das passagens em que trato das dualidades operativas, poderá facilmente observar que esta distinção entre o "eu" e o "outro" não é fixa e encontra-se em permanente movimento.

O eixo casa 1-7 pode ser chamado então de o lugar do "entre olhares".

Mexendo levemente, agora, no caleidoscópio, veremos um novo arranjo: (ver fig.3) o mesmo desenho comporta também o movimento aparente do sol em torno da terra. Assim, em sentido horário, temos que o sol na aurora (+ou- às 6hs. da manhã) à esquerda do desenho, chega ao seu ápice no alto da figura, por volta do meio-dia, e se põe no crepúsculo (+ou- às 6hs. da tarde), à direita. Desse modo, o crepúsculo está no mesmo lugar da casa 7.

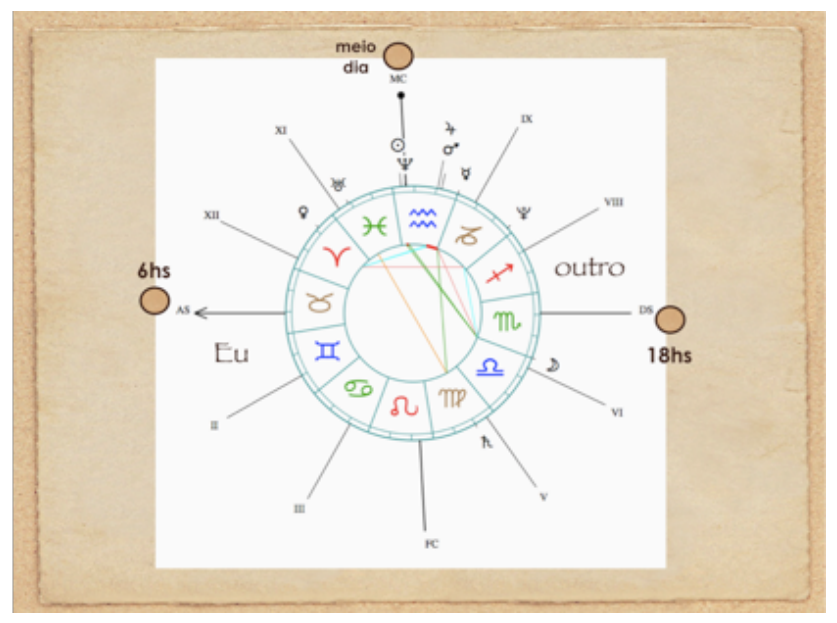

fig 3

No cair da tarde, a primeira "estrela" que aparece no céu e marca o crepúsculo é a "Estrela Vésper", onde, como todos sabem, está a Terra do Nunca. Essa estrela, nem todos sabem, é o planeta Vênus ${ }^{238}$.

O momento do crepúsculo é aquele exato "entre", posto ao fim do dia e no início da noite, em que as formas não estão nem distintas nem indistintas, em que não se sabe ao certo se já é hora de acender os faróis do carro ou ainda não. Algumas tradições o chamam de "a hora do tigre", um animal que nos põe em dúvida: é laranja de listas negras ou negro de listas laranja? É a hora do lusco-fusco. Os contornos perdem suas certezas e, por um instante, há um pode ser sugerido no ar. Os sufis o chamam metaforicamente de barzah.

O termo corânico barzah $\underline{\underline{h}}$ que literalmente quer dizer istmo - o que une e separa duas porções -, é utilizado para evocar essa plasticidade, essa realidade intermediária que é o alâm al-hayâl, o mundo da imaginação, ou, para retomar o termo que venho utilizando, o simbólico. Podemos dizer que ele possui algumas das características do indecidível de Der-

${ }^{238}$ Conforme a época do ano, a Vênus aparece na aurora, na altura da casa 2 e, nesse caso, chama-se "Estrela d'Alva". 
rida, embora sua aplicação seja mais ampla.

Lembremos o que foi dito acima sobre o alâm al-hayâal. Em primeiro lugar, a "coisa imaginal", isto é, o símbolo, é o mesmo que cada um dos dois lados que o definem e é distinto de ambos. Em segundo, o mundo imaginal, o simbólico, é uma "vasta terra", e "não fosse essa terra, os corpos e os espíritos jamais se encontrariam".

Barzah entre os corpos e os espíritos, a imaginação é um veículo para a intuição:

"... em Ibn 'Arabî, o conhecimento iluminante mais perfeito se produz na esfera dos inteligíveis, dos puros espíritos isentos de matéria e de forma. É somente em seguida que ele "toma corpo" no âlam al-hayâhl, que ele habita imagens e palavras que possibilitarão transmiti-lo àqueles que não têm acesso a este universo de pura luz." 239

"(...) Allâh, de fato, quando quer me comunicar uma ordem ou uma interdição, anunciar-me uma boa nova ou me por em guarda, ensinar-me uma ciência ou responder a uma questão que eu Lhe tenha colocado, tem por costume arrancarme de mim mesmo - sem que minha forma exterior seja por isso afetada - e depois projetar sobre mim o que Ele deseja por meio de uma alusão sutil contida num verso do Corão. Em seguida, Ele me restitui a mim mesmo, munido deste verso, consolado e satisfeito. Ele me envia a seguir uma inspiração sobre o que Ele quis me dizer pelo verso em questão. A comunicação deste verso opera-se sem som nem letra e não pode ser atribuída a nenhuma direção do espaço. ${ }^{240}$

Desse modo, o simbólico - no caso, o Corão - é este lugar de pouso do singular: o que Ele quer dizer, no momento atual, com um verso específico.

Voltemos ao crepúsculo. Esse momento dura apenas um instante e, no entanto, nós o conhecemos profundamente. O simbolismo astrológico faz coincidir a "casa do outro" (a casa 7) com a "casa da imaginação" (o crepúsculo). Portanto, a imaginação, nesse contexto, é a faculdade por excelência do conhecimento do outro e falar disso requer uma longa travessia.

O outro é um barzah: alguém com quem convivemos, por exemplo, é alguém que reconhecemos facilmente, cuja história em grande parte conhecemos e que, em sua forma corporal, é visível e uno. Ao mesmo tempo, na experiência mais comum e corrente, é um desconhecido. Seu "mundo interior" é misterioso e múltiplo, suas sensações, sentimentos, pensamentos, etc. nos escapam a todo instante. A todo instante, nada sabemos de fato sobre ele. Ele é visível/invisível, conhecido/desconhecido, presente/ausente, coração/ego, feito e por fazer.

\footnotetext{
${ }^{239}$ Chodkiewicz, Océan, p. 110-11.

240 Écrits, p. 157.
} 
Como qualquer realidade, o ser humano é invisível a olho nu. As lentes de que necessitamos para vê-lo são múltiplas e deveriam ser intercambiáveis, essa é a função primeira da imaginação: imaginar o Outro.

"A perfeição (al-ihhsân) consiste em adorar Allâh como se tu O visses, pois, se tu não O vês, Ele te vê. ${ }^{241 " 242}$

Esse lugar entre olhares, essa zona em que "não vês quem te vê, mas o imaginas" é precisamente o lugar da relação com o coração do outro. "Quem ama, diz Ibn 'Arabî, ama o Senhor do outro" 243 .

Obviamente, cada um de nós posto diante do outro irá imaginá-lo - acreditando que o vê - com a imaginação egóica e não com a imaginação simbólica. Há evidente analogia entre ambas as imaginações. A diferença é que a imaginação egóica, deixada a si própria, sem nenhum trabalho de denarcisação, não se deixa fundar pelo "Ele te vê". Dito de outro modo, a imaginação egóica é "cheia", ela é, para usar um termo da época de Ibn 'Arabî, "idólatra", ela se apega a uma forma fixa e não abre espaço para outras formas. Se, inversamente, há desapego - no sentido técnico do termo, isto é, se há descolamento, denarcisação, desidentificação - então essa imaginação - esse lugar de produção - pode ser inundada por Ele, pelo que Ele vê, ou seja, pela Toda-Possibilidade de formas do Outro. Nesse caso, o Outro nos inaugura em sua Visão e é desse lugar inaudito que $O$ vemos/imaginamos, inaugurando-O renovadamente. O outro, qualquer outro, é então um lugar imaginativo, o lugar por meio do qual vemos/imaginamos o Outro desse outro, porque, como já vimos, o Outro é um e um para cada um. E isso, no sufismo, corresponde a uma "definição" de amor.

Louvado seja Deus que fez do amor (al-hawâ') um santuário para o qual peregrinam os corações dos homens cuja educação interior é perfeita e uma ka'aba em torno da qual giram os segredos íntimos dos homens de refinamento espiritual. $^{244}$

\footnotetext{
${ }^{241}$ Alguns poderão dizer que o "Ele te vê" corresponde à fé. Novamente, poderíamos pensar a fé como imaginária ou simbólica. A fé imaginária ou egóica, antes de tudo narcísica, consiste, sob muitos aspectos, em deixar-se capturar pelo "ardil divino". A fé simbólica é um lugar a ser conquistado por meio de trabalho técnico. Parte deste trabalho consiste na conquista da submissão. "Os Beduínos disseram: 'Nós temos a fé'. Diga: 'Vocês ainda não têm a fé, é melhor que digam: nós simplesmente nos submetemos, pois a fé ainda não penetrou em seus corações." (Corão, 49:14). Infelizmente, a questão foge do escopo do presente trabaIho.

242 Buhârî, tafsîr, s. 31; Îmân, 37, cit e trad. por Chodkiewicz, in Océan, p. 194, n. 10.

243 o Senhor (al-rabb) é um Nome de Deus. Ele aparece no par "Senhor/servo" que estabelece uma relação dual entre Deus e o homem e, por analogia, entre o coração e o ego. Ver mais a respeito em Chodkiewicz, Le Sceau, op. cit.

${ }^{244}$ Addas, Claude, Expérience et doctrine de l'amour, op. cit. "Louange à Dieu qui a fait de l'amour (al-hawâ') un sanctuaire vers lequel marchent les coeurs des hommes dont l'éducation spirituelle est parfaite et une ka'ba autour de laquelle tournoient les secrets des poitrines des hommes de raffinement spirituel."
} 
A ideologia moderna põe para o senso comum a crença de que o "conhecimento" é antagônico ao "amor". Este sendo subjetivo, pessoal, incomunicável, imprevisível e indomável, aquele sendo objetivo, comum e científico, isto é, comunicável, previsível e, uma vez dominado, serve de ferramenta para a dominação do homem "sobre a natureza". Pertencendo ao "reino do sentimento" - antagônico ao "reino do pensamento", representado pelo conhecimento - o amor não necessita ser definido e jamais pode ser objeto de conhecimento (mas, segundo essa "lógica", pode ser objeto da filosofia, que não é propriamente conhecimento, "porque não é certeza"), desse modo, quando a Psicanálise Ihe propõe uma estrutura, isso parece simplesmente incompreensível. E o fato de que a "ferramenta" do conhecimento pretende, antes da dominação da natureza, a dominação dos homens, quando notado (o que ocorre, por certo, raramente), é designado como saber "do mal", como um "desvio".

Assim sendo, o amor seria "feminino" e o conhecimento "masculino". Eis porque os manuais de autoajuda, os livros de consultores empresariais, as pedagogias de algumas ONGs "voltadas para a inclusão" e as filosofias "sintonizadas com o novo século" são unânimes em pregar a busca de um "equilíbrio" na vida entre o amor e o conhecimento, o equilíbrio saudável entre os opostos, afinal, in medio virtus est. É por este motivo que "é tão importante para a humanidade", segundo alguns "analistas", que haja mais mulheres em "cargos de poder": porque assim as relações entre os homens tornar-se-ão "um pouco mais amorosas e haverá menos guerras". A imaginação aqui, com toda a evidência, está rigorosamente descartada.

Em outros tempos e lugares, e de modo inteiramente explícito no Mundo Encantado, o antagonismo entre conhecimento e amor não faz sentido: eles coincidem integralmente, são a mesma urdidura sob tramas diferentes. O amor, obviamente, no caso, não sendo um sentimento e, sim, uma realidade imaginativa.

Como tramas diferentes, seria possível distinguir amor e conhecimento sob vários aspectos e, de fato, a tradição derviche ${ }^{245}$ costuma falar em Via do Amor e Via do Conhecimento. Seria um equívoco, porém, supor que se trata de vias excludentes ou mesmo diversas: na realidade, um mesmo mestre pode ser visto como pertencendo a uma ou a outra, dependendo do modo como seu lugar é visto na economia do sufismo ${ }^{246}$.

\footnotetext{
245 O derviche é o "buscador da Verdade", aquele que está no Caminho sufi.

${ }^{246} \mathrm{O}$ fato de que Ibn 'Arabî é também conhecido como al-sultan al-arifin (o sultão dos gnósticos) e Rumi como al-sultan al-hubbiyun (o sultão dos amantes) não contradiz o que estou dizendo e, muito menos, significa, como alguns gostariam de pensar, que este seja "mais amoroso" enquanto aquele "mais intelectual", o que atesta uma ignorância abissal a respeito do Sufismo. Lembremos o famoso poema de Ibn 'Arabî em que ele declara: "eu sigo a religião do amor" ou "Por Deus, experimento o amor a um ponto tal que, pareceme, os céus se deslocariam, as estrelas se apagariam, as montanhas tremeriam se dele eu lhes encarregasse: tal é minha experiência do amor..." "Par Dieu, j'éprouve de l'amour à un point tel que, me semble-t-il, les cieux se disloqueraient, les étoiles s'effaisseraient, les montagnes s'ébranleraient si je leur en confiais la charge: telle est mon expérience de l'amour..." (cit e trad. por Addas, Claude, Expérience et doctrine de l'amour, op. cit.).
} 
Num banco do jardim em frente à mesquita, um fiel descansa sob o sol. Os padrões geométricos desenhados no portal da entrada contrastam, por um lado, com a aspereza da terra seca do chão batido e, por outro, com a eloquência contrapontística das rosas bem cuidadas do jardim. Seu corpo sentado em repouso nunca aprendeu a tornar-se abstrato das situações. Ao contrário, ele está aí e participa da polifonia desse momento inteiramente silencioso. Quem respira não é esse corpo, é esse momento. É o momento que está vivo. Nos últimos tempos, esse homem tem experimentado algumas dificuldades e, recentemente, habituou-se a meditar sobre elas nesse jardim público, que ele chama de "lugar de cura". De fato, depois de um tempo de meditação, ele se sente menos amarrado pelos problemas, mais distante e, portanto, com mais clareza. Seu movimento de acoplamento com esse espaço harmônico o retira da tensão e da estreiteza dos antagonismos.

No Mundo Encantado, esse espaço não é físico, é imaginativo. Além da harmonia física resultante dos elementos presentes, há a realidade imaginal do "Ele te vê". Há um campo sutil estabelecido pela "conversa íntima" do fiel com Ele. Essa conversa, entretecida pelo ritual fixo, repetitivo, ritmado e rimado da reza, dá-se como uma mistura de planos de realidade: ele repete um certo número de vezes um Nome divino ou um verso do Corão, ou recita uma oração; enquanto isso, uma parte de sua mente distrai-se e viaja por cenas e sentimentos recentes, às vezes trazendo à memória fatos distantes, às vezes longos diálogos internos, suas dificuldades começam a dizer-se. Os planos de realidade formam tramas evanescentes na urdidura da reza, sua vida dança em torno da harmonia da Lei. Aos poucos, tudo nele é imaginação em ato - as respostas de Deus: os planos de realidade emergem renovados de seu mergulho na Escrita da Lei trazendo novos contornos, novas formas, novos lugares possíveis, imagens de uma realidade mais real porque imaginada. Imaginada porque houve um distanciamento, um acoplamento com o Outro, um alargamento, um encontro com algo de outra ordem. Finalmente, uma trama pousa, agora mais definitiva - na urdidura daquele espaço de cura. Ele desperta e volta para casa munido de uma vida lavada.

A imaginação sendo, nesse caso, um modo de desidentificação de si pela identificação com o Outro. No ego, estão as imagens amarradas pela identidade, pelos limites de uma história abstrata. No Outro, estão as imagens dos possíveis. Não se trata de imaginar soluções de problemas, trata-se de conceber outros lugares, outros modos de ser. Mas, não simplesmente outros modos de ser como uma necessidade fortuita de variação. Outros modos de ser que possuam uma concretude, isto é, uma harmonia com o atual, uma conversa íntima com o momento, uma verdade própria daquela pessoa, naquele momento e naquele lugar.

Um manual de erotismo do séc. $X 1^{247}$ ensina as práticas e as orações a serem feitas pelos amantes durante o ato sexual. Essas técnicas habilitam o amor imaginativo e abrem os amantes ao "Ele te vê". A dança dos diversos planos de realidade - o desejo, a excitação, as distrações, os medos, os vícios, as suspeitas, as histórias - constrói-se em torno da ur-

${ }^{247}$ Cf. Luce Lopez Barault, Un kama sutra espanhol, op. cit. 
didura do ritual. O fixo e o mutável, rigor e flexibilidade, o caleidoscópio de uma entrega passiva penetrada por construções ativas. Arte e ciência, sexo técnico, amantes secretamente mortos a este mundo.

O olhar do Maior e do que está entre o sujeito e o outro - uma situação, uma pessoa, um objeto - interfere tanto no "um" quanto no "outro". Dito de outro modo, a cada momento, o "um" é uma trama e o "outro" é outra trama, mas a urdidura que pode construir-se entre eles propõe uma trama entre eles. Ao tramar juntos, eles se desconstróem. Quando Allâh vê, uma realidade nova é inaugurada.

Em seu estado bruto e sem trabalho, o ego quer ser visto de um certo modo, ele busca identificar no olhar do outro a trama que ele quer ser para o outro e, se ele a encontra nesse olhar, ama o outro, se não, o combate.

Fábio Ramazzina, músico e concertista de violão, explicou-me um dos modos da dimensão imaginativa do seguinte modo. O músico instrumentista desenvolve uma convivência íntima com o seu instrumento de tal modo que, habitualmente, seu corpo aprende a amoldar-se ao formato do instrumento. Exemplificando com o violão, Ramazzina explica que o violonista, muitas vezes, precisa, de modo harmônico, aprender a torcer o próprio corpo a fim de extrair a melhor performance. No entanto, diz ele, o momento chave é quando se aprende a torcer o violão.

Em outra perspectiva, com violência clara ou dissimulada, o ego busca torcer o outro porque o outro não se emancipa como independente de sua construção egóica. O outro faz parte, é complemento, não é realmente "outro". O ego torce o outro - seja esse outro o seu corpo, a sua profissão, o dono da padaria ou um político ou um companheiro - a fim de que ele se amolde ao seu discurso. Mas é possível torcer o outro de um outro modo.

Torcer o violão é uma atividade da imaginação, torcer uma pessoa é uma atividade da ilusão e da violência, a menos que se torça a pessoa como o Ramazzina torce o violão.

No olhar de Deus, o "um" não encontra uma trama, e sim uma urdidura. Portanto, o trabalho do ego é orar como se visse o seu Senhor, de modo a dar-se conta de que "Ele o vê", isto é, que Ele vê uma urdidura em vez de um ego. A imaginação é a contemplaçãoconstrução da(s) própria(s) urdidura(s).

Nessa perspectiva, quando o "um" olha para o "outro" como se o visse, abrindo-se para o "ele te vê" do outro, há um instante de perplexidade pois nenhum dos dois tem posta uma imagem. Há uma aposta antes de uma resposta. Há uma invenção antes de uma investigação. Há um resultado antes de um processo, o fruto antes da semente. O amor é essa proposta inaugural e inauguradora. Imaginar que é possível ver o outro e que é possível que "ele te veja" é, pelo entre olhares, lançar-se ao possível de onde inauguram-se as tramas. 
O espaço público simbólico é esse espaço imaginativo, espaço técnico de alargamento, de desidentificação de posições imaginárias e de afastamento dos discursos, espaço político de decisões em comum acerca do incomum, espaço público, não privado nem privativo, de emancipação do outro, de criação do outro, de amor ao outro.

Imaginar, portanto, não é criar formas, nem fantasiar, nem buscar alternativas, nem sair do convencional, nem inovar. Imaginar é denarcisar e é inundar-se do atual.

Não se trata do não-lugar da utopia. Ao contrário, tudo é lugar. Claire de Lune aconteceu num lugar chamado Debussy. O homem, diz Ibn 'Arabî, é um lugar (mazarar) de manifestação de Nomes divinos. O "um" é lugar de pouso do "outro" e vice-versa.

Voltemos à questão do capítulo 2.8, "A realidade como linguagem".

Tratar o outro como linguagem é imaginá-lo em urdiduras. Algumas pessoas são capazes de distinguir, entre atores, uma performance ruim de uma boa. Outras pessoas, por exemplo, são incapazes de distinguir um Bach de um Wagner. No caso anterior, percebem o trabalho do ator como uma linguagem, no segundo, não percebem a música como tal. Se quiserem, podemos dizer que, no segundo caso, a pessoa em questão é "burra para a música".

Podemos dizer, acerca de uma pessoa que não se relaciona com a música como linguagem, que, quando essa pessoa flerta com a música, esta não lhe dá ouvidos. Ela acena, faz caras e bocas, imagina que está agradando, porém, não atinge o alvo. Nada, vindo de lá, responde-Ihe. Claro está que a pessoa pode fingir - consciente ou pré-conscientemente uma resposta. Ingenuamente, ela creditará qualquer pequena impressão como resposta, ela poderá crer-se "alguém de bom gosto musical", "sensível" ou mesmo - que limites há para a auto-ilusão? - "um expert". Pouco importa, o fato é que, por parte da música, não há resposta. Não há amor possível.

"O Corão é como uma jovem recém-casada; mesmo que tentes levantar seu véu, ela não se mostrará a ti. Se discutires o Corão, nada descobrirás, e nenhuma alegria te chegará. É por teres tentado levantar o véu que o Corão se recusa a ti; empregando esperteza e fazendo-se feio e indesejável a teus olhos, ele te diz: não sou aquele que amas. Ele pode, portanto, mostrar-se sob qualquer ponto de vista." 248

Quando uma pessoa trata o outro como uma linguagem - seja esse outro um tipo de arte, uma idéia, uma coisa qualquer ou uma pessoa -, todo o processo se dá. Há flerte e resposta. Há sedução, brincadeira, tentativa e erro, sendo que as tentativas são talentosas, não estúpidas: porque, mesmo que sejam estúpidas, são feitas a partir de um lugar de ensaio, de proposta, não de imposição. São descoladas.

\footnotetext{
${ }^{248}$ Rumi, trad. e cit. por Schuon, in Comprendre L'Islam, op. cit., p. 49.
} 
Em termos pedagógicos, ao definirmos o talento como a habilidade de lidar com um outro como se fosse uma linguagem, põe de imediato a busca de modelos que transitem por essa construção intencional do outro como linguagem. Se o outro é uma questão política ou afetiva ou estética, tratá-lo como linguagem significa, por um lado, acoplar-se com o tempo, o lugar e as pessoas, por outro, descolar-se dos discursos, por outro ainda, imaginar, aprender e agir.

Nesse sentido, todo modelo deve consistir na construção de urdiduras, no trabalho sobre as marcas, no exercício dos mais diversos modos da invisibilidade. Há alguns tipos de invisíveis que são estruturas de linguagem. Quando se ensina música ou língua, por exemplo, muitos modelos lidam com estruturalidades. Mais recentemente, buscam-se abordagens "estruturais" de outras "matérias". Futuramente, há que se imaginar que as fronteiras entre as "matérias" escolares cairão como caiu o muro de Berlim e que um pensamento em trânsito será comum na pedagogia. Urdiduras desse pensamento, então, estarão em pauta. Como vimos no capítulo 2.12, como "estruturalidade pedagógica", a ciência da cortesia é uma urdidura da aproximação com o outro e a ciência imaginativa, uma urdidura do aprendizado com o outro.

A atividade humana na cena pública - a arte, a pesquisa, a ciência, a reflexão, os encontros - urdida pela imaginação, tem como propósito esse despropósito, esse alargamento, essa desmedida. Ao mesmo tempo, ao dar-se à cena pública, ela se torna medida para outros que nela transitarão para transbordar-se. Daí ser espaço, daí ser público e daí ser simbólico.

\subsubsection{ESPAÇO PÚBLICO E MITO FUNDADOR}

Claro está que a expressão "espaço público", em sua acepção usual, tornou-se limitada perante o que está em jogo. Desse modo, ela também sofre aqui um alargamento. O "público" não sendo apenas o lugar jurídico do que se opõe ao privado, mas sendo o lugar do Outro, cenário de acolhimento da diferença - não apenas diferença psicossocial mas, sobretudo, diferença linguística: acolhe-se neste espaço tudo o que permite ser tratado como linguagem.

Perguntaram-me uma vez se o modelo caleidoscópio "representaria uma rejeição do construtivismo, dada a ênfase deste último na racionalidade". Novamente, o hábito antagonista. É fácil ver que a "inspiração" estruturalista corresponde a boa parte da perspectiva aqui trabalhada, o sujeito "não terminado" sendo um de seus fundamentos. É verdade que toda a idéia de construção elaborada por Piaget, além da ênfase na lógica, é bem menos radical que a idéia de um caleidoscópio que pensa uma flexibilidade integral das estruturas de conhecimento e de esperiência. Mas essa radicalidade reside justamente na consideração da estrutura, a partir de Derrida, como arranjos e combinatória e, a partir do sufismo, como renovação singular e intencional, portanto, como capacidade de linguagem. Assim, além do construtivismo ser um ponto de partida, é preciso considerar que, se ele 
pode ser trabalhado como uma linguagem, então, como qualquer outra, ele é o modelo caleidoscópio.

Resta abordar um outro aspecto da idéia de espaço público como lugar de linguagens. Ao estudar um dos aspectos cruciais da ideologia - entre os que me permitem tratá-la como estrutura e como "pseudo-Outro" -, Marilena Chauí explica a noção de mito fundador.

Ao falarmos em mito, nós o tomamos não apenas no sentido etimológico de narração pública de feitos lendários da comunidade (isto é, no sentido grego da palavra mythos), mas também no sentido antropológico, no qual essa narrativa é a solução imaginária para tensões, conflitos e contradições que não encontram caminhos para serem resolvidos no nível da realidade.

Se também dizemos mito fundador é porque, à maneira de toda fundatio, esse mito impõe um vínculo interno com o passado como origem, isto é, com um passado que não cessa nunca, que se conserva perenemente presente e, por isso mesmo, não permite o trabalho da diferença temporal e da compreensão do presente enquanto tal. Nesse sentido, falamos em mito também na acepção psicanalítica, ou seja, como impulso à repetição de algo imaginário, que cria um bloqueio à percepção da realidade e impede lidar com ela.

Um mito fundador é aquele que não cessa de encontrar novos meios para exprimir-se, novas linguagens, novos valores e idéias, de tal modo que, quanto mais parece ser outra coisa, tanto mais é a repetição de si mesmo.

Insistimos na expressão mito fundador porque diferenciamos fundação e formação.

Quando os historiadores falam em formação, referem-se não só às determinações econômicas, sociais e políticas que produzem um acontecimento histórico, mas também pensam em transformação e, portanto, na continuidade ou na descontinuidade dos acontecimentos, percebidos como processos temporais. Numa palavra, o registro da formação é a história propriamente dita, aí incluídas suas representações, sejam aquelas que conhecem o processo histórico, sejam as que o ocultam (isto é, as ideologias).

Diferentemente da formação, a fundação se refere a um momento passado imaginário, tido como instante originário que se mantém vivo e presente no curso do tempo, isto é, a fundação visa a algo tido como perene (quase eterno) que traveja e sustenta o curso temporal e lhe dá sentido. A fundação pretende situar-se além do tempo, fora da história, num presente que não cessa nunca sob a multiciplicidade de formas ou aspectos que pode tomar. Não só isso. A marca peculiar da fundação é a maneira como ela põe a transcendência e a imanência do momento fundador: a fundação aparece como emanando da sociedade (em nosso caso, da nação) e, simultaneamente, como engendrando essa própria sociedade (ou a nação) da qual ela emana. É por isso que estamos nos referindo à fundação como mito.

O mito fundador oferece um repertório inicial de representações da realidade e, em cada momento da formação histórica, esses elementos são reorgani- 
zados tanto do ponto de vista de sua hierarquia interna (isto é, qual o elemento principal que comanda os outros) como da ampliação de seu sentido (isto é, novos elementos que vêm se acrescentar ao significado primitivo). Assim, as ideologias, que necessariamente acompanham o movimento histórico da formação, alimentam-se das representações produzidas pela fundação, atualizando-as para adequá-las à nova quadra histórica. É exatamente por isso que, sob novas roupagens, o mito pode repetir-se indefinidamente. ${ }^{249}$

Quando pensamos nos permanentes diálogos que os sujeitos realizam consciente e inconscientemente com o Outro, podemos nos perguntar como, nesse diálogo, interfere o mito fundador, cuja conceituação feita por Chauí permite a articulação entre uma perspectiva psicanalítica - a captura imaginária "que cria um bloqueio à percepção da realidade e impede lidar com ela" - e uma crítica à ideologia - que vê na fundação um conjunto de representações que ocultam o processo histórico.

Criador de um pseudo-Outro, o que o mito fundador oculta, em última análise, é justamente o Outro, não somente impedindo o árduo exercício deste diálogo mas, sobretudo, usurpando-lhe as respostas.

Surdo à realidade, o sujeito passa a dialogar com a Nação, com "n" maiúsculo, como se dela legitimamente emanasse o conjunto de leis e critérios com os quais ele se representa ser e estar dentro dela. Ele pode discordar dos governantes, das políticas públicas, mas a poucos ocorreria descolar-se por inteiro da nação e declarar-se, como queria Hannah Arendt, um indivíduo internacional.

Na microfísica do poder, vemos seu próprio corpo legislado por uma fundação que lhe impõe o Mesmo no lugar do Outro, de modo que seu trabalho de construção de si, em vez de fazer-se dentro dos embates que ele poderia propor entre sua herança simbólica - os materiais linguísticos disponíveis em sua época - e a realidade atual, torna-se, inversamente, a criação de mitos pessoais que imitam as estruturas do mito fundador e, pela mesma via, mascaram o fato de que o sujeito, no dizer de Riobaldo, ainda não foi terminado e fazem crer, como vimos, que ele seja dotado de uma "personalidade", fundada e cristalizada na origem, isto é, na infância, lugar decisivo onde os destinos são fundamentalmente traçados.

Daí a importância de se ter "uma infância feliz".

Pensando psicanaliticamente, é perfeitamente natural conceber a infância como um período dolorosíssimo, votado ao aprendizado do conflito como constitutivo desse ser em transformação, do conflito como via, como atravessamento das marés de saber e nãosaber, das estações de plantio e colheita do previsto, das tempestades do imprevisto e dos diálogos noturnos com o imprevisível. Infância, portanto, como história da conquista da

${ }^{249}$ M. Chauí, Brasil: mito fundador e sociedade autoritária, op. cit., pp 9-10. 
dor para o campo do trabalho sobre a dor. Sendo, então, "feliz" a criança que pode contar esta história, a sua história.

No entanto, não é, obviamente, esta a idéia oficial que a Nação tem da felicidade. $E$, do mesmo modo como o mito fundador percola-se a toda a sociedade, manifestando-se tacitamente nas representações dos mais variados grupos e associações, ele também dá fundamento aos processos de exclusão. Dentre estes, poucos são tão claros quanto os que objetivam aqueles que não podem ter "uma infância feliz".

A exclusão, nesse sentido, é uma posição perante o mito: há as crianças cuja biografia pode servir à representação de uma história do Mesmo, cuja história é a mesma das crianças normais, e há as crianças cuja história é outra - por exemplo, as provenientes das chamadas famílias desestruturadas, cujo pai ou mãe estão na prisão, são dependentes de drogas, etc. - igual às de outras crianças que diferem das normais, as crianças que, a priori, não podem ser felizes porque as condições materiais, afetivas e intelectuais das quais depende a felicidade normal não estão presentes. E esta posição é igualmente fundante.

Pertencer à Nação significa poder orgulhar-se de ter nascido porque é este lugar onde se nasce que faz de cada um o portador da "identidade nacional". Porém, nascer numa família "desestruturada" é lembrar à Nação aquilo de que ela não pode orgulhar-se. O mito fundador da realidade das crianças de rua, dos jovens judicializados, é o de serem vítimas irrecuperáveis. É importante, então, questionar esse mito como o vêm fazendo várias iniciativas de trabalhos realizados em comunidades.

Com essa finalidade, o espaço público é pensado como um espaço de cruzamento entre histórias: o desvendamento de processos históricos que compõem as histórias dos povos trama-se entre as histórias de cada outro. Neste contexto, o espaço público simbólico tem como cenário inicial a seguinte indagação: se é possível passar do mito à história, se acreditamos que qualquer pessoa, criança ou adulto, pode contar a sua história, se podemos buscar atravessar os véus que nos ocultam a História e as histórias, como fazê-lo em uma experiência concreta, junto a uma instituição concreta e a partir da história concreta desta instituição?

Eis um ponto de partida: qual a história de uma instituição? Que histórias ali podem contar-se os seus membros (crianças, pais, educadores, administradores, pesquisadores, enfim, trabalhadores em todas as funções)? Que espaço público podemos construir juntos de modo que as histórias se apresentem nas pedras do chão, no ar das janelas, na roupa, nas lâmpadas, nas vozes e no silêncio que as pessoas dão à luz neste lugar? Que indagações dirigem ao Outro estas pessoas, porque falam ao seu tempo, ao seu país, aos seus governantes, aos seus outros?

O que é, então, o espaço público simbólico? É o espaço antiinstitucional por excelência, do não instituído, do por fazer-se, das histórias e da História, dos processos, das construções e do abandono das construções. 
Aqui é preciso atenção: não se trata de contar histórias da própria vida como um exercício narcísico de "autoafirmação", para ser "valorizado pelo outro", para "aumentar a autoestima por meio da escuta do outro". Assim como não se trata de biografia, de contar fatos ou de descrever sentimentos ou "experiências pessoais" nem de confessar publicamente aqueles acontecimentos que a ideologia chama de tragédias ou de sofrimento. Não se trata de vender narrativas em troca de afeto, emoção ou excitação. Não se trata de contar histórias para "sentir-se melhor", para "ver o lado positivo das coisas", para "desenvolver virtudes". Não se trata de contar histórias para afirmar uma identidade, um passado, uma "diferença", uma "tolerância ao outro" como se o outro fosse cristalizadamente diferente, preso em seu passado, como se todos não fossemos perenemente outros.

A história é sempre processo de desvendamento e de travessia pela Vasta Terra da realidade. Trata-se de história como linguagem de construção de linguagens. Trata-se de navegar por veredas de um imenso sertão, deixando-se levar por um rio de discurso que não é abstrato da paisagem porque a vereda é o sertão e o sertão é a vereda, verdades a seus modos. Além de lembrar que o sertão, ao olhar distraído, não parece perigoso. Mas é.

Pela via do Encantamento, os homens buscam imitar o Corão, buscam construir urdiduras e não apenas tramas. Buscam ensinar às suas crianças que elas podem torcer o violão. Que elas podem mudar de lugar, assim como o trono da rainha de Sabah foi transportado até Salomão - e isso é uma operação simbólica. Que elas também podem parar para pensar, suspender-se da viagem por um momento e olhar o céu para ver se é essa rota que querem seguir ou se agora preferem outra, descolando-se dessa - e essa é uma operação imaginária. Buscam sugerir-lhes que elas são ninguém e, portanto, podem inundar-se do Misericordioso (ar-Rahmân) e exalar o Seu hálito emancipador.

Dentro deste mundo há outro mundo impermeável às palavras.

Nele, nem a vida teme a morte, nem a primavera dá lugar ao outono.

Histórias e lendas surgem dos tetos e paredes, até mesmo as rochas e árvores exalam poesia. Aqui, a coruja transforma-se em pavão, o lobo, em belo pastor.

Para mudar a paisagem,

basta mudar o que sentes;

e se queres passear por estes lugares, basta expressar o desejo.

Fixa o olhar no deserto de espinhos. Já é agora um jardim florido! Vês aquele bloco de pedra no chão? Já se move e dele surge a mina de rubis!

Lava tuas mãos e teu rosto nas águas deste lugar, que aqui te preparam um fausto banquete. Aqui, todo ser gera um anjo; e quando me vêem subindo aos céus os cadáveres retornam à vida.

Decerto viste as árvores crescendo da terra, mas quem há de ter visto o nascimento do

Paraíso?

Viste também as águas dos mares e rios, mas quem há de ter visto nascer de uma única gota d'água uma centúria de guerreiros? Quem haveria de imaginar esta morada, esse céu, esse jardim do paraíso?

Tu, que lês este poema, traduze-o. Diz a todos o que aprendeste sobre este lugar.

(Jallaludin Rumi) $^{250}$

${ }^{250}$ Poemas Místicos, op. cit., p. 54. 
210 


\section{PARTE 3: PROBLEMAS DAS TIPOLOGIAS (OU ESTRUTURALIDADES)}

Uma amiga me mostrou esse precioso depoimento de uma das crianças de uma escolinha, num desses "feedbacks" que elas são obrigadas a dar todo ano:

"A minha escola é pequena, mas muito bem arranjada. A minha escola é como se fosse um jardim, nós, os alunos somos as flores e

a senhora professora é como se fosse um monte de estrume que nos faz crescer belos e fortes." 
212 


\section{1 "NÃO CRIAMOS EM VÃO O CÉU, A TERRA E O QUE EXIS- TE ENTRE ELES." (COR. 38:27) $)^{251}$}

Se o singular corresponde à experiência do atual e do único, ao que constantemente se renova, ao contato direto com o Um, para quê serve o múltiplo? Para quê o mundo, se se trata de buscar a via direta entre o homem e Deus?

Retomo algumas formulações anteriormente feitas aqui. Incialmente, a relação fundamental entre Singularidade e Totalidade. A metáfora do caleidoscópio, como vimos, permite pensar, por exemplo, a intuição - que é a faculdade do singular - não apenas como um insight, como um acontecimento interior de entendimento dentro de uma totalidade, mas, sobretudo, como uma nova totalidade: mexemos o caleidoscópio e não apenas um dos elementos se modifica mas, sim, a totalidade do arranjo. Isto é, não se trata de ter uma intuição acerca de alguma coisa, trata-se de uma modificação integral daquele que percebe e do que é percebido a cada intuição. Ou seja, dependendo da "profundidade" da intuição, há uma mudança de posição imaginária ou simbólica ou mesmo uma "morte" radical do ego. Nesse caso, há uma espécie de identidade entre singular e total.

Numa outra perspectiva, a totalidade é vista como uma linguagem e a singularidade como a atualização no sujeito de uma nova combinação dentro da linguagem. Num caso, a totalidade é vista como uma urdidura e os rearranjos como uma nova urdidura, noutro, os rearranjos são novas tramas.

No caso do moleque bom de bola, a totalidade é o futebol como jogo, como campo gramado com marcas no solo, traves e rede, como time e como time adversário, como torcida, como aquele jogo, naquele dia, com aquelas pessoas. A bela jogada é o resultado de

\footnotetext{
${ }^{251}$ Os versos 3:190-1 dizem o seguinte: "Em verdade, na criação dos céus e da terra e na alternância da noite e do dia, há certamente sinais para os dotados de inteligência que, de pé, sentados, deitados, invocam Allah e meditam sobre a criação dos céus e da terra (dizendo): Senhor nosso, não criaste isso em vão. Glória a Ti! Preserva-nos do castigo do fogo."
} 
tudo o que ele tem tramado em seus treinos e em sua imaginação. Ela depende de sua capacidade de integrar-se e entregar-se à totalidade, à urdidura do futebol concreto. A bela jogada, muitas vezes aquela que ninguém percebeu porque não percebe o que o moleque percebe de sua experiência, é o seu momento singular, seu contato com o Um.

Estabelecendo uma dualidade operativa, podemos dizer que esse momento singular é a vertical e que a urdidura do futebol é a horizontal ${ }^{252}$. Nesse caso, diremos que a relação com o Um depende da urdidura ou da totalidade do futebol, portanto, que a vertical depende da horizontal.

Se pensarmos a totalidade com o mesmo sentido que o termo "multiplicidade" tinha para, por exemplo, uma metafísica medieval cristã, isto é, como "mundo" em relação a Deus, o mundo será, para nós, a totalidade. Nesse caso, o mundo é o caleidoscópio em permanente rearranjo. Como vimos, por obra do Mundo das Analogias, todas essas realidades são intercambiáveis entre si. Tudo o que é múltiplo é visto como totalidade porque é visto como um conjunto de relações. Isto é, não se trata de uma lista múltipla aleatória, trata-se de um todo organizado segundo parâmetros.

Assim, podemos dizer que a relação singular do homem com Deus depende do mundo.

Um dos problemas desse tipo de equacionamento reside no risco de que isso se torne uma abstração. Numa certa perspectiva, a distinção Deus, homem, mundo é importante para certas operações, numa outra, ela sequer faz sentido, portanto, não se trata de fixála. Concretamente, estou construindo relações de necessidade entre a singularidade e a totalidade.

O mundo não foi criado em vão. Como o amante que só vê o Amado, o homem turbado e perplexo diante do arrebatamento do singular parece tomar o mundo como um estorvo a desviá-lo de seu Único desejo. O coração parece querer livrar-se das amarras do ego, a intuição parece desprezar a razão, o movimento parece detestar as coisas "fixas", as estruturas, as organizações, as estrelas e a Lei. Todo o meu esforço ao longo do presente trabalho foi o de construir a visão na qual não há antagonismo entre estes termos. A Lei é a estruturalidade do movimento, o ego é o dizer-se do coração, o mundo é Deus em palavras.

Parafraseando Lacan, o homem e o mundo estão estruturados como linguagens. Pensar o homem e o mundo como estruturalidades é vê-los como caleidoscópios. Ver estruturalidades no homem é construir tipologias. Várias questões abrem-se aqui.

Tratarei, inicialmente, de uma tipologia vista pelo Encantamento. Em seguida, proporei algumas conexões com certas estruturas contemporâneas que podem receber um tratamento "tipológico" específico.

\footnotetext{
252 Importante lembrar: numa outra montagem, podemos dizer exatamente o contrário ou podemos colocar a urdidura como vertical e a trama como horizontal e assim por diante. Ver cap. 2.10.
} 
A lei é uma e uma para cada um. Do mesmo modo que a segunda parte desta frase, "e uma para cada um", corresponde à singularidade, a primeira, "a lei é uma", corresponde à uma ciência tipológica.

Um dos principais problemas das tipologias é que, no ambiente dos nossos hábitos mentais, elas rapidamente se transformam em "fixidez". Como se confundíssemos a todo momento os planos da trama e da urdidura. Uma tipologia deveria funcionar como uma urdidura no sentido de orientar construções, orientar os trânsitos de uma pessoa, arar campos. Situar-se dentro de um certo tipo não é o mesmo que poder dizer: "eu sou assim". É uma forma de ir em busca de grandes critérios operativos, é uma construção de andaimes. O que me parece um caminho promissor no contexto da busca de um modelo pedagógico é combinar tipologias diversas de tal modo que, por um lado, logramos algum sucesso na tentativa de evitar a "fixação" e, por outro, enriquecemos nossa experiência a partir de múltiplos referenciais.

Portanto, retomando o que foi dito, o caleidoscópio aqui é um marco do trabalho: não se trata de dizer que a idéia de que tudo está em movimento opõe-se à idéia de uma urdidura fixa, ao contrário, o movimento está no constante rearranjo das urdiduras, a harmonia residindo na profusão das estruturalidades. Do mesmo modo, a singularidade não se opõe à tipologia, que, no caso, não corresponde a uma identidade mas, sim, a um modo de funcionar.

Obviamente, não penso aqui em trabalhar com tipologias desencantadas, isto é, aquelas, dentro da psicologia positivista, que foram elaboradas a partir de métodos científicos modernos.

Numa pedagogia encantada, a tipologia é como um guia para o trabalho educativo. Não se trata de dizer que, conforme o mapa astrológico de uma criança, devemos esperar ela se comporte de tal ou tal jeito, tenha tal ou tal desejo, etc. Isso seria uma aberração! O que podemos fazer é observar o seu processo de construção de significações, tendo em mente a estrutura vazia do seu mapa natal ${ }^{253}$. O leitor há de compreender que esta é uma vasta questão, a exigir uma tese particular para tratá-la. Tanto mais pela série de equívocos graves que ela pode gerar - e de fato gera - pela utilização de um pensamento encantado sob os hábitos mentais do positivismo moderno. Portanto, meu intuito ao registrá-la é, antes de tudo, falar de um campo de possibilidades de pesquisa.

Se pensarmos com a estruturalidade da medicina chinesa, por exemplo, temos que uma criança que apresenta uma certa coloração de olheiras, certos sinais na língua, um certo pulso e sente medo numa certa hora do dia, mostra que necessita de um certo tipo de alimento ou de prática corporal. Trata-se de uma linguagem que conhece os movimentos dos órgãos ou dos fluxos energéticos corporais e anímicos.

\footnotetext{
${ }^{253}$ Em meu livro Sentidos do Caleidosópio, op. cit., no capítulo "Por uma epistemologia da ciência tradicional", tratei de questões epistemológicas acerca da astrologia. As considerações que se seguem sobre o assunto no presente contexto, dispensam, portanto, tais explicações.
} 
De um modo muito mais desencantado, porém não menos rico, a homeopatia estabelece traduções entre a linguagem das substâncias e os discursos dos pacientes. O remédio, nesse caso, é uma proposta de significação a ser trabalhada - experimentada, acoplada e percolada - pelo paciente.

No entanto, há um uso reducionista das tipologias que pode acarretar em diversos malefícios. Se alguém se refere a uma mulher, numa determinada situação em que ela se encontra indignada e manifestando sua ira em altos brados, como "uma histérica", o termo corresponde a uma adjetivação comum e corrente, às vezes um xingamento, sem maiores pretensões "científicas". No entanto, quando vemos, como eu vi, uma professora de Psicanálise afirmar em aula, numa faculdade, que as atrizes são histéricas porque gostam de se exibir, a coisa muda de figura e torna-se uma grave vulgarização da matéria. Do mesmo modo, quando um homeopata refere-se pejorativamente a alguém dizendo que ele é "um nux vomica", afirmando tacitamente com isso que se trata de um "neurastênico", ou quando um acupunturista sente desprezo por alguém que come açúcar demais, estamos diante do velho problema dos hábitos mentais fundamentalistas, que confundem crítica com julgamento - e às vezes, com "juízo final" - e alimentam, de modo tácito ou explícito, processos de exclusão de toda ordem.

As tipologias recortam grandes conjuntos de cenários nos quais podemos vislumbrar recursos para as mais variadas faculdades cognitivas: a reflexão, a imaginação, a intuição, o sentimento, a sensação, etc. Esses recursos se formam a partir de técnicas que deveriam estar à disposição em um modelo pedagógico.

Quando penso em "trazer de volta" a astrologia, meu propósito é investigar esta ciência e ver como ela pode ser útil hoje, isso porque a perspectiva é resgatar o que for possível do Encantamento e de sua incrível engenhosidade.

\subsubsection{O PENSAMENTO ANALÓGICO COMO ESTRUTURALIDADE}

Como vimos na Parte 2, o homem é o intérprete da realidade. Recuperando a dualidade operativa formada pelo par "ego e coração", podemos dizer que as interpretações podem ser "egóicas" (abstratas, generalizadoras, ideológicas, etc.) ou, "inversamente", atravessadas por uma busca de singularidade, isto é, uma busca na qual o ego é trabalhado para desidentificar-se de suas posições abstratas, para se autoobservar e se autocriticar, para esvaziar-se de seus hábitos mentais condicionados e para buscar estabalecer uma relação com as situações enquanto linguagens, para construir aproximações destas linguagens por meio de acoplamentos, de percolações e de uma mentalidade de pesquisa de tal modo que se trata de harmonizar-se com a linguagem e de tentar, ao máximo, tornar-se esta linguagem e, ao sê-la por inteiro, "receber" a intuição que lhe propicia, por meio da imaginação, criar ou atualizar algo de dentro dela a partir do próprio desejo singular. São dois processos diferentes de interpretação (ou de significação, pois, aqui, estes termos tornaram-se sinônimos). 
Como se trata de uma dualidade operativa, devemos lembrar que não pretendemos estabelecer um antagonismo entre os pares. Ao contrário, trata-se de saber de antemão que há constantes travessias entre a interpretação egóica e a singular, como já vimos.

Assim, um dos propósitos do Modelo Caleidoscópio é desenvolver estruturas complexas de significação, que envolvam diversos aspectos tanto da situação quanto do(s) intérprete(s). Trata-se de um modelo de traduções em níveis diversos e múltiplos.

O pensamento analógico é o que torna todas essas coisas factíveis. Estabelecendo analogias entre linguagens:

- percebemos o que é linguagem, isto é, não definimos linguagem, nós nos acoplamos corporalmente com estruturas analógicas e passamos a pensá-las assim;

- somos capazes de transitar por entre linguagens e de descolar-nos de cada uma, construindo movimentos de desapego;

- somos, portanto, capazes de mudar de lugar, criando novos processos de significação;

- rompemos o vínculo com a lógica ocidental como única via de transmissão de conhecimento;

- trabalhamos com tipologias como linguagens, isto é, como estruturas pelas quais transitamos a fim de mudar de lugar e de elaborar processos complexos de significação;

- trabalhamos o espaço público como uma linguagem, o que faz com que ele não seja feito de indivíduos concebidos abstratamente, mas, sim, de gente em construção e em relação constante;

- trabalhamos a relação com o Mistério e a Lei como linguagens, de modo que passam a ser estruturas vivas, falantes, variáveis conforme o tempo, o lugar e as pessoas. 
218 


\subsection{UMA TIPOLOGIA ENCANTADA: A ASTROLOGIA}

\subsubsection{O ZODÍACO COMO MODELO MENTAL}

Numa primeira abordagem, a astrologia como linguagem pode ser tratada como um sistema de organização de modelos mentais. Sendo uma estrutura total, no sentido com que esta idéia foi tratada ao longo do presente trabalho, o zodíaco permite um considerável exercício teórico. Examinemos algumas particularidades de sua estrutura.

O padrão geométrico zodiacal parte de uma relação algébrica simbólica entre os números 3 e 4.

No Mundo Encantado, uma unidade básica do mundo consiste no conjunto dos 4 elementos: o seco, o úmido, o quente, o frio. Da combinação entre eles temos:

\begin{tabular}{r|l} 
seco + frio & terra \\
\hline úmido + frio & água \\
\hline quente + úmido & ar \\
\hline quente + seco & fogo
\end{tabular}

Numa organização "psicológica", temos como possibilidade o seguinte quaternário:

\begin{tabular}{l|l} 
terra & sensação \\
\hline água & sentimento \\
\hline ar & pensamento \\
\hline fogo & intuição
\end{tabular}

Uma síntese dos incontáveis planos da realidade pode ser descrita pelo ternário: denso, sutil e espiritual. Numa organização "psicológica", temos o ternário: corpo, alma, espírito. 


\begin{tabular}{l|l} 
denso & corpo \\
\hline sutil & alma \\
\hline espiritual & espírito \\
\hline &
\end{tabular}

Assim, pela multiplicação de $3 \times 4$, temos as seguintes combinações:

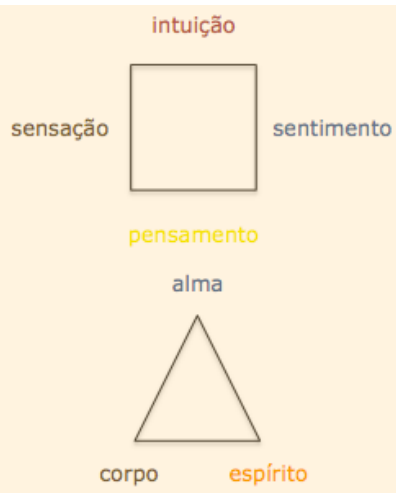

\begin{tabular}{l|c|l} 
áries & $\curlyvee$ & intuição + alma \\
\hline touro & $\sigma$ & sensação + corpo \\
\hline gêmeos & I & pensamento + espírito \\
\hline câncer & $\sigma$ & sentimento + alma \\
\hline leão & $\Omega$ & intuição + corpo \\
\hline virgem & $m p$ & sensação + espírito \\
\hline libra & $\Omega$ & pensamento + alma \\
\hline escorpião & $m$ & sentimento + corpo \\
\hline sagitário & $\nearrow$ & intuição + espírito \\
\hline capricórnio & $\nearrow$ & sensação + alma \\
\hline aquário & m & pensamento + corpo \\
\hline peixes & $\mathcal{H}$ & sentimento + espírito
\end{tabular}

Ou:

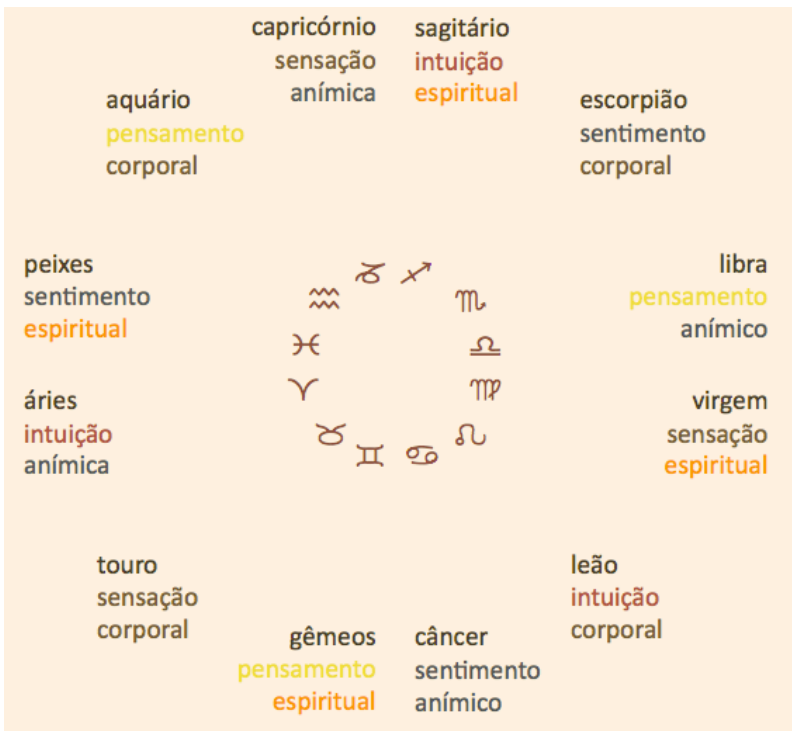

O zodíaco psicológico, visto nessa montagem que acabamos de fazer, seria essa combinação de faculdades cognitivas.

Suponhamos que alguém, uma criança ou um adulto, tenha como tendência, diante de uma determinada situação, utilizar uma certa combinação destas faculdades. Suponha- 
mos que este alguém seja aluno de um professor que tenha por hábito abordar a mesma situação por meio de uma combinação muito radicalmente diferente da sua. Aqui poderíamos supor uma série de consequências possíveis para um problema assim equacionado. No entanto, suponhamos que o professor tem a possibilidade fazer um uso técnico deste "zodíaco".

Ele poderia, talvez, identificar o modo como seu aluno aborda o problema. Nesse caso, ele poderia incentivá-lo a prosseguir nesse modo até extrair consequências satisfatórias para as circunstâncias. Em seguida, ele poderia mostrar outras abordagens, levando técnicas para que o aluno experimentasse outras faculdades.

Com alunos de idade mais avançada, o professor pode trazer questões complexas e atravessá-las pelos ângulos diversos das 12 faculdades. Como se trata de uma totalidade, elas não são aleatórias, isto é, estão integradas flexivelmente dentro de um conjunto: na montagem aqui apresentada ${ }^{254}$, o pensamento se complementa com a intuição, o sentimento com a sensação; há 3 tipos de intuição, 3 tipos de sensação, etc. Ou seja, a articulação entre as faculdades permite que elas se complementem umas às outras de modo que sempre há intercambialidade e movimento, portanto, não há "fixações".

\subsubsection{O ZODÍACO COMO FERRAMENTA ANALÍTICA}

Há pessoas que possuem o hábito de pensar sobre suas ações e buscar critérios, valores e visões de mundo que estejam implicados nelas. Há pessoas que objetam que esse hábito representa um forte risco de racionalização e, como resultado, adquirem o hábito de rejeitar sistematicamente este tipo de procedimento. Há pessoas que veem tanto as primeiras quanto as segundas como "intelectuais", o que pode ser um rótulo positivo ou negativo, dependendo de uma série de razões possíveis, mas que, de toda maneira, é um rótulo. Há pessoas que costumam pensar sobre suas ações baseadas exclusivamente em clichês que aprenderam na escola e na TV.

Todas essas pessoas podem rever seus hábitos por meio da experimentação de faculdades às quais não estão habituadas.

Um dos grandes mitos do senso comum é que os processos mentais são os mesmos para todos. A idéia geral, corroborada pela enxurrada mensal de matérias feitas por revistas dirigidas "à população leiga", é que, se queremos analisar uma questão, utilizamos o pensamento lógico, se queremos fantasiar, utilizamos a imaginação, e assim por diante, o que torna difícil às pessoas observar que, na realidade, nada impede que alguém use a imaginação para analisar e a lógica para fantasiar. Que é exatamente o que ocorre, provavelmente numa frequência espantosa, com resultados os mais variados entre os melhores e os piores.

\footnotetext{
${ }^{254}$ É fundamental que tenhamos em mente que pode haver incontáveis outras montagens.
} 
Alguns estudiosos, ao contrário, produzem listas sobre "os diferentes tipos de pessoas", não sobre os diferentes tipos de faculdades. A lógica é a de sempre: trata-se de classificar pessoas, não de distinguir possibilidades à disposição de todos. Claro está que algumas dessas listas são úteis em determinados casos, no entanto, porque se trata de listas e não de um conjunto estruturado e total, com uma organização interna, a sua utilização é profundamente artificial: ela é fácil para aqueles que possuem boas estratégias para lidar com tarefas e listas, para outros, no entanto, ela exige sacrifícios.

A estrutura zodiacal, por ser uma linguagem, depois de um tempo de trabalho sobre ela, passa a ser, como toda linguagem, algo que funciona em conjunto, um aspecto aludindo continuamente a outro, o que torna seu uso orgânico e harmônico.

Nesse caso, os problemas propostos por um professor podem ser experimentados de 12 ângulos diferentes, o que, no mínimo, é um treino considerável de flexibilidade. Os que se consideram "intelectuais" e os que se consideram "não intelectuais" poderão se dar conta do tempo que estão perdendo com esta categorização tecnicamente estúpida.

\subsubsection{O ZODÍACO COMO FERRAMENTA IMAGINATIVA}

O pensamento analógico permite que cada faculdade cognitiva seja relacionada a um conjunto imenso de experiências.

A faculdade "touro" ou "sensação corporal", por exemplo, refere-se inicialmente ao contato do corpo com as coisas. Analogicamente, porém, refere-se à "tradução" das propriedades dos corpos - forma, densidade, textura, cor, etc. - na experiência interna, isto é, à contrução interna de "corpos", em outras palavras, à imaginação. Nesse caso, sensação, percepção e imaginação são termos análogos entre si e correspondem à mesma faculdade cognitiva.

A faculdade "libra" ou "pensamento da alma" refere-se, numa formulação sintética e ainda sem maiores explicações, ao pensamento do invisível, pois a alma é aquilo que não se vê. Analogicamente, essa faculdade está ligada ao olfato, que é a percepção do que não se vê e, na mesma série analógica, é a percepção do chamado clima de uma situação, como quando alguém diz, por exemplo, "isto não está me cheirando bem". Quando imaginamos uma cena, utilizamos a faculdade imaginativa "touro", porque estamos vendo formas, porém, também estamos "vendo" climas e, nesse caso, diremos que a função é a imaginação sutil, possibilitada pela "libra".

Temos, portanto, nesta montagem, que a imaginação pode ser densa (touro) ou sutil (libra). Como imaginação densa, touro está ligado à beleza, ao sensível, à primavera em seu auge, quando as formas todas vão ao máximo de sua mostração. Como imaginação sutil, libra é a imaginação do outro, que é por excelência o que há de invisível no mundo. Por esta "razão", touro e libra são regidos por vênus, o planeta que, segundo Ibn 'Arabî, ocupa 
a esfera celeste da imaginação e é habitado por José, o profeta que, tanto no Antigo Testamento quanto no Corão, interpretou os sonhos do Faraó ${ }^{255}$.

A partir daí, os trabalhos de construção analógica em torno da idéia do relacionamento com o outro como imaginação sutil ou pensamento da alma e da sensação corporal como imaginação são infindáveis. O leitor familiarizado com Merleau-Ponty sabe o quanto, entre a Gestalt e a Fenomenologia, o campo aqui tratado é vasto. Porém, há alunos que tentam atravessar este autor pela via da faculdade lógica, gêmeos, o que leva a um resultado bastante diferente. Imagine o leitor as possibilidades de estudo e pesquisa abertas aqui.

Aquário é o pensamento corporal. Trata-se do corpo pensando. Qualquer evento que ocorra no âmbito corporal, além de produzir sensações, sentimentos, imagens, etc., também produz diversos níveis de informação: como uma totalidade, o corpo é um sistema de feedback no qual as informações, por meio de neurotransmissores, transitam de parte a parte, o que já levou alguns cientistas a afirmar que o cérebro é o próprio corpo. Na astrologia antiga, o signo do aquário regia as articulações e a circulação por causa desta analogia. Trata-se do que Edgar Morin chamou de pensamento complexo, outros de pensamento estrutural, outros de pensamento em rede. Por analogia também, podemos dizer que as experiências que envolvem uma "visão macro" são "aquarianas", isto é, aquelas que lidam com totalidades: planejamento urbano, diplomacia, internet.

Vale insistir que o espaço dado aqui ao zodíaco como mapa natal, isto é, como uma estrutura de abordagem psicológica de um indivíduo, é mínimo. Não apenas devido ao uso, a meu ver, equivocado da astrologia moderna, mas também pela complexidade da questão, que exige um vasto conjunto de pesquisas cuja metodologia resta ainda a ser estabelecida pois, com toda a evidência, os "métodos científicos" que pautam as intermináveis discussões em torno da validade da astrologia têm pouco ou nada a ver com a ciência encantada que nos interessa.

${ }^{255}$ Ver a respeito: Ibn 'Arabî, The Seven Days of the heart, op. cit. e Titus Burckhardt, Clé spirituelle, op. cit. 


\subsection{ESTRUTURALIDADES DESENCANTADAS: META- PROGRAMAS E 6 CHAPÉUS}

Com as considerações que farei a seguir, o caminho teórico percorrido na Parte 2 deste trabalho tomará outros rumos. A ambiance psicanalítica e filosófica será preterida e o novo cenário será composto agora de formulações extraídas em grande parte de abordagens da chamada psicologia cognitivista. A justificativa fundamental para tal procedimento reside na busca de uma espécie de "aproveitamento encantado" dos mais variados materiais que se encontram atualmente postos à disposição dos educadores. Trata-se, em última análise, de criticar tanto quanto de incluir o que for possível.

Preparo o leitor para esta mudança: sairemos de conversas com elfos da floresta diretamente para um apartamento em Nova York. De resto, nada há de espantoso nisso: se nossa inspiração primeira é o sufismo, devemos estar conscientes de que, com toda a evidência, é mais provável encontrar um sufi tomando cerveja num bar enfumaçado de Dublin, dirigindo um taxi no Rio de Janeiro ou expondo um trabalho sobre formigas numa universidade em Seattle que numa mesquita ou numa sinagoga entre homens barbados e sérios.

Definição de meta-programa: orientações que regem as ações. Os meta-programas podem ser comparados aos programas de computador: eles possuem a estrutura que está "por trás" das nossas ações no computador. Assim, a maneira com que produzimos um trabalho no word é diferente daquela com que produzimos o mesmo trabalho no power point. Se, por exemplo, você está focalizando um assunto, é diferente se você o focaliza panoramicamente, em grandes linhas (meta-programa de "grandes segmentos"), ou se você o focaliza em detalhe (pequenos segmentos). Veja dois relatos do mesmo assunto, um utilizando o meta-programa de grandes segmentos, o outro, de pequenos segmentos.

"Este jardim é lindo. Sua estrutura e composição são extremamente harmoniosos. A escolha das flores, combinadas às árvores, forma um todo agradável de se ver e convida- 
tivo ao relaxamento e ao bem-estar."

"Este jardim é lindo. Veja aquela mistura de rosas com lírios, que boa idéia! E as laranjeiras, combinando com as cores das flores do campo, dá vontade da gente ficar ali, junto."

Como é fácil notar, o meta-programa de grandes segmentos envolve uma orientação para ver o todo, o geral, o amplo. Já o de pequenos segmentos, busca o detalhe, os elementos, as partes.

Como se vê, não há um meta-programa mais certo ou melhor que outro, ao contrário, todos são úteis dependendo da situação e do propósito de cada um.

\subsubsection{EXEMPLOS DE META-PROGRAMAS}

Imagine 2 pessoas trabalhando juntas num projeto. Num certo momento, a pessoa "A" está elaborando um cenário do mercado (meta-programa de visão) e está construindo (meta-programa de futuro) uma idéia inovadora. A pessoa "B" escuta essa idéia utilizando, para isso, um meta-programa de passado em que o seu conhecimento e a sua experiência Ihe aparecem baseados em situações vividas de fato na empresa. Além disso, ela também faz a sua escuta a partir de um meta-programa de lógica, procurando, com isso, avaliar se a idéia lhe parece adequada. Tudo o que a pessoa "A" diz num registro (visão, futuro) é escutado pela pessoa "B" num outro registro (passado, lógica).

Podemos supor que o resultado da reunião entre essas 2 pessoas tem grande chances de resultar em desentendimento. Por estarem em registros diferentes, as pessoas tendem a ter dificuldade em compreender o que de fato está sendo dito. Na maior parte das vezes, elas assumem que o modo como estão entendendo corresponde exatamente ao que está sendo dito e, com isso, parte essencial da comunicação se perde.

Examinemos agora outro conjunto de meta-programas: o da hierarquia de critérios. Uma pessoa se sente mais confortável utilizando o meta-programa que foi batizado como "realização". Trata-se da orientação para a tarefa e o seu resultado. Uma outra pessoa pode sentir-se mais identificada com um outro meta-programa chamado "afiliação", ou seja, a sua orientação, numa situação qualquer, não é tanto o resultado mas é, sobretudo, as relações entre as pessoas envolvidas. Imaginem agora um diálogo entre essas duas pessoas:

- Temos que fazer isso com excelência. (meta-programa de realização)

- Ok, mas quem vamos incluir na equipe? (meta-programa de afiliação)

- Isso não importa! Temos que ver antes o prazo e as condições. 
- Como não importa? Isso é essencial, é a equipe que dá o resultado.

- Absurdo! Temos que conseguir esse resultado logo usando quem estiver disponível.

- Prá quê a pressa? Vai sair mal feito.

Poderíamos prosseguir nisso até que se desencadeasse uma guerra ou até que alguém viesse com a velha frase: "eu sou o chefe, portanto, será como estou dizendo".

O que é importante notar aqui é que, como na maioria das vezes, as pessoas não estão $D E$ FATO discordando. Elas estão basicamente abordando a questão com métodos diferentes. Agora, não se pode negar que AMBOS os métodos são razoáveis e podem perfeitamente ser utilizados pois um NÃO CONTRADIZ O OUTRO. Imaginem se essas mesmas pessoas conhecessem os meta-programas e, depois de identificar qual meta-programa o outro está utilizando (o que é muito fácil depois de um pequeno treino) utilizasse uma técnica de comunicação como, por exemplo:

- Temos que fazer isso com excelência. (meta-programa de realização)

- Concordo plenamente. Como você pensa fazer isso? (meta-programa de realização)

- Temos que ver o prazo e as condições. (meta-programa de realização)

- Certo. Muito bem. Vou providenciar isso imediatamente. Qual será a equipe? (metaprograma de afiliação)

- Ainda não pensei. O que você acha? (meta-programa de afiliação)

Notem que o $2^{\circ}$. colaborador observou que o $1^{\circ}$. estava usando um meta-programa de realização, assim, ele mesmo se manteve na realização e foi colaborando com o outro, fazendo perguntas, concordando, de modo a cumprir até o fim o pensamento da realização. Só depois é que ele introduziu o "seu" pensamento de afiliação. Nesse caso, o $1^{\circ}$. aceitou bem porque o seu modo de funcionar já estava, por assim dizer, satisfeito.

Vejamos agora outros "jeitos de funcionar".

\subsubsection{OS 6 CHAPÉUS}

Esta é uma técnica, criada pelo pesquisador inglês Edward de Bono, para organizar e dar foco ao pensamento. Trata-se de distinguir 6 tipos de pensamento (ver quadro abaixo) e de utilizá-los conscientemente, conforme as necessidades da situação. 


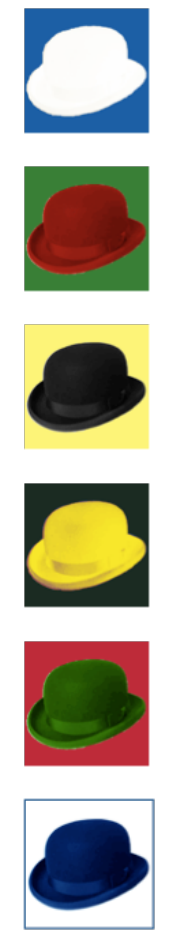

neutro, objetivo, não interpreta, não opina, relata fatos verificados e fatos

"acreditados" (dados e informações)

sentimentos, emoções; nunca são justificados

julgamentos complexos (palpites, impressões, gosto)

enunciados / julgamentos negativos / aponta o falso, o negativo, o que não é

adequado à experiência, perigos, riscos, falhas de um projeto, não é argumento, é

uma busca de colocar os elementos negativos de forma objetiva

enunciados positivos / construtivo, investiga e explora vantagens e valores / busca suporte lógico para valores e vantagens / criativo: faz propostas concretas / meta: eficiência, "fazer acontecer" / explora oportunidades, / possibilita sonhos e visões

recurso do pensamento criativo / além do óbvio e do satisfatório; "idéias malucas" / pausa para buscar alternativas / busca sair de uma idéia para chegar a outra nova / experimentos de pensamento, não se preocupa com acerto ou solução

maestro: pensamento sobre o pensamento / define qual dos outros 5 chapéus usar / define os problemas e delineia as soluções / organiza sequencias de operações do pensamento (coreografia)

Para entender como funciona essa técnica, vejamos, por exemplo, 2 tipos de pensamento: o pensamento das oportunidades (chapéu amarelo) e o dos possíveis riscos (chapéu preto).

Imaginemos uma reunião de gerentes responsáveis por um projeto. Um deles traz uma idéia utilizando o chapéu amarelo. Ele não sabe que o modo com que encara sua idéia foi batizado de "chapéu amarelo" por um pesquisador inglês. Ele não sabe que está traduzindo sua idéia segundo um certo jeito de traduzi-la e que haveria outros. Ele simplesmente crê que este é o jeito "certo" - honesto, franco, "pró-ativo" - de contá-la para seus colegas. Ele fala das oportunidades, de sua visão de como a idéia pode dar certo, ele está otimista.

Nesse momento, o seu colega ao lado "põe" o chapéu preto e começa a pensar quais os riscos e obstáculos possíveis, o que pode dar errado. O que vocês acham que acontece? Sob um certo ponto de vista, muita coisa. Sob outro, não acontece nada, porque a reunião não vai prá frente. Entre as muitas coisas que acontecem estão: os interlocutores não se entendem porque estão operando em registros diferentes. Cada um passa a "interpretar" o outro segundo o seu próprio registro. O "chapéu amarelo" acha que o colega não entendeu a idéia e, por isso, "está dizendo que ela é ruim" (notem, esta é uma interpretação, o seu colega não está dizendo isso, ele está fazendo aquilo que acha certo, de acordo com o registro que está utilizando no momento).

Então, com boa vontade, o "chapéu amarelo" começa a repetir a idéia, com o objetivo de que o outro a entenda finalmente. $\mathrm{O}$ "chapéu preto" fica impaciente ao ter que escutar de 
novo uma coisa que já entendeu perfeitamente e acha que o cara é prolixo (outra interpretação), o prolixo, quer dizer, o "chapéu amarelo", acha que o "chapéu preto" é um lesado, sem visão, uma típica toupeira (interpretação + jugamento rotulador).

Importante ressaltar o seguinte: se essas pessoas conhecessem a técnica dos 6 chapéus, poderiam facilmente identificar, no discurso do primeiro gerente, o amarelo. Rapidamente, todos na reunião passariam a usar o mesmo chapéu - que é um modo de pensar, tão bom e útil quanto qualquer outro. Em seguida, depois de esgotado esse jeito, todos passariam, por exemplo, a pensar nos riscos e obstáculos, e assim por diante até a questão ser pensada de 6 modos diferentes e, com isso, ser trabalhada em diversos níveis, garantindo, dessa forma, mais precisão, mais riqueza, mais abrangência, enfim, maior complexidade.

Obs.: Há consultorias que utilizam a técnica dos 6 Chapéus fazendo com que as pessoas busquem saber "qual é o seu chapéu", por mais absurdo e contraditório com a técnica que isso possa ser. Imaginem o estrago que pode causar a simples crença de que "fulano é um chapéu preto". A idéia vai justamente na direção contrária: o gerente que estava usando o chapéu amarelo não é um chapéu amarelo, ele pode perfeitamente usar qualquer outro "chapéu", basta que ele saiba disso. Você usa um chapéu assim como usa, por exemplo, um programa de computador. Ninguém diria: fulano é word, fulano é powerpoint!

Em síntese, a busca da sinergia reside, como foi dito, na busca do entendimento dos "jeitos de funcionar". Quanto mais conhecemos esses "jeitos", mais avançamos na arte de somar esforços e criar em conjunto. 


\subsection{O MODELO CALEIDOSCÓPIO - PRIMEIRA APROXIMAÇÃO}

Neste capítulo final da tese, optei por deixar registrado um esboço inicial da idéia de um modelo baseado nas considerações aqui realizadas. Na primeira concepção do projeto da tese, esse modelo seria construído por uma equipe multidisciplinar envolvida com os materiais teóricos e técnicos aqui articulados.

O Modelo Caleidoscópio é um modelo pedagógico de trabalho com a singularidade. Por esta razão, ele pode ser utilizado em qualquer contexto, por qualquer profissional, para qualquer tipo de público.

Ele comporta um conjunto de termos de referência formados a partir da articulação entre o pensamento contemporâneo e o Mundo Encantado (PARTES 1 e 2 do presente trabalho).

Comporta também um conjunto de dinâmicas e técnicas orientadas pelo pensamento analógico e sua utilização a partir dos termos de referência acima citados (IDEM).

Comporta, finalmente, um conjunto de dinâmicas e técnicas de trabalho com modelos mentais (PARTE 3).

Sua aplicação, mais comumente, consiste em:

- Formação de Educadores

- Criação de "espaços públicos" em escolas

- Grupos de Educação para adultos (ONGs, instituições, empresas, etc.)

O Modelo Caleidoscópio é, também, um modelo de pesquisa e investigação constantes. Ele parte de termos de referência do Encantamento e do pensamento contemporâneo para estruturar os mais diversos modos de investigar as situações e as pessoas nas situações. Utilizo a expressão "termos de referência" para evitar, numa primeira abordagem, 
palavras como "conceitos", "noções", cujo inconveniente, dado certo hábito do senso comum, seria estabelecer associações excessivamente mentais com o que aqui se expõe.

O texto abaixo, num tom propositalmente mais coloquial, pretende lançar uma base inicial da "pesquisa perene".

\subsubsection{O TERMO DE REFERÊNCIA DA PESQUISA E INVESTIGAÇÃO}

Quando você anda debaixo de um guarda-chuva, é como se você fosse recortando a chuva lá fora, de modo que, por onde quer que você vá, você vai levando o seu próprio espaço sem se molhar. Do mesmo modo, quando você está debaixo de um "termo de referência", você vai recortando a realidade e gerando um espaço particular dentro dela. Estar "debaixo" da referência da aventura significa que você entra nas situações de um jeito muito específico:

Em primeiro lugar, as experiências são oportunidades de "acertar o carro", como diria um piloto de Fórmula 1. Ou seja, você não fica parado, pensando, conjeturando, você vai para a pista correr e ver como o carro pode adaptar-se melhor àquelas condições. Assim, cada coisa que não vai bem não é sinal de que você é incompetente, estúpido ou coisa que o valha. É um sinal do que pode e deve ser melhorado. Uma falha não é considerada um fracasso mas sim um feedback. Por exemplo, um erro cometido - apesar das frustrações naturais que suscita - torna-se uma informação importante porque revela o que pode ser corrigido - e não o que "está errado" - evoca uma possibilidade no futuro, não uma perda definitivamente encerrada no passado. Isso permite um distanciamento e, ao mesmo tempo, uma entrega pessoal maior.

Em segundo lugar, você não entra nas experiências com uma idéia já formada do resultado, com a postura de que "isso tem que acontecer de qualquer maneira" ou "isso tem que dar certo", porque esta é uma postura muito forçada e com pouca utilidade prática. Ao contrário, você entra como quem está pesquisando, colhendo informações, descobrindo coisas, numa palavra, aprendendo.

Em terceiro lugar, você não fica se dizendo que uma experiência é um lugar de aplicar o que você já sabe para obter o melhor resultado possível, como se viver fosse estar sempre fazendo prova na escola. Claro, você sempre vai utilizar o que sabe, mas isto nunca vai dar conta da situação inteira, por mais que você se prepare. Se não fosse isso, não haveria evolução.

A idéia, na referência da Pesquisa, é que tudo depende de tempo, lugar e pessoas. Se uma dessas coordenadas mudar (e sempre mudam), a situação já é outra, inevitavelmente. Debaixo desse guarda-chuva, a idéia de rotina não existe, tudo é pesquisa, investigação. Quer dizer que você se torna um pesquisador permanente. 
Esse modo de focalizar o trabalho permite que você se mantenha tecnicamente aberto para a descoberta de novas potencialidades, isto é, aprende a desenvolver uma observação mais sofisticada de modo que, o que, antes, poderia passar desapercebido, agora, se houver condições, pode vir a ser um insight.

Desenvolver uma mentalidade de pesquisa significa compreender que os acontecimentos não são fatos, mas sim informações que nos indicam quão próximos ou distantes estamos de nossas metas e como podemos caminhar mais decididamente em direção a elas.

Significa, também, perceber que pesquisa não é uma etapa, uma coisa a mais dentro de um processo, mas é o próprio processo, é o foco, é um jeito de estar.

O objetivo principal do Modelo não é, portanto, formar pessoas mas, sim, constituir espaços públicos simbólicos nos quais se compartilhem mentalidades de indagação, investigação e pesquisa.

\section{QUADRO SÍNTESE DO MODELO}

\section{CRÍTICA DA IDEOLOGIA}

\section{CRÍTICA DO EGO}

1. autocrítica

2. autoobservação posições imaginárias

\section{CRIAÇÃO DE 1 ESPAÇO PÚBLICO:} numa escola, numa ONG, numa empresa, etc.

TRABALHO COM LINGUAGENS:

\section{PENSAMENTO ANALÓGICO}

arte + histórias de ensinamento

1. aprender a se relacionar

\section{MODELO CALEIDOSCÓPIO}

TIPOLOGIAS

relacionamento:

'adab

modelos mentais

astrologia com as coisas como se fossem linguagens $\rightarrow$ aprender a aprender

2. denarcisação / desapego /

trânsito por linguagens

3. traduções entre linguagens, uso das faculdades: razão, intuição, imaginação, etc.

4. construção de um espaço público simbólico

\section{ARTICULAÇÃO ENTRE AUTOCONHECIMENTO E CIDADANIA}


234 


\section{PARTE 4: ANEXOS}

Alguém reclamou com um sábio sufi que as histórias que ele contava eram interpretadas de uma maneira por uns e de outra por outros.

- É precisamente o que faz o seu valor, disse o sábio. Que caso faria você de um copo no qual se pudesse beber leite mas não água, de um prato no qual se pudesse comer carne mas não frutas? Copo e prato são recipientes limitados. A linguagem, não deveria ela ser infinitamente mais capaz de for-

necer alimento? A questão não é: "de quantas maneiras posso compreender isto e por que é que eu não posso vê-lo de uma única maneira?" A questão é antes: "tal indivíduo, poderia ele tirar proveito daquilo que encontra nas histórias?" 


\subsection{ANEXO 1 - SOBRE IBN 'ARABÎ}

Muhyyddîn Abû Abdallalâh Muhammad Ibn 'Ali Ibn 'Arabî al-Hâtimî al-Tâ'i (1165 / 1240), também chamado de Shay $\underline{\underline{h}}$ al-Akbar ${ }^{256}$ ("o maior dos Mestres" ou "o Mestre por exce(ência"), nasceu em Murcia, na Espanha moura, isto é, no período que ficou conhecido como al-Andalus - a época em que boa parte da Península Ibérica esteve sob domínio muçulmano.

Embora sua obra monumental tenha, por diversas vias, influenciado autores tanto no Oriente quanto no Ocidente, seu nome permaneceu desconhecido entre os pensadores modernos até o início de nosso século, quando o padre arabista espanhol Miguel Asin Palacios desenvolveu sua polêmica tese a respeito da influência de Ibn 'Arabî sobre nada mais nada menos que Dante Alighieri em sua Divina Comédia.

Em sua pesquisa, Asin Palacios recupera a época fervilhante em que judeus, cristãos e muçulmanos conviviam harmoniosamente; em que - pelo vigor intelectual resultante da renovação trazida pela última Revelação da história - surgiram as primeiras universidades na Europa; em que as ciências do Trivium e do Quadrivium encontraram seu apogeu; em que a filosofia e as artes floresceram de Córdoba a Bagdá; em que os muçulmanos, em vez de arrebatar o botim de suas conquistas, exigiam dos vencidos que lhes entregassem os manuscritos que possuíssem a fim de traduzi-los para o árabe - graças ao quê inúmeros clássicos puderam chegar até nós.

É precisamente no final deste período de 5 séculos (do início da expansão do Islam no séc. VIII até o séc. XIII, com o início da decadência da Espanha moura) que o Shay $\underline{\underline{h}}$ al-Akbar irá compor sua summa mystica, como a condensar todo o conhecimento de uma época que, como se sabe, foi durante muito tempo designada como Idade das Trevas e, somente a partir da segunda metade do século XX, pôde ser melhor investigada e, portanto, redescoberta como um dos momentos mais férteis da história da humanidade.

Por sua bibliografia muito recentemente estabelecidaa ${ }^{257}$, sabe-se hoje que a obra do mestre andaluz compreende em torno de 150 títulos. Entre estes, alguns são pequenas obras, outros correspondem a textos que se estendem por centenas de páginas e outros ainda por milhares de páginas, como sua obra máxima, al-Futûhât al-Makkiyya (as lluminações da Meca), possuindo 36 volumes e 560 capítulos. Embora uma parte importante tenha se perdido - por exemplo, um comentário inacabado do Corão de 64 volumes - a maior parte da obra foi preservada ao longo desses sete séculos.

\footnotetext{
${ }^{256}$ Pronuncia-se "chaih", sendo que este último "h" é aproximadamente como o som da letra "j" no espanhol.

${ }^{257}$ Ver Yahia, O., Histoire et Classification de l'oeuvre d'Ibn 'Arabî.
} 
Como não poderia deixar de ser em se tratando de Mística, Ibn 'Arabî também foi alvo de encarniçada perseguição. Os "doutores da lei", juristas islâmicos (fuqahâ) que consideraram inúmeras afirmações do Shay $\underline{\underline{h}}$ como heresias ou como bida', termo técnico da jurisprudência islâmica que designa as "inovações" ou "desvios da ortodoxia", promoveram ataques verbais, difamações, polêmicas ${ }^{258}$. Recentemente, no Egito, a edição dos Futûhât Makkiyya foi retardada em alguns anos devido à proibição de sua publicação (mais tarde revogada) pelo parlamento egípcio.

Comentando as dificuldades de se encontrar, entre os mais diversos autores, uma compreensão mais acurada da obra akbari ${ }^{259}$, um dos principais especialistas modernos no estudo de Ibn 'Arabî, Michel Chodkiewicz, Directeur d'Études na École des Hautes Études en Sciences Sociales, em Paris, observa que:

"A combinação, na pessoa de Ibn 'Arabî, da santidade e do gênio, a fusão em sua obra das mais diversas ciências e formas literárias tornam, é verdade, muito difícil explicar - e, antes de tudo, captar - sua natureza e sua estatura." 260

"A complexidade de uma doutrina que abarca, numa vertiginosa síntese, todos os domínios das ciências tradicionais, da jurisprudência à metafísica; as formulações sobre elas dadas pelo Shay $\underline{\underline{h}}$ al-Akbar, com frequência paradoxais ou enigmáticas; a imensidão enfim de uma obra que conta com dezenas de milhares de páginas parecem próprias a desencorajar a difusão do ensinamento akbariano." 261

Seria de se esperar que uma obra tão vasta quanto complexa e hermética ficasse restrita a um grupo seleto de "especialistas". A história demonstra o contrário.

"Numerosos estudiosos sublinharam a extensão no espaço geográfico do Maghreb ao Extremo Oriente - da influência de Ibn 'Arabî. Mas é ainda mais importante medir e compreender a profundidade desta influência: a marca do ensinamento akbariano não foi impressa apenas no sufismo "intelectual". Ela pode também ser detectada no universo das confrarias que embaralha as classes sociais e os níveis culturais mais diversos." 262

\footnotetext{
${ }^{258}$ Cf. em duas obras de Chodkiewicz, M., Le Sceau des Saints, Introdução e Un Océan Sans Rivage, também Introdução. Para uma biografia completa de Ibn 'Arabî, ver Claude Addas, La quête du soufre rouge.

259 Este termo significa, no árabe, conforme utilização consagrada por seus discípulos, "do Shayh al-Akbar", isto é, Ibn 'Arabî. Nós o escrevemos sem itálico para propor utilizá-lo deste modo em português, seguindo o modelo dos tradutores espahóis, de preferência a "akbariano", termo utilizado pela maioria dos tradutores franceses.

${ }^{260}$ Chodkiewicz, Le Sceau, p. 15.

${ }^{261}$ Idem, Océan, p. 18.

${ }^{262}$ Idem, ibidem.
} 


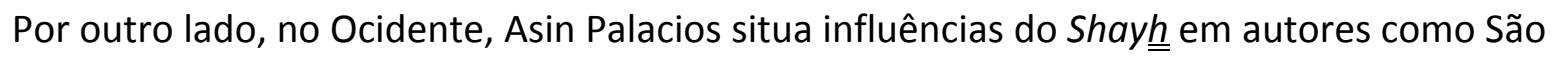
Boaventura, Guillermo de Auvernia, Alejandro de Hales, Duns Escoto, Roger Bacon e Raimundo Llulio, entre outros ${ }^{263}$.

Como um Mestre - termo cujo sentido original escapa ao "ocidental atual" - Ibn 'Arabî escreveu não para pensadores mas para "viajantes", isto é, para os seguidores da via mística. Sua obra não pode ser compreendida como um conjunto de idéias, mas como um guia.

"Pois esta obra, diferentemente de todas que a precederam, apresenta uma característica (...): ela possui resposta para tudo. De omni re scibili: ontologia, cosmologia, profetologia, exegese, ritual, angeologia..., ela abarca em sua totalidade as ciências das quais os "homens da Via" não poderiam privar-se sem perigo." ${ }^{264}$

${ }^{263}$ Asín Palacios, M., La Escatologia Musulmana en la Divina Comédia, p. 399.

${ }^{264}$ Chodkiewicz, Océan, p. 36. 


\subsection{ANEXO 2 - HISTÓRIAS}

\section{NASRUDIN}

1

Mulla Nasrudin caminhava, certo dia, por uma rua estreita quando um homem despencou de um telhado e foi cair em cima dele. O homem não se machucou mas o mulla foi levado para o hospital.

- Que ensinamento inferes desse sucedido, mestre? - perguntou-Ihe um discípulo.

- Não acredite na inevitabilidade, ainda que causa e efeito pareçam inevitáveis! Fuja de perguntas teóricas como: "Se um homem despencar de um telhado, quebrará o pescoço?" Ele caiu, mas foi o meu pescoço que se quebrou!

\section{2}

Montado em seu burro, Nasrudin costumava cruzar, todos os dias, uma fronteira levando cestos cheios de palha. Como ele se confessava contrabandista, os guardas da fronteira revistavam-no todos os dias quando o viam voltando para casa. Revistavam-no, examinavam com extremo cuidado a palha, mergulhavam-na dentro d'água e chegavam até a queimá-la. Entrementes, ele prosperava visivelmente.

Depois disso, ele se aposentou e foi viver em outro país, onde, anos mais tarde, um dos funcionários da alfândega topou com ele.

- Agora você pode me contar, Nasrudin - disse o funcionário. - O que era que você contrabandeava naquele tempo em que nunca conseguimos apanhá-lo?

- Burros - respondeu Nasrudin.

\section{3}

Um dia, Nasrudin estava sentado na corte. Queixava-se o rei de que seus súditos eram mentirosos.

- Majestade - disse Nasrudin -, há verdade e verdade. As pessoas precisam praticar a verdade real antes de poderem usar a verdade relativa, mas sempre tentam inverter o processo. Resultado: sempre tomam liberdades com a sua verdade humana, porque sabem, por instinto, que se trata apenas de uma invenção.

O rei achou a explicação complicada demais.

- Uma coisa tem de ser verdadeira ou falsa. Farei as pessoas dizerem a verdade e, com essa prática, elas adquirirão o hábito de serem verazes.

Quando se abriram as portas da cidade, na manhã seguinte, uma forca se erguia diante delas, controlada pelo capitão da guarda real. Um arauto anunciou:

- Quem quiser entrar na cidade terá de responder com verdade à pergunta que lhe será formulada pelo capitão da guarda.

Nasrudin, que estava esperando do lado de fora, foi o primeiro a dar um passo à frente. O capitão dirigiu-se a ele:

- Aonde vai você? Diga a verdade; a alternativa é a morte por enforcamento.

- Vou - respondeu Nasrudin - ser enforcado naquela forca. 
- Não acredito em você!

- Pois, muito bem. Se eu disse uma mentira, enforque-me!

- Mas isso faria dela a verdade!

- Exatamente - confirmou Nasrudin -, a sua verdade.

\section{4}

Um rei, que gostava da companhia de Nasrudin e também gostava de caçar, ordenou-lhe que o acompanhasse numa caçada de ursos. Nasrudin ficou aterrorizado.

Quando voltou à sua aldeia, alguém Ihe perguntou:

- Como foi a caçada?

- Maravilhosamente.

- Quantos ursos você viu?

- Nenhum.

- Mas, então, como pode ter ido maravilhosamente?

- Quando você está caçando ursos e quando você sou eu, não ver urso nenhum é uma experiência maravilhosa.

\section{5}

Saído de alguma das profundezas do país, um parente veio visitar o mulla e trouxe-lhe um pato de presente. Encantado, Nasrudin mandou cozinhar a ave e partilhou-a com o hóspede. Depois disso, entretanto, um conterrâneo depois do outro começou a visitá-lo, cada um deles dizendo ser amigo do amigo do "homem que lhe trouxe o pato". Mas nenhum outro presente lhe foi oferecido.

Finalmente, o mulla exasperou-se. E, um dia, outro estranho apareceu.

- Sou amigo do amigo do amigo do parente que lhe trouxe o pato.

E sentou-se como todos os outros, esperando uma refeição. Nasrudin estendeu-lhe uma tigela de água quente.

$-\mathrm{O}$ que é isso?

- É a sopa da sopa da sopa do pato que me foi trazido pelo meu parente.

\section{6}

Nasrudin bateu à porta de um casarão pedindo esmola. Disse-lhe o criado:

- Meu amo não está.

- Muito bem - volveu o mulla - ainda que ele não tenha sido capaz de contribuir, dê por favor ao seu amo um conselho meu. Diga a ele: "Da próxima vez que o senhor sair, não deixe o rosto na janela - alguém poderá roubá-lo".

\section{7}

Numa ocasião, um vizinho encontrou Nasrudin de joelhos, no quintal, procurando alguma coisa.

- O que foi que você perdeu, mulla?

- Minha chave - respondeu Nasrudin.

Depois de alguns minutos de busca, o outro homem perguntou:

- Onde foi que a deixou cair? 
- Em casa.

- Então por que, santo Deus, a está procurando aqui?

- Porque aqui fora tem mais luz.

Histórias de Nasrudin extraídas do livro "Los Sufies", de Idries Shah, obra citada. 


\section{FÁTIMA, A FIANDEIRA}

Numa cidade do mais longínquo Ocidente vivia uma jovem chamada Fátima, filha de um próspero fiandeiro. Um dia, o pai lhe disse:

- Filha, faremos uma viagem, pois tenho negócios a resolver nas ilhas do Mediterrâneo. Talvez você encontre por lá um jovem atraente, de boa posição, com quem possa então se casar.

Iniciaram assim sua viagem, indo de ilha em ilha; o pai cuidando de seus negócios, Fátima sonhando com o homem que poderia vir a ser seu marido. Mas um dia, quando se dirigiam a Creta, armou-se uma tempestade e o barco naufragou. Fátima, semiconsciente, foi arrastada pelas ondas até uma praia perto de Alexandria. Seu pai estava morto e ela ficou inteiramente desamparada.

Podia recordar-se apenas vagamente de sua vida até aquele momento, pois a experiência do naufrágio e o fato de ter ficado exposta às inclemências do mar a tinham deixado completamente exausta e aturdida.

Enquanto vagava pela praia, uma família de tecelões a encontrou. Embora fossem pobres, levaram-na para sua humilde casa e ensinaram-Ihe seu ofício. Desse modo, Fátima iniciou nova vida e, em um ou dois anos, voltou a ser feliz, reconciliada com sua sorte. Porém um dia, quando estava na praia, um bando de mercadores de escravos desembarcou e levoua junto com outros cativos.

Apesar dela se lamentar amargamente de seu destino, eles não demonstraram nenhuma compaixão: levaram-na para Istambul e venderam-na como escrava. Pela segunda vez o mundo da jovem ruíra.

Mas, quis a sorte que no mercado houvesse poucos compradores na ocasião. Um deles era um homem que procurava escravos para trabalhar em sua serraria, onde fabricava mastros para embarcações. Ao perceber o ar desolado e o abatimento de Fátima, decidiu comprá-la, pensando que poderia proporcionar-lhe uma vida um pouco melhor do que teria nas mãos de outro comprador.

Ele levou Fátima para casa com a intenção de fazer dela uma criada para sua esposa. Mas ao chegar em casa soube que tinha perdido todo o seu dinheiro quando um carregamento fora capturado por piratas. Não poderia enfrentar as despesas que the davam os empregados, e assim ele, Fátima e sua mulher arcaram sozinhos com a pesada tarefa de fabricar mastros.

Fátima, grata ao seu patrão por tê-la resgatado, trabalhou tanto e tão bem que ele lhe deu a liberdade, e ela passou a ser sua ajudante de confiança. Assim, ela chegou a ser relativamente feliz em sua terceira profissão.

Um dia, ele Ihe disse:

- Fátima, quero que vá a Java, como minha representante, com um carregamento de mastros; procure vendê-los com lucro.

Ela então partiu. Mas, quando o barco estava na altura da costa chinesa, um tufão o fez naufragar. Mais uma vez Fátima se viu jogada como náufraga em uma praia de um país desconhecido. De novo chorou amargamente, porque sentia que nada em sua vida acontecia como esperava. Sempre que tudo parecia andar bem alguma coisa acontecia e destruía suas esperanças. 
- Por que será - perguntou pela terceira vez - que sempre que tento fazer alguma coisa não dá certo? Por que devo passar por tantas desgraças?

Como não obteve respostas, levantou-se da areia e afastou-se da praia.

Acontece que na China ninguém tinha ouvido falar de Fátima ou de seus problemas. Mas existia a lenda de que um dia chegaria certa mulher estrangeira capaz de fazer uma tenda para o imperador. Como naquela época não existia ninguém na China que soubesse fazer tendas, todo mundo aguardava com ansiedade o cumprimento da profecia.

Para ter certeza de que a estrangeira ao chegar não passaria despercebida, uma vez por ano os sucessivos imperadores da China costumavam mandar seus mensageiros a todas as cidades e aldeias do país pedindo que toda mulher estrangeira fosse levada à corte.

Exatamente numa dessas ocasiões, esgotada, Fátima chegou a uma cidade costeira da China. Os habitantes do lugar falaram com ela através de um intérprete e explicaram-Ihe que devia ir à presença do imperador.

- Senhora - disse o imperador quando Fátima foi levada até ele - sabe fabricar uma tenda?

- Acho que sim, Majestade - respondeu a jovem.

Pediu cordas, mas não tinham. Lembrando-se dos seus tempos de fiandeira, Fátima coIheu linho e fez as cordas. Depois pediu um tecido resistente, mas os chineses não o tinham do tipo que ela precisava. Então, utilizando sua experiência com os tecelões de Alexandria, fabricou um tecido forte, próprio para tendas. Percebeu que precisava de estacas para a tenda, mas não existiam no país. Lembrando-se do que lhe ensinara o fabricante de mastros em Istambul, Fátima fabricou umas estacas firmes. Quando estas estavam prontas ela puxou de novo pela memória, procurando lembrar-se de todas as tendas que tinha visto em suas viagens. E uma tenda foi construída.

Quando a maravilha foi mostrada ao imperador da China ele se prontificou a satisfazer qualquer desejo que Fátima expressasse. Ela escolheu morar na China, onde se casou com um belo príncipe, e, rodeada por seus filhos, viveu muito feliz até o fim de seus dias.

Por meio dessas aventuras Fátima compreendeu que o que em cada ocasião Ihe tinha parecido ser uma experiência desagradável acabou sendo parte essencial de sua felicidade.

Acessado do site: "Instituto Outra História" 


\section{O PRÍNCIPE ADIL E OS LEÕES}

Há muito tempo atrás e muito longe daqui, vivia um rei que tinha um filho de quem ele gostava muito e que se parecia muito com ele quando era jovem.

Um dia, o rei Azad disse ao grão vizir:

- Vamos levar meu filho à cova do leão e dizer-lhe o que se espera dele, agora que completou 18 anos.

O príncipe Adil foi chamado à presença do rei e o grão vizir assim lhe disse:

- Alteza, sempre foi costume nesta nobre família, quando o herdeiro do trono chega à idade que você tem agora, que ele passe por um certo teste. Isto é para que fique estabelecido, sem nenhuma dúvida, se o príncipe está apto ou não para ser o futuro governante do nosso povo. Venha conosco e nós lhe mostraremos o lugar onde será seu teste.

O príncipe seguiu seu pai e o grão vizir até uma grande porta na parede de uma cova rochosa. Havia uma pequena grade na porta, através da qual podia-se ouvir o rugido de um leão.

- Veja, meu filho, disse o rei alisando a barba, aí dentro está um enorme leão criado na floresta. Você deve lutar com ele e submetê-lo com uma adaga e uma espada. Você pode fazer isso quando quiser. Todo homem de nossa família teve que passar por este teste antes de herdar o trono.

O príncipe olhou pela grade e empalideceu, pois o que ele viu foi de fato um leão muito grande, andando de um lado para o outro de uma caverna cheia de ossos. O animal tinha uma juba espessa e dentes brancos e afiados. De vez em quando, ele franzia o nariz, arreganhava os dentes e dava um rugido horripilante.

- Lutar? Submeter? Matar esta coisa? Como poderei fazer isso? O máximo que consegui até hoje foi matar um veado ou mandar meu falcão caçar um pássaro. Eu tenho certeza de que um leão deste tamanho e com toda esta força está além das minhas possibilidades, dizia o príncipe quase sem voz.

- Não tenha medo, disse o grão vizir. Você não precisa fazer isso agora. Um dia você poderá fazê-lo, quando se acostumar com a idéia. Pela graça de Allah, você vai encontrar a confiança necessária, quando tiver pensado um pouco sobre o assunto. Todos os seus antecessores o fizeram no final.

O rei sorriu e fez um sinal para que um escravo jogasse um pouco de carne para o leão, que a devorou com satisfação.

Depois disso, os dias se passaram e, embora o rei continuasse tratando seu filho tão gentilmente quanto antes, Adil sentia que sua tarefa pesava sobre ele e que seu pai devia estar ansioso para que matasse o leão imediatamente. Ele não conseguia sentir prazer em nada, pensando no que tinha que fazer.

Uma noite, depois de virar-se e revirar-se na cama sem conseguir dormir, ele se levantou. Vestiu-se, encheu uma bolsa com muitas moedas de ouro e foi até os estábulos reais. Acordou seu escudeiro e pediu-lhe que selasse seu cavalo favorito e que dissesse ao rei que ele ia fazer uma viagem.

A lua brilhava no céu e o príncipe se foi, sem olhar para trás, buscando uma resposta para seu problema. 
Na manhã seguinte, chegou à beira de um rio com prados verdejantes dos dois lados. Enquanto o cavalo bebia água, ele ouviu o som de uma flauta e logo em seguida avistou um jovem pastor levando carneiros para o pasto. Adil perguntou-lhe se ali por perto havia algum lugar onde ele pudesse ficar por uns dias. O pastor levou-o ao seu patrão, um homem rico que morava numa casa muito grande nas redondezas. Lá, o homem, que se chamava Haroun, convidou Adil para jantar e perguntou-lhe:

- De onde você vem e como estão seus rebanhos?

O príncipe respondeu com evasivas, dizendo que tivera certos problemas em casa que o obrigaram a viajar. Disse também que estava buscando uma resposta para uma questão pessoal, pedindo ao velho homem que não lhe perguntasse mais nada.

Imediatamente Haroun disse que Adil poderia ficar em sua casa quanto tempo quisesse e que ali ficassse à vontade. Seu cavalo foi levado ao estábulo e o príncipe pensou que gostaria de ficar um longo tempo naquele espaço tão tranquilo.

A cada dia descobria um lugar encantador onde se podia ouvir o som das flautas dos pastores, que naquela área eram inúmeros, pois aquela era a Terra dos Tocadores de Flauta Celestiais.

Acontece que uma noite, horrorizado, o príncipe ouviu rugidos de leões não longe da casa e contou a Haroun na manhã seguinte.

- Ah, sim, respondeu ele calmamente. Este lugar está infestado de leões. Eles caçam à noite. Fico surpreso de que você ainda não os tenha escutado. Por isso temos este alto muro em volta do jardim, senão eles já teriam levado toda a minha família. - E ele ria com gosto, como se tivesse dito uma piada.

O coração do príncipe encheu-se de medo. Assim que preparou seu cavalo para partir, despediu-se de Haroun agradecendo sua hospitalidade e, mais uma vez, pos-se na estrada, cavalgando o mais rápido que podia. À medida em que viajava, foi deixando para trás os verdes vales enquanto ia surgindo a sua frente uma árida planície arenosa onde não se via um único tufo de grama. O cavalo avançava com dificuldade, enfrentando o vento que, de vez em quando, levantava nuvens de poeira seca. Adil sabia que precisava logo encontrar água para ambos. Em silêncio, rezou para que na próxima duna surgisse um acampamento de beduínos ou um oásis pequeno.

Como em resposta a sua oração, ele viu no horizonte uma fila de tendas negras. Vários guerreiros se aproximaram, suas armas reluzindo ao sol, e o saudaram gritando "Assalamu Aleikum!". Eles o escoltaram até o Sheikh, que o recebeu calorosamente, dizendo-lhe que tinha muita honra em tê-lo como hóspede e que ele poderia ficar quanto tempo desejasse. Depois de uma deliciosa refeição de carneiro cozido, arroz com especiarias, figos e tâmaras maravilhosamente doces, o Sheikh perguntou a Adil que ventos o levavam naquela direção.

- Não me pergunte mais nada, disse o príncipe. Basta que você saiba que deixei minha casa com um problema, que espero resolver, tendo me ausentado da casa de meu pai até me sentir mais seguro de minha situação.

O Shay $\underline{\underline{h}}$ inclinou a cabeça, alisou a barba e deu uma baforada no cachimbo.

- O tempo nos dá todas as respostas, murmurou, se pudermos ser pacientes.

O príncipe sentiu que poderia ficar para sempre naquele lugar, onde, durante o dia, respirava o ar frio e fresco do deserto, caçando antílopes e comendo fartas comidas na compa- 
nhia do Shay $\underline{\underline{h}}$.

Mas um dia, depois de duas semanas de tranquilidade, o velho Shay $\underline{\underline{h}}$ the disse:

- Meu filho, meu povo e eu gostamos de você e admiramos o modo como se juntou a nós em nossos divertimentos. Mas somos guerreiros e temos que lutar com outras tribos. É necessário ter muita bravura pessoal para a nossa sobrevivência, por isso, gostaríamos de submetê-lo a um teste onde pudéssemos ter uma evidência do seu valor. A duas milhas ao sul desta área está uma cadeia de montanhas infestada de leões. Levante-se cedo amanhã e, depois da oração do alvorecer, pegue o melhor de nossos cavalos e com uma lança e uma espada mate um destes animais. Depois disso, arranque sua pele e traga-a para nós, assim terá provado sua valentia.

O rosto do príncipe tornou-se branco como cera e enquanto dizia boa noite ao Shayh, tomado pelo medo, tinha certeza de que não poderia enfrentar aquelas criaturas selvagens.

- Deus do céu, dizia-se ao abandonar o acampamento antes da última refeição da noite, parece que encontro leões em qualquer lugar para onde vou. Não possso entender, afinal, eu saí de casa justamente para evitá-los.

Viajou muito tempo pela noite estrelada. De manhã chegou a uma bela região onde as flores selvagens cresciam nas montanhas. Avistou ao longe um magnífico palácio, o mais belo que ele jamais vira. Era feito de uma pedra rosada, com colunas de lápis lazuli e balcões de madeira esculpida e pintada de várias cores. Havia fontes nos jardins a sua volta, pássaros que cantavam em árvores cheias de flores, e muitos pavilhões cobertos de jasmins e rosas docemente perfumadas.

- Parece um paraíso na terra! disse Adil para si mesmo enquanto se aproximava do palácio. Nos portões, guardas levaram-no ao quarto de hóspedes, onde tomou um banho e vestiu roupas limpas, ajudado por servos sorridentes. Depois, foi conduzido à presença do Emir, um homem de barbas cinzentas que lhe perguntou o que o trouxera ali. Junto dele estava sua filha Peri-zade, que tinha lindos olhos amendoados e um cabelo negro como a cauda de um pássaro.

- Minha situação é tal que não posso falar dela, tentou responder o príncipe, evitando oIhar para a adorável Peri-zade, por quem ele tinha imediatamente se apaixonado. - Eu deixei meu país porque tinha um problema para resolver.

- Eu entendo, disse o Emir balançando a cabeça. E começou a falar de outros assuntos.

Depois da refeição, o Emir mostrou a Adil o palácio por dentro em toda sua magnificência. Escadas de mármore levavam a aposentos cheios de móveis de madeira de várias partes do mundo. As paredes e o teto eram cobertos de mosaicos de turquesa e ouro, afrescos e espelhos. As janelas eram de vidro transparente pintado em cores delicadas e os tapetes macios como seda, tão bem tecidos e mostrando paisagens tão harmoniosas que quase não pareciam ter sido feitos por mãos humanas.

O Emir o levou finalmente a seu quarto para que ele pudesse descansar e lhe disse que ele ficasse ali o quanto lhe fosse possível ficar.

Sozinho, olhando todo aquele esplendor a sua volta, Adil pensou que naquele lugar ele poderia ficar o resto de sua vida.

Muitos dias se passaram. A princesa Peri-zade encantava-se em poder mostrar ao príncipe os jardins em várias horas diferentes. Um dia, ao entardecer, ele a ouvia cantar e tocar alaúde com extrema graça e perfeição. Foi então que escutou um som que o arrepiou dos 
pés à cabeça.

- Pare, gritou ele, que som foi este?

- Não ouvi nada, ela respondeu um pouco aborrecida pela interrupção. e continuou a tocar.

- Foi ali, perto de uns arbustos. Parecia o rugido de um leão!

Ela riu e lhe disse:

- É apenas Rustum, nosso guardião, como o chamamos. É o animal de estimação de toda a corte. A esta hora ele vigia nossos jardins. Eu o conheço desde que era um filhotinho e à noite ele dorme à porta do meu quarto.

Nesta noite, completamente cheio de medo, o príncipe quase não tocou na comida. Quando subiu as escadas acompanhado pelo Emir, quase saiu correndo ao ver o enorme leão parado à porta do seu quarto.

- Veja que honra, disse o Emir. O bom Rustum está esperando para levá-lo para a cama! Ele não faz isso com muita gente, não. Apenas se aborrece se vê que alguém tem medo dele. Mas, na realidade, é extremamente manso.

- Eu tenho medo dele, sussurrou o príncipe, realmente tenho muito medo.

Mas o Emir pareceu não escutá-lo e se despediu, deixando Adil com o leão. O príncipe abriu a porta e, o mais rápido que pôde, fechou-a atrás de si. Não conseguiu dormir a noite inteira. Quando se levantou pela manhã, começou a pensar que seria melhor voltar para casa. Havia tantos leões no seu caminho que seria melhor lutar com o leão na cova e acabar logo com isso, em vez de ficar fugindo a vida toda. Foi até o Emir e lhe disse:

- Peço permissão para partir e enfrentar meu próprio problema a minha maneira, ou então nunca estarei em paz comigo mesmo. Sou um covarde e quero deixar de sê-lo, em honra de meu pai. Sou o filho do rei Azad e fugi do dever que todos os homens de minha família devem realizar. Estou envergonhado e sei que nunca poderei pedir a mão da princesa Perizade enquanto não encarar meu destino e lutar com o leão naquela cova.

- Muito bem falado, meu filho, disse o Emir. Desde o primeiro momento eu soube quem você era, pois você se parece muito com seu pai quando jovem. Sempre respeitei e admirei o rei Azad. Vá, lute com o leão e eu Ihe darei minha filha em casamento.

O príncipe montou no seu cavalo e galopou até o acampamento das tendas pretas.

- Benvindo, príncipe Adil, disse o Shayh beduíno, conheci o seu pai quando tínhamos ambos a idade que você tem agora. Eu pude saber quem você era pela enorme semelhança que você tem com ele, aliás, maior agora de que no dia em que você chegou aqui.

Adil contou-Ihe sobre sua intenção de voltar para casa, o que muito agradou ao Shayh.

Depois de descansar aquela noite, o príncipe seguiu viagem e descobriu, no caminho, que estava com muita saudade de casa, com leão e tudo e que mal podia esperar para dizer a seu pai que estava preparado para enfrentar aquela criatura dentro da cova.

Logo chegou à terra dos tocadores de flauta celestiais. Quando encontrou o dono daqueles campos no pátio de sua casa, ele lhe disse:

- Quando cheguei aqui pela primeira vez, era um covarde. Agora estou pronto para lutar e fazer o que meus antepassados fizeram, seja qual for o resultado. Tenho confiança em Allah, o compassivo.

- Que assim seja, disse o velho homem. Eu sabia que você - sendo o verdadeiro filho de seu pai, que foi meu companheiro quando estudamos juntos - no tempo certo, iria enfren- 
tar suas dificuldades. Vá e que Allah esteja com você!

Algum tempo depois, Adil chegou a seu reino e pediu imediatamente ao grão-vizir para levá-lo à cova do leão. O velho rei o abraçou muito feliz e os tres se dirigiram para a caverna.

A espada e a adaga que o príncipe carregava brilhavam ao sol. Então, um escravo abriu a enorme porta e Adil entrou corajosamente.

O leão começou a rugir, levantou-se e andou na direção do príncipe com a enorme mandíbula aberta. O príncipe olhou para aquele animal sem medo, armas na mão, enquanto o rei, o vizir e o escravo ficaram em silêncio, observando. O leão deu um outro rugido, mais forte que o anterior e chegou perto dele. Então, para o espanto do príncipe, o monstro pôs-se a esfregar sua cabeça contra seus joelhos e lambeu suas botas como um cão amestrado.

- Agora você pode ver, disse o grão-vizir, que este leão é tão dócil quanto um escravo dedicado e não faz mal a ninguém. Você passou no teste por ter entrado na sua toca. A prova do seu valor está completa. Agora você é digno de ser o nosso futuro rei. Louvado seja Allah!

O jovem mal podia acreditar no que tinha acontecido. Quando saiu dali, o leão veio junto com ele, andando a seu lado, até que o escravo o levou de volta para a cova.

Houve muita festa no palácio e no dia seguinte as comemorações se estenderam para cada casa na cidade. Seguindo a tradição, o rei distribuiu moedas de ouro e prata para o povo reunido no grande pátio sob o balcão real.

Adil contou a seu pai sobre seu desejo de casar-se com a princesa Perizade e o rei mandou um mensageiro buscá-la.

Para Adil, o tempo que a comitiva demorou para trazer sua amada pareceu-lhe uma eternidade. Ela chegou acompanhada de parentes e amigos, todos vestidos com as mais belas roupas de casamento. Até o fim de seuis dias ele guardou na memória a visão que teve da princesa, cavalgando um cavalo branco árabe, com roupas da mais pura seda e jóias de beleza inigualável.

As festividades do casamento duraram sete dias e sete noites. Assim, eles foram muito felizes e, quando Adil tornou-se rei, fez uma inscrição com letras de ouro no chão de seu quarto de estudos particular que dizia:

Nunca fuja de um leão.

Conto gentilmente cedido por Regina Machado 


\section{O CAVALO MÁGICO}

Era uma vez, não faz muito tempo, um reino cujos habitantes eram extremamente prósperos. Tinham feito toda espécie de descobertas a respeito do crescimento das plantas, da colheita e da conservação de frutos, da manufatura de objetos para vender a outros países, e de muitas outras artes práticas.

Seu soberano era possuidor de uma sabedoria incomum. Incentivava novas descobertas e toda espécie de atividades, pois sabia das vantagens que traziam para seus súditos.

O rei tinha um filho chamado Hoshyar, perito no uso de estranhos aparelhos, e outro chamado Tambal, sonhador, que parecia estar interessado somente naquelas coisas que o povo achava de pouco valor.

De tempos em tempos, o rei Mumkin, assim se chamava o soberano, mandava arautos divulgar que:

"Todos aqueles que tiverem invenções notáveis e artefatos úteis, levem-nos ao palácio, onde serão examinados, de modo que seus inventores sejam devidamente recompensados".

Acontece que naquele país havia dois homens, um ferreiro e um marceneiro, que se rivalizavam em muitas coisas, gostando os dois de construir estranhos artefatos.

Um dia, ao ouvir o anúncio aceitaram competir por um prêmio, para que seu soberano decidisse, de uma vez por todas, a qual deles correspondia maior mérito. Esperavam que essa decisão fosse reconhecida publicamente.

Desse modo, o ferreiro, empregando uma multidão de talentosos especialistas, trabalhou dia e noite na construção de uma poderosa máquina. Para que seus inventos e métodos permanecessem secretos, ele construiu altos muros ao redor de sua oficina.

Ao mesmo tempo, o marceneiro pegava suas ferramentas simples e se dirigira ao bosque, onde, após uma longa e solitária meditação, preparou sua obra prima.

As notícias sobre a competição entre os dois se espalharam. As pessoas achavam que o ferreiro venceria facilmente, pois seus engenhosos trabalhos já eram conhecidos, e, embora de modo geral os produtos do marceneiro fossem admirados seu uso era considerado ocasional e pouco impressionante.

Quando ambos estavam prontos, o rei os recebeu na corte.

O ferreiro tinha fabricado um enorme peixe metálico que, segundo dizia, podia nadar tanto na superfície quanto sob a água. Podia transportar grande quantidade de carga sobre a terra firme, podia escavar túneis e até voar lentamente pelos ares.

A princípio, a corte duvidou que tal maravilha pudesse ter sido construída por um homem, mas quando o ferreiro e seus assistentes fizeram uma demonstração o rei ficou maraviIhado, e proclamou o ferreiro um dos homens mais honoráveis do reino, em uma categoria especial, e honrou-o com o título de Benfeitor da Comunidade.

O príncipe Hoshyar foi encarregado da fabricação dos maravilhosos peixes, e os benefícios do novo invento ficaram ao alcance de toda humanidade.

Todos louvavam o ferreiro, Hoshyar e o benigno e sagaz monarca, a quem tanto amavam. No meio daquele entusiasmo, todos se esqueceram do modesto marceneiro, até que um dia alguém perguntou: 
- Que houve com a competição? Onde está o trabalho do marceneiro? Sabemos que é um homem engenhoso. Talvez tenha fabricado algo útil.

- Como pode haver algo tão útil como os peixes maravilhosos? - perguntou Hoshyar, e muitos, entre os cortesãos e as pessoas do povo, concordaram com ele.

Um dia o rei estava muito aborrecido. Acostumara-se com a novidade dos peixes e com as notícias das maravilhas que executavam.

- Chamem o marceneiro - disse, então. - Gostaria de ver o que ele fez.

O humilde marceneiro, carregando um volume envolto num pano ordinário, entrou na sala do trono. Todos da corte se voltaram, curiosos, para ver o que ele trazia.

Ele desembrulhou o pacote, revelando... um cavalo de madeira. Era finamente talhado, com um complicado desenho esculpido em seu corpo e decorado com pinturas coloridas. Mas era apenas...

- Um simples brinquedo! - explodiu o rei.

- Pai - disse o príncipe Tambal, - perguntemos ao homem para que serve...

- Muito bem - disse o rei. - Para que serve?

- Majestade, é um cavalo mágico - balbuciou o marceneiro. - Não impressiona à vista, mas possui algo semelhante a sentidos internos. Ao contrário do peixe, que deve ser guiado, este cavalo pode interpretar os desejos de seu ginete e levá-lo aonde for necessário que vá.

- Semelhante bobagem só serve para Tambal - murmurou o primeiro-ministro, que estava junto ao rei. - Não pode ter nenhuma utilidade real, se comparado com o maravilhoso peixe.

Triste, o marceneiro preparava-se para partir, quando Tambal disse:

- Pai, deixe-me ficar com o cavalo de madeira.

- Muito bem - disse o rei. - Dêem-lhe o cavalo. Levem o marceneiro e amarrem-no a uma árvore para que compreenda como nosso tempo é valioso. Deixem que contemple a prosperidade que o peixe maravilhoso nos trouxe. Depois de algum tempo talvez o libertemos para que, tendo refletido, pratique o que aprendeu a respeito da verdadeira engenhosidade.

O marceneiro foi conduzido ao seu destino, e o príncipe Tambal retirou-se, levando consigo o cavalo mágico. Em seus aposentos, descobriu que o cavalo tinha vários botões, habilmente disfarçados, entre os desenhos esculpidos. Quando eram girados de determinada forma, o cavalo juntamente com quem o estivesse montando, elevava-se no ar e voava veloz para qualquer lugar imaginado por seu cavaleiro.

Dia após dia, Tambal voou por lugares que nunca tinha visitado antes, e assim chegou a conhecer uma grande quantidade de coisas. Aonde quer que fosse, Tambal levava consigo o cavalo. Um dia, encontrou-se com Hoshyar, que Ihe disse:

- Carregar um cavalo de madeira é uma ocupação própria para alguém como você. Quanto a mim, trabalho para o bem de todos, obedecendo ao desejo do meu coração.

Tambal pensou: "Gostaria de saber qual é o bem de todos e qual seria o desejo do meu coração". Voltando a seus aposentos, sentou-se sobre o cavalo e pensou: "Gostaria de encontrar o desejo do meu coração". Então girou alguns botões no pescoço do cavalo.

Mais veloz do que a luz, o cavalo elevou-se nos ares e levou o príncipe para um reino distante, governado por um rei mago. Normalmente teria levado mil dias viajando para che- 
gar àquele reino.

O rei, cujo nome era Kahana, tinha uma linda filha, chamada Pérola Preciosa, Duri-Karima. Para protegê-la, o rei encerrou-a num palácio que girava nos céus, muito mais alto do que qualquer mortal pudesse alcançar. Tambal viu o reluzente palácio no céu e foi até lá. A princesa e o jovem cavaleiro se conheceram e apaixonaram-se.

- Meu pai jamais permitirá que nos casemos - disse ela, - pois ordenou que eu fosse esposa do filho de outro rei mago que vive a leste daqui, depois do deserto gelado. Prometeu que, quando eu tiver idade suficiente, promoverá a união de ambos os reinos através do meu casamento. Sua vontade jamais foi contrariada com êxito por pessoa alguma.

- Irei vê-lo e tentarei argumentar com ele - respondeu Tambal, montando novamente em seu cavalo mágico.

Acontece que, quando desceu na terra mágica, havia tantas coisas novas e excitantes para ver que ele não foi logo ao palácio. Quando finalmente chegou às suas portas, o tambor da entrada já tocava anunciando a ausência do rei.

Tambal perguntou a um homem que passava quando o rei regressaria.

- Ele foi visitar a filha no Palácio Giratório e costuma passar várias horas com ela - respondeu o homem.

Tambal foi para um lugar afastado, desejou que seu cavalo o levasse aos aposentos do rei e pensando consigo mesmo:

"Eu me aproximarei dele em sua própria casa, pois poderá zangar-se se for procurá-lo no Palácio Giratório sem sua permissão".

Quando se encontrava no quarto do rei, Tambal escondeu-se atrás de umas cortinas e adormeceu.

Enquanto isso, incapaz de guardar seu segredo, a princesa Pérola Preciosa confessou ao pai que, fora visitada por um homem montado num cavalo voador e que, ele queria casarse com ela. Kahana ficou furioso. Pôs sentinelas à volta do Palácio Giratório e voltou aos seus aposentos para refletir sobre o acontecido. Mal entrou em seu quarto um dos mágicos servos mudos que o protegiam apontou para o cavalo de madeira que estava em um canto.

- Aha! - exclamou o mago. - Está em minhas mãos. Vamos observar seu cavalo para saber o que é.

Enquanto ele e os servos examinavam o cavalo, o príncipe conseguiu fugir e esconder-se em outro lugar do palácio.

Depois de girar os botões, bater de leve no cavalo e tentar entender seu funcionamento, o rei parecia confuso.

- Levem isso daqui. Já não tem nenhuma virtude, embora possa ter tido um dia - disse.

- É uma bobagem própria para crianças, e só.

O cavalo foi guardado num armário de coisas velhas.

Então o rei Kahana achou que deveria começar imediatamente os preparativos para o casamento de sua filha, supondo que o fugitivo teria outros poderes ou invenções para conquistá-la. Levou a princesa para seu próprio palácio e enviou uma mensagem ao outro rei mago, pedindo-lhe que o príncipe que ia desposá-la viesse pedir a sua mão.

Enquanto isso tendo escapado do palácio à noite, quando alguns guardas dormiam, o príncipe Tambal decidiu que deveria tentar retornar ao seu país. A busca do desejo do seu 
coração parecia quase impossível agora.

"Mesmo que leve o resto de minha vida, voltarei com tropas para tomar este reino à força", disse consigo mesmo. "Só poderei fazer isso se convencer meu pai de que preciso da sua ajuda para conseguir o desejo do meu coração".

Dizendo isto, partiu. Jamais houve homem tão mal equipado quanto ele para semelhante viagem. Era estrangeiro, viajava a pé e sem provisões, enfrentando dias de calor insuportável e noites geladas, sofrendo debaixo de terríveis tempestades de areia. Não demorou muito para que se visse irremediavelmente perdido no deserto.

Naquela situação, em seu delírio, Tambal começou a culpar a si mesmo, a seu pai, ao rei mago, ao marceneiro, até a princesa e ao próprio cavalo mágico. Algumas vezes pensava que via água a sua frente ou cidades maravilhosas. Em certos momentos se sentia eufórico, em outros muito triste. Houve ocasiões em que imaginou que tivesse companheiros em suas dificuldades, mas ao despertar estava totalmente só. Parecia-lhe que a viagem já durava uma eternidade.

Depois de ter desanimado por várias vezes e começado tudo de novo, viu alguma coisa a sua frente que parecia uma miragem: um jardim cheio de frutas deliciosas, cintilantes, que pareciam convidá-lo a apanhá-las. A princípio Tambal não acreditou. Mas continuou a caminhar e viu que estava realmente atravessando aquele jardim. Apanhou algumas frutas e provou-as com cuidado. Eram deliciosas. Fizeram-no perder o medo, e também a fome e a sede.Quando se viu satisfeito, deitou-se à sombra de uma árvore enorme e hospitaleira, e dormiu.

Ao acordar, sentia-se muito bem, embora alguma coisa parecesse estar errada. Correu até um lago próximo, olhou-se no espelho das águas. Teve diante de si uma horrível visão: a imagem refletida tinha uma longa barba, chifres retorcidos e orelhas enormes. Olhou então para suas mãos e estavam cobertas de pêlos.

Seria um pesadelo? Procurou acordar dando-se beliscões e bofetadas, sem resultado. Descontrolado, fora de si de tanto medo e horror, tomado por acessos de gritos e cansado de tanto chorar, atirou-se no chão.

"Quer viva, quer morra", pensou, "estes frutos malditos me arruinaram definitivamente. Mesmo que eu tivesse o maior exército de todos os tempos, de nada adiantaria. Ninguém se casaria comigo agora, muito menos a princesa Pérola Preciosa. Não posso imaginar um animal sequer que não ficasse apavorado ao ver-me, quanto mais aquela que é o desejo do meu coração".

Nesse instante Tambal perdeu os sentidos. Quando voltou a si já estava escuro. Uma luz se aproximava através do bosque de árvores silenciosas. Medo e esperança debateram-se dentro dele. À medida que a luz se aproximava pode ver o que era. Provinha de uma lanterna em forma de uma estrela brilhante. Era carregada por um homem de barba, que caminhava, se orientando pela luz que projetava ao seu redor. O homem avistou Tambal e disse:

- Meu filho, você foi vítima das influências deste lugar. Se eu não passasse por aqui seria um animal a mais neste jardim encantado, onde há muitos como você. Mas eu posso ajudá-lo.

Tambal se perguntou, se aquele homem não seria um espírito maligno, disfarçado talvez, o dono daquelas árvores malditas. Mas, quando recuperou totalmente a consciência, per- 
cebeu que não tinha nada a perder.

- Ajude-me, pai - disse.

- Se realmente quer o desejo do seu coração - falou o homem, - você deve fixar o seu desejo firmemente em sua mente e esquecer-se do fruto. Depois você deve pegar não os frutos frescos e deliciosos, mas alguns secos que estão debaixo destas árvores. Coma-os e siga o seu destino.

Disse isto e afastou-se.

Enquanto a luz do sábio ia desaparecendo na escuridão, Tambal viu que a Lua surgia e, à luz de seus raios, pôde ver que realmente havia muitas frutas secas sob as árvores. Juntou algumas e comeu-as tão rápido quanto pôde. Pouco a pouco, enquanto observava, os pêlos desapareceram de suas mãos e braços. Os chifres, primeiro, diminuíram, e, depois, desapareceram. Sua barba caiu. Voltara a ser o mesmo.

Naquele momento começavam a surgir as primeiras luzes do dia, e Tambal ouviu o tilintar de campainhas de camelos. Um cortejo vinha atravessando o bosque encantado. Era, sem dúvida, a caravana de algum personagem importante em uma longa viagem.

Enquanto Tambal estava lá, absorto e imóvel, dois cavaleiros se separaram da resplandecente escolta e galoparam até ele.

- Em nome do príncipe, nosso senhor, queremos algumas de suas frutas. Sua alteza celestial está com sede e manifestou o desejo de comer alguns destes estranhos damascos disse um deles.

Tambal, porém, permanecia imóvel, ainda abalado por suas recentes experiências. O próprio príncipe desceu então de seu palanquim e lhe disse:

- Eu sou Jadugarzada, filho do rei mago do leste. Aqui está uma bolsa com moedas de ouro, idiota. Comerei algumas frutas, já que estou com vontade. Tenho pressa e não posso perder tempo, pois vou pedir a mão de minha noiva, Pérola Preciosa, filha de Kahana, rei mago do oeste.

Ao ouvir estas palavras o coração de Tambal se contraiu. Compreendendo, porém, que aquele deveria ser o destino que o sábio o mandara seguir, ofereceu ao príncipe todas as frutas que quisesse comer.

Uma vez satisfeito, o príncipe pôs-se a dormir. Logo lhe começaram a crescer enormes orelhas, chifres e pêlos. Os soldados sacudiram-no, mas o príncipe agiu de maneira estranha. Achava que ele era o normal e os outros os disformes.

Os conselheiros que acompanhavam o cortejo acalmaram o príncipe e travaram uma rápida discussão. Tambal afirmava que nada teria acontecido se o príncipe não tivesse adormecido.

Finalmente, decidiram por Tambal no palanquim para que desempenhasse o papel do príncipe. Jadugarzada, disfarçado de criada, com um véu escondendo-lhe o rosto e os chifres, foi amarrado a um cavalo.

- Talvez recobre o juízo mais tarde - disseram os conselheiros - e continue sendo o nosso príncipe. Tambal se casará com a moça, e depois, logo que seja possível, levaremos todos para o nosso país, a fim de que o rei solucione o problema.

Tambal, à espera do momento oportuno e seguindo o seu destino, aceitou participar da farsa. Quando o cortejo chegou à capital do oeste, o rei foi pessoalmente recebê-los. Tambal foi apresentado à princesa como seu noivo. Surpresa ela quase desmaiou, mas 
Tambal conseguiu sussurrar-Ihe ao ouvido o que acontecera. E foram devidamente casados, em meio a grandes festejos.

Enquanto isso, o infeliz príncipe recobrava um pouco o juízo, mas não a aparência humana, e a escolta ainda o mantinha encoberto.

Logo que os festejos chegaram ao fim, o chefe do cortejo do príncipe de chifres, que tinha estado vigiando Tambal e a princesa bem de perto, apresentou-se à corte e disse:

- Ó justo e glorioso monarca, fonte de sabedoria. De acordo com as declarações de nossos astrólogos e adivinhos, chegou o momento de levar o casal de noivos para a nossa terra, a fim de que se restabeleçam em seu novo lar, nas circunstâncias mais felizes e sob influências propícias.

A princesa, alarmada, olhou para Tambal, pois sabia que Jadugarzada a reclamaria para si logo que se pusessem a caminho, dando fim a Tambal. Mas Tambal murmurou-lhe:

- Não tema. Devemos representar o melhor que pudermos, seguindo o nosso destino. Concorde em partir, mas imponha a condição de que você só viajará levando o cavalo de madeira.

A princípio, o rei mago ficou aborrecido com aquele capricho da filha. Imaginou que ela queria o cavalo porque ele estava ligado ao primeiro pretendente. Mas, o chefe dos ministros do príncipe disse:

- Majestade, não acho que isto seja mais do que um capricho por um brinquedo, que seria normal em qualquer criança. Espero que Ihe dê seu cavalo para que possamos nos por a caminho.

O rei mago concordou e o cortejo pôs-se em marcha. Logo que a escolta se retirou, antes do descanso da primeira noite, o horrendo Jadugarzada tirou o véu e gritou para Tambal:

- Miserável, causador da minha desgraça! Vou amarrar seus pés e suas mãos e o levarei para minha terra como prisioneiro. Quando chegarmos lá, se não me disser como desmanchar este feitiço mandarei esfolá-lo vivo, pouco a pouco. Agora me entregue a princesa Pérola Preciosa.

Tambal protegendo a princesa e, diante do assombrado cortejo, elevando-se pelos ares montado em seu cavalo de madeira, levou consigo Pérola Preciosa.

Em poucos minutos o casal desceu no palácio do rei Mumkin. Contaram-lhe tudo o que Ihes havia acontecido e o rei ficou extremamente feliz por vê-los sãos e salvos.

Imediatamente, ordenou que o infeliz marceneiro fosse libertado, recompensado e aclamado por todas as pessoas do reino.

Quando o rei foi reunir-se a seus antepassados, a princesa Pérola Preciosa e o príncipe Tambal sucederam-Ihe no trono. O príncipe Hoshyar ficou satisfeito também, pois continuava fascinado pelo peixe maravilhoso:

- Estou feliz por vê-los felizes - costumava dizer. - Mas para mim nada é mais compensador do que dedicar-me ao peixe maravilhoso.

Acessado do site: "Instituto Outra História" 


\subsection{ANEXO 3 - BIBLIOGRAFIA}

01. ABD EL-KADER, Emir, Écrits spirituels (trechos Kitâb al-Mawâqif), trad. Michel Chodkiewicz, Éditions du Seuil, 1982.

02. ADDAS, Claude, Expérience et doctrine de l'amour

03. ADDAS, Claude, La quête du soufre rouge, Gallimard, 1989.

04. AL-ADAWIYYA, Rabi'a, Dichos y Poemas, Ediciones Dervish International, Buenos Aires, 1986.

05. AL-BISTÂMî, Abû Yazid, Les Dits de Bistâmî (Shatahât), Fayard, 1989.

06. AL-SULAMI, Futuwah - Tratado de Caballeria Sufi, Paidos, Barcelona, 1991.

07. ALMOND, lan, Sufism and Deconstruction, Routledge, 2004.

08. ASÍN PALACIOS, Miguel, El Islam Cristianizado, Hiperión, Madrid, 3a. edição, 1990.

09. ASÍN PALACIOS, Miguel, La Escatologia Musulmana en la Divina Comédia, Hiperión, Madrid, 4a. edição, 1884.

10. ATTAR, Farid-ud-Din', A Linguagem dos Pássaros, Attar Editorial, São Paulo, 1987.

11. ATTAR, Farid-ud-Din', Le Livre des Secrets, Les Deux Océans, Paris, 1985.

12. ATTAR, Farid-ud-Din', Le Mémorial des Saints, Éd. du Seuil, 1976.

13. BÂ, Amadou Hampâté, A noção de pessoa entre os fula e os bambara, in Revista Thot, n. 64, 1977.

14. BARALT, Luce Lopez, Un kama sutra espanhol, Siruela, 1992.

15. BAUMAN, Zygmunt, Identidade, Jorge Zahar, Rio de Janeiro, 2005.

16. BORGES, Jorge Luis, "O Etnógrafo", in Elogio da Sombra, Editora Globo, 1977.

17. BURCKHARDT, Titus, Arte Sagrada no Oriente e no Ocidente, Attar Editorial, São Paulo, 2004.

18. BURCKHARDT, Titus, Clé Spirituelle de L'Astrologie Musulmane, d'après Mohyiddîn Ibn 'Arabî, Archè Milano, 1974.

19. BURCKHARDT, Titus, Introduction aux Doctrines Ésotériques de I'Islam, Dervy-Livres, Paris, 1969.

20. BURCKHARDT, Titus, La Civilización Hispano-Árabe, Alianza Editorial, Madrid, 1977.

21. CHAUÍ, Marilena, Experiência do Pensamento, Martins Fontes, 2002.

22. CHAUÍ, Marilena, Laços do Desejo, in Desejo, Cia das Letras, 1990.

23. CHAUÍ, Marilena, Brasil: mito fundador e sociedade autoritária, Ed. Fund. Perseu Abramo, São Paulo, 2000. 
24. CHITTICK, William, "La Unidad del Ser", In: Postdata, Asociación de la Prensa de Murcia, 1995.

25. CHITTICK, William, The Sufi Path of Knowledge, State University of New York Press, Albany, 1989.

26. CHODKIEWICZ, Michel, Le Sceau des Saints, Gallimard, 1986.

27. CHODKIEWICZ, Michel, The Banner of Praise

28. CHODKIEWICZ, Michel, Un Océan sans rivage, Éditions du Seuil, 1992.

29. DERRIDA, Jacques, A Farmácia de Platão, lluminuras, 2005.

30. DESCOMBES, V., Le même et l'autre, Minuit, 1979.

31. Dictionnaire Encyclopédique de I'Islam, Bordas, Paris, 1991.

32. DOSSE, François, Histoire du Structuralisme, Éd. la Découverte, 2 vols., Paris, 1991.

33. DUQUE-ESTRADA, Paulo Cesar, Às Margens, Puc-Rio, 2002.

34. DUQUE-ESTRADA, Paulo Cesar, Espectros de Derrida, Puc-Rio, 2002.

35. FOUCAULT, Michel, Surveiller et Punir, Gallimard, 1975.

36. FOUCAULT, Michel, Les mots et les choses, Gallimard,

37. GARAUDY, Roger, "Promessas do Islam", Nova Fronteira, 1988.

38. GUÉNON, René, Le regne de la quantité et les signes des temps, Gallimard, 1945.

39. HABERMAS, Jürgen, Mudança Estrutural da Espera Pública, Tempo Brasileiro, 2003.

40. HADDOCK-LOBO, Rafael, Derrida e o Labirinto de Inscrições, Zouk, 2008.

41. IBN 'ARABî, Muhyiddîn, El secreto de los nombres de Dios (Kasf al-ma'nà 'an sirr asmâ' Allâh al-husnà), trad. Pablo Beneito, Ed. Regional de Murcia, España, 1996.

42. IBN 'ARABÎ, Muhyiddîn, Guia Espiritual, Editora Regional de Murcia, 1990.

43. IBN 'ARABÎ, Muhyiddîn, L'Alchimie du Bonheur Parfait, Berg International, Paris, 1981.

44. IBN 'ARABî, Muhyiddîn, L'Interprète des Désirs (Turjumân al-Ashwâq), trad. M. Gloton, Albin Michel, 1996.

45. IBN 'ARABÎ, Muhyiddîn, La Parure des Abdal (Hilyatu- I-Abdâl), trad. Michel Vâlsan, Les Éditions de l'Oeuvre, Paris, 1992.

46. IBN 'ARABî, Muhyiddîn, La Production des Cercles (Kitâb inshâ' ad-dawâ'ir al-ihâtiyya), trad. Paul Fenton e Maurice Gloton, Éditions de l'Éclat, Paris, 1996.

47. IBN 'ARABî, Muhyiddîn, La Sagesse des Prophètes (trechos Fusus al-Hikam), trad. Titus Burckhardt, Albin Michel, 1974.

48. IBN 'ARABÎ, Muhyiddîn, Las Contemplaciones de los Misterios (Mashâhid al-Asrâr), trad. Suad Hakim e Pablo Beneito, Editora Regional de Murcia, España, 1994.

49. IBN 'ARABî, Muhyiddîn, Le Dévoilement des Effets du Voyage (Kitâb al-isfâr 'na natâ'ij 
al-asfâr), trad. Denis Gril, Éditions de l'Éclat, France, 1994.

50. IBN 'ARABÎ, Muhyiddîn, Le Livre de I'Extinction dans la Contemplation (Kitâbu-I-Fanâ'i fî-I-Mushâhada), trad. Michel Vâlsan, Les Éditions de l'Oeuvre, Paris, 1984.

51. IBN 'ARABÎ, Muhyiddîn, Le Livre des Chatons des Sagesses (Kitâb Fusûs al-Hikam), trad. Charles-André Gilis, 2 vols., Les Éditions Al-Bouraq, Beirute, Líbano, 1998.

52. IBN 'ARABî, Muhyiddîn, Les Illuminations de la Mecque (trechos do Futûhât alMakkiyya), trad. Chodkiewicz e outros, Albin Michel, Paris, 1997.

53. IBN 'ARABÎ, Muhyiddîn, Meccan Revelations, Pir Press, Nova York, 2002.

54. IBN 'ARABÎ, Muhyiddîn, Tarjumân al-Ashwâq, trad. R. Nicholson, Royal Asiatic Society, Londres, $2^{\mathrm{a}}$ ed., 1978.

55. IBN 'ARABÎ, Muhyiddîn, The Seven Days of the Heart - prayers for the nights and days of the week, trad. de Pablo Beneito e Stephen Hirtenstein, Anqa Publishing, Oxford, 2000.

56. IBN 'ARABî, Muhyiddîn, Traité de l'Amour, Albin Michel, Paris, 1986.

57. IBN 'ARABÎ, Muhyiddîn, Viaje al Senor del Poder, Ed. Sirio, Málaga, Espanha, 1986.

58. Jîlî, Abd Al-Karîm, De l'Homme Universel - Extraits du livre al-Insân al-Kâmil, trad. Titus Burckhardt, Dervy-Livres, Paris, 1975.

59. KHATAMI, Muhammad, Diálogo entre civilizações, Attar Editorial, 2006.

60. LACAN, Jacques, Écrits, Ed. du Seuil, Paris, 1966

61. LEITE, Sylvia, O Simbolismo dos Padrões Geométricos da Arte Is/âmica, Ateliê Ed., 2007.

62. LINGS, Martin, El Secreto de Shakespeare, Ed. de la Tradicion Unanime, 1988.

63. LINGS, Martin, A Sufi Saint of the Twentieth Century - Shaikh Ahmad al-Alawî, The Islamic Texts Society, $3^{\text {rd }}$ ed., 1993, Cambridge.

64. LINGS, Martin, Muhammad, Hiperión, Madrid, 1989.

65. MACHADO, Beatriz, Sentidos do Caleidoscópio, Humanitas, 2004.

66. MACHADO, Regina, Acordais, Difusão Cultural do Livro, 2004.

67. MACHADO, Regina, Nasrudin, Cia. das Letrinhas, 2001.

68. MATOS, Olgária, Adivinhas do Tempo, Hucitec, São Paulo, 2008.

69. MERLEAU-PONTY, Maurice, A Linguagem indireta e as vozes do silêncio.

70. MERLEAU-PONTY, Maurice, A Prosa do Mundo, Cosac \& Naify, 2002.

71. MERLEAU-PONTY, Maurice, Fenomenologia da Percepção, Martins Fontes, 1999.

72. MERLEAU-PONTY, Maurice, O Visivel e o Invisivel, Perspectiva, 1984.

73. MERNISSI, Fatima, El Harém Político, Ediciones del oriente y del mediterraneo.

74. NIZÂMî, La Historia de Layla y Majnûm, Olañeta Editor, Barcelona, 1991 
75. PATTO, Maria Helena, Mutações do Cativeiro, Edusp, 2004.

76. PONSOYE, Pierre, L'Islam y el Grial, Olañeta Editor, Barcelona, 1984.

77. PRADO, Adélia, Poesia Reunida, Siciliano, São Paulo, 1991.

78. ROSA, João Guimarães, Obras Completas, Vol. II, Ed. Nova Aguilar, Rio de Janeiro, 1995

79. RUMI, Jalaluddin, Delicious Laughter, trad. Coleman Barks, Maypop Books, 1990.

80. RUMI, Jalaluddin, Masnavi, Edições Dervish, Rio de Janeiro, 1992.

81. RUMI, Jalaluddin, Poemas Místicos, Attar Editorial, São Paulo, 1996.

82. RUMI, Unseen Rain, quatrains of Rumi, by John Moyne and Coleman Barks, 1986.

83. SCHUON, Frithjof, Comprendre I'Islam, Éditions du Seuil, Paris, 1976.

84. SCHUON, Frithjof, Regards sur les Mondes Anciens, Éditions Traditionelles, Paris, 1980.

85. SCHUON, Frithjof, Sur les Traces de la Religion Pérenne, Le Courier du Livre, Paris, 1982.

86. SENNETT, Richard, Carne e Pedra, Bestbolso, 2008.

87. SHAH, Idries, Aprender a Aprender, Paidós, 1988.

88. SHAH, Idries, Caravane de Rêves, Ed. du Rocher, 1989.

89. SHAH, Idries, Dervish Tales.

90. SHAH, Idries, El Monasterio Mágico, Paidós, 1991.

91. SHAH, Idries, Los Sufies, Luis de Caralt Editor, Barcelona, 1975.

92. SHAH, Idries, Sages d'Orient, Ed. du Rocher, 1988.

93. SHAH, Idries, The way of the Sufi, Penguin 1990.

94. SHAH, Idries, A Perfumed Scorpion, The Octagon Press, London, 2000.

95. SHAH, Idries, Un Escorpión Perfumado, Kairós, Barcelona, 1992.

96. SHAH, Idries, Una Gacela Velada, Herder, Barcelona, 1997.

97. SHAH, Saira, A filha do contador de histórias - Uma jornada aos confins do Afeganistão, Cia das Letras, São Paulo, 2003.

98. SHAKESPEARE, William, Romeu e Julieta, in Obra Completa, Ed. Nova Aguilar, Rio de Janeiro, 1989.

99. SHAKESPEARE, William, The Illustrated Stratford Shakespeare, London, 1984.

100. VALSÂN, Michel, Remarques occasionnelles sur Jeanne D'Arc et Charles VII, in Études Traditionnelles, nos. 412-413.

101. VERNET, Juan, "Lo que Europa debe al Islam de España", El Acantilado, Barcelona, 1999.

102. VITRAY-MEYEROVITCH, El Canto del Sol, Olañeta Editor, Palma de Mallorca, 1997. 
103. VITRAY-MEYEROVITCH, Eva de, Anthologie du Soufisme, Albin Michel, 1995.

104. VITRAY-MEYEROVITCH, Eva de, Le Chant du Soleil, La Table Ronde, Paris, 1993.

105. YAHIA, Osman, Histoire et Classification de l'oeuvre d'Ibn 'Arabî, Institut Français de Damas, 2 vols., 1964. 